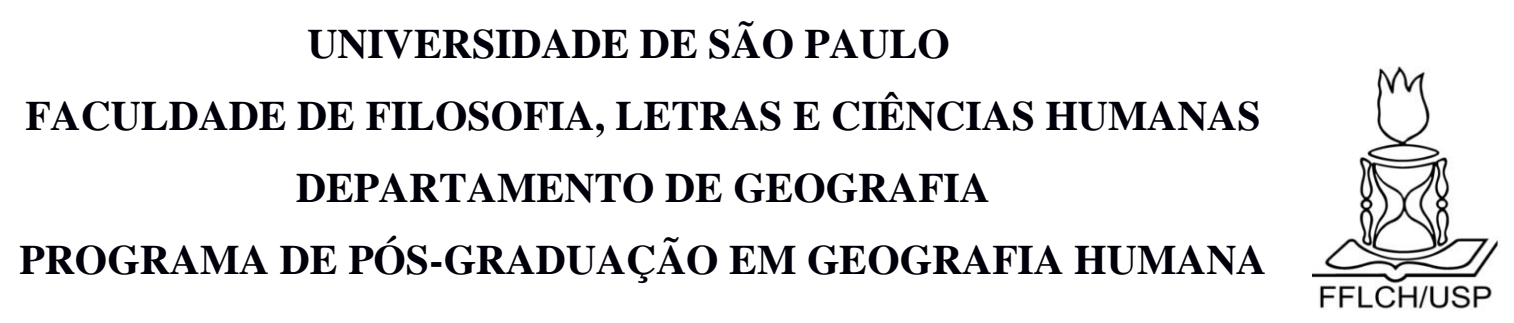

ISMANE DESROSIERS

Haiti: da desigualdade social às desigualdades socioespaciais na metrópole de Porto Príncipe (versão corrigida) 
UNIVERSIDADE DE SÃO PAULO

FACULDADE DE FILOSOFIA, LETRAS E CIÊNCIAS HUMANAS

DEPARTAMENTO DE GEOGRAFIA

PROGRAMA DE PÓS-GRADUAÇÃO EM GEOGRAFIA HUMANA

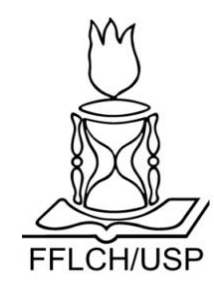

ISMANE DESROSIERS

Haiti: da desigualdade social às desigualdades socioespaciais na metrópole de Porto Príncipe

Dissertação de Mestrado apresentada junto ao Programa de PósGraduação em Geografia Humana da Faculdade de Filosofia, Letras e Ciências Humanas da Universidade de São Paulo (FFLCH-USP), como requisito à obtenção do título de Mestre em Geografia.

Orientador: Prof. Dr. Francisco Capuano Scarlato Área de Concentração: Geografia Humana

Linha de Pesquisa: Geografia da cidade e do Urbano Agência Financiadora: $\mathrm{CNPq}$

SÃO PAULO 
FOLHA DE APROVAÇÃO

\section{Haiti: da desigualdade social às desigualdades socioespaciais na metrópole de Porto Príncipe}

\section{ISMANE DESROSIERS}

Dissertação de Mestrado apresentada junto ao Programa de PósGraduação em Geografia Humana da Faculdade de Filosofia, Letras e Ciências Humanas da Universidade de São Paulo (FFLCH-USP), como requisito à obtenção do título de Mestre em Geografia.

Aprovado em: 20/01/2020.

Banca Examinadora

Prof. Dr. Francisco Capuano Scarlato, Presidente (FFLCH-USP)

Prof. Dr. André Roberto Martin (FFLCH-USP)

Prof. Dr. Vicente Eudes Lemos Alves (UNICAMP)

Prof ${ }^{\mathrm{a}}$. Dr ${ }^{\mathrm{a}}$. Bernadete Aparecida Caprioglio de Castro (UNESP)

SÃo PAULO

2020 
Autorizo a reprodução e divulgação total ou parcial deste trabalho, por qualquer meio convencional ou eletrônico, para fins de estudo e pesquisa, desde que citada a fonte.

Catalogação na Publicação

Serviço de Biblioteca e Documentação

Faculdade de Filosofia, Letras e Ciências Humanas da Universidade de São Paulo

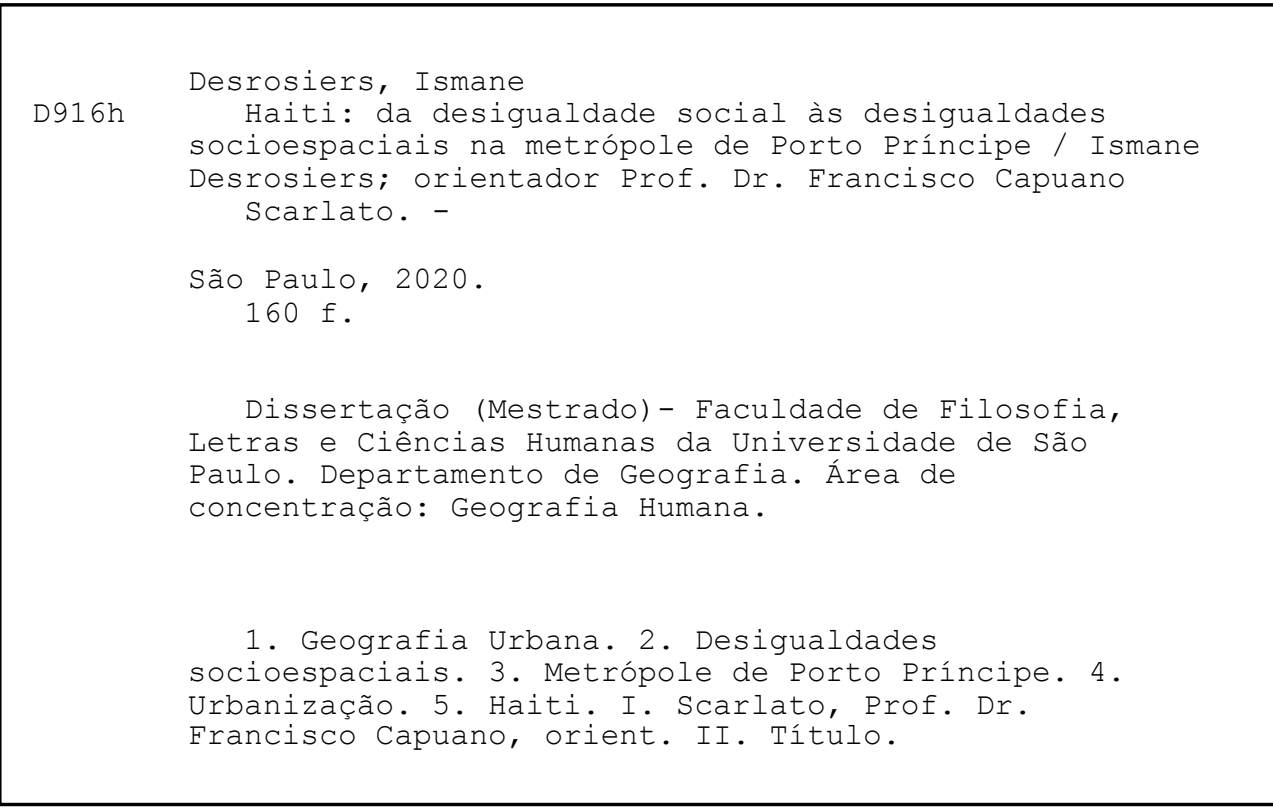




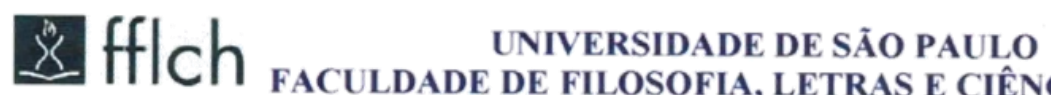 FACULDADE DE FILOSOFIA, LETRAS E CIÊNCIAS HUMANAS \\ ENTREGA DO EXEMPLAR CORRIGIDO DA DISSERTACÃO/TESE \\ Termo de Ciência e Concordância do (a) orientador (a)}

Nome do (a) aluno (a): Ismane Desrosiers

Data da defesa: 20 de janeiro de 2020

Nome do Prof. (a) orientador (a): Francisco Capuano Scarlato

Nos termos da legislação vigente, declaro ESTAR CIENTE do conteúdo deste EXEMPLAR

CORRIGIDO elaborado em atenção às sugestões dos membros da comissão Julgadora na sessão de defesa do trabalho, manifestando-me plenamente favorável ao seu encaminhamento e publicação no

\section{$\underline{\text { Portal Digital de Teses da USP }}$}

São Paulo, 20 de março de 2020

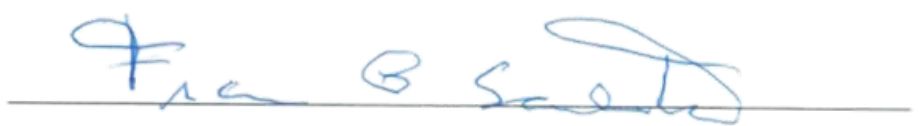

Assinatura do (a) orientador (a) 


\section{AGRADECIMENTOS}

Primeiramente agradeço meu orientador, o Prof. Dr. Francisco Capuano Scarlato, pelo privilégio de ser seu orientando, pela confiança colocada em mim, acreditando na minha capacidade intelectual de aprendizagem e desenvolvimento do projeto de pesquisa que apresentei desde o começo. Agradeço, pela paciência, pelas orientações e por outros serviços acadêmicos prestados por mim ao longo do curso.

Aos Professores Alfredo Anselmo, Ana Fani Alessandri Carlos, Glória da Anunciação Alves e Isabel Aparecida Pinto Alvarez pelas suas contribuições na minha formação acadêmica no Programa de Pós-Graduação em Geografia Humana da USP.

Às Professoras Glória Alves e Isabel Alvarez pelas críticas e valiosas sugestões no Exame de Qualificação. Aos Professores André Roberto Martin, Vicente Eudes Lemos Alves e Bernadete Aparecida Caprioglio de Castro. Aos funcionários da Secretaria de Pós-Graduação em Geografia Humana da USP, especialmente, à Rosângela pela sua paciência e sua compreensão.

Ao Conselho Nacional de Desenvolvimento Cientifico e Tecnológico (CNPq) pelo apoio financeiro. $\mathrm{N}^{\circ}$ do processo: 170022/2018-8.

Ao Professor Vicente Eudes Lemos Alves, do Departamento de Geografia da Universidade Estadual de Campinas (UNICAMP), pela oportunidade de ser seu orientando na Iniciação Científica (2015) e no Trabalho de Conclusão de Curso (2016).

À minha mãe Francina (“Ismane, estou com saudades" "Eu também, mãe!”) e meus irmãos Philemond, Marlene, Emanise e Edmond. A Geografia nos separa há mais de 8 anos, mas saibam que amo vocês e o Haiti.

À Jocelyne, técnica do Serviço de Planejamento Urbano do MTPTC, ao Rwendy, técnico do Escritório Técnico de Edifício do MTPTC, ao Anilus, técnico da EPPLS, ao Arquiteto Odnell, responsável da Divisão habitacional da UCLBP, pelas informações e conversas que tivermos durante as visitas técnicas nessas instituições e aos entrevistados na ocasião do trabalho de campo em Porto Príncipe, Haiti em 2017.

Agradeço enormemente a todas as pessoas queridas que acompanharam a minha trajetória acadêmica aqui no Brasil de perto ou de longe. Aquelas pessoas que sempre passaram para mim as energias positivas. Por exemplo, Maurício, Iago, Josephine, Wagner, Melissa, Fabian (colombiano), Francisco (mexicano), Julia, Igor, Frantz, Fabien, Josué, Dieumettre, Jean Renel, Desbas, Gineth, Alexendre, Rodrigo, Evandro, Ralph, Leo, Paul, Felipe, Roger, Jeferson, Mikael, Juliano, Marcos, Guilherme, Tuwile, Katiana, Daniel. Agradecimento especial ao Piero, Fábio, Rafael, Thiago e Julio. 


\section{SUMÁRIO}

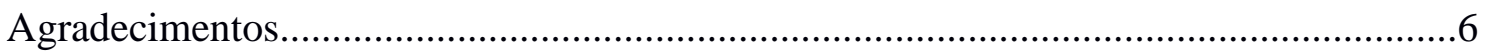

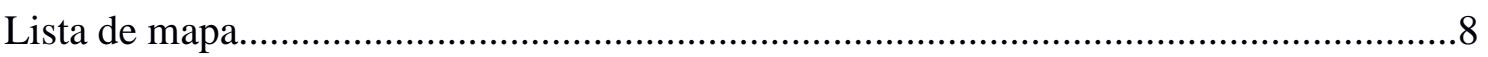

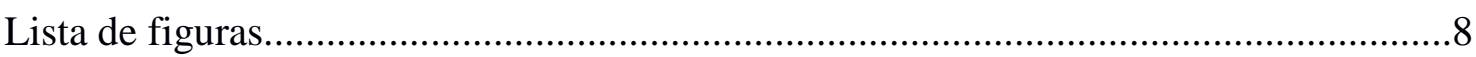

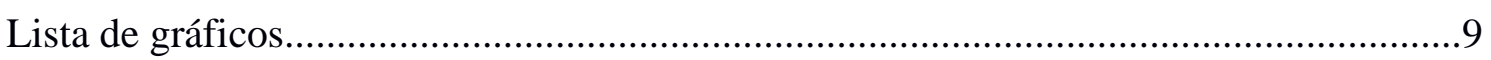

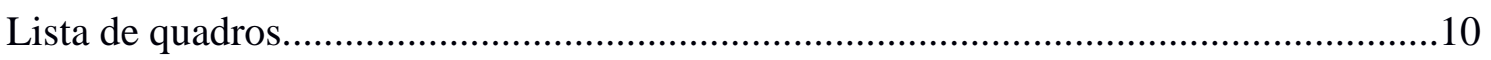

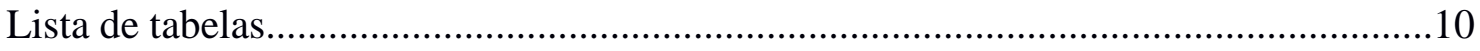

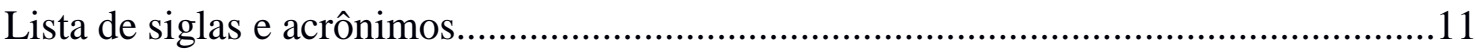

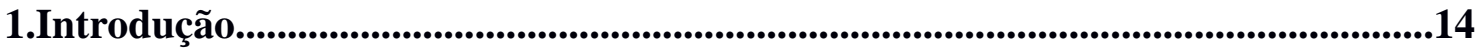

1.1 Análise teórica da noção da desigualdade social / socioespacial no espaço urbano da cidade na história do desenvolvimento do capitalismo.................................14

1.2 Abordagem metodológica e técnicas da pesquisa...........................................21

2. A dinâmica socioespacial na cidade de Porto Príncipe no pós-terremoto de

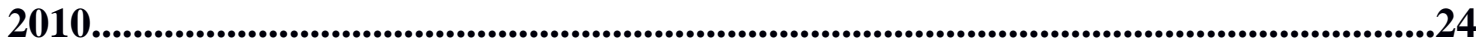

2.1 Consequências socioeconômicas e infraestruturais da tragédia na cidade..........24

2.2 Planos e financiamentos de reconstrução de Porto Príncipe após a catástrofe...33

2.3 Avaliação da implementação do projeto de requalificação urbana do centro de Porto Príncipe: Cidade Administrativa de 2012 .............................................................45

3. A urbanização do Haiti e centralização em Porto Príncipe de 1980 até

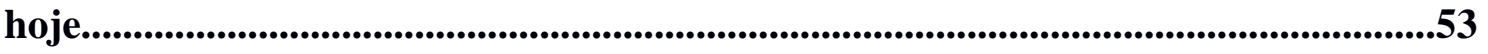

3.1 Processo da expansão urbana da cidade de Porto Príncipe.................................53

3.2 Transporte e mobilidade urbana em Porto Príncipe ...........................................71

3.3 Desigualdades socioespaciais na cidade a partir da questão habitacional...........81

3.4 Análise da economia urbana em Porto Príncipe..................................................95

4. A formação socioespacial do Haiti......................................................................114

4.1 Sucessão e coexistência do fenômeno da desigualdade no Haiti: análise da

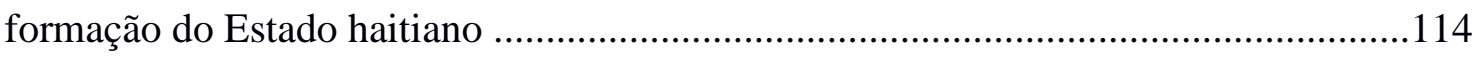

4.2 Raízes das desigualdades sociais no Haiti......................................................129

4.3 Efeitos da corrupção na dinâmica das desigualdades no Haiti............................136

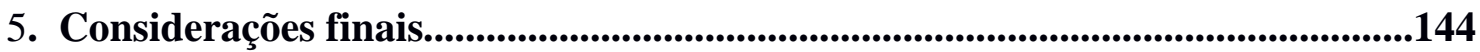

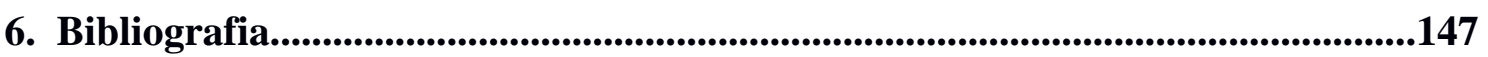

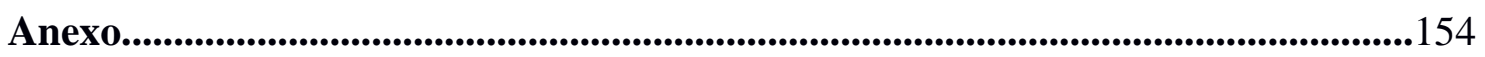




\section{LISTA DE MAPAS}

Mapa 1- Localização geográfica do Haiti e da área de estudo.....................................18

Mapa 2- Vista global de destruição em Porto Príncipe no pós-terremoto de 2010.........26

Mapa 3- Mobilidade espacial da população no pós-terremoto de 2010.........................27

Mapa 4- Processo de metropolização de Porto Príncipe após 2010 ................................32

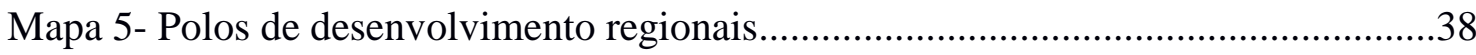

Mapa 6- A expansão urbana da cidade de Porto Príncipe entre 1980 a 2012 .................66

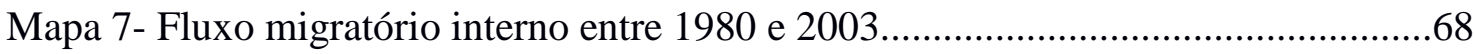

Mapa 8- Mapa metropolitano de transporte ferroviário em 1930.................................73

Mapa 9- Os grandes eixos de circulação na RMPP......................................................78

Mapa 10- Distribuição da população na RMPP em 1985............................................83

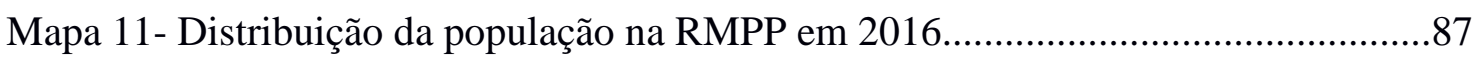

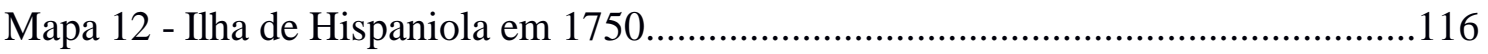

Mapa 13 - Rotas comerciais e o comércio triangular no século XVI e XVIII............................117

Mapa 14 - Independências dos países da América Latina e do Caribe...........................123

\section{LISTA DE FIGURAS}

Figura 1 - Vista aérea da ocupação do espaço de Canaan em 2015................................31

Figura 2 - Projeto de requalificação urbana do centro de Porto Príncipe da Fundação

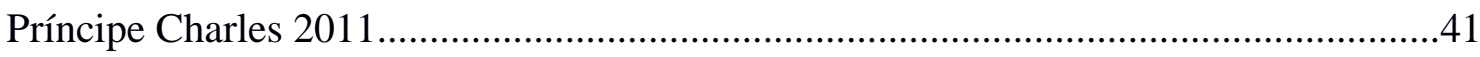

Figura 3 - Projeto de requalificação urbana: Cidade Administrativa .............................43

Figura 4 - Vista parcial do centro de Porto Príncipe em 2017........................................45

Figura 5 - Renovação e ampliação do Quiosque Occide Janty.....................................46

Figura 6 - Corte Suprema de Porto Príncipe.................................................................47

Figura 7 - Ministério do Interior e das Coletividades Territoriais................................48

Figura 8 - Corte Superior de Contas e do Contencioso Administrativo ........................ 49

Figura 9 - Ministério da Economia e Finanças.................................................................50

Figura 10 - Ministério do Comércio e da Indústria........................................................ 51

Figura 11 - Obras de requalificação urbana da Exposição de 1949................................55

Figura 12 - Centro de Porto Príncipe e o Théâtre de Verdure em 1949..........................57

Figura 13 - Meio de transporte em Porto Príncipe no final do século XIX e início do

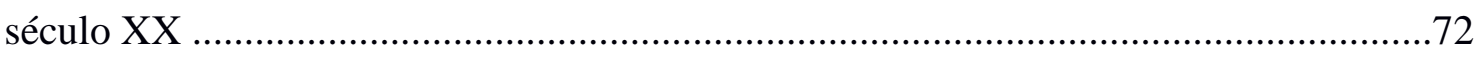

Figura 14 - Os meios de transporte coletivo interurbano na RMPP em 2017.............. 75 
Figura 15 - Tipos de habitação nos bairros considerados pobres na RMPP. . .88

Figura 16 - Centro do município de Petion-ville em 2018 ............................................90

Figura 17 - Tipos de habitação em bairros considerados de classe média na RMPP...92

Figura 18 - Mercado municipal de Porto Príncipe em 2011 ....................................... 108

Figura 19 - Sede central da companhia DIGICEL S.A em Porto Príncipe.....................109

Figura 20 - Sede central da companhia NATCOM S.A em Porto Príncipe .................110

Figura 21 - Parque Industrial Metropolitano...............................................................111

Figura 22 - Projeto do Parque Industrial de Digneron.................................................112

Figura 23 - Manifestação contra a corrupção em Porto Príncipe em 2018....................143

\section{LISTA DE GRÁFICOS}

Gráfico 1 - Fluxo de retorno em Porto Príncipe entre 2010 e $2011 .$. 28

Gráfico 2 - Contribuição de países e organismos na reconstrução do Haiti de 2010 a

2011

Gráfico 3 - Beneficiários dos fundos para reconstrução do Haiti entre 2010 a 2011...35

Gráfico 4 - Crescimento da população haitiana entre 1804 a 2010................................59

Gráfico 5 - Tendência demográfica da população haitiana de 1950 a 2012..................61

Gráfico 6 - Origem dos moradores entrevistados na cidade de Porto Príncipe............... 64

Gráfico 7 - População total entrevistada na cidade de Porto Príncipe.............................64

Gráfico 8 - Crescimento populacional da RMPP de 1950 a 2005................................. 65

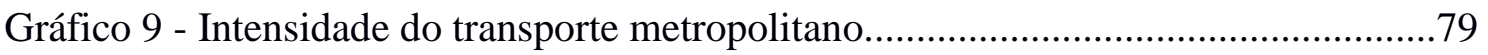

Gráfico 10 - Grau de instrução de moradores entrevistados em bairros considerados

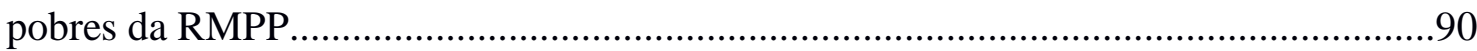

Gráfico 11 - Profissão de moradores entrevistados bairros considerados pobres da RMPP.

Gráfico 12 - Grau de instrução de moradores entrevistados em bairros considerados de classe média da RMPP .93

Gráfico 13 - Profissão de moradores entrevistados em bairros considerados de classe média da RMPP.

Gráfico 14 - Dívida externa do Haiti em milhões de dólares de 1970 até 2006. .97

Gráfico 15 - Produção e importação de arroz proveniente dos EUA de 1985 a 1999.... 98

Gráfico 16 - Tendência e a composição setorial do PIB haitiano entre 1800 a 2009....100

Gráfico 17 - Pirâmide etária da população haitiana em 2012 .......................................102

Gráfico 18 - Taxa de crescimento da população total e ativa entre 1990 e 2015..........104 
Gráfico 19 - Distribuição de renda no Haiti em 2006..................................................133

Gráfico 20 - Distribuição de renda no Haiti entre 2011 e 2012 _....................................134

Gráfico 21 - Setores envolvidos em casos de corrupção no Haiti .................................139

\section{LISTA DE QUADROS}

Quadro 1 - Consequências socioeconômicas de eventos naturais no Haiti......................25

Quadro 2 - Dinâmica da desigualdade no Haiti 1986/1987/ e 1999/2000......................132

Quadro 3 - Índice de Percepção de Corrupção no Haiti de 2002 a 2014.......................137

\section{LISTA DE TABELAS}

Tabela 1 - Distribuição da população por região, superfície e densidade em 2010........62

Tabela 2 - Dados demográficos dos municípios da RMPP em 2009................................. 63 


\section{LISTA DE SIGLAS E ACRÔNIMOS}

ALC América Latina e do Caribe

ADIH Associação das Indústrias do Haiti

ACR Comitê Americano para os Refugiados

BIRD Banco Internacional para Reconstrução e Desenvolvimento

BID Banco Interamericano de Desenvolvimento

BM Banco Mundial

BRH Banco da República do Haiti

CHPD Centro Haitiano de Pesquisa em Desenvolvimento

CFRC Comitê de Facilitação para Reconstrução do Centro

CSC/CA Corte Supremo de Contas e de Contencioso Administrativo

FFLCH Faculdade de Filosofia, Letras e Ciências Humanas

FMI Fundo Monetário Internacional

IHSI Instituto Haitiano de Estatística e de Informática

IPC Indício de Percepção da Corrupção

IBGE Instituto Brasileiro de Geografia e de Estatística

USP Universidade de São Paulo

UNICAMP Universidade Estadual de Campinas

UnB Universidade de Brasília

UNFPA Fundo de População das Nações Unidas

UEH Universidade do Estado do Haiti

ULCC Unidade de Luta Contra a Corrupção

IDH Índice de Desenvolvimento Humano

CIAT Comitê Interministerial do Planejamento Territorial

CNIGS Centro Nacional de Informações GeoEspacial

CNSA Conselho Nacional de Segurança Alimentar

CEPAL Comissão Econômica para a América Latina e o Caribe

DSNCRP Document de Stratégie Nationale pour la Croissance et la Réduction de la Pauvreté

MICT Ministério do Interior e das Coletividades Territoriais

MCI Ministério do Comércio e da Indústria

MTPTC Ministério das Obras Públicas, Comunicação e Transporte

MOSOSAH Movimento de Solidariedade com os Sem Abrigo do Haiti 
MINUSTHA Missão das Nações Unidas para Estabilização do Haiti

OMC Organização Mundial do Comércio

ONU Organização das Nações Unidas

ONG Organizações Não Governamentais

OIM Organização Internacional para as Migrações

SIG Sistema de Informação Geográfica

SPU Serviço de Planejamento Urbano

MPCE Ministério do Planejamento e Cooperação Externa

EPPLS Empresa Pública de Promoção de Habitações Sociais

ECVH Enquete sobre as Condições de Vida no Haiti

EMMUS Enquete de Mortalidade, Morbidade e Utilização de Serviços

ECVMAS Enquete sobre as Condições de Vida das Famílias Após o Sismo

EEEI Enquete sobre o Emprego e da Economia Informal

UCLBP Unidade de Construção de habitação e Edifícios Públicos

UN-HABITAT Programa das Nações Unidas para os Assentamentos Humanos

RNDH Relatório de Desenvolvimento Nacional do Haiti

PNUD Programa das Nações Unidas para o Desenvolvimento

PDNA Post Disaster Needs Assessment

PIB Produto Interior Bruto

IDM Indicadores de Desenvolvimento Mundial

RMPP Região Metropolitana de Porto Príncipe

PARDH Plano de Ação para Recuperação e do Desenvolvimento do Haiti 


\section{RESUMO}

DESROSIERS, Ismane. Haiti: da desigualdade social às desigualdades socioespaciais na metrópole de Porto Príncipe, 2020. Dissertação de Mestrado Faculdade de Filosofia, Letras e Ciências Humanas da Universidade de São Paulo (FFLCH-USP).

Este trabalho trata da dinâmica das desigualdades sociais no Haiti, com enfoque nas desigualdades socioespaciais originadas pela urbanização do país evidentes em Porto Príncipe na atualidade. Levando em conta essa realidade, esta pesquisa tem como objetivo analisar essas desigualdades na metrópole de Porto Príncipe, em que os grupos sociais menos favorecidos na estrutura urbana se revelam por meio das formas de distribuição de renda, das infraestruturas, equipamentos urbanos existentes e em virtude da segregação residencial entre os diferentes bairros da cidade. Nesse sentido, verificamos como as novas espacialidades, associadas ao ritmo de urbanização, engendram as formas e os conteúdos que expressam as desigualdades socioespaciais na cidade marcadas pela disparidade das condições de vida da população urbana. Portanto, a pesquisa busca evidenciar a ampliação dessa situação na metrópole no contexto pósterremoto de 2010. O procedimento metodológico que contempla a pesquisa articula a teoria da formação socioespacial proposta por Milton Santos (1979), bem como o uso de fontes bibliográficas que abarcam discussões sobre a cidade e sobre o urbano, além do trabalho de campo baseado em entrevistas e em aplicação de questionários.

Palavras-chave: Haiti, Urbanização, Metrópole Porto de Príncipe, Habitação, Desigualdades socioespaciais. 


\begin{abstract}
DESROSIERS, Ismane. Haiti: from social inequality to socio-spatial inequalities in the Port-au-Prince metropolis, 20120. Master's Dissertation - Faculty of Philosophy, Letters and Human Sciences, University of São Paulo (FFLCH-USP).
\end{abstract}

This paper deals with the dynamics of social inequalities in Haiti, focusing on the socio-spatial inequalities originated by the urbanization of the country evident in Port-au-Prince today. Considering this reality, this research aims to analyze these inequalities in the metropolis of Port-au-Prince, where the least favored social groups in the urban structure reveal themselves through the forms of income distribution, infrastructures, existing urban facilities and by virtue of residential segregation between the different neighborhoods of the city. In this sense, we verify how the new spatialities, associated with the pace of urbanization, engender the forms and contents that express the socio-spatial inequalities in the city marked by the disparity of living conditions of the urban population. Therefore, the research seeks to highlight the expansion of this situation in the metropolis in the post-earthquake context of 2010. The methodological procedure that contemplates the research articulates the theory of socio-spatial formation proposed by Milton Santos (1979), as well as the use of bibliographic sources that cover discussions about the city and the urban, as well as fieldwork based on interviews and questionnaires.

Keywords: Haiti, Urbanization, Port-au-Prince Metropolis, Housing, Socio-spatial Inequalities. 


\section{INTRODUÇÃO}

\subsection{ANÁliSE TEÓRICA DA NOÇÃO DA DESIGUALDADE SOCIAL E SOCIOESPACIAL DURANTE O DESENVOLVIMENTO DO CAPITALISMO}

Esta pesquisa procura contribuir para o debate que evolve temas e problemas relacionados à Geografia Urbana. Nesse sentido, propomos uma discussão e uma análise sobre a desigualdade social no Haiti, com enfoque nas desigualdades socioespaciais na metrópole de Porto Príncipe. Levamos em consideração as transformações espaciais vistas por meio da urbanização e fatores que levam à formação dos bairros precários na cidade. Tudo isso com diversos problemas sociais, tais como: a escassez de moradia de qualidade, de infraestrutura, de saúde, de educação e de mobilidade urbana; que são marcas evidentes das desigualdades estruturantes na metrópole ao longo das transformações históricas.

Segundo Milton Santos (2010, p. 38), uma metrópole pode ser brevemente definida como o organismo urbano onde existe uma complexidade de funções, capazes de atender a todas as formas de necessidades da população urbana e nacional ou regional. Para o geógrafo brasileiro esta última seria realmente uma metrópole completa. $\mathrm{O}$ autor avança no seu argumento sinalizando que a realidade do mundo em desenvolvimento pode, também, permitir falar de metrópoles incompletas. Essas metrópoles, de acordo com Santos (2010), são grandes organismos urbanos, em que a maioria dos serviços essenciais está presente, mas onde fatores econômicos específicos impedem que se fabriquem bens ou se instalem certos serviços, reclamados por uma parcela da população que está em crescimento. O autor cita, por exemplo, a ausência de indústrias de base como uma dessas carências (SANTOS, 2010, p. 38). Esse é um caso tipo da metrópole de Porto Príncipe no meio da urbanização do Haiti.

Nesta pesquisa, trabalhamos analiticamente com a noção de desigualdade social nas perspectivas marxistas presentes em O Capital (1988), que relacionam o problema das desigualdades com as teorias de classes sociais. Entretanto, acreditamos que no Haiti "não existe classe social", pois, segundo Marx (1988), a estrutura de classes no modo de produção capitalista está vinculada a sua concepção materialista da história, em que há uma relação fundamental dos produtores diretos da riqueza social, os proletários, e os apropriadores do excedente econômico, os donos dos meios de produção. Segundo Marx, para que haja classe é necessário haver a consciência de classe. 
A consciência de classe é o elo que permite a passagem da classe "em si", agrupamento com interesses, objetivos latentes, à classe "para si", grupo de poder que tende a organizar-se para o conflito ou luta política com interesses objetivos claros e declarados. Contudo, a consciência de classe não surge espontaneamente a partir de uma situação de classe. De acordo com Marx (1988) são necessárias duas fases consecutivas para que ocorra o desenvolvimento da consciência de classe. Na primeira, uma classe social respeita outra classe devido à sua posição na organização socioeconômica. $\mathrm{Na}$ segunda fase, a classe toma consciência de si mesma, de seus interesses e de sua missão histórica, como um grupo de ação política com efetivo papel nas lutas sociais ao contribuir para as mudanças sociais e para o desenvolvimento da sociedade. Veremos neste estudo que não ocorrem as duas fases da consciência de classe as quais o autor se referencia na sociedade haitiana.

Com o desenvolvimento do capitalismo nos Estados Unidos da América (EUA) no século XX, foi fundada a Escola sociológica de Chicago, voltada sobre os estudos de sociologia urbana, a estrutura social urbana e a formação, em sentido lato senso, das cidades. A sociologia urbana possuía pressupostos, em seu início, evolucionistas (GRAFMEYER, 2000). Mais tarde incorpora elementos da filosofia e da psicologia, que causaram impactos diretos na Geografia, por exemplo. Assim, a noção de segregação socioespacial aparece pela primeira vez nos primeiros estudos e análises de sociologia urbana nos EUA. Podemos arrolar alguns dos seus estudiosos: Robert Ezra Park (1864-1944); Ernest Watson Burgess (1886-1966); Roderick Duncan McKenzie (1885-1940), William Thomas (1863-1947), Frederic Thrasher (1892-1970), Louis Wirth (1897-1952) e Everett Hughes (1897-1983) (GRAFMEYER, 2000). Todavia, a proposta teórica da Escola sociológica de Chicago encontrou barreiras em sua formação e desenvolvimento interno, uma vez que novas contribuições filosóficas e teóricas expressas junto à compreensão do espaço urbano emergem e superam epistemologicamente, e respeitando a historicidade das camadas de saber, o primeiro movimento desse campo de estudos urbanos.

A partir das décadas de 1960 e de 1970 a linguagem teórica fundamentada no marxismo se constitui como uma alternativa ao paradigma $^{1}$ (KUHN, 1997, p. 13) da

1 Segundo Kuhn (1997, p. 13), os paradigmas são realizações científicas universalmente reconhecidas que, durante algum tempo, fornece problemas e soluções modelares para uma comunidade de praticantes de uma ciência T, S. A estrutura das revoluções científicas. 5. ed. São Paulo: Ed. Perspectiva S.A, 1997. 
ecologia humana ${ }^{2}$ da chamada Escola de Chicago junto à compreensão do fenômeno urbano. Teve origem na França essa nova conjuntura de reflexões face à interpretação das cidades e modulou-se a partir da atualização do materialismo dialético e histórico. Seus principais teóricos são: Pierre Georges (1970, 1975, 1978), Yves Lacoste (1968, 1985), Henri Lefebvre (1973, 1991, 2001, 2002), Manuel Castells (1972, 1983), Milton Santos $(1979,1978,2008)$ e David Harvey (1980). Desse modo, vários estudos sobre a cidade são fundamentados no marxismo enquanto instrumental teórico-metodológico, sobretudo no contexto da pós Segunda Guerra Mundial. Nesse período, a economia capitalista passa por transformações sem precedentes em sua história, atingindo, principalmente, o conjunto das variantes econômicas próprias do considerado "capitalismo avançado", sobretudo englobando regiões da Europa, da América do Norte e do Japão. O fenômeno da urbanização conhece uma aceleração denominada por Lefebvre como duplo movimento de implosão-explosão ${ }^{3}$ (LEFEVBRE, 2004, p. 26). Nessa mesma movimentação há o processo de concentração e de dispersão (SANTOS, 1979, p. 129), o que torna o fenômeno da desigualdade socioespacial na cidade compassado com as consequências do capitalismo.

Haiti: da desigualdade social às desigualdades socioespaciais na metrópole de Porto Príncipe é o nosso estudo de caso diante desse preâmbulo teórico-prático que arquitetamos. A relevância dessa pesquisa se articula com uma preocupação geográfica e sociopolítica minha, quer dizer, por uma tentativa de iluminar a comunidade nacional sobre as condições de vida na cidade. Para isso, partimos do movimento progressivoregressivo (LEFEBVRE, 1971, p. 129) como aporte metodológico para entender o entendimento, com ressonâncias na atualidade da ideia marxista da passagem da “consciência de si” para uma "consciência para si" 4 (MARX 1988). Tudo isso, diante

2 Para Pack (1864-1944), o conceito de ecologia humana serviu de base para o estudo do comportamento humano, tendo como referência a posição dos indivíduos no meio social urbano.

$3 \mathrm{O}$ crescimento industrial sobrepõe-se ao crescimento das trocas comerciais. E aqui estão incluídas as trocas entre os indivíduos e as trocas de produtos. A compra e a venda, a mercadoria e o mercado, o dinheiro e o capital parecem varrer os obstáculos. Isso leva, de acordo com Lefebvre (2004), a um momento crítico, caracterizado pela implosão-explosão: uma enorme concentração (de pessoas, atividades, riquezas e pensamentos), ao lado de uma imensa explosão, com a projeção de fragmentos múltiplos e disjuntos (periferias, subúrbios etc.).

4 Segundo Marx (1988), a ideia “de si” e "para si” é uma consciência que por sua própria natureza dialética produz e reproduz aspectos da realidade. Para esses atores [...] a consciência é o que caracteriza o ser social como um ser pensante sobre sua realidade e que age intencionalmente para modificá-la a partir da passagem da consciência "'em si" (individual) para uma consciência "para si'" (coletiva). Portanto, apoiado nas reflexões desses autores, podemos dizer que a consciência tem papel ativo na construção de uma nova realidade social de uma nação em busca de bem-estar coletivo. 
do esteio socioeconômico e geográfico referente às condições de vida da população na metrópole. Isso pode ser visualizado, por exemplo, a partir do nosso trabalho de campo, em que os relatos dos moradores entrevistados tornam-se vestígios, ícones, indícios ou evidências do todo dessa perspectiva de trabalho. Articulamos, assim, os estudos já realizados sobre a cidade. Por exemplo, os de Devauges (1954), Anglade (1974; 1982), Bazabas (1997), Holly (1999), Godard (1985, 1994), Louis (2009), Lucien (2010).

Todavia, esses autores não abordam, especificamente, a problemática da dinâmica das desigualdades sociais no Haiti com destaque sobre as desigualdades socioespaciais na metrópole Porto Príncipe, no sentido sincrônico e diacrônico (SANTOS, 1996, p. $159)^{5}$ inerente à formação socioespacial do Haiti na virada do século XVIII para o século XIX, vista a partir de uma perspectiva de longa duração (BRAUDEL, 1969). Cabe salientar que a nossa perspectiva foge de uma visada evolucionista, propondo uma análise dialética que busca desvendar as diferentes formas das desigualdades inerentes ao capitalismo no tempo e no espaço, principalmente na periferia deste sistema evidenciada no Haiti. Dito de outro modo, o plano geral da nossa pesquisa parte de problemas do presente.

Nessa direção, começamos o capítulo introdutório fazendo uma análise teórica da noção da desigualdade social e desigualdade socioespacial no espaço urbano da cidade no decorrer da história do desenvolvimento do capitalismo. No segundo capítulo, abordamos a dinâmica socioespacial na cidade de Porto Príncipe no contexto pósterremoto de 2010. Contudo, o nosso estudo sobre a problemática das desigualdades socioespaciais abrange, principalmente de 1980 até hoje, tendo como ponto de partida a urbanização acelerada observada no Haiti. O terceiro capítulo discute a urbanização do Haiti bem como, a centralização em Porto Príncipe de 1980 até o presente momento. E, por fim, no quarto capítulo, buscamos evidenciar a situação descrita tanto no primeiro, como no segundo capítulo, a partir de uma perspectiva histórica do fenômeno da desigualdade social própria à formação socioespacial do Haiti e à história do desenvolvimento do capitalismo, ou seja, um dos fundamentos do referido sistema.

A cidade de Porto Príncipe apesar de ser uma metrópole incompleta no nosso entendimento mantém relações socioeconômicas com outras cidades metropolitanas; promovendo, inclusive, relações recíprocas caracterizadas por fluxos de pessoas, de

5 Segundo Santos (1996, p. 159-160) a ideia de sincronia e de diacronia constitui uma dinâmica no sentido do movimento no espaço e no tempo com estrutura social que evidencia a coexistência entre o passado e o presente da sociedade. 
bens, de informações e de capital que eles trocam entre si. A cidade de Porto Príncipe é o centro em torno do qual desenvolvem essas cidades e irradia as demais cidades regionais do país. Isso significa que a metrópole de Porto Príncipe se beneficia de uma localização geográfica excepcional e estratégica (HOLLY, 1999) desde a sua fundação, em 1749, que a posiciona enquanto "nó" de ligação entre a parte norte e a parte sul do país como mostrado no mapa (B) a seguir.

\section{Mapa 1 - A localização geográfica do Haiti e da área de estudo}
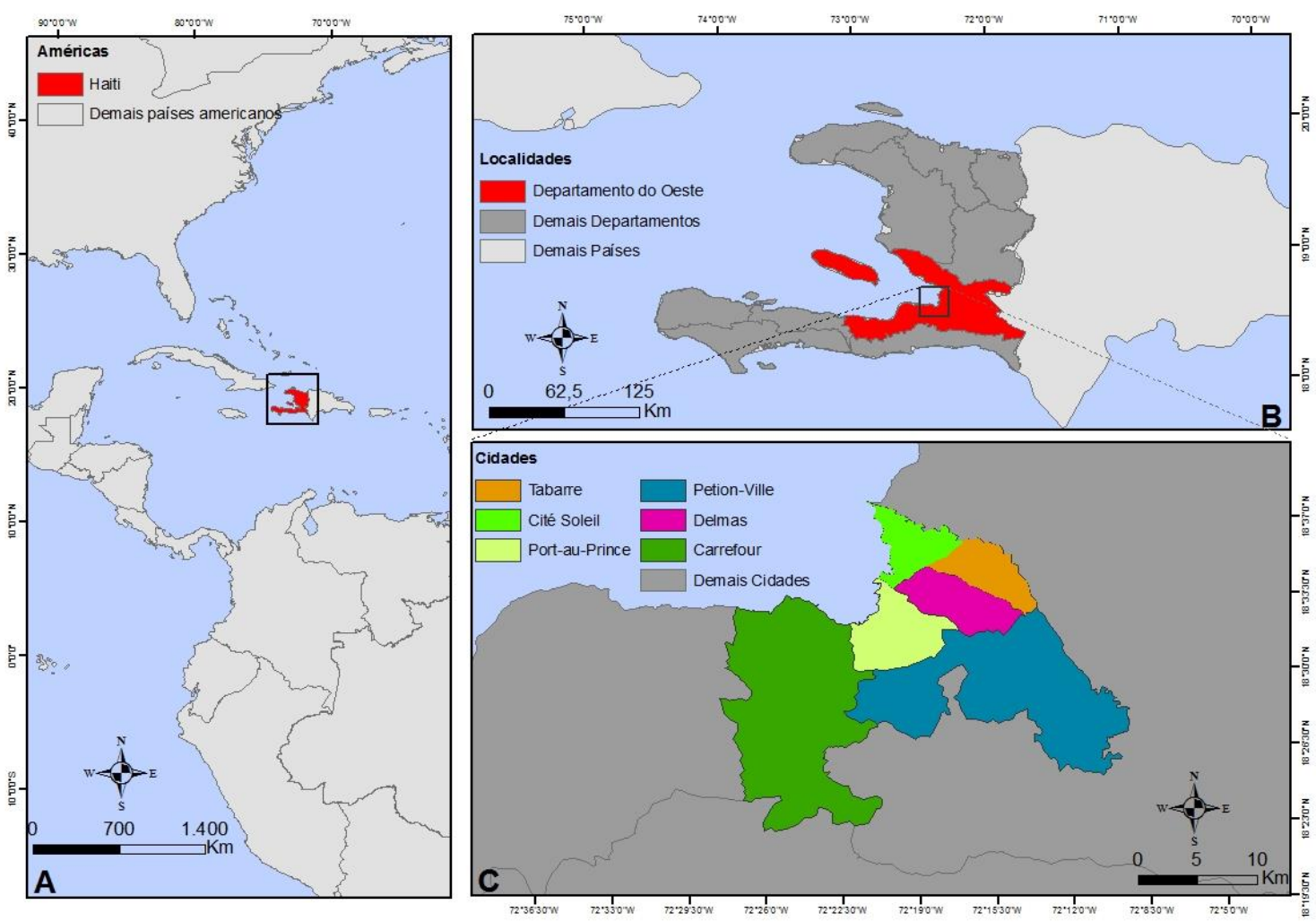

Fonte: CNIGS, CNSA, jun. 2016. IBGE. Mapa A: Localização do Haiti em relação às Américas; Mapa B: Maiores divisões territoriais do Haiti; Mapa C: Região metropolitana de Porto Príncipe. Organização das informações: Ismane Desrosiers. Elaboração: Thiago Esteves Nogueira, 2018.

O Haiti é um dos países mais desiguais da América; essa desigualdade se apresenta por meio da urbanização de sua metrópole, Porto Príncipe, onde as desigualdades socioespaciais são evidentes em termos de distribuição de infraestruturas e equipamentos em diferentes bairros no espaço urbano da cidade. Diante desse fato, algumas questões são importantes a serem feitas: quais são as raízes dessas desigualdades? Em que sentido elas impactam na distribuição espacial da população em bairros de poder aquisitivo alto e baixo junto ao espaço urbano da metrópole?

Para responder esses questionamentos, consideramos necessária a construção de um pensamento que reconhece e analisa criticamente as raízes das desigualdades sociais 
no Haiti no sentido diacrônico e sincrônico desse fenômeno social, que são perceptíveis na contemporaneidade sobre forma de desigualdades socioespaciais no espaço urbano da cidade de Porto Príncipe. Ademais, essa pesquisa parte da problemática (hipótese) de que as desigualdades socioespaciais na cidade são resultantes das contradições do sistema capitalista em sua periferia que se revela em Porto Príncipe através de processos históricos, políticos, econômicos, externos e internos, a própria formação socioespacial do Haiti enquanto totalidade ${ }^{6}$ (SANTOS, 1979, p. 10) em movimento. Consideramos, nesse sentido, as camadas temporais, de modo a reconhecer a relevância desses processos históricos e sua relação com a realidade urbana atual da metrópole no contexto pós-terremoto de 2010 e do país como o todo em termos socioeconômicos.

Para nossa investigação acerca da dinâmica das desigualdades socioespaciais na metrópole de Porto Príncipe, recorremos aos trabalhos do geógrafo brasileiro Milton Santos, em especial no que se refere à proposta teórica e metodológica da Formação Socioespacial. Esse eixo de análise é apresentado pelo autor em 1979, então derivado da teoria da formação econômica e social de Marx (1988). Ele se apoia nos fundamentos da economia política inscritas no prefácio do livro $O$ Capital. Essa categoria de análise marxista toma uma nova dimensão nos escritos miltonianos, sobretudo no que se refere às relações socioespaciais que é válida para a compreensão das instâncias próprias da noção de espaço (SANTOS, 1979). Formação socioespacial se refere à análise da concretude de uma sociedade compreendendo seu desenvolvimento, sua situação atual, sua mudança histórica e suas relações. Esse método se baseia na dialética teoria e prática, especialmente na análise da ligação entre os processos do passado e do presente.

Seguindo a concepção teórico-metodológica que orienta essa pesquisa, também nos baseamos nas análises e reflexões acerca da compreensão da cidade e do espaço urbano a partir de contribuições destes autores: Harvey (1980), Santos (1979, 1990, 1996, 1997, 2005, 2008), Corrêa, (1989, 1997, 2000, 2005), Carlos (1994, 1992), Lefebvre (1971, 1973, 1991, 2001, 2002, 2004, 2008), Godard (1983, 1991, 1994), Bazabas (1997), Corvington (1991), Holly (1999), Anglade (1974, 1982, 1990). Os

6 Articulamos o conceito de totalidade a partir das reflexões de Milton Santos que aponta que o espaço reproduz a totalidade através das transformações determinadas pela sociedade, modos de produção, distribuição da população, entre outras necessidades, desempenham funções evolutivas na formação econômica e social, influencia na sua construção e também é influenciado nas demais estruturas de modo que torna um componente fundamental da totalidade social e de seus movimentos (SANTOS, 1979). 
trabalhos desses autores ganham importância na dimensão teórica, pois discutem a urbanização, a produção do espaço urbano e as desigualdades socioespaciais. A contribuição desses teóricos localiza-se na economia categorial que mobilizam na discussão de uma teoria social crítica. Além disso, eles acionam problemáticas urbanas de acordo com o nível de renda, de qualidade de habitação e de condições de vida urbana de modo geral. Dialogamos com esses autores para esclarecer as linhas do pensamento a serem percorridas ao longo do trabalho, tendo como os principais conceitos a desigualdade social e socioespacial, seguindo o paradigma da Geografia Crítica fundamentada no materialismo histórico e dialético.

\subsection{Abordagem metodológica e técnicas da pesquisa}

Do ponto de vista metodológico, nossa pesquisa se modula a partir de uma gama variada de fontes de informações. Os materiais são de fontes secundárias e primárias. Esses foram selecionados e analisados em face da problemática geral da pesquisa, sendo dividido em duas partes que se coadunam, mas não são justapostas:

1) fizemos uma pesquisa bibliográfica e documental por meio de livros, artigos, arquivos, dissertações e teses correlatos e pertinentes ao desenvolvimento do trabalho. Tudo isso para analisar a produção histórico-geográfica do nosso recorte espaço temporal para a compreensão das dinâmicas que contribuem para as desigualdades na região em Porto Príncipe na contemporaneidade. Tais materiais são obtidos nas bibliotecas digitais e nos acervos das bibliotecas da Universidade Estadual de Campinas (UNICAMP), da Universidade de São Paulo (USP) e da Universidade Estadual do Haiti (UEH) e no Instituto Haitiano de Estatística e de Informática (IHSI).

No que diz respeito ao processo de urbanização os dados são obtidos a partir do IHSI, do Comitê Interministerial do Planejamento Territorial (CIAT), do Ministério do Interior e das Coletividades Territoriais (MICT), do Ministério das Obras Públicas Comunicação e Transporte via o Serviço de Planejamento Urbano (SPU-MTPTC) e do Ministério do Planejamento e Cooperação Externa (MPCE). Dados sobre os programas de habitação no Haiti foram conseguidos através da Empresa Pública de Promoção de Habitações Sociais (EPPLS) e da Unidade de Construção de Habitação e Edifícios Públicos (UCLBP), do Ministério das Obras Públicas Transporte e Comunicação (MTPTC) e do Programa das Nações Unidas para os Assentamentos Humanos (UNHABITAT-Haiti). Este trabalho se realizou durante visitas técnicas nessas autarquias no Haiti em 2017. 
2) Para o desenvolvimento desta pesquisa tomamos como esteio o nosso trabalho de campo $^{7}$, que foi realizado entre janeiro e fevereiro de 2017 na região metropolitana de Porto Príncipe, abrangendo desde os bairros considerados precários até aqueles com poder aquisitivo maior. Esse foi um dos procedimentos metodológicos mais importantes em nosso trabalho, pois permite ancorar o nosso conhecimento empírico junto à problemática geral da pesquisa. Tudo isso considerando os procedimentos de observação das áreas da cidade onde muitas habitações foram destruídas ou danificadas devido à passagem do terremoto de 2010. Objetiva-se a compreensão da realidade das desigualdades socioespaciais em diferentes bairros da região metropolitana de Porto Príncipe; evidenciando questões relativas, por exemplo, ao transporte público coletivo e ao acesso aos serviços básicos públicos de consumo. Além disso, para uma maior sustentação da pesquisa são realizadas entrevistas aleatoriamente com alguns moradores em certos bairros da metrópole de Porto Príncipe, sendo essas constituídas de perguntas abertas e fechadas com os seguintes indicadores: acesso à água, saneamento básico, tratamento de esgoto, emprego, renda per capita, grau de instrução, profissão, transporte público e as condições de habitação antes e depois do terremoto de 2010. Essas informações são disponíveis de forma mais detalhada no anexo da pesquisa.

Porém, partirmos da ideia de que qualquer metodologia de pesquisa baseada na investigação de campo admite algum grau de limitação. Nesse sentido, devemos mencionar que este trabalho de campo foi conduzido em uma amostra de 112 chefes de famílias que, por razões éticas e científicas da pesquisa, optamos por ocultar seus nomes para salvaguardar a dignidade e o direito desses sujeitos, também, importantes que nos fornecem informações para o desenvolvimento desta pesquisa. Dessa maneira, esse número não leva em conta uma amostra maior, para se estender a vários outros bairros da região metropolitana de Porto Príncipe, devido às restrições financeiras, o período que passamos no Haiti, Porto Príncipe, em particular. Essas razões, portanto, nos

7 O roteiro do Trabalho de Campo foi montado sob a orientação da Prof ${ }^{\mathrm{a}}$. Dr ${ }^{\mathrm{a}}$. Maria Tereza Duarte Paes, do Departamento de Geografia e do Programa de Pós-Graduação em Geografia do Instituto de Geociências (IG) da Universidade Estadual de Campinas (UNICAMP). Além de uma carta de autorização a ser apresentada nas instituições haitianas que nos permitiram de pesquisar nos documentos e bases de dados das Secretarias, Bibliotecas, Institutos, Jornais, Revistas e Arquivos de órgãos públicos, da Prefeitura Municipal de Porto Príncipe, a fim de apoiar nossa pesquisa. Cabe salientar que eu já era graduado em Geografia pela Unicamp querendo aderir ao Programa de Pós-Graduação em Geografia da mesma instituição, porém não consegui no primeiro semestre de 2017. Mas consegui ingressar no segundo semestre do mesmo ano, no Programa de Pós-Graduação em Geografia Humana da Universidade de São Paulo (USP). Meu orientador, neste Programa, após sua avaliação disse que dados levantados no Trabalho de Campo poderiam ser aproveitados no presente trabalho. 
impede de visitar mais bairros na sua região metropolitana com o propósito de recolher mais informações. Embora, as condições de vida sejam análogas, sobretudo, nos bairros desfavorecidos e, apesar das limitações desta abordagem metodológica, esta última, no entanto, é o único caminho que nos permite de tentar alcançar os objetivos perseguidos.

Além das entrevistas realizamos, também, levantamento de imagens, o que nos fez ter um contato direto e imagético com a dinâmica do espaço urbano na metrópole Porto Príncipe. Obtivemos informações sobre a problemática habitacional junto à Prefeitura Municipal de Porto Príncipe por meio de representantes de movimentos sociais urbanos, como no caso do Movimento de Solidariedade com os Sem Abrigo do Haiti (MOSOSAH) ${ }^{8}$. Tudo isso numa visita técnica em 2017. Consideramos que o procedimento metodológico tem papel ativo na realização de uma pesquisa, evidentemente através de uma postura crítica que implica no levantamento das informações e na articulação com a problematização acerca daquilo que se encontra durante o desenvolvimento da pesquisa.

Desvelamos as contradições e confrontamos os dados coletados e as produções científicas com a questão de pesquisa e as hipóteses levantadas. Por isso, em termos de análise de informações e de tratamento de dados que são coletados no trabalha de campo, utilizamos softwares, tais como: Excel 2010, ArcGis como técnica de georeferenciamento (Sistema de Informação Geográfica, SIG) e o emprego de Google Earth, que serviram como elementos indispensáveis para os cruzamentos das informações e dados, e a síntese desses últimos. Portanto, os resultados dessas informações e dados tratados do trabalho de campo, são apresentados sob forma de mapas, figuras, tabelas, gráficos e quadros no corpo do trabalho.

8 Movimento criado na contemporaneidade, após o terremoto de 2010, com o objetivo de contribuir para a melhoria das condições habitacionais da população de baixa renda no Haiti. O motivo que levou à criação deste movimento surgiu nos primeiros abrigos organizados em Porto Príncipe imediatamente após o terremoto que danificou ou destruiu totalmente muitas habitações na região metropolitana de Porto Príncipe, entre outras regiões do país. Os fundadores desta associação são cidadãos haitianos, alguns foram acomodados nestes abrigos, outros ajudaram a organizar a associação, portanto todos são envolvidos por uma melhoria na questão habitacional e na reconstrução do país como o todo. 


\section{A DINÂMICA SOCIOESPACIAL NA CIDADE DE PORTO PRÍNCIPE PÓS- TERREMOTO DE 2010}

\subsection{As consequências socioeconômicas e infraestruturais do terremoto de $\mathbf{2 0 1 0}$}

Este segundo capítulo da Dissertação apresenta a situação atual do Haiti, especialmente a reconstrução da metrópole de Porto Príncipe no contexto pós-terremoto de 2010. Nesse sentido, descrevemos as consequências socioeconômicas e infraestruturais do desastre na cidade, desvendando como o impacto desse terremoto contribui no aumento das desigualdades socioespaciais na metrópole. Além disso, apresentaremos e discutiremos os planos e financiamentos de reconstrução do Haiti com enfoque nos projetos de requalificação urbana de Porto Príncipe, em particular, o projeto Cidade Administrativa iniciado em 2012. Trata-se da segunda maior intervenção urbana na cidade desde a Exposição Universal do bicentenário de Porto Príncipe, em 1949. E, por fim, faremos uma avaliação da implementação desse projeto a fim de apresentar a morfologia urbana da cidade na atualidade.

O Haiti está geograficamente localizado em uma área de risco para furacões e terremotos. Desse modo, de todos os países insulares do Caribe, o Haiti é o país com o maior índice de vulnerabilidade. Ademais, as desigualdades sociais historicamente construídas aumentam ainda mais a vulnerabilidade da população haitiana diante esses fenômenos naturais. Nesse sentido, em 12 de janeiro de 2010, o Haiti (principalmente, a cidade de Porto Príncipe) foi devastada por um terremoto de magnitude 7.3 na Escala de Rister. O epicentro desse evento ${ }^{9}$ (SANTOS, 1996, p. 147) foi localizado a cerca de 25 $\mathrm{km}$ a sudoeste da capital do país onde passa uma falha tectônica que atravessa a cidade que contava, em 2009, com cerca de 2,3 milhões de habitantes (IHSI, 2009). Esse evento deixou mais de 220.000 mortes, cerca de 300.000 feridos, 1,5 milhão de desabrigados, e 660.000 pessoas fugiram da cidade ${ }^{10}$. Por conseguinte, o impacto desse terremoto aumenta os desafios que a cidade enfrenta historicamente no seu desenvolvimento, pois a metrópole abriga quase um terço da população haitiana, onde ocorre mais de $80 \%$ das atividades econômicas. Com efeito, nos últimos 15 anos, cinco eventos naturais evidenciam a fragilidade do país. É obvio, pela sua localização geográfica, que o Haiti é sujeito aos eventos naturais, mas por que o país é tão

9 De acordo com Santos (1996), a noção de evento é o próprio movimento da natureza, isto é, da manifestação diversificada da energia natural. Para o autor, é assim que a natureza muda sua própria dinâmica.

10 Disponível em https://haiti. humanitarianresponse.info. Acesso em 12 de fev. de 2019. 
vulnerável aos fenômenos naturais em relação aos seus países vizinhos como Cuba, República Dominicana e Jamaica? De que maneira, essa vulnerabilidade, sobretudo, socioeconômica está enraizada no próprio processo de formação socioespacial do país?

Quadro 1 - Consequências socioeconômicas de eventos naturais no Haiti

\begin{tabular}{|l|l|l|l|}
\hline Evento natural & PIB afetado & População afetada & $\mathbf{N}^{\circ}$ de mortos \\
\hline Furacão Jeanne, 2004 & $7 \%$ & 300000 & 5000 \\
\hline Furacões Dean e Noel, 2007 & $2 \%$ & 194000 & 330 \\
\hline $\begin{array}{l}\text { Furacões Fay, Gustav, } \\
\text { Hanna e Ike, 2008 }\end{array}$ & $15 \%$ & 1000000 & 800 \\
\hline Terremoto, 2010 & $120 \%$ & 2000000 & 222000 \\
\hline Furacão Matthew, 2016 & $20 \%$ & 2.100000 & 546 \\
\hline Total & $\mathbf{1 6 4 \%}$ & $\mathbf{5 5 9 4 0 0 0}$ & $\mathbf{2 2 9 1 7 6}$ \\
\hline
\end{tabular}

Fonte: HAIT, PDNA, 2010. Adaptação: Ismane Desrosiers, 2019.

O quadro 1 faz ver as consequências socioeconômicas de fenômenos naturais que ocorreram no Haiti nos últimos quinze (15) anos afetando a economia e a população sem esquecer as infraestruturas do país. Nesse período, o evento natural mais devastador é o terremoto de 2010, pois, segundo o estudo da avaliação das necessidades após o desastre, The Post Disaster Needs Assessment (HAITI, PDNA) ${ }^{11}$, cerca de 105.000 casas foram completamente destruídas e mais de 208.000 danificadas. Mais de 1.300 instituições de ensino, mais de 50 hospitais e centros de saúde foram destruídos ou danificados. Além disso, o evento causou a destruição dos símbolos do poder de Estado, tais como o palácio presidencial, o parlamento, a sede do poder judiciário, os tribunais e os edifícios da administração pública. Isso fez com que, antes do terremoto de 2010, o Haiti que já era considerado como o país mais pobre da América acumulasse danos e prejuízos estimados em US\$ 10 bilhões, o que equivalia a pouco mais de $120 \%$ do produto interno bruto do país em 2009 (HAITI, PDNA, 2010). Isso exacerbou ainda mais os problemas socioeconômicos e infraestruturais do país, principalmente, na região metropolitana de Porto Príncipe, a parte mais afetada devido à maior concentração populacional, dos investimentos e as infraestruturas básicas do país.

11The Post Disaster Needs Assessment (PDNA) publicado pelo Governo do Haiti, em março de 2010. Disponível em http://www.ht.undp.org/content/dam/haiti/docs/document-dereference/Evaluation \%20des\%20dommages, \%20des\%20pertes\%20et\%20des\%20besoins\%20généra. Acesso em: 15 de jan. de 2019. 
Segundo dados da PDNA (2010), a maior parte dos danos e prejuízos foi sofrida pelo setor privado estimada em US\$ 5,5 bilhões, enquanto o setor público foi afetado por um valor equivalente a US\$ 2,4 bilhões. O valor dos ativos físicos destruídos pelo desastre, incluindo unidades habitacionais, escolas, hospitais, prédios, hotéis, estradas, pontes, portos e aeroportos foi estimado em US\$ 4,3 bilhões. Houve variação nos fluxos econômicos como perda de produção, redução do volume de negócios, perda de empregos e salários, aumento nos custos de produção chega a US\$ 3,6 bilhões (PDNA, 2010).

\section{Mapa 2 -Vista global de destruição em Porto Príncipe no pós-terremoto}

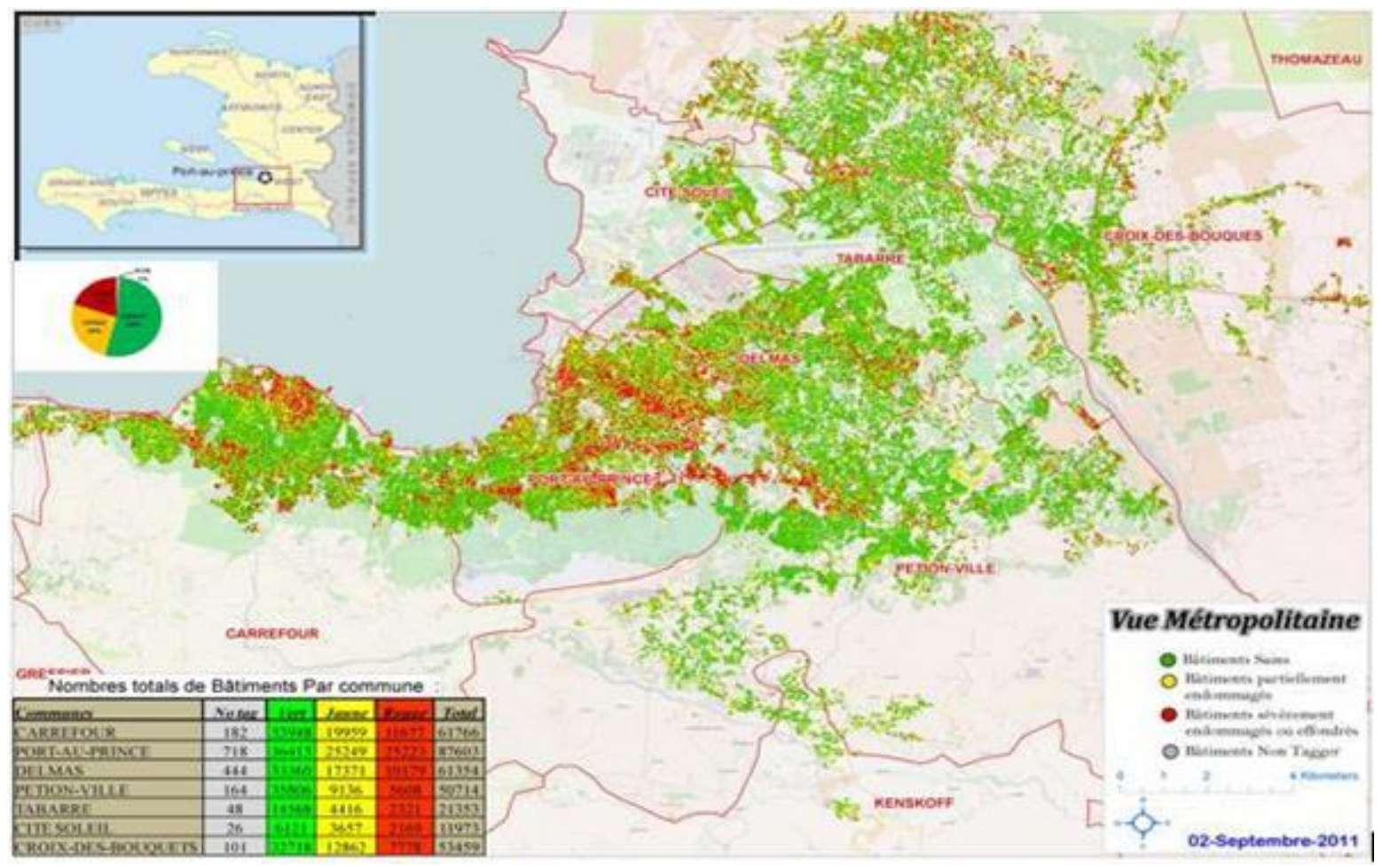

Fonte: MTPTC, 2001. Adaptação: Ismane Desrosiers, 2019.

O mapa 2 apresenta a vista global da destruição na cidade em que as construções em áreas verdes não foram afetadas, as amarelas foram parcialmente afetadas e as vermelhas foram totalmente destruídas (MTPTC, 2011). Dessa maneira, a habitação foi, sem dúvida, o setor mais afetado pelo terremoto, pois o dano total chegou a US\$2,3 bilhões. Este valor inclui o da destruição de unidades habitacionais de diferentes tipos e qualidades, o valor de casas e bens domésticos parcialmente ou totalmente danificados. As perdas de moradias são estimadas em US\$ 739 milhões. O setor habitacional, portanto, responde por aproximadamente $40 \%$ dos efeitos do terremoto o que agrava ainda mais o déficit habitacional na cidade. Os demais setores, em ordem decrescente de importância quanto aos efeitos sofridos são os de comércio em que prejuízos e perdas 
são estimados em US\$ 639 milhões e os edifícios da administração pública são avaliados em cerca US\$ 595 milhões (PDNA, 2010).

Além disso, os impactos do terremoto causaram uma mobilidade espacial após 2010, em que os sobreviventes da catástrofe deixaram as áreas afetadas para se deslocarem para locais considerados geograficamente mais seguros no interior do país. Esse fluxo migratório interno leva a uma redistribuição provisória da população no território nacional, como indicam as setas de destino dessa população no mapa 3 a seguir. Contudo, salientamos que o país também conhece, nos últimos 10 anos um fluxo de emigração de haitianos para América do Sul, sobretudo, no Brasil, porém, nossa preocupação nesta Dissertação não vai nessa direção.

\section{Mapa 3 - Mobilidade espacial da população pós-terremoto 2010}

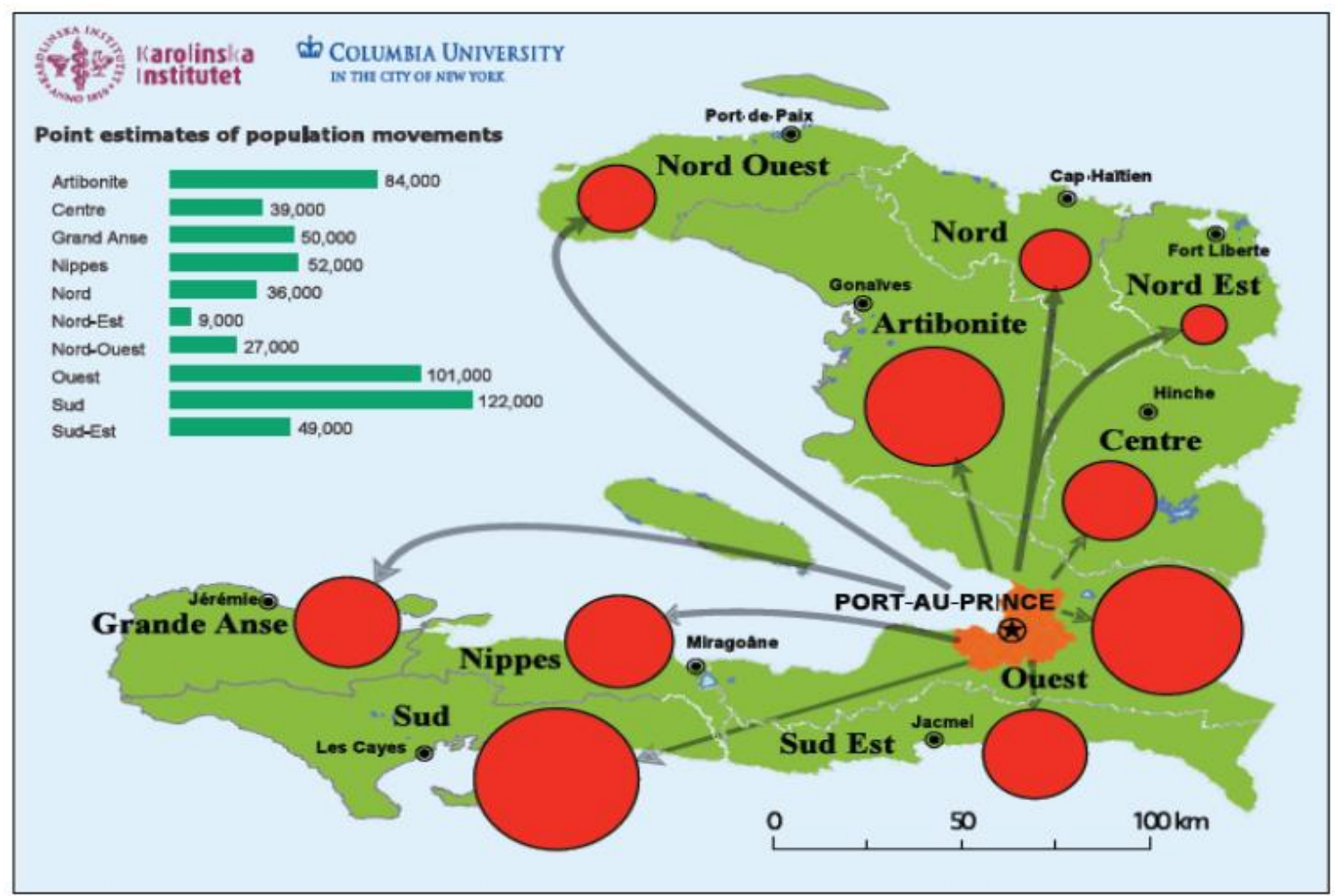

Fonte: Xin Lua, Linus Bengtsson and Petter Holmea, 2011.

O mapa 3 faz ver o movimento da população da região metropolitana de Porto Príncipe em direção ao interior do país, onde as desigualdades regionais são marcadas pela falta de acesso aos serviços básicos. Esse movimento de fuga para o interior evidencia um processo de descentralização populacional em Porto Príncipe, no entanto, de forma provisória na medida em que, de um lado, no interior do país as condições de vida são precárias. Por outro, a invasão de Organizações Não Governamentais (ONGs), especialmente após as primeiras semanas que seguem o evento concentraram suas ações de distribuição de ajuda humanitária em Porto Príncipe. De acordo com Edmond 
Mullet, ex-representante especial da Organização das Nações Unidas (ONU) no Haiti e chef da Missão das Nações Unidas para estabilização do Haiti (MINUSTHA), de 2010 a 2011, as agências somaram cerca de 10.000 ONGs entre 2010 a 2011 funcionando no território haitiano, principalmente, em Porto Príncipe.

Nesse sentido, sem recursos financeiros e materiais daqueles sobreviventes que foram para o interior do país, atraídos pelas ações dessas agências humanitárias na região metropolitana de Porto Príncipe em busca de meios de sobrevivência, tais como moradia, trabalho e alimentos. Portanto, as concentrações dessas ONGs na cidade contribuem para o retorno de pessoas em Porto Príncipe. Este intenso movimento de volta de pessoas em direção à metrópole produziu uma nova morfologia urbana da cidade no pós-terremoto de 2010. Isso tudo devido às novas áreas sendo urbanizadas pelos antigos e novos moradores que chegam à cidade, o que provoca o crescimento da demanda pelos serviços sociais básicos em Porto Príncipe de 2010 até a atualidade.

Gráfico 1 - O fluxo de retorno em Porto Príncipe 2010- 2011

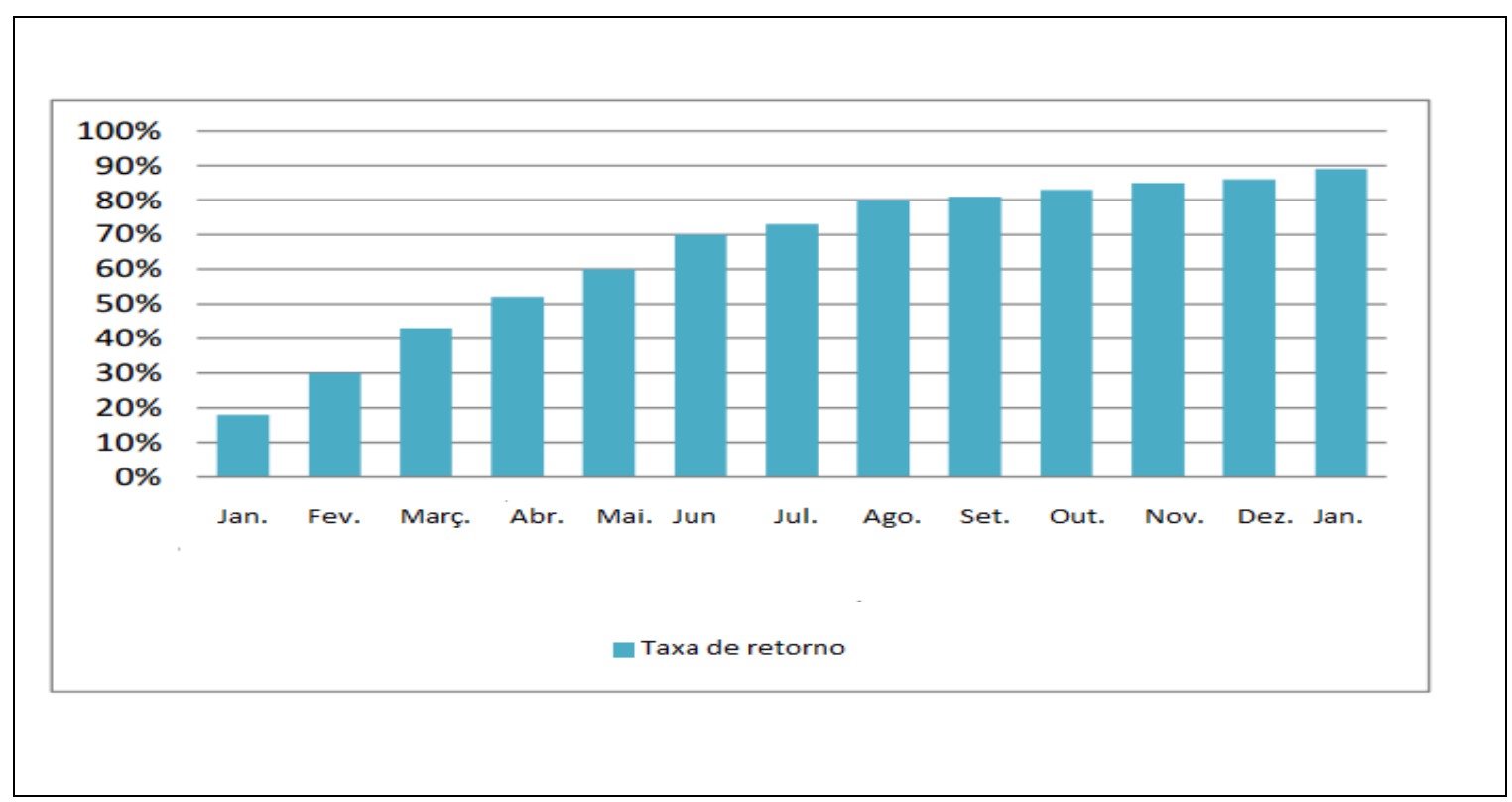

Fonte: Schawartz, 2011.

O gráfico 1 evidencia a taxa de retorno da população na região metropolitana de Porto Príncipe entre janeiro de 2010 a janeiro de 2011. Nesse movimento de retorno da população à metrópole emerge, a cerca $20 \mathrm{~km}$ da cidade de Porto Príncipe, um bidonville, uma favela de uma superfície de $27 \mathrm{~km}^{2}$ denominada Canaan. Hoje, segundo dados de IHSI (2018), essa vasta área quase desértica conta com uma população de mais de 200.000 habitantes vítimas do terremoto e migrantes de diferentes origens. Essa área conhece, na atualidade, um intenso processo de urbanização que analisamos no nosso artigo intitulado Haiti: um olhar crítico sobre o processo de urbanização de Canaan 
após 2010, publicado em $2017^{12}$. Nele propomos uma análise crítica das condições nas quais vivem a população ali após o terremoto.

A palavra Canaan ${ }^{13}$ (a terra prometida), também chamado de "Corail Cessless" ou "Jerusalem", é uma área localizada em Croix-des-Bouquets, um dos municípios do grande Porto Príncipe que mais sofreu distúrbios após o terremoto de janeiro de 2010; é o maior espaço na proximidade da capital ainda não urbanizado. Após o terremoto, por uma iniciativa do governo e das principais organizações internacionais e por meio do Decreto de 22 março de 2010, Canaan foi declarado de utilidade pública. Sua finalidade era realocar certas vítimas do desastre de janeiro de 2010 que viviam num campo do município de Petion-Ville, de condições geográficas perigosas, e acomodar cerca de 7 mil pessoas. Essa área hoje, de acordo com a definição operacional da ONU-HABITAT (2003), é uma verdadeira favela, ao privar seus habitantes dos seguintes serviços: acesso a água potável, saneamento básico, infraestruturas básicas, espaço de vida adequado, sustentabilidade da habitação e segurança de posse da terra (ONU-HABITAT, 2016 apud DESROSIERS, 2017).

No início da ocupação do espaço Canaan, invés do governo de então e as Organizações Não Governamentais (ONGs) proporem uma política pública de habitações duráveis, os organismos internacionais como a Organização Internacional para as Migrações (OIM), a World Vision (WV) e o Comitê Americano para os Refugiados (ARC) envolvidos na realocação das vítimas do desastre de 2010, ofereceram a cada família uma barraca. Depois, a maioria dessas barracas foi substituída por T-shelthers, (moradia temporária) que, segundo o economista Raymond Lafontan, entrevistado no Documentário: Assistência Mortal, de Raoul Peck (2012), custa entre US\$ 2 mil a US\$ 3 mil. Assim, o governo e as organizações internacionais optaram pela construção de moradia temporária. Esses abrigos são frágeis, suas estruturas de madeira clara diferem do quadro de concreto armado com enchimento de blocos de concreto que é usado para moradias duráveis. Além disso, eles não são transportáveis. De acordo com

12 Disponível em: http://agbcampinas.com.br/bcg/index.php/boletim-campineiro/article/view/351. 13A história do nome de Canaan é contada no livro bíblico do Êxodo $(12: 41,51)$ e relata que os filhos de Israel permaneceram no Egito durante séculos como escravos. Após a saída do Egito, passaram os primeiros quarenta e nove dias de liberdade no deserto, seguindo em direção ao Monte Sinai, local onde permaneceram aproximadamente por um ano e receberam os 10 mandamentos divinos, através de Moisés. $\mathrm{O}$ passo seguinte seria uma jornada de alguns dias em direção à Terra Prometida (naquele momento ainda conhecida como Terra de Canaã), que deveria ser conquistada e dividida entre as tribos formadoras do povo (MELAMED, 2011). No entanto, é Canaan que surgiu no Haiti, principalmente, na região metropolitana da cidade de Porto Príncipe, após o terremoto de 12 de janeiro de 2010 que nos interessa. 
Ian Davis, "a julgar pela experiência internacional, esses abrigos de baixa qualidade não serão demolidos, mas usados como casas por anos, o triste legado do desastre de 2010". Patrick Coulombel, por sua vez, diz que:

Eu me oponho fortemente a este tipo de intervenção, não é uma boa solução porque é possível construir casas sustentáveis, isto é apenas uma questão de vontade". Segundo ele, a importação de abrigos para montar no Haiti é comercialmente interessante para os vendedores, mas isso não ajuda o país a criar um mercado construtivo. Isso não promove o estabelecimento de setores econômicos de materiais de construção (COULOMBEL, 2011, p. 22 apud DESROSIERS, 2017, p. 391).

Após dez (10) anos que se seguiram ao terremoto, os governos haitianos e os parceiros internacionais não apoiaram o processo de urbanização de Canaan, que rapidamente se tornou o maior e mais ativo local de construção do país, ao ponto que se tornou o maior assentamento urbano no Haiti após 2010. Tudo isso, construído inteiramente pelos próprios moradores sem técnicas ou apoio financeiro de parceiros municipais, estaduais ou internacionais. Além disso, Canaan não é muito coberto por meios de imprensa internacionais ou nacionais, já que a maioria dos esforços de comunicação foi feita para destacar as "conquistas" das ONGs internacionais por meio de distribuição de alimentos, barracas e da água (DESROSIERS, 2017).

Outro discurso ideológico dessas agências é o de que "o Haiti é o país mais pobre da América", pois a maioria das ONGs acredita que é importante mencionar isso em seus websites como uma declaração introdutória ou justificativa para suas atividades no país. Entretanto, o crescimento urbano de Canaan como a imagem mais marcante e visível na região metropolitana de Porto Príncipe no pós-desastre foi combinado com planos para esvaziá-lo, deixando a complexa dinâmica socioespacial dessa área fora do centro das atenções. Segundo Moran (2015), Canaan é uma expansão urbana de Porto Príncipe descontrolada, um “desenvolvimento urbano anárquico”. Para Décimé (2012), é uma "urbanização selvagem". Watch, (2013), por sua vez, diz que a ocupação do espaço de Canaan é "degradante", concordamos com esse autor, pois a área não foi idealmente planejada o que apresenta um risco para os habitantes. Para esses autores, Canaan já é percebido como gigantesca e preocupante favela bidonville na região metropolitana de Porto Príncipe. Esta nova área está se urbanizando, principalmente, por habitantes desfavorecidos na estrutura urbana de Porto Príncipe antes do terremoto de 2010. Esses novos moradores entraram numa dinâmica de venda e de compra de terra "ilegalmente" além do perímetro que foi declarado de utilidade pública por meio 
do Decreto de 22 de março de 2010. Nesse sentido, pode-se dizer que há um aumento das desigualdades socioespaciais na metrópole na medida em que os habitantes de Canaan vivem em situação de privação. A urbanização da área ocorre sem seguir um Plano Diretor que é o instrumento do desenvolvimento urbano da cidade no que tange aos seus aspectos físico-territoriais como mostra a figura 1

Figura 1 - Vista aérea da ocupação do espaço Canaan em 2015

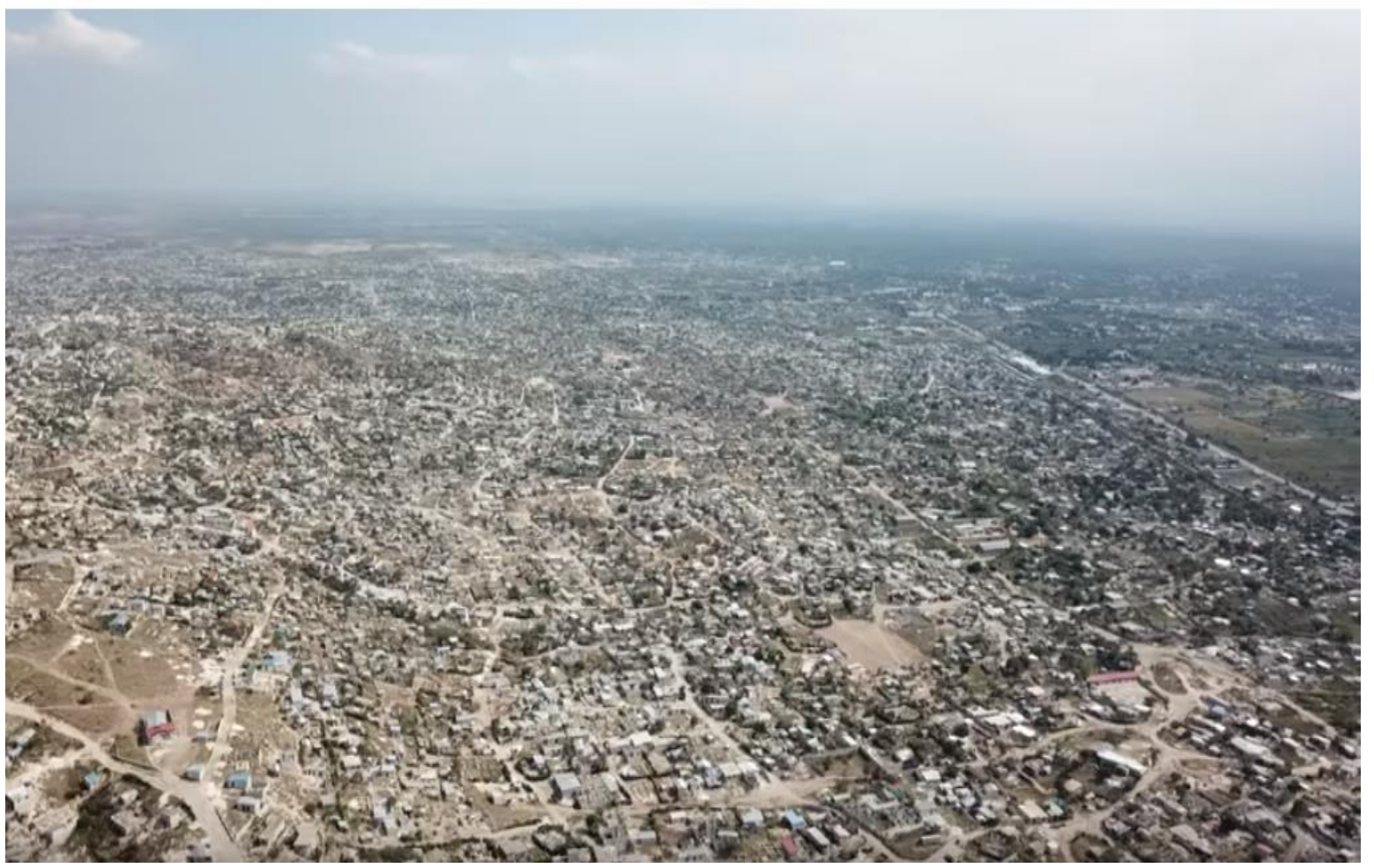

Fonte: Disponível em: https://www.youtube.com/watch?v=YopoEuwLf2Y. Acesso em: 25 de abr. 2019

A figura 1 mostra uma urbanização caótica do espaço de Canaan na ausência de um Plano Diretor, o processo está impulsionado por iniciativas individuais ditadas por estratégias de sobrevivência. Tudo isso pode ser evidenciado pelos arranjos espaciais das moradias, em que quase não existem vias principais e secundárias tracejadas. A imagem faz ver que as ruas dessa vasta área não são pavimentadas. Além disso, os habitantes de Canaan, na atualidade sofrem da falta de acesso aos serviços básicos em termos de distribuição de equipamentos urbanos, tais como: moradia descente, emprego, água, saneamento básico, eletricidade, centro de saúde, centros educacionais, centros culturais, espaços de lazer, área verde, transporte e mobilidade urbana de qualidade. Portanto, além da desigualdade de renda, esses são os principais elementos que caracterizem as desigualdades socioespaciais comparando-os às outras áreas urbanas abastadas por essas infraestruturas e equipamentos em Porto Príncipe. Isso, de alguma forma, é a realidade das metrópoles de países inseridos na periferia do capitalismo. 
Dentro dessa dinâmica espacial assistimos, portanto, no pós-terremoto a uma nova morfologia urbana de Porto Príncipe marcada por um intenso processo de metropolização da cidade. Isso pode ser notado através do crescimento da área da região metropolitana de Porto Príncipe, principalmente, de 2010 a 2017 como indica o mapa 4.

\section{Mapa 4 - Processo de metropolização de Porto Príncipe após 2010}

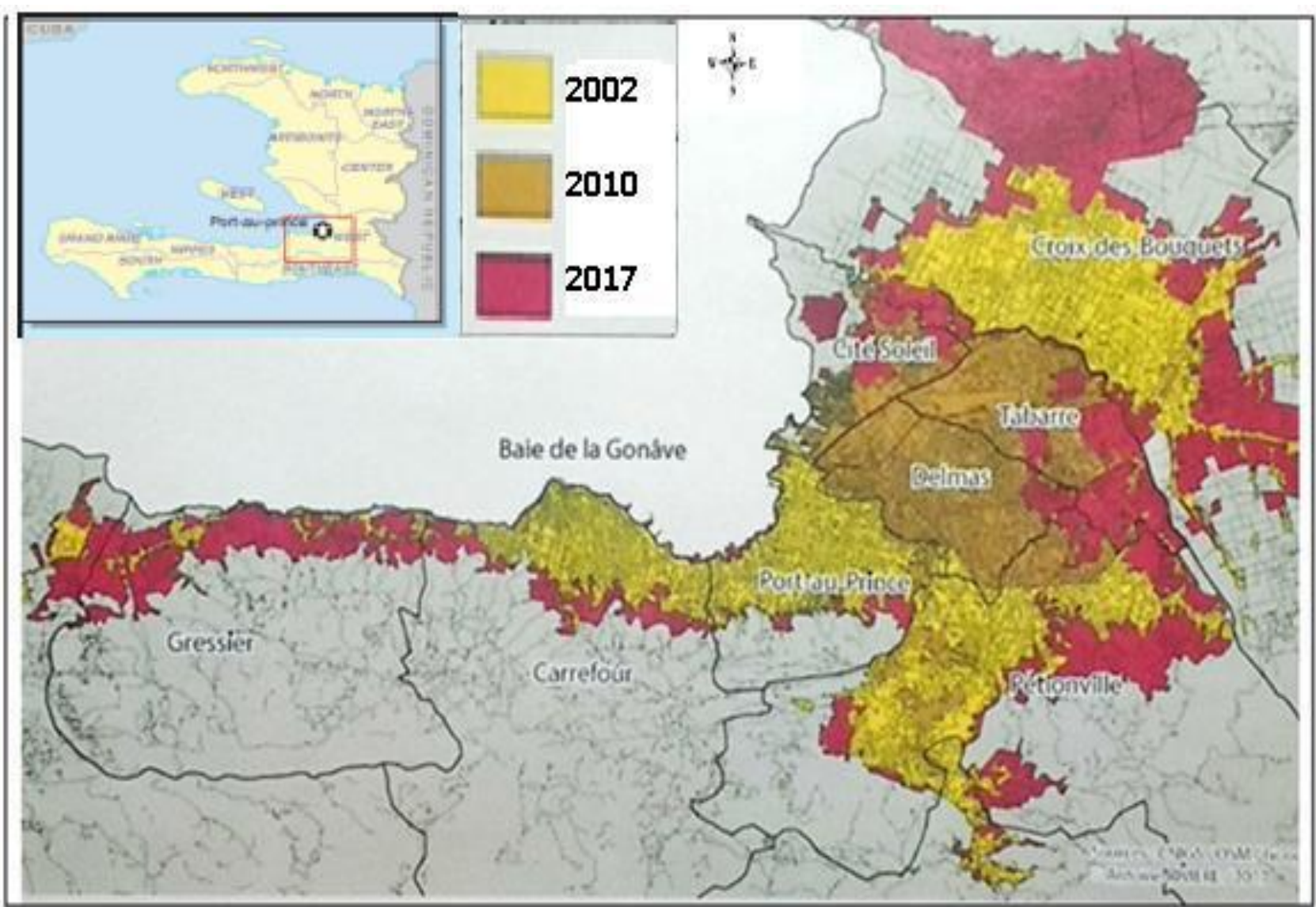

Fonte: CNIGS, 2017. Adaptação: Ismane Desrosiers, 2019.

O mapa 4 evidencia o processo de metropolização ou favelização/ bidonvilisation de Porto Príncipe marcado, por um intenso crescimento da área (vermelha) metropolitana de 2010 a 2017. Contudo, esse processo continua até a atualidade, principalmente, ao norte de Porto Príncipe onde se localiza Canaan. Essa parte da região metropolitana tornou-se o símbolo de uma reconstrução mal definida, na medida em que é a população que decide construir sua própria cidade, em busca de alternativa de sobrevivência. Por conseguinte, a urbanização da área não sendo o resultado de uma ação concertada no nível de tomada de decisão pelo governo municipal nem pelo governo central. Ou seja, veremos mais adiante que essa área está fora dos planos e projetos de reconstrução. 


\subsection{Os planos, financiamentos da reconstrução do Haiti e de projetos de requalificação urbana do centro de Porto Príncipe pós-terremoto de 2010.}

Após o desastre ocorreu, em Nova York, em 31 de março de 2010, uma conferência sobre a reconstrução do Haiti intitulada "Towards a New Future of Haiti" ${ }^{14 \text { ", }}$ (Rumo a um novo futuro para o Haiti). Nessa conferencia foi prometido um valor de US\$ 12 bilhões de ajuda humanitária e para reconstrução do Haiti (CHARLMERS, 2012) ${ }^{15}$. Nesse sentido, os parceiros internacionais se comprometeram a apoiar a reconstrução do Haiti e aceitaram o princípio do apoio de longo prazo. Foi nesse contexto que o Plano de Ação para a Recuperação e Desenvolvimento do Haiti $(\mathrm{PARDH})^{16}$ foi elaborado para apresentar as principais diretrizes nacionais para reconstruir o Haiti. Tudo isso, com uma nova base, pois as áreas devastadas pelo terremoto expuseram um estado insuportável de vulnerabilidade que requeria uma visão que fosse além da resposta às perdas de vidadas e danos enregistados. Esse referido plano serviu, no período entre 2010 a 2012 como um guia para as autoridades nacionais e seus parceiros internacionais iniciarem ou implementarem um conjunto de medidas de emergência e desencadearem os projetos para colocar o Haiti no caminho de mudança desejado por todos e torná-lo um país emergente no horizonte de 2030 (HAITI, 2010).

O objetivo do Plano de Ação para Recuperação e Desenvolvimento do Haiti consiste em lidar com a situação de urgência pós-catástrofe e do futuro imediato, reiniciar atividades econômicas, governamentais, sociais, reduzir a vulnerabilidade do país diante de desastres naturais e lançar o Haiti no caminho de desenvolvimento. Este plano é dividido em duas etapas. De um lado, a do imediato que cobre um período de dezoito meses, que inclui o fim do período de emergência e a preparação dos projetos, iniciando a reconstrução do país. Por outro, o período que abre uma perspectiva temporal de dez anos, permitindo a realização de projetos e programação das Estratégias Nacionais de Crescimento e Redução da Pobreza (HAITI, 2010).

14 Mais informações disponíveis em: https://www.youtube.com/watch?v=LPvkoLZIjms Acesso em: 20 de abr. de 2019.

15 CAMILLE Charlmers :Le bilan économique de la « reconstruction » en Haïti,

2012: Disponívem em http://www.cahiersdusocialisme.org/2012/08/02/haiti-lebilan-economique-de-la-

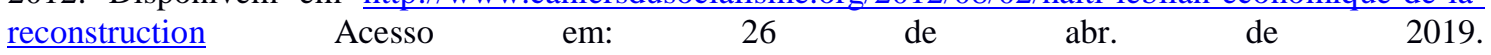

16 Disponível em: https://issat.dcaf.ch/Learn/Resource-Library2/Policy-and-Research-Papers/Plan-daction-pour-le-relevement-et-le-developpement-d-Haiti.-Les-grands-chantiers-pour-l-avenir Acesso em: 25 de abr. de 2019. 


\section{Gráfico 2 - Os principais países e organismos doadores pela reconstrução do Haiti}

entre 2010 a 2011

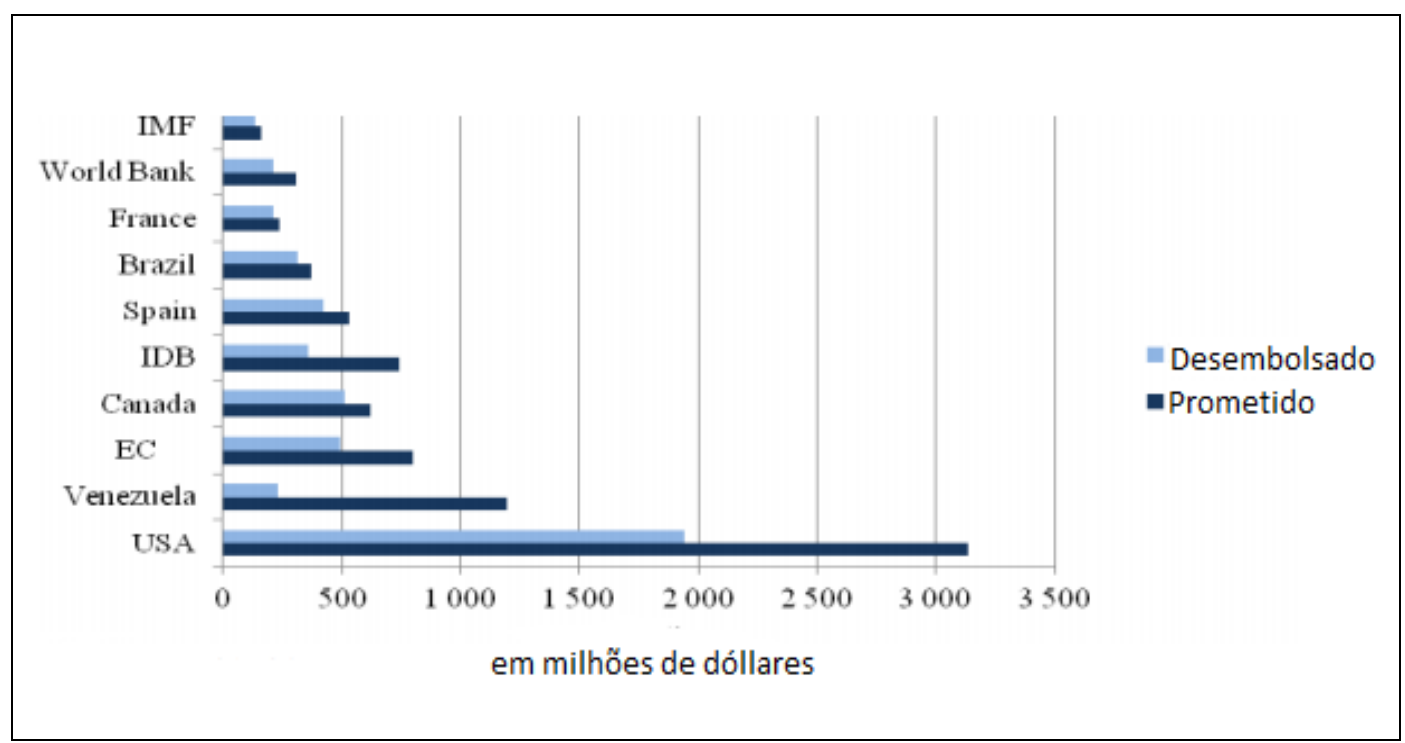

Fonte: Ramachanran et al (2012. p. 6). Adaptação: Ismane Desrosiers, 2019.

O gráfico 2 indica a contribuição de países e instituições internacionais para reconstrução do Haiti pós-terremoto de 2010. No âmbito da reconstrução do país, a formulação de programas, projetos seu financiamento e as suas execuções não ocorrem a partir de uma abordagem coordenada e coerente junto com as autoridades haitianas. Isso pode ser demostrado pelo posicionamento de países (Estados Unidos, França, Canadá) que acusavam a capacidade limitada do Estado haitiano e das instituições nacionais para gerar os fundos. Para Seitenfus (2010, p. 5), essa visão trata-se de um discurso ideológico que abriu as portas para que as ONGs e os operadores privados desempenhassem papel cada vez mais importante no Haiti, tornando-se principais canais para a ajuda externa para o Haiti. Nessa direção, Seitenfus afirma que:

A ajuda de emergência é eficaz. Mas quando se torna estrutural, quando se substitui o Estado em todas as suas missões, esta abordagem levaria a uma não responsabilidade coletiva. Se houver prova do fracasso da ajuda internacional, é o Haiti. O país tornou-se a Meca [...]. A comunidade internacional tem a sensação de ter que refazer todos os dias o que ela terminou no dia anterior. Fadiga do Haiti começa a despontar (SEITENFUS, 2010. p. 2).

Entretanto, por certos autores como o próprio Ricardo Seitenfus (2010), Charlmers (2012), Ramachanran et al (2012), o melhor canal era dar apoio direto ao Estado haitiano e aos planos de reconstrução liderados pelos haitianos. Assim, essa ajuda poderia colocar o Haiti no caminho da reconstrução e do desenvolvimento, da 
justiça social e de um futuro melhor. Portanto, concordamos com a visão desses autores, já que o Estado tem a tarefa de reforçar a coesão social, a implementação no território de políticas sociais e coordenar melhor as suas intervenções, junto com as competências de seus diferentes componentes, notadamente, as autoridades locais. Todavia, a maioria desses papéis do Estado haitiano foram substituídos pelas ONGs, que construíram um poderoso "Estado paralelo" (Ramachanran et al 2012) ${ }^{17}$. Nesse movimento, entre 2010 a 2011 o Estado haitiano recebe somente 1\% dos fundos doados por países e instituições internacionais envolvidos na reconstrução do Haiti como indica no gráfico 3.

\section{Gráfico 3 - Beneficiários dos fundos para reconstrução do Haiti entre 2010-2011}

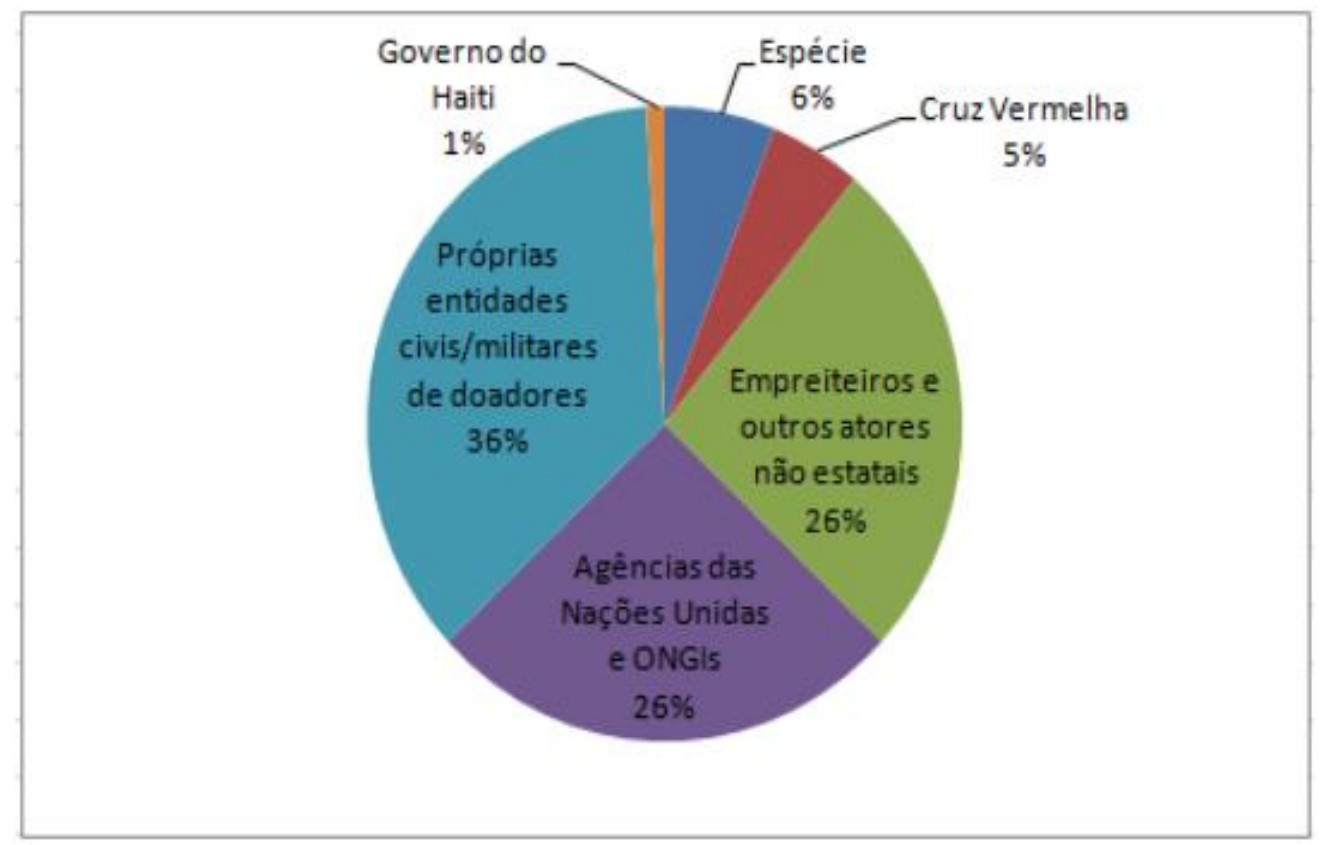

Fonte: Ramachanran et al (2012, p. 9). Adaptação: Ismane Desrosiers, 2019.

O gráfico 3 apresenta os beneficiários dos fundos para reconstrução do Haiti no período que compreende entre 2010 e 2011, quando a maior parte dos fundos foi para entidades militares/civis, agências das Nações Unidas e de Organizações Não Governamentais. Essas ONGs e a agências internacionais levantaram e controlaram milhões de dólares com a promessa de prestar assistência às vítimas do terremoto no Haiti e, em seguida, reconstruir o país. Mas, esses milhões foram supostamente desviados pelas ONGs se tomamos como exemplo o surgimento e a expansão de 
Canaan área de atuação de ONGs na região metropolitana de Porto Príncipe, onde como já vimos anteriormente, as condições de vida dos moradores são precárias.

O Plano de Ação para a Recuperação e Desenvolvimento do Haiti (PARDH) foi modificado, em 2012, pelo governo haitiano em Plano Estratégico de Desenvolvimento do Haiti (PSDH): "país emergentes em 2030"." Objetiva-se uma visão de desenvolvimento da nação haitiana ao longo prazo. A meta é que o Haiti se torne um país emergente até 2030. Para isso, o plano incentiva os investimentos no Haiti, especialmente os de estrangeiros para criação de emprego no âmbito de aumentar a renda média da população. Por exemplo, aumentar a renda média per capita de US\$ 850 para US\$ 2.310. Tudo isso, por uma melhoria real das condições de vida no Haiti, dado que os países considerados "emergentes" têm uma renda média que varia de US\$ 995 a US\$ 3945 (HAITI, 2012). O plano descreve brevemente quatro principais eixos de ações a serem implementadas na reconstrução do país. Dessa maneira, foram listadas medidas urgentes para lidar com os desafios de curto prazo ilustrando o desencadeamento de projetos para reconstruir o país e planejar novas modalidades para cooperação entre parceiros internacionais. Esses quatro grandes eixos a serem considerados sãos os seguintes: a "refundação" territorial, econômica, social e institucional (HAITI, PSDH, 2012). Qual é a viabilidade deste plano de reconstrução?

A "refundação" territorial, ou melhor, o plano prevê o planejamento territorial e urbano, o desenvolvimento local, a proteção ambiental, e a requalificação urbana. Salientamos isso, pois, acreditamos que o território nacional não pode fundar de novo após 1804. Dito isso, apoiando em Claude Rafestin (1993), que segundo este autor o território é o espaço físico, onde se localiza uma nação em que se delimita uma ordem jurídica e política marcada pela projeção do trabalho humano com suas linhas, limites e fronteiras. Contudo, a implementação desse plano permitirá a diminuição das desigualdades regionais no Haiti. Uma vez que são contidos no plano o estabelecimento de uma rede de transporte nacional, a eletrificação do país, a expansão das comunicações no território, bem como o aumento das capacidades de abastecimento de água potável e saneamento básico, incluindo a gestão de resíduos sólidos. Isso são condições infraestruturais necessárias ao crescimento econômico, à criação de emprego,

18 Disponível em:

https://www.undp.org/content/dam/haiti/docs/Gouvernance $\% 20 \mathrm{~d} \% \mathrm{C} 3 \%$ A9mocratique $\% 20$ et $\% 20$ etat $\% 20$ de\%20droit/UNDP_HT PLAN\%20STRAT\%C3\%89GIQUE\%20de\%20developpement\%20Haiti_tome2. pdf. Acesso em 22 de abr. de 2019. 
ao acesso aos serviços sociais, com a intenção de reforçar as economias regionais, estimular o desenvolvimento local, no contexto da urbanização (HAITI, 2012).

Do ponto de vista econômico, o plano prevê a implementação de um quadro macroeconômico, que conduz ao desenvolvimento do país. Tudo isso com investimento privado interno e externo, modernização da agricultura, pecuária e pescas, setores competitivos da economia haitiana e, em particular, da indústria transformadora e do turismo. A criação de uma verdadeira indústria da construção, o desenvolvimento do setor dos serviços, a exploração sustentável dos recursos minerais. A implementação de projetos orientados para a criação de emprego, bem como para melhorar a produtividade e a empregabilidade. Esses programas estimularão a criação de riqueza e empregos, aumentarão a renda pessoal, fortalecerão o setor privado, promoverão a estabilização da população, aumentarão a segurança alimentar e reduzirão as pressões sobre o meio ambiente e os recursos naturais (HAITI, 2012).

Do ponto de vista social, o plano prevê a criação de redes modernas de saúde e educação em todo o país, incluindo o ensino superior, a formação profissional, técnica, a proteção da propriedade cultural e o apoio à criatividade cultural. Almeja também um melhor acesso à habitação, o desenvolvimento da ação cívica, da prestação de desporto, a recreação de um sistema de segurança social para todos os trabalhadores. A organização da solidariedade social e um programa de promoção da igualdade de gênero. Estes programas acabarão por cobrir todo o território nos serviços básicos, participarão no estabelecimento de polos regionais e locais de desenvolvimento, melhorarão as condições habitacionais, promoverão a inclusão social, constituirão eixos de criação de riqueza e empregos com objetivo do crescimento da classe média (HAITI, 2012E, por fim, o plano prevê a revisão do quadro jurídico e institucional. Tudo isso para reforçar e dinamizar os poderes legislativo, judiciário e as demais instituições independentes. Propõe a modernização da administração pública e, em especial, a administração da justiça e da segurança pública, o aumento do número de funcionários na administração pública, o fortalecimento das Coletividades Territoriais ${ }^{19}$ e o

19 As coletividades territoriais são instituições territoriais político-administrativas descentralizadas no Estado Unitário Descentralizado do Haiti. São unidades territoriais autônomas descentralizadas (Departamento, Município ou Comuna, Secção Comunal) de caráter participativo, que contribuem para a implementação de políticas de ordenamento territorial e de gestão de negócios públicos. Elas constituem o marco de mobilização e participação de sua população para promover o progresso social, econômico e cultural. As Comunidades Territoriais têm competências que lhes são atribuídas pela Constituição e pela lei e cujo exercício pode ser contestado em justiça, particularmente em matéria de responsabilidade civil (HAITI, 1987). 
fortalecimento da sociedade civil. A realização desse plano permite a construção de um Estado forte, desconcentrado e descentralizado o estabelecimento de uma cultura de transparência e a prestação de contas que torne a corrupção "impraticável” no território, adapte o arcabouço legal e regulatório às necessidades, assegure uma melhor gestão da terra e garantir a proteção da propriedade (HAITI, 2012).

Com efeito, cabe salientar que os financiamentos do plano de reconstrução do Haiti, em particular, o da cidade de Porto Príncipe no pós-terremoto de 2010 têm cinco origens seguintes: recursos nacionais, o fundo para reconstrução do Haiti, apoio orçamental, financiamento bilateral e multilateral (HAITI, 2015) ${ }^{20}$. O financiamento para o desenvolvimento, a operação de grandes projetos de infraestruturas e equipamentos dependem do investimento público nacional em parceria com o privado e de apoio externo. Por outro lado, há um esforço para aumentar a capacidade de financiamento das autoridades locais para o estabelecimento e, manutenção de serviços, infraestruturas e equipamentos sob a sua jurisdição. Já que capacidade das autoridades locais precisa ser fortemente apoiada pelo orçamento nacional (HAITI, 2012).

\section{Mapa 5 - Polos de desenvolvimento regional}

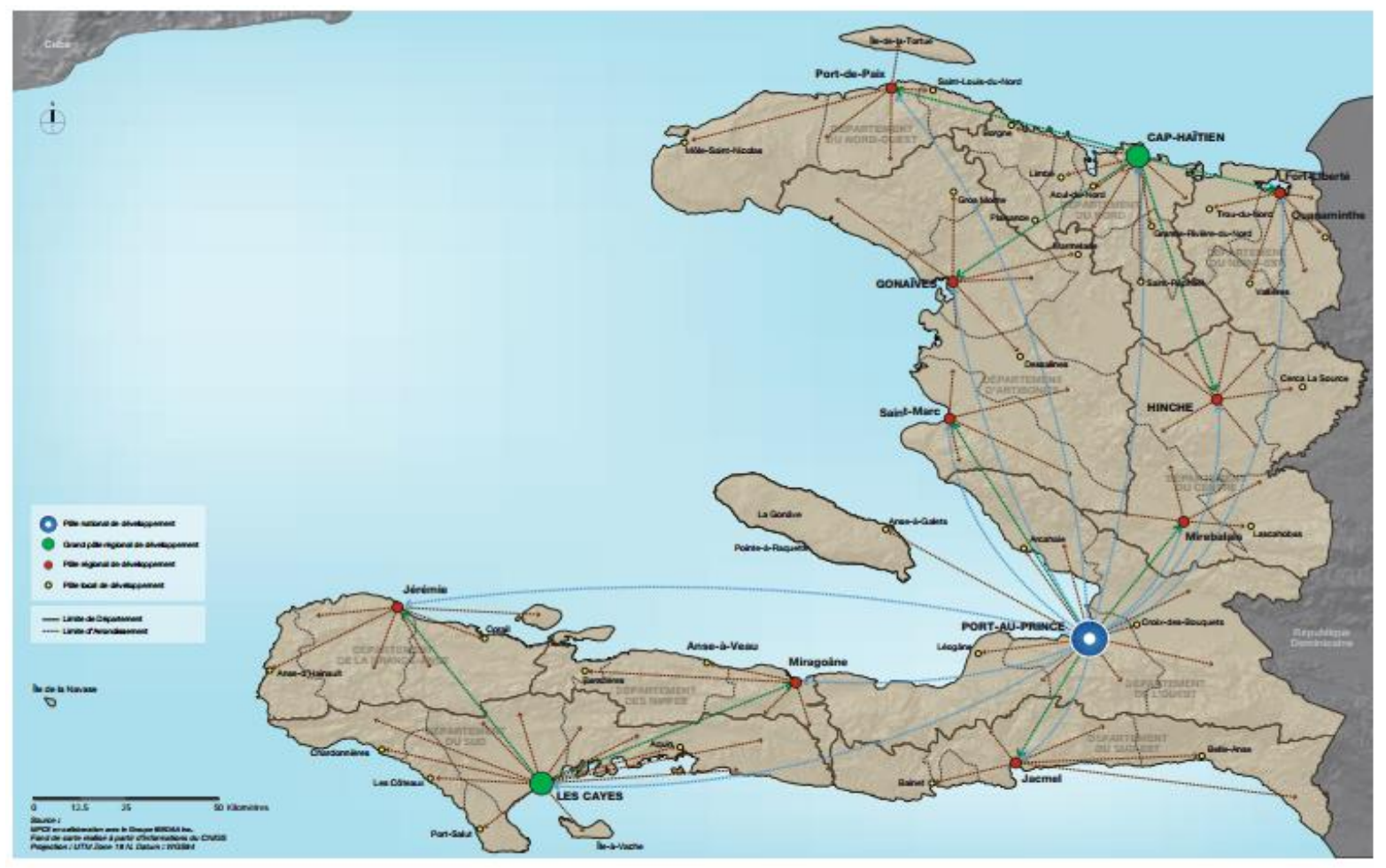

Fonte: PSDH, 2012

20 Mais informações disponíveis em: https://www.haitireconstructionfund.org/system/files?file=documents/Universalia_FRH_Rapport\%20FIN AL_Avril2015.pdf Acesso em: 30 de abr. de 2019. 
O mapa 5 apresenta o território haitiano, cuja superfície é de $27.750 \mathrm{~km}^{2}$. Nele observamos, no âmbito do PSDH, os polos de desenvolvimento regionais com destaque para as cidades de três grandes regiões do país: a região Oeste (da capital), Norte e Sul para um desenvolvimento integrado do território nacional. Além disso, o plano propõe serviços descentralizados da administração pública nas Coletividades Territoriais para reforçar a convergência e a coerência das ações, no intuito de adaptá-las às necessidades e aos interesses atuais do desenvolvimento como proteção de bacias hidrográficas e o controle da urbanização nas cidades do interior.

Com efeito, além do PSDH, vários trabalhos (estudos, diagnósticos, artigos, relatórios de estado, planos) foram produzidos sobre o Haiti no contexto pós-desastre. De fato, identificamos inúmeros estudos e relatórios produzidos desde 2010, no Haiti ou em outros países abordando direta ou indiretamente a questão urbana de Porto Príncipe, bem como os planos de desenvolvimento ou documentos recentes de planejamento urbano. Desse modo, inúmeras soluções, estratégias e hipóteses já foram propostas nesses documentos e trabalhos científicos no contexto pós-desastre que vive a metrópole haitiana. Mas, acompanhamos com preocupação o processo de reconstrução do país, em particular, a cidade de Porto Príncipe no pós-terremoto, pois cremos que os meios limitados de financiamentos constituem o principal obstáculo à realização dos planos e projetos. Além disso, as soluções e estratégias propostas nos planos respondem muito mal às necessidades e expectativas dos habitantes da metrópole Porto Príncipe e no Haiti como o todo. Tudo isso, com a previsão da diminuição das desigualdades e com a instauração do bem-estar coletivo sonhado pela maioria dos haitianos mesmo antes do desastre de 2010.

Contudo, no nível institucional, a contribuição recente mais importante no âmbito da reconstrução da cidade é a criação da Unidade de Construção de Habitações e de Edifícios Públicos (UCLBP), responsável pela política do desenvolvimento urbano da cidade sendo um ator cada vez mais influente para a transformação urbana da metrópole. Outra medida notável após o terremoto de 2010 é a criação da Comunidade de Municípios da região de palmes, uma tentativa interessante de responder às questões metropolitanas de maneira correta entre os municípios (MICT, 2010). No nível normativo, iniciativas importantes incluem o estabelecimento do Código Nacional de Construção no Haiti (MTPTC, 2012). Um esforço, também, foi feito para divulgar as melhores práticas de planejamento e construção. Nessa direção, numerosos documentos de apoio foram produzidos, incluindo o Guia para o profissional do planejamento, leis e 
regulamentos (MTPTC, 2013), o Guia para o profissional de reabilitação de bairros (MTPTC, 2013), a estrutura metodológica padrão do plano desenvolvimento comunitário (MTPTC).

No que tange ao centro da cidade de Porto Príncipe em 2010, o governo de René Préval (2006-2011) criou o Comitê de Facilitação da Reconstrução do Centro (CFRC) por meio de um Decreto ${ }^{21}$ que declarou o centro da cidade de utilidade pública. Expropriando, assim, vários terrenos privados no centro. Esse Decreto foi então sobreposto a um segundo em 2012, sob o governo de Michel Joseph Martelly (20112016). Esse último foi seguido por vários planos de desenvolvimento, tais como o projeto de requalificação urbana da Fundação Prince Charles ${ }^{22}$, do Reino Unido, em parceria com a empresa de planejamento urbano dos EUA Duany-Plater-Zyberk $(\mathrm{DPZ})^{23}$; um segundo encomendado pela Câmara Municipal em colaboração com Centro Haitiano de Pesquisa em Planejamento e Desenvolvimento (CHRAD) e finalmente, outro comissionado pelo Ministério do Planejamento e Cooperação Externa da empresa canadense IBI/DAA para planejar a reconstrução da capital (MPCE, 2013).

Segundo Etienne $(2013)^{24}$, após o terremoto, a metrópole tem sido objeto de uma série de ferramentas de planejamento, incluindo mais de 18 projetos de planejamento urbano entre eles há um plano diretor do Centro Histórico, Plano Urbano Local, a Zona de Desenvolvimento Concertado (ZAC), o Esquema de Coerência Territorial (SCOT), os documentos da Região Metropolitana de Porto Príncipe. A qualidade de muitos desses planos pode certamente ser questionada e seu impacto é muitas vezes insignificante, mas torna-se cada vez mais difícil argumentar que há falta de planos para a cidade. Entretanto, quais são os limites e as vantagens desses planos de requalificação urbana de Porto Príncipe? Em que sentido esses planos podem contribuir na diminuição das desigualdades socioespaciais na metrópole?

Nesse movimento de reconstrução do Haiti no pós-terremoto de 2010, em particular, a cidade de Porto Príncipe destacamos, principalmente, o projeto de

21 Disponível em: https://www.haitilibre.com/article-1156-haiti-reconstruction-publication-de-l-arrete-dexpropriation-du-centre-ville-de-pap.html. Acesso em: 10 de maio de 2019.

22. Mais informações disponíveis em:

https://www.theguardian.com/world/2010/oct/10/prince-charles-haiti-architecture Acesso em: 10 de maio de 2019.

23 Disponível em: https://www.dpz.com/Projects/1013 Acesso em: 30 de abr. de 2019.

24 Eienne, J. O. Les stratégies étatiques et municipales de reconstruction post-catastrophe du centre-ville historique de Port-au-Prince: Vers une re-appropriation territoriale divergente? RUR@LITES, 3, 1-25. (2013). 
requalificação urbana promovido pela Fundação Príncipe Charles, do Reino Unido e seus associados, junto com a empresa de arquitetura Duany Plater-Zyberk, (DPZ) com sede em Miami, EUA, em colaboração com o governo do Haiti, em 2011. E o projeto de requalificação urbana articulado pelo governo haitiano intitulado: Cité Administrative, Cidade Administrativa por meio da Unidade de Construção de Habitação e Edifícios Públicos (UCLBP) em 2012. Nessa direção, o projeto DPZ idealmente foi projetado, principalmente em três eixos: infraestruturas viárias de transportes, edifícios residenciais, comerciais e edifícios da administração pública conforme indica a figura 2.

Figura 2 - Projeto de requalificação urbana do centro de Porto Príncipe da Fundação Prince Charles, 2011

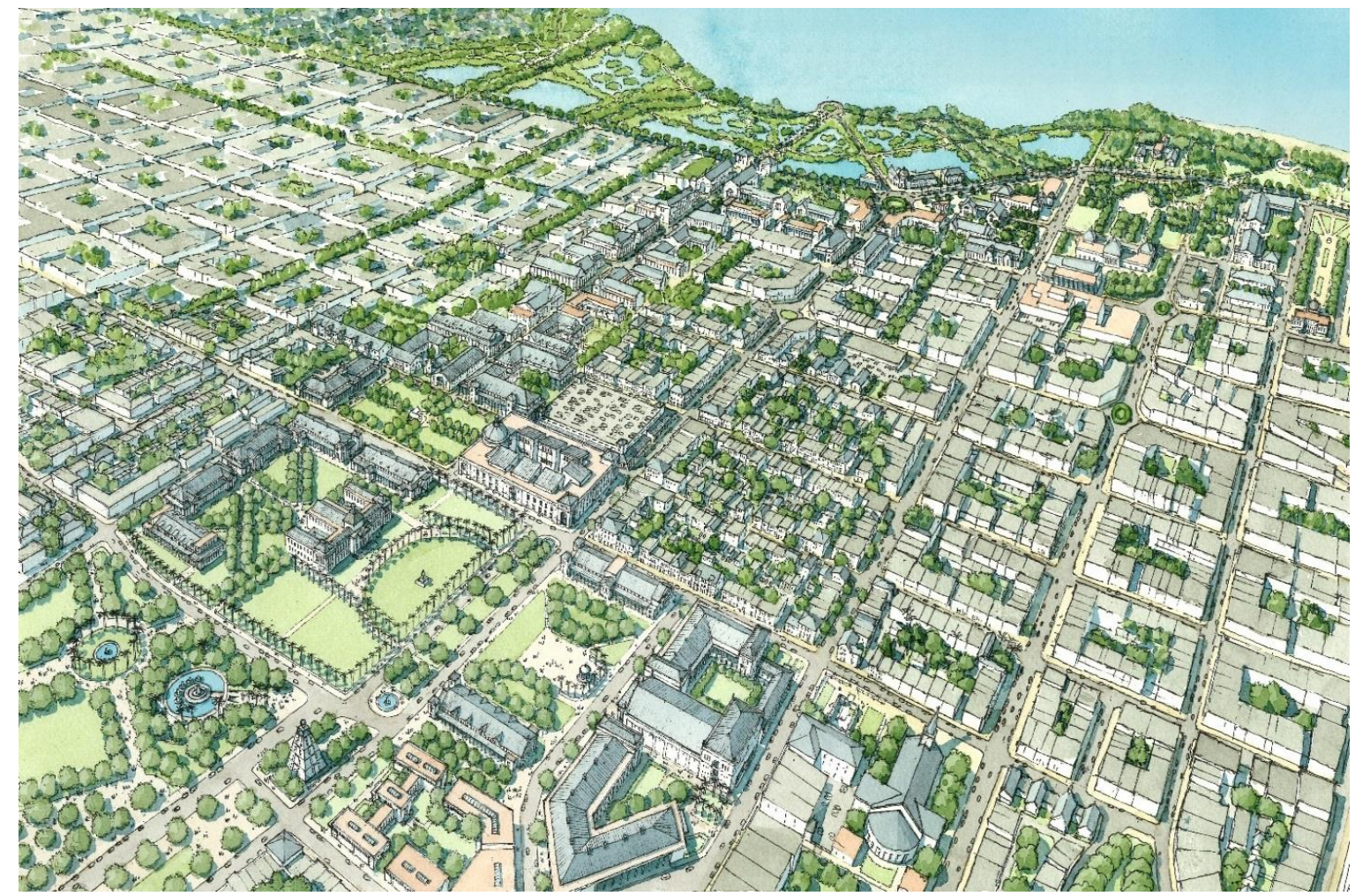

Fonte: DPZ, 2011

A figura 2 apresenta o projeto de requalificação urbana do centro de Porto Príncipe no pós-terremoto. Nele observamos que Plano Diretor incorpora todas as funções essenciais de um plano de desenvolvimento da cidade respeitando as condições existentes das ruas e da geometria do centro histórico. Tudo isso, com a distribuição dos edifícios públicos, privados, áreas de atividade comercial; áreas residenciais, espaços verdes, corredores de transporte urbano. Contudo, quais são os perfis socioeconômicos dos moradores que morariam no centro dessa cidade? Já que os elementos básicos da estrutura urbana no Plano Diretor se constituem em centro Urbano, do Corredor Urbano e da Vila Urbana marcados por corredores de transporte, espaços públicos, privados e 
edifícios. Além disso, existem áreas verdes que são locais de frequentação, de lazer e o porto turístico no litoral.

O projeto de requalificação urbana de 2011, da Fundação Príncipe Charles, do Reino Unido, inclui os usos das vias que existiam no espaço urbano da cidade e propõe planos de reordenamento urbano, modificando-os e desenvolvendo-os em resposta ao contexto socioeconômico pós-terremoto. Desse modo, o projeto inclui áreas de lojas comerciais para turistas de cruzeiros que chegam ao porto turístico na parte litoral da cidade. Este plano específico do centro implica uma excursão extensa e coerente de leste a oeste, que termina na Cathédrale Notre-Dame de Port-au-Prince e no Palácio Presidencial (DPZ, 2011). Todavia, este projeto não vai adiante, pois nove (9) anos após o terremoto sua implementação não está sendo constatada.

Como veremos no segundo capítulo da dissertação em 1949, na ocasião da Exposição Bicentenária da Fundação Porto Príncipe, a cidade conheceu um processo de "embelezamento" por meio de um projeto de requalificação urbana marcada pela construção da avenida Harry Truman à beira-mar, com dois quilômetros de extensão, jardins, espaços públicos, de serviço e de lazer. No contexto do pós-terremoto de 2010 , como já foi mencionado há vários planos e projetos de reconstrução da cidade de Porto Príncipe. Por exemplo, o ambicioso projeto de requalificação urbano da Fundação Príncipe Charles, do Reino Unido recapitulando, não se concretizou de fato.

Contudo, assistimos desde 2012, a implementação do projeto requalificação urbana do centro de Porto Príncipe intitulado Cité Administrative (Cidade Administrativa), elaborado pelo governo haitiano por meio da Unidade de Construção de Habitações e Edifícios Públicos (UCLBP) ${ }^{25}$ após o desastre de 2010. Sendo a maior intervenção urbana em andamento por nossos governantes. A Cité Administrative ocupa uma área estabelecida em trinta e dois (32) hectares declarados de utilidade pública pelo Decreto de 25 de maio de 2012, revogando o Decreto de 2 de setembro de 2010 expropriando o centro histórico de Porto Príncipe. O perímetro da área contará mais de quarenta (40) edifícios públicos, espaços comerciais e escritórios para instituições internacionais (UCLBP, 2012). Segundo a UCLBP, os projetos de requalificação do centro de Porto Príncipe seguem três (3) objetivos estratégicos: 1) promover intercâmbios e coordenação entre as instâncias centrais de planejamento das políticas públicas do Estado; 2) criar uma massa crítica para dinamizar a administração pública; 
3) afirmar claramente o desejo de reconstruir a capital haitiana dentro da sua dimensão histórica. Portanto, um é projeto nacional que se baseia em diretrizes de gestão exigentes desenvolvidas pela UCLBP, descrevendo sete (7) áreas específicas. Este é um grande empreendimento que terá que levar em conta outros três decretos adotados em junho de 2012: que delimitam o centro histórico, a área de preservação no litoral e da área do Champs de Mars (praça dos heróis da independência do Haiti).

\section{Figura 3 - Projeto de requalificação urbana/cidade administrativa}

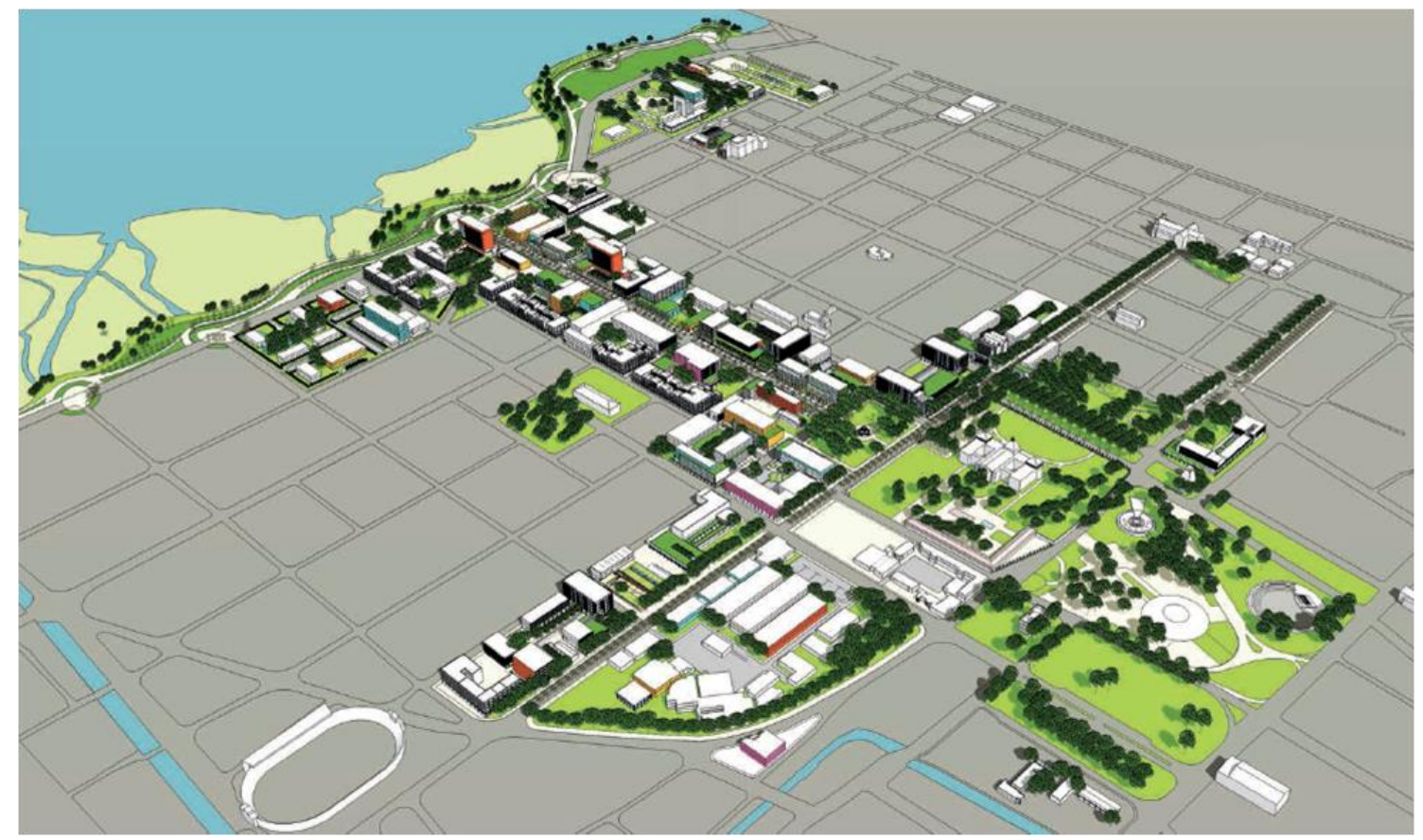

Fonte: UCLBP, 2012

A figura 3 apresenta o perímetro urbano do Plano Diretor da Cidade Administrativa no contexto da reconstrução do centro histórico de Porto Príncipe. Isso está gerando uma recomposição da paisagem urbana tanto física quanto arquitetônica. Apresenta-se, uma nova morfologia urbana e a transição por novas relações sociais com os lugares no centro. Contudo, a cidade de Porto Príncipe é uma só e multifuncional. Nesse sentido, o Plano Diretor da cidade pode dar importância apenas à função administrativa? Com efeito, o déficit habitacional sempre foi um problema crônico na cidade de Porto Príncipe e no Haiti como um todo, que depois do terremoto se agravou ainda mais. Desse modo, por que este projeto de requalificação urbana de Porto Príncipe não leva em conta a questão habitacional? Nessa direção, desvendamos que o projeto de reconstrução do centro histórico reforça as desigualdades socioespaciais na metrópole marginalizando, assim, os grupos historicamente menos favorecidos na estrutura urbana 
da metrópole. Tudo isso, sob o duplo selo da ilegalidade de seu status de ocupação do espaço e da proximidade do centro do poder do Estado. A expropriação e a operação de expulsão de famílias de baixa renda e de elementos da classe média no contexto da reconstrução do centro histórico cujo número não é revelado mostram claramente que o projeto de requalificação urbana da cidade Porto Príncipe é excludente.

Nesse sentido, a operação de expropriação e de expulsão da área que delimitada o perímetro da Cidade Administrativa prosseguem objetivos de prestígio e simbólico do Estado. Tudo isso pode ser explicado pela saída de famílias pobres e de atividades informais no centro, uma forma de reapropriação do espaço urbano ao longo prazo expulsando as populações pobres para as áreas periféricas. Em síntese, há uma lógica de acesso desigual a essa centralidade que se desenvolve na reconstrução do centro histórico de Porto Príncipe. Dessa maneira, o Estado como estrategista considera que não pode deixar seu centro do poder ser invadido pelos pobres e suas atividades informais de todos os tipos. Ele propõe reservar o centro histórico da cidade para instituições públicas, internacionais e os estratos sociais que possuem condições suficientes para acessá-lo e criar outras áreas para os "excluídos".

Por conseguinte, o objetivo do projeto não é reduzir a desigualdade socioespacial e a pobreza urbana, mas sim a dispersa na aglomeração. Em nossa opinião, o projeto de requalificação urbana do centro da cidade pós-desastre cria essa dispersão na região metropolitana pela partida forçada dos pobres e de alguns elementos da classe média do centro histórico para áreas periféricas e vulneráveis. Como já vimos anteriormente, a emergência e a expansão de Canaan no grande Porto Príncipe é um exemplo concreto em que os grupos sociais menos favorecidos do centro histórico estão reprimidos em bairros precários mal equipados em termos de equipamentos e de estruturas urbanas. Portanto, a dinâmica das desigualdades socioespaciais historicamente construídas em Porto Príncipe passou a ser mais visível entre os grupos que produzem o espaço. Desvendamos, na atualidade que a reconstrução em andamento teria legitimado a distância entre os grupos sociais de poder aquisitivo alto e baixo, ao invés de sobrepor ou misturá-los. A nosso ver, o terremoto de 2010, apesar de que ser trágico em termos de perdas de vida e de destruição oferece oportunidades para reconstruir uma cidade socioespacialmente mais justa. Todavia, assistimos após a catástrofe de 2010, a um aumento das desigualdades socioespaciais marcadas pela urbanização de novas áreas na metrópole pelas populações que, de alguma forma, foram expulsas no contexto do processo de reconstrução do centro histórico de Porto Príncipe. 


\subsection{Avaliação da implementação do projeto de requalificação urbana do centro de}

\section{Porto Príncipe: Cidade Administrativa de 2012}

Desde 2012, está sendo implementado pelo governo haitiano o projeto de requalificação urbana do centro de Porto Príncipe denominado Cidade Administrativa. Nesse sentido, dez (10) anos após a passagem do terremoto e, oito (8) anos depois, a implementação desse projeto se encontra num impasse. Isso pode ser notado pela quantidade de obras finalizadas, em andamento e em fase de análise. Dentro das obras previstas no âmbito da realização do referido projeto no pós-catástrofe apresentamos, por meio de imagens, algumas delas.

\section{Figura 4 - Vista parcial do centro da cidade de Porto Príncipe em 2017}

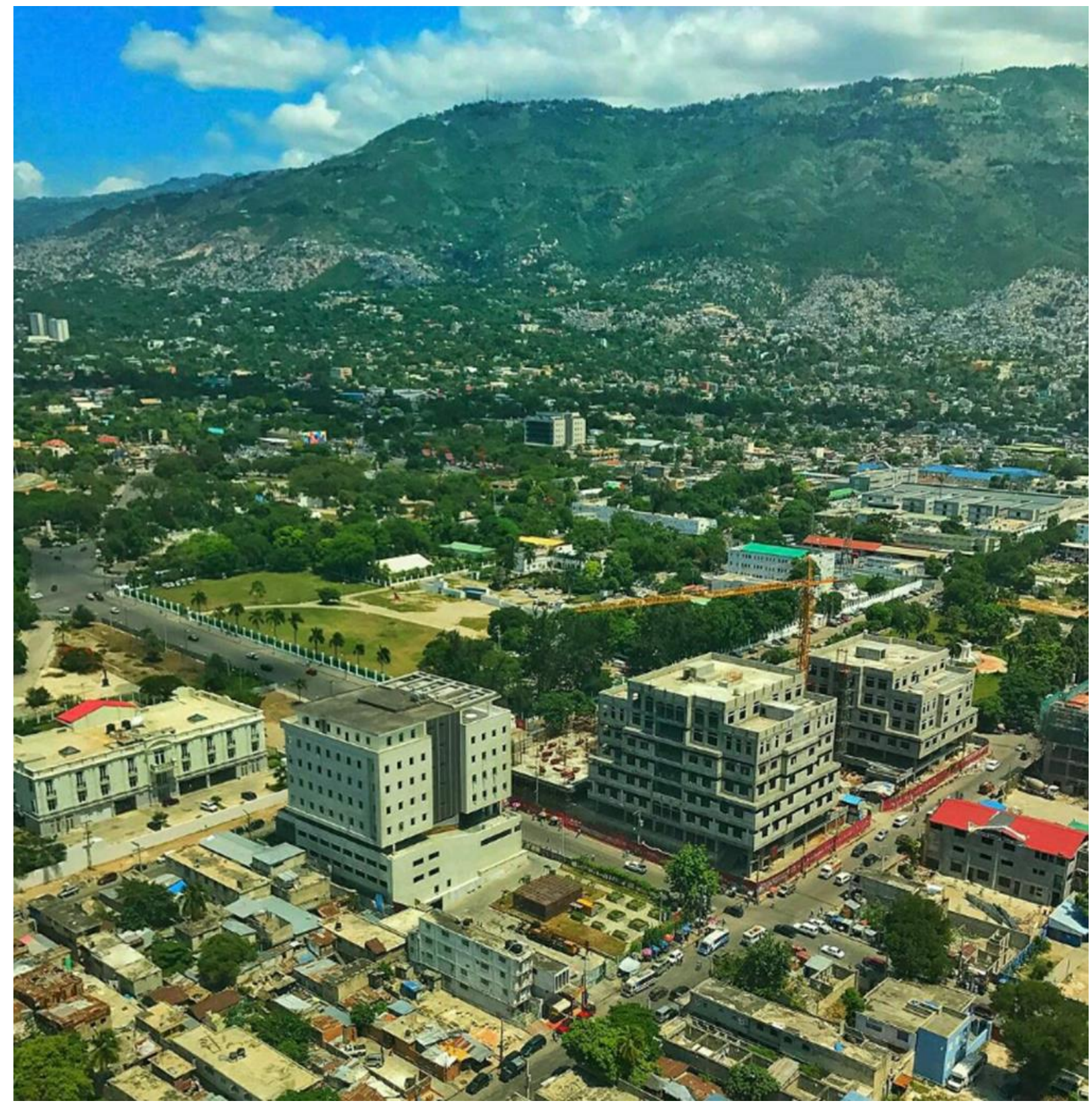

Fonte: Money, 2017 
A figura 4 apresenta a vista parcial do centro de Porto Príncipe em 2017, com algumas obras em construção próxima da Praça Champs de Mars, patrimônio do centro de Porto Príncipe, onde se realiza as manifestações culturais e políticas no Haiti.

Figura 5 - Renovação e ampliação do Quiosque Occide Janty

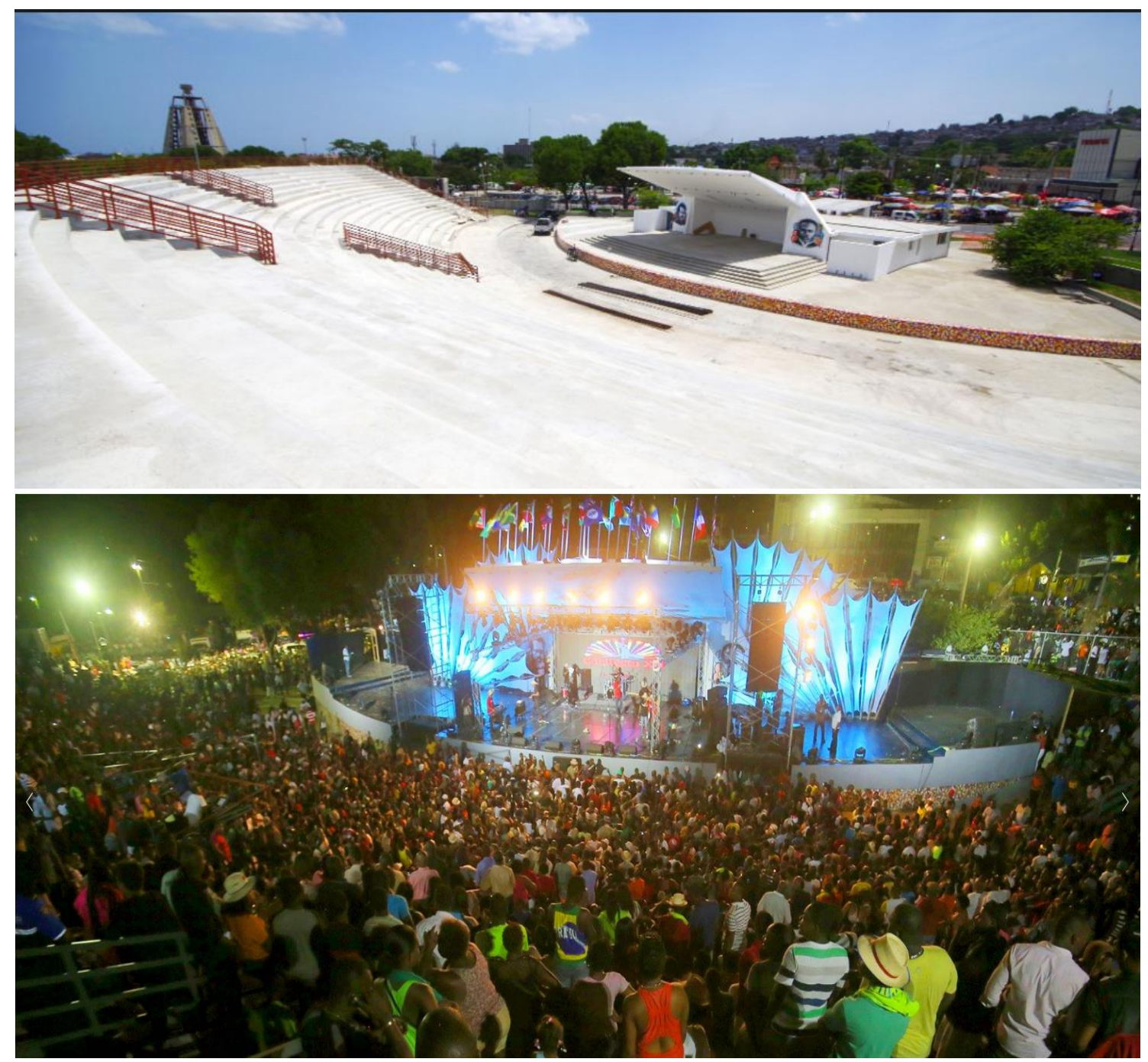

Fonte: Lamy, 2015

A figura 5 mostra a renovação e a ampliação do Quiosque Occide Janty em Champs de Mars que faz parte da implementação do projeto de requalificação urbana do centro da cidade. Esse espaço cultural e artístico possui duas principais funções seguintes: as manifestações culturais e políticas. Esse quiosque é uma homenagem ao notável músico haitiano Occide Jeanty (1860-1936). Ele tem um novo anfiteatro de cerca de 5.000 lugares com esplanada, lojas e restaurantes. De uma área de $7.000 \mathrm{~m}^{2}$, o quiosque renovado custa cerca de US \$ 3,8 milhões através do financiamento público do programa PetroCaribe. Foram inauguradas, em 2015, as obras foram realizadas por uma empresa de construção haitiana e supervisada por UCLBP. 
Com efeito, no mesmo objetivo da implementação do projeto de requalificação urbana do centro da cidade, a primeira obra a ser inaugurada no perímetro urbano da Cidade Administrativa foi o edifício da Corte Suprema de Porto Príncipe. Esse tribunal é a mais alta corte da República do Haiti, constitucionalmente fundada, em 1817.

Figura 5 - Corte Suprema em Porto Príncipe

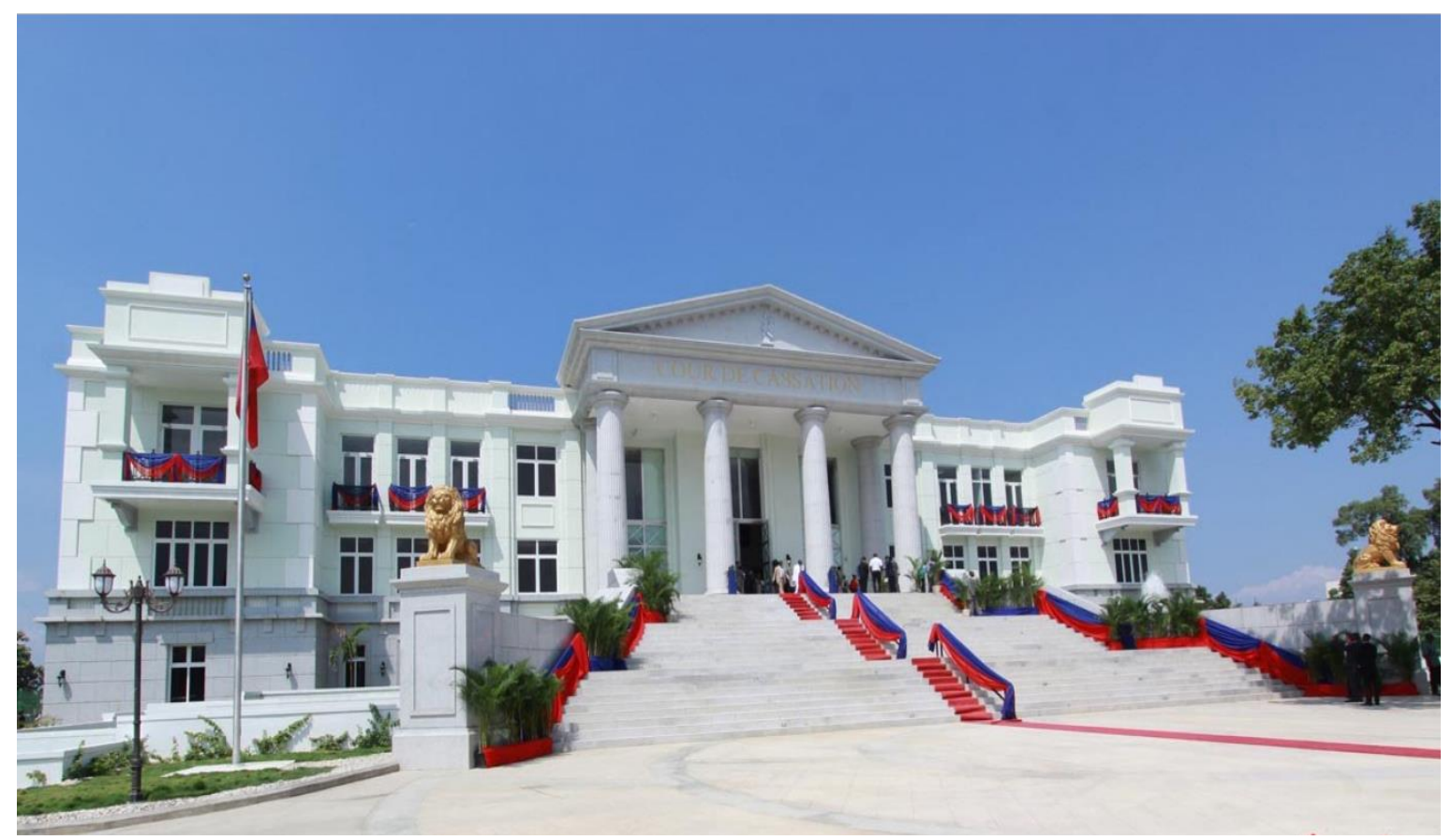

Fonte: Weche, 2016.

Em agosto de 2013, foram iniciadas as obras de construção do novo edifício do Tribunal de Supremo de Porto Príncipe e foi inaugurada em 14 de julho de 2015, no governo de Joseph Michel Martelly (2011-2016). O edifício foi construído pela empresa de construção China- taiwanesa Overseas Engineering \& Construction Corporation LTDA. S.A. (OECC). Essa mesma empresa é responsável por vários projetos de infraestrutura, incluindo estradas, no Haiti. Em uma área de $4.262 \mathrm{~m}^{2}$, o edifício possui três níveis, dois elevadores, jardim, tendo sido construído de acordo com padrões sísmicos, segundo a Unidade de Construção de Habitação e Edifícios Públicos (UCLBP), responsável da supervisão da obra. Do ponto de vista de financiamento, a primeira obra do projeto da Cidade Administrativa foi financiada através de apoio do governo China-Taiwan, no montante de cerca de US\$ 15 milhões $^{26}$, ou seja, foi por meio de apoio externo ou bilateral, o que não honra a maioria dos haitianos que vivem em um dos países mais corruptos do mundo.

26 Mais informações disponíveis em: https://lenouvelliste.com/article/118922/15-millions-pour-laconstruction-de-la-cour-de-cassation. Acesso em: 8 de maio de 2019. 
Figura 6 - Ministério do Interior e das Coletividades Territoriais

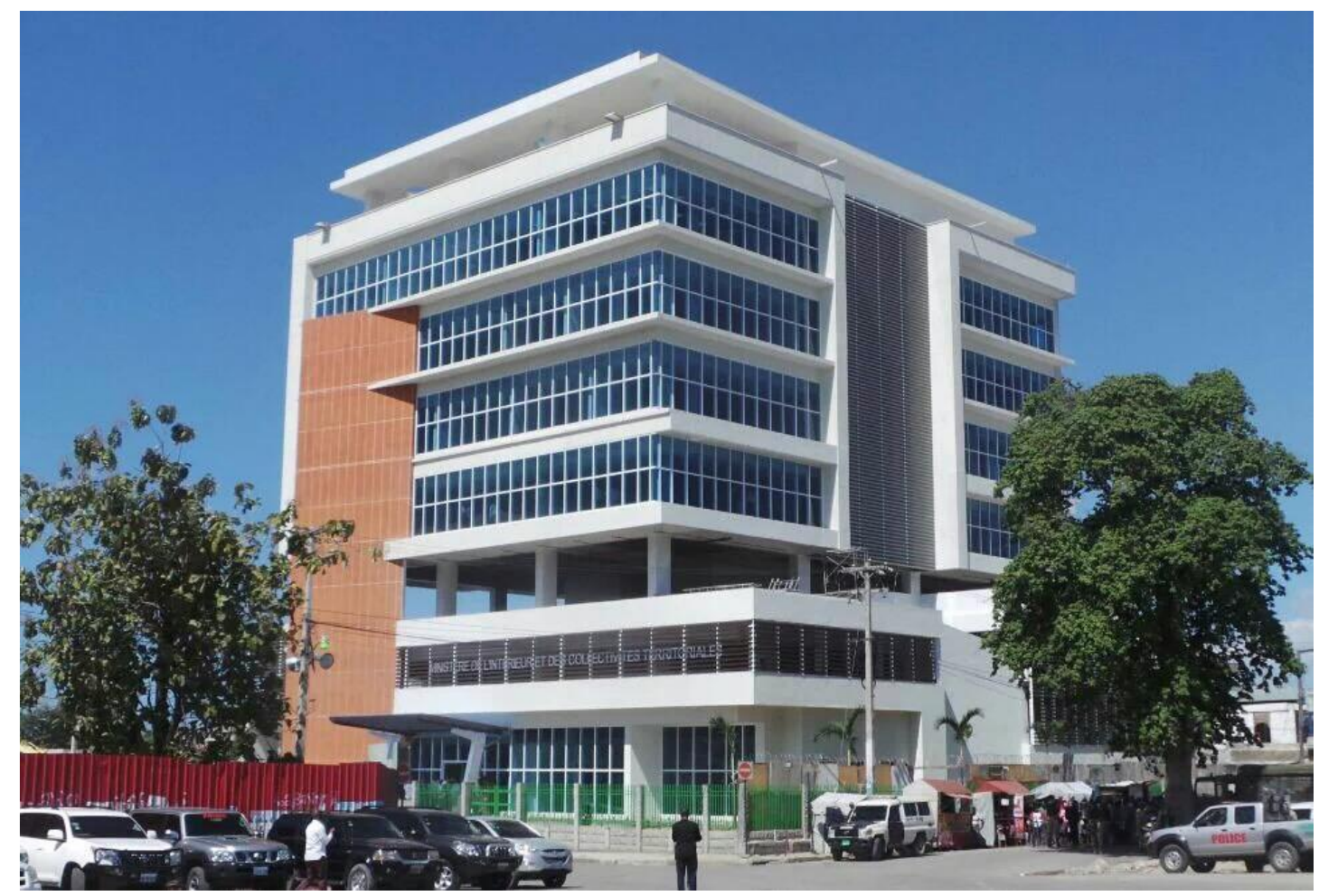

Fonte: trabalho de campo, 2017.

A Figura 6 mostra o edifício do Ministério do Interior e das Coletividades Territoriais (MICT), de 8 andares, quatro pisos de estacionamento que podem acomodar mais de uma centena de veículos e um café de terraço de desembarque adicional. Construído em um terreno de $8.500 \mathrm{~m}^{2}$, o novo prédio do MICT atualmente abriga as direções e serviços decentralizados no território nacional e foi inaugurado em 2016.

A obra é servida por duas escadas, dois elevadores e uma rampa de acesso de entrada para pessoas com mobilidade reduzida. Além dos locais de trabalho, há uma área de jardim na parte interna. O custo de construção é estimado em US\$17,5 milhões de financiamento público ${ }^{27}$. As empresas de execução são Overseas Engineering \& Construction Corp. LTDA. S.A "(OECC) da China-Taiwanesa e a Constructora ROFI, da República Dominicana. O contratado principal foi do MICT, com o gerente de projeto delegado pela Unidade de Construção de Habitação e Edifícios Públicos (UCLBP).

27 Mais informações disponíveis em: https://www.haitilibre.com/article-23083-haiti-reconstruction-lenouveau-batiment-du-ministere-de-l-interieur-est-enfin-pret.html Acesso em: 20 de maio de 2019. 


\section{Figura 7 - Corte Superior de Contas e Contencioso Administrativo}

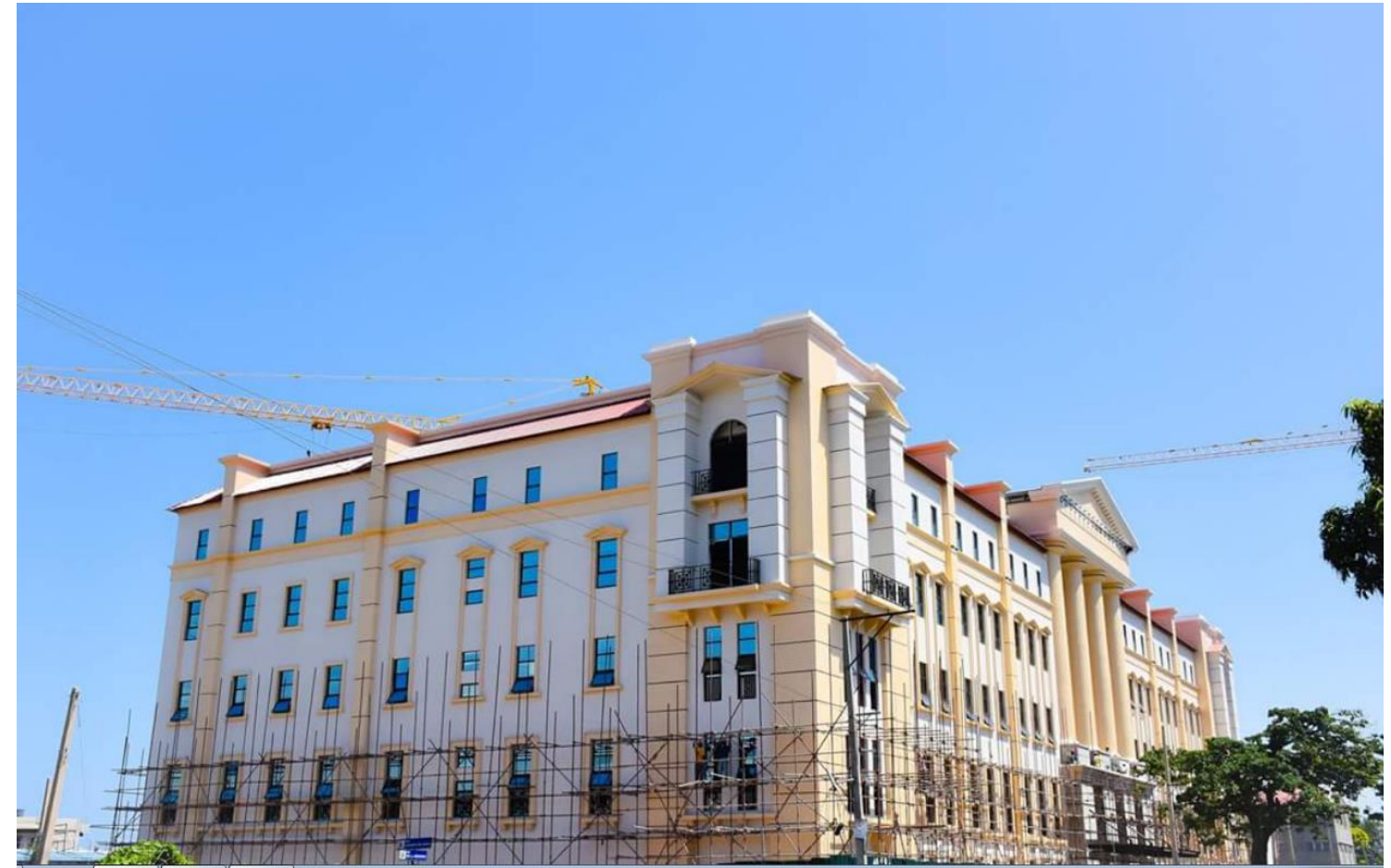

Fonte: Money, 2018

A figura 6 mostra o edifício da Corte Superior de Contas e Contencioso Administrativo que ocupa uma área $13.092 \mathrm{~m}^{2}$, com 6 níveis, incluindo estacionamento e jardim. A execução da obra está sendo feita pela empresa Hongyuan Construction Company Limited, da China que ganhou o concurso sob a supervisão da firma de engenheiros consultivos da ESC, tendo o MEF como contratante principal e como gerente de projeto delegado para a Unidade de Construção de Habitações e Edifícios Públicos (UCLBP). A construção da obra é financiada por US\$ 27 milhões ${ }^{28}$, fundos do cancelamento da dívida externa do Haiti pelo Fundo Monetário Internacional (FMI) após o terremoto de 2010. 


\section{Figura 8 - Ministério da Economia e Finanças}

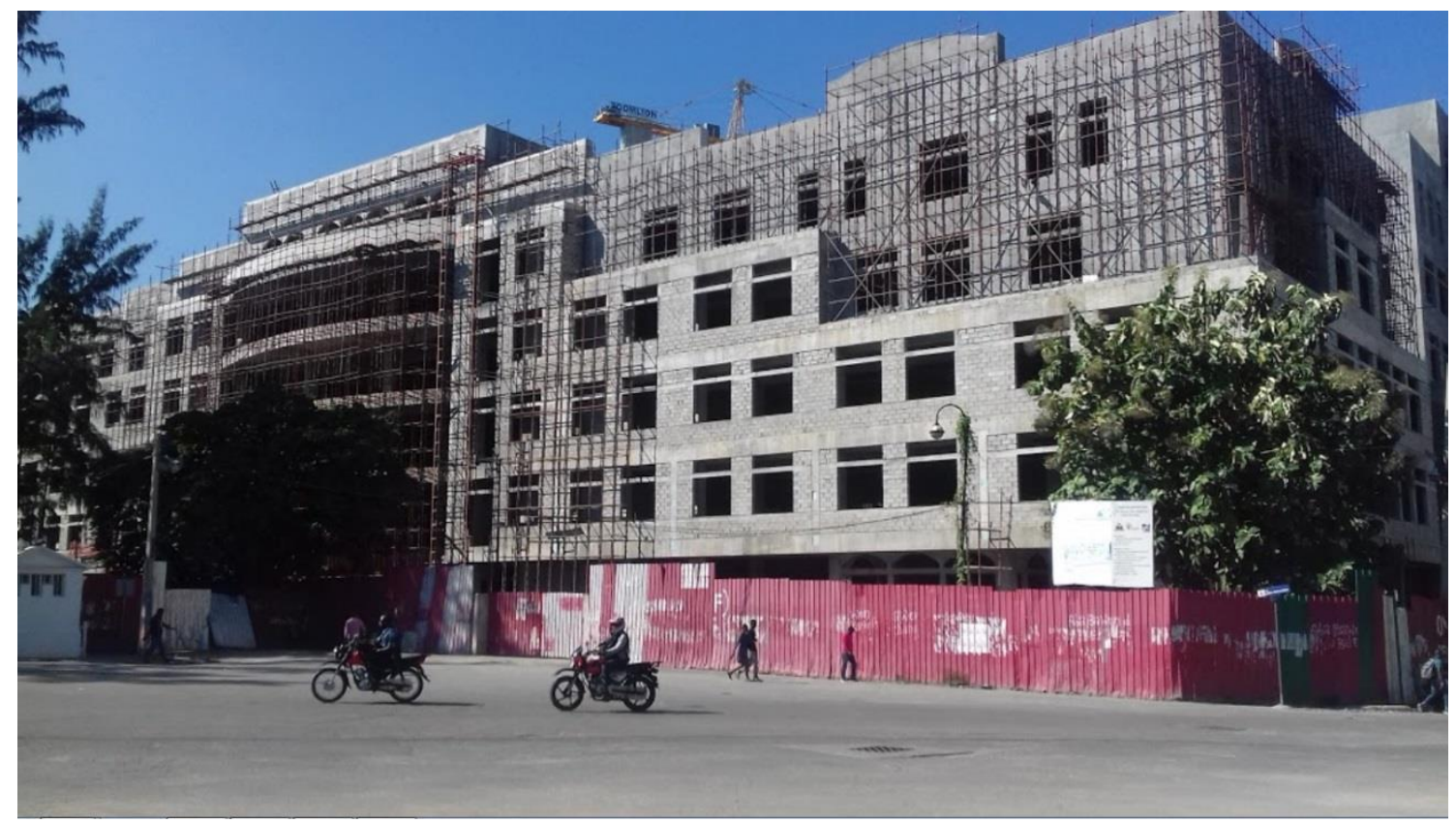

Fonte: Trabalho de campo, 2017.

A figura 8 mostra a construção em andamento desde 2014, do ministério da Economia e Finanças que na verdade é um conjunto de três edifícios públicos que abrigam o Ministério da Economia e Finanças (MEF), Administração Geral das Alfândegas (AGD) e Direção Geral de Impostos (DGI). Os edifícios estão sendo construídos numa área $21.665 \mathrm{~m}^{2}$ incluindo piso térreo, seis (6) andares, dois (2) níveis de estacionamento. Com uma capacidade de 798 pessoas, o edifício da AGD, que será construído em $9.332 \mathrm{~m}^{2}$, incluindo seis (6) níveis. O edifício da DGI será construído em $12.469 \mathrm{~m}^{2}$ de sete (7) andares, além do térreo. Os edifícios seerão equipados com todos os confortos para o funcionamento de escritórios, ar condicionado, banheiros, refeitório, salas de conferência e refeitório (UCLBP, 2014).

Financiado pela UCP (Unidade de Coordenação de Projetos) com recursos resultantes do cancelamento da dívida pública do Estado do Haiti pelo FMI, após a catástrofe de 2010. A construção desses três edifícios faz parte do vasto projeto de requalificação urbana do centro histórico, e a Cidade Administrativa está sendo erguida na área do centro histórico e patrimonial de Porto Príncipe, com elevadores e escadas de emergência, em cada um desses edifícios. As abras estão sento construídas pela empresa de construção Hongyuen Construction Company Limited, da China. 


\section{Figura 9 - Ministério do Comércio e da Indústria}

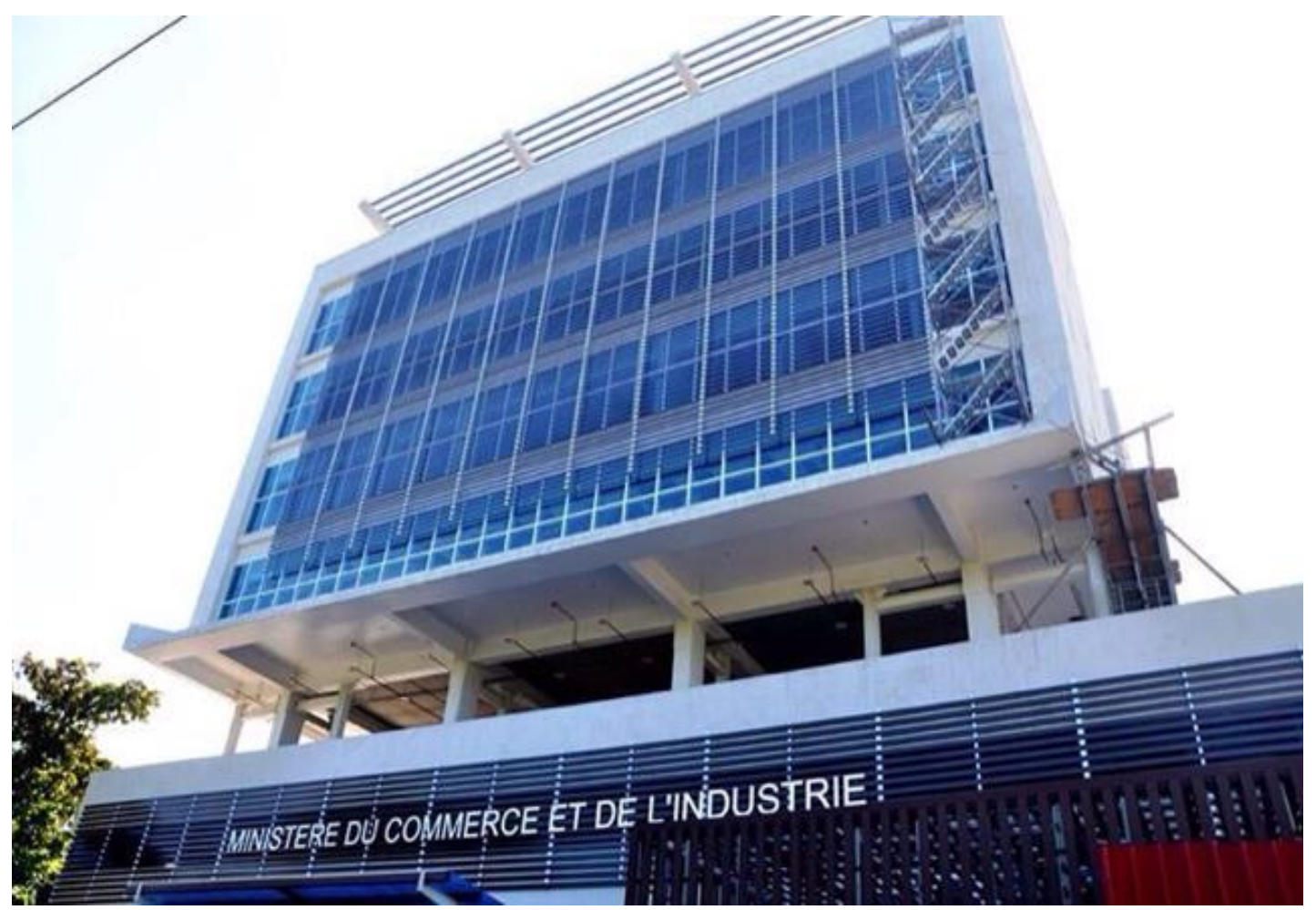

Fonte: Money, 2017.

A figura 9 é o edifício do Ministério do Comércio e da Indústria (MCI) que tem o objetivo de promover a criação de empresas, o comércio, a industrialização do país; o fortalecimento do controle de qualidade sobre os produtos; a proteção do consumidor e o estabelecimento de um sistema de rastreabilidade. O edifício foi construído pela empresa de construção Hadom Contrutora, da República Dominicana financiado pelo dinheiro público, no valor estimado a US\$ 10 milhões (UCLBP, 2016).

Nessa dinâmica de reconstrução ou da implementação do projeto de requalificação urbana de Cidade Administrativa observamos que as empresas de construção internacionais despenham papeis importantes. Tudo isso pode ser notado pela "ausência" de empresas construtoras nacionais que não se beneficiaram os grandes contratos de construção ${ }^{29}$ alegando suas incapacidades técnicas, financeiras e as exigências internacionais. Já que o sistema bancário haitiano não permite que as empresas de construção nacionais obtenham títulos sem garantias o que não contribui, a nosso ver, para o fortalecimento das empresas nacionais de construção. Contudo, partimos da ideia de que há desenvolvimento socioeconômico em um país quando este

29 Mais informações disponíveis em :

https://lenouvelliste.com/lenouvelliste/article/140377/Construction-SOS-des-firmes-haitiennes. Acesso em: 30 de maio de 2019. 
último possui um setor privado dinâmico e engajado. Nesse sentido, pode-se dizer, de alguma forma, que o setor privado no Haiti não se envolve no processo de reconstrução da cidade de Porto Príncipe, e do país como o todo no contexto do pós-terremoto de 2010. Tudo isso indica, como veremos no segundo capítulo da dissertação, que no Haiti existe um setor privado que controla e monopoliza as atividades econômicas atuando nas atividades de importação, mas não de produção. Nessa direção, o Haiti é considerado pela maioria desses atores econômicos nessas atividades de importações como um espaço para fazer negócio, acumular riquezas, portanto, sem preocupação para um desenvolvimento socioeconômico real do Haiti.

O setor de construção é importante no crescimento econômico no contexto de reconstrução de um país. Entretanto, no caso do Haiti após o desastre de 2010, esse setor está sendo controlado por empresas transnacionais. Desse modo, podemos dizer que é uma situação que não acarreta consequências para a economia do país, considerando o lugar estratégico que desempenha o setor de construção que está entre aqueles setores capazes de criar empregos e o crescimento econômico tão esperado no Haiti. No entanto, as autoridades governamentais haitianas escolheram empresas da República Dominicana, da China e da China-Taiwan. Cabe destacar, na maioria dos casos, sobretudo, com as empresas da República Dominicana os contratos foram assinados por acordo em violação das leis e das regras gerais de execução de contratos públicos. Esses instrumentos jurídicos estabelecem os limiares para a adjudicação de contratos públicos, respectivamente publicados no jornal oficial do Estado Le Moniteur em 12 de junho e 9 de setembro de 2009. Tudo isso em um esquema suposto de corrupção dessas empresas com as autoridades governamentais haitianas, sobretudo, durante o governo de Joseph Michel Martelly, entre 2011 e 2016.

Com efeito, a problemática da corrupção que identificamos como um dos fatores das desigualdades sociais no Haiti é discutido no segundo capítulo deste trabalho. Portanto, veremos que a conjugação desse fator com o processo de urbanização que ocorre de uma forma acelerada a partir de 1980, multiplicaram as desigualdades socioespaciais na metrópole no período contemporâneo. Isso é demostrado ao longo deste primeiro capítulo no contexto pós-terremoto de 2010 , em particular, com a emergência e a expansão de Canaan como novo espaço de reprodução da vida na metrópole no âmbito da urbanização acelerada do país. À vista disso, analisaremos essa urbanização como produtora das desigualdades socioespaciais em Porto Príncipe, no próximo capítulo desta Dissertação de Mestrado. 


\section{A URBANIZAÇÃo DO HAITI E A CENTRALIZAÇÃO EM PORTO PRÍNCIPE DE 1980 ATÉ HOJE}

\subsection{O processo da expansão urbana da cidade de Porto Príncipe}

Este terceiro capítulo da Dissertação tem como objetivo analisar a urbanização acelerada do Haiti, com enfoque no processo de centralização em Porto Príncipe no período de 1980 até a atualidade. Durante essa década ocorreu um conjunto de processos político, econômico e social que contribuíram para a centralização em Porto Príncipe. Ademais, ele faz ver o processo da expansão urbana da cidade; a problemática da centralidade, as desigualdades socioespaciais diante da questão habitacional, de renda, problemas de transporte e da mobilidade urbana. Propõe-se, também, uma análise da economia haitiana de 1980 ao período atual com destaque na economia urbana da cidade de Porto Príncipe inspirada da teoria dos circuitos da economia urbana proposta por Milton Santos (2008), sem, portanto, usar a noção de circuitos superior e inferior da economia urbana.

O Haiti enquanto país subdesenvolvido inserido na periferia do capitalismo conhece um processo de urbanização tardio. Nesse contexto, o início da centralização em Porto Príncipe é evidenciado na primeira metade do século XX. Isso é demostrado nos estudos de Desvauges (1954) e Corvington (1991), em que Porto Príncipe e seu entorno tinha uma população apena de 120.000 habitantes no começo do século passado quando o país sofreu a intervenção estadunidense, entre 1915 e 1934. Já Suzy Castor (1987) sinaliza que a cidade, até o início dessa intervenção norte-americana, era "uma grande vila" (Ibidem, p. 42). Dingan' Bazabas (1997, p. 29), por sua vez, aponta que esse período marca a supremacia absoluta da cidade de Porto Príncipe dentro do conjunto de cidades haitianas. É nesse contexto que a capital haitiana experimenta a concentração populacional, incluindo suas áreas periféricas fundidas ao que é chamado hoje a Região Metropolitana de Porto Príncipe (RMPP) ${ }^{30}$.

Desse modo, quase todos os investimentos públicos foram alocados para a construção de infraestruturas, como edifícios administrativos e indústrias, instaladas ao

30 Ressaltamos que, de fato, a Região Metropolitana de Porto Príncipe (RMPP) não possui status legal especial. A lei de 19 de setembro de 1982 trata da regionalização, sob o nome de Distrito metropolitano de Porto Príncipe com municípios de Porto Príncipe, Petion-ville, de Croix-des-Bouquets, Gressier e os distritos de Carrefour, Delmas e Croix des Missions. A operacionalidade do Distrito Metropolitano foi mais tarde definida pela lei de 1983 que criava a Comunidade Urbana de Porto Príncipe. Este último foi revogado por decreto em 1989. A Região metropolitana de Porto Príncipe considerado é o atual espaço composto por municípios de Porto Príncipe, Petion-Ville, Delmas, Carrefour, Cité Soleil e Tabarre (HAITI, 1989). 
redor da cidade de Porto Príncipe. A partir desse momento se iniciou, portanto, o fenômeno da desigualdade espacial em termos de distribuição das atividades produtivas em relação às outras cidades haitianas. Por conseguinte, pode-se dizer que essas medidas de uso e de apropriação do espaço urbano de Porto Príncipe foram tomadas de acordo com os interesses estadunidenses em detrimento do país. Segundo Castor (1987, p. 22), a centralização dos investimentos na cidade Porto Príncipe foi reforçada durante a ocupação americana do Haiti, devido ao desenvolvimento da indústria e do capital dos Estados Unidos no início do século XX, que buscava matérias-primas do Haiti (carvão, ferro, cobre), além de oportunidades de investimentos do capital no país. Conforme aponta Milton Santos (1979):

Um país subdesenvolvido é uma Formação Socioeconômica dependente, um espaço onde o impacto das forças externas é preponderante em todos os processos. Por esse motivo, sua organização espacial é dependente. Essas forças externas têm sua própria lógica que é interna às instituições e às empresas interessadas, mas externa em relação aos países a que pertencem. As instituições e empresas que impõem inovações técnicas ou organizacionais têm um motivo comum- a acumulação de capital, mesmo que cada agente tenha sua própria maneira de operar (SANTOS, 1979, p. 30).

Nesse sentido, os Estados Unidos da América no seu projeto hegemônico, geoeconômico e intervencionista se baseou em um conjunto de medidas políticas e administrativas no Haiti. Tudo isso, pode ser constatado quando esses sujeitos colocaram seus colaboradores haitianos ${ }^{31}$ no poder, mas quem governava naquele período eram eles. Dessa maneira, houve eliminação dos orçamentos municipais em benefício de um orçamento nacional, bem como o fechamento da maioria dos portos regionais mais importantes que foram abertos ao comércio exterior criou tarifas preferenciais em Porto Príncipe. Ademais, se criou uma força policial com hierarquia militar, a Guarda do Haiti com sede na capital; houve a supressão das autoridades locais (ANGLADE, 1982, BAZABAS, 1997). Por conseguinte, esses mecanismos de centralização replicam pesados impostos no final da primeira metade do século XX e no início da segunda metade do mesmo, pelos governos haitianos (CASTOR, 1987). Portanto, isso levou à concentração de investimentos em infraestruturas que não se enquadravam num projeto de desenvolvimento nacional incluindo outras cidades regionais dentro do território nacional. 
Na mesma ideia do processo de centralização em Porto Príncipe em 1949, a cidade passava por um processo de requalificação urbana devido à organização da Exposição Universal de 1949, a "Exposition internationale du bicentenaire de Port-auPrince". Esse evento é uma feira mundial que aconteceu em Porto Príncipe de $1^{\mathrm{o}}$ de dezembro de 1949 a 8 de junho de 1950 na ocasião do bicentenário da fundação da cidade em 1749, por colonizadores franceses.

\section{Figura 10 - Obras de requalificação urbana pela Exposição de 1949}

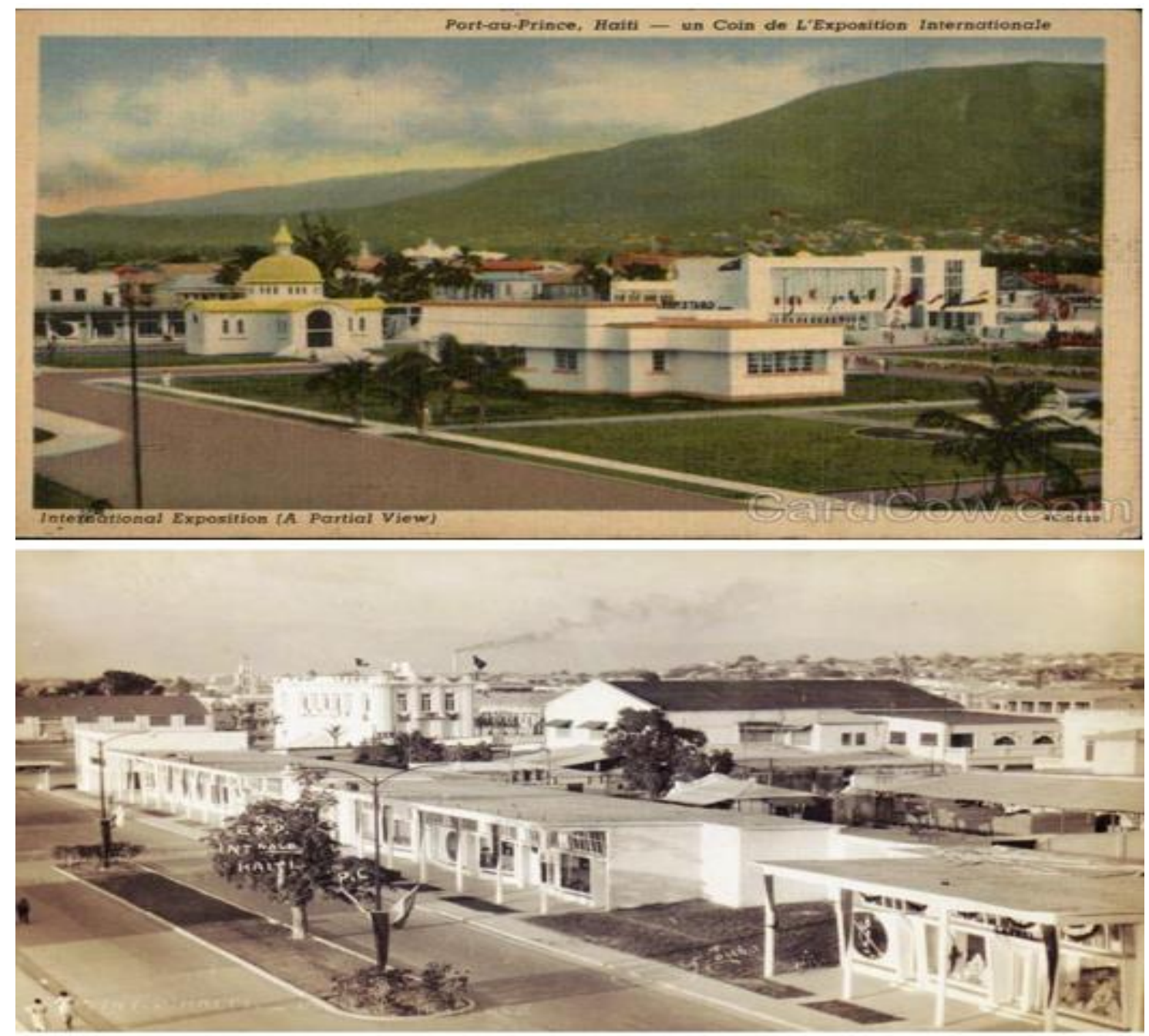

Fonte: Catalogue officiel de l'exposition d'Haïti, 1949: 23. Publicité de la compagnie aérienne américaine Pan America World Airways, 1949. Archive en ligne, Université de Floride. Acesso em: 20 de jul. de 2018.

Com efeito, a Exposição Universal, cujo tema é "The Festival of Peace" (O Festival da Paz, tradução livre na língua portuguesa), teve como objetivo de intensificar as relações internacionais após a Segunda Guerra Mundial. No entanto, o então presidente do Haiti de 1946 a 1950, Léon Dumarsais Estimé, pretendia, de acordo com Pierre Etienne (2012), desenvolver a indústria turística no Haiti mostrando ao mundo a 
verdadeira face do país; superando, pois, os seus estereótipos sociais, em que imagens externas mostram um país atrasado. O evento, também, foi uma oportunidade para mostrar a cultura haitiana ao mundo. Nesse sentido, a área da Exposição havia mais de uma dúzia de hotéis construídos no acompanhamento do projeto da requalificação urbana do sítio em uma extensão de 24 hectares ao longo do litoral. O arquiteto de Nova York, August Ferdinand Schmiedigen, propõe o plano geral do projeto requalificação da área de Exposição na cidade depois de seu trabalho para as Exposições Mundiais de Paris de 1937 e de Nova York em 1939 e 1940.

Com efeito, as obras e as infraestruturas construídas na ocasião da Exposição contribuíram para o processo de "embelezamento" da metrópole de Porto Príncipe com a construção do boullevard Harry Truman, de mais de $2 \mathrm{~km}$ ao longo do litoral, em honra do Presidente dos Estados Unidos Harry S. Truman. A área planejada pelo evento é conhecida como a Cité de l'Exposition. Os prédios antigos foram demolidos para dar lugar a jardins e parques com paisagem verde na baía do mar que se transformou em um espaço de negócios modernos (HOLLY, 1999 p. 19). Em que sentido esse evento contribuiu na melhoria das condições de vida da população urbana? As instalações de equipamentos da Exposição ${ }^{32}$ traziam atrações na cidade foi o caso da área para apresentações folclóricas que foram realizadas no Théâtre de Verdure juntamente com outros eventos e shows. Segundo Anthony Georges Pierre (2012):

O presidente Dumarsais Estimé mostrou grande liderança ao ter uma visão de longo prazo para o desenvolvimento do Haiti. Havia ética e competência no modo de operação dos outros líderes da época, e ainda mais porque os projetos nunca eram improvisados, e metodicamente preparados. Finalmente, sob a presidência do Estime, havia uma vontade coletiva de mudar e aspirar ao progresso. Sob esta presidência, o país desfrutou de um bom clima democrático e a Exposição Internacional de Porto Príncipe, em 1949, foi uma bênção para o Haiti, no que diz respeito ao embelezamento e saneamento de uma enorme área da capital que liderou o boom econômico que impulsionou e, especialmente, o desenvolvimento da indústria do turismo que foi muito importante até a década de 1960 (GEORGES PIEERE, 2012, p. 130).

32 Catalogue de l'exposition internationale, 1949-1950, Bi-centenaire de Port-au-Prince 1749-1949, 1948, Édition tirée à 200 exemplaires, University of Florida, Digital Library of the Caribbean: http://ufdc.ufl.edu/AA00010663/00001 Acesso em: 20 de out. de 2018. 
Figura 11 - Centro de Porto Príncipe e o Théâtre de Verdure em 1949

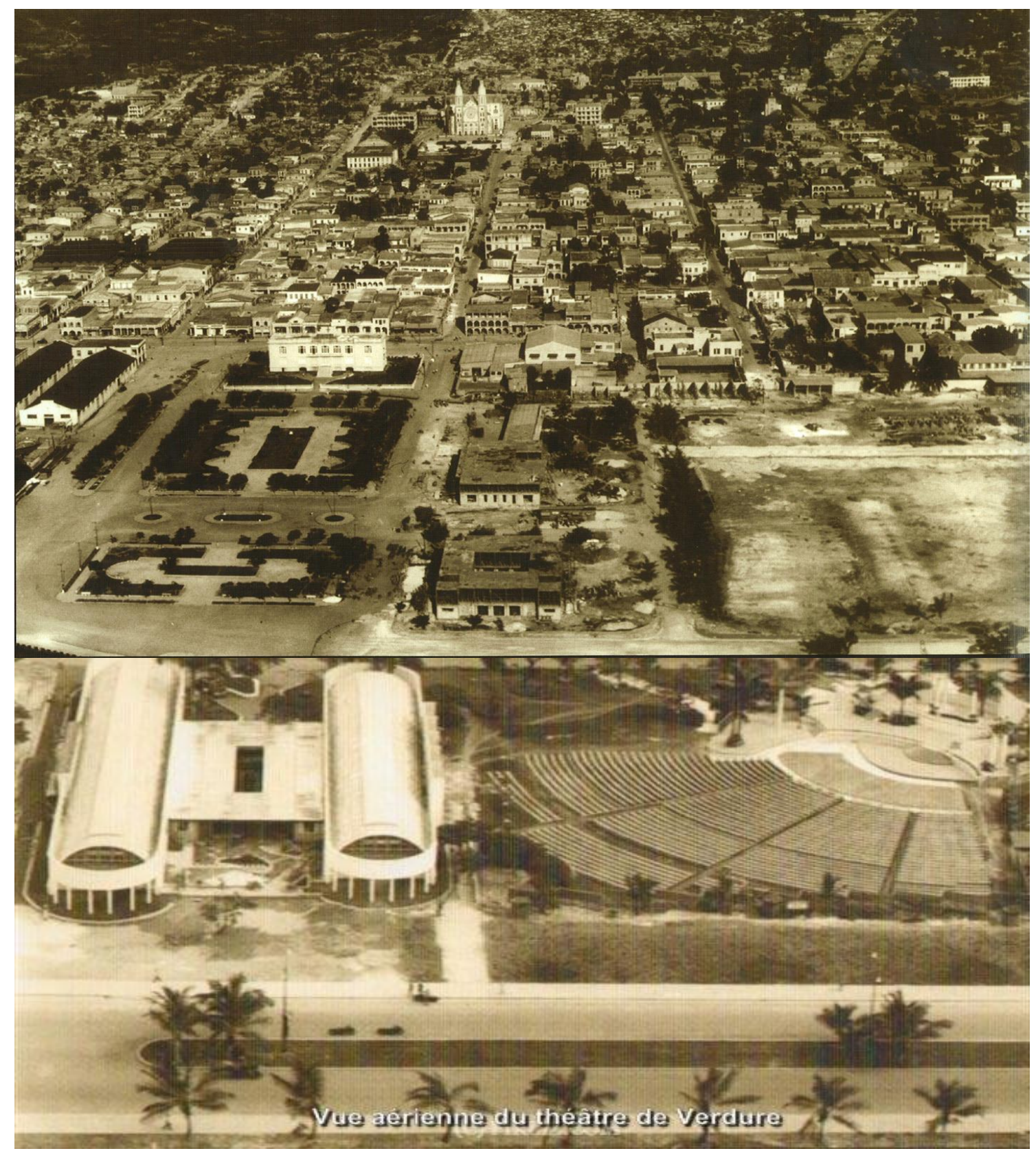

Fonte: Catalogue officiel de l'exposition d'Haïti, 1949 :23. Publicité de la compagnie aérienne américaine Pan America World Airways, 1949. Archive en ligne, Université de Floride. Acesso em: 20 de jul. de 2018.

As atividades do evento começaram em 8 de dezembro de 1949, com as exposições nacionais na área de entretenimento, e, em 12 de fevereiro de 1950, foram montados pavilhões oficiais internacionais de países convidados como EUA, Canadá, México, Panamá, Uruguai, Chile, Venezuela, Cuba, França, Itália, Espanha, São Martino, Bélgica, Líbano, Síria e Palestina. Segundo Pierre Etienne (2012, p. 35), a Exposição pretendia fazer da cidade de Porto Príncipe, a capital cultural da América. Por isso, na ocasião do evento, inúmeros artistas internacionais foram convidados, entre 
os principais foram Dizzy Gillespie, Miles Davis, a cantora de salsa cubana Celia Cruz, o cantor portoriquenho Daniel Santos, o compositor haitiano Frantz Casseus e o cantor cubano Bebo Valdés. Foi convidada, também, a ópera nacional de Nova York, além dos mestres do Teatro alla Scala e do cantor americano Marian Anderson. Porém, no encerramento da Exposição, em 8 de junho de 1950, o balanço desse evento internacional não foi significativo, na medida em que os visitantes foram cerca de 4 milhões, menos que foi previsto. Desta forma, esse número de visitantes não permitiu a recuperação do investimento público nas obras de requalificação urbana que foi de US\$ 1 milhão, equivalente a três quartos do orçamento anual do Haiti naquela época. Consequentemente, as fortes críticas deram origem a um golpe de estado em maio de 1950, que depôs o presidente Estimé (GEORGES- PIERRE, 2012).

No entanto, as obras de requalificação urbana executadas em 1949, na ocasião da Exposição Universal de Porto Príncipe, marcaram a estrutura urbana atual da metrópole, no sentido de que a área planejada pela realização desse evento internacional foi centralizada num determinado lugar da cidade, marcando, mesmo depois do evento, a morfologia urbana da metrópole na contemporaneidade. Por exemplo, a construção da rodovia de Delmas que faz a ligação ao município de Petion-Ville. Isso permite uma transformação na cidade de Delmas evidenciada a partir de 1970 quando se torna uma grande banlieue residencial para a "classe média" (HOLLY, 1999). Com a urbanização, a cidade de Carrefour que era um bairro, em 1982, por Decreto se tornou município revelando a formação da conurbação já no final dos anos de 1970.

Com efeito, no decorrer da urbanização, particularmente, duas décadas após a realização da Exposição Universal na cidade ocorreu, um fenômeno migratório de forma lenta de habitantes das áreas rurais para cidades em busca de trabalho, de centros educacionais, administrativos e econômicos; com sua visão da capital haitiana. Essa mobilidade espacial da população em direção à metrópole pode ser entendida, de alguma forma, por um conjunto de medidas tomadas durante o regime totalitário e ditatorial de François Duvalier (Papa Doc), entre 1957 a 1971, apoiado pelos Estados Unidos da América no âmbito da sua luta ideológica contra o regime comunista cubano. Nesse período, Duvalier ordenou o fechamento dos portos das cidades provinciais o que reforça ainda mais a centralização em Porto Príncipe (BASABAS, 1997).

Contudo, conforme aponta o geógrafo haitiano Anglade (1990), o Haiti conhece o processo de urbanização tardio em relação a outros países latino-americanos. No início dos anos 1980, países da América Latina e do Caribe se aproximaram do limiar 
de $50 \%$ de urbanização, enquanto que o Haiti atinge apenas $20 \%$. Ou seja, até a década de 1970 , cerca de $80 \%$ da população haitiana vivia no campo, e a economia do país se baseou na agricultura tanto pelo consumo nacional como para a exportação de produtos agrícolas (arroz, feijão, milho). Com efeito, estimou-se que 500.000 habitantes $^{33}$ no momento da proclamação da independência, em 1804, atingindo 1 milhão de habitantes em 1850 e 2 milhões em 1900 (IHSI, 1950). Em meados do século XX a população ultrapassou a cifra de 3 milhões de habitantes segundo dados do censo de 1950. Em menos de um quarto de século os dados do censo de 1971 mostraram que a população haitiana passou a marca de 4 milhões de habitantes (IHSI, 1971). Nos dois últimos censos, de 1982 e 2003, respectivamente, indicaram que a população do Haiti é de 5.053 .190 e de 8.373 .750 habitantes $^{34}$; já em 2018 a população total é estimada em onze (11) milhões de habitantes (IHSI, 2018).

Gráfico 4 - Crescimento da população haitiana entre 1804 a 2010

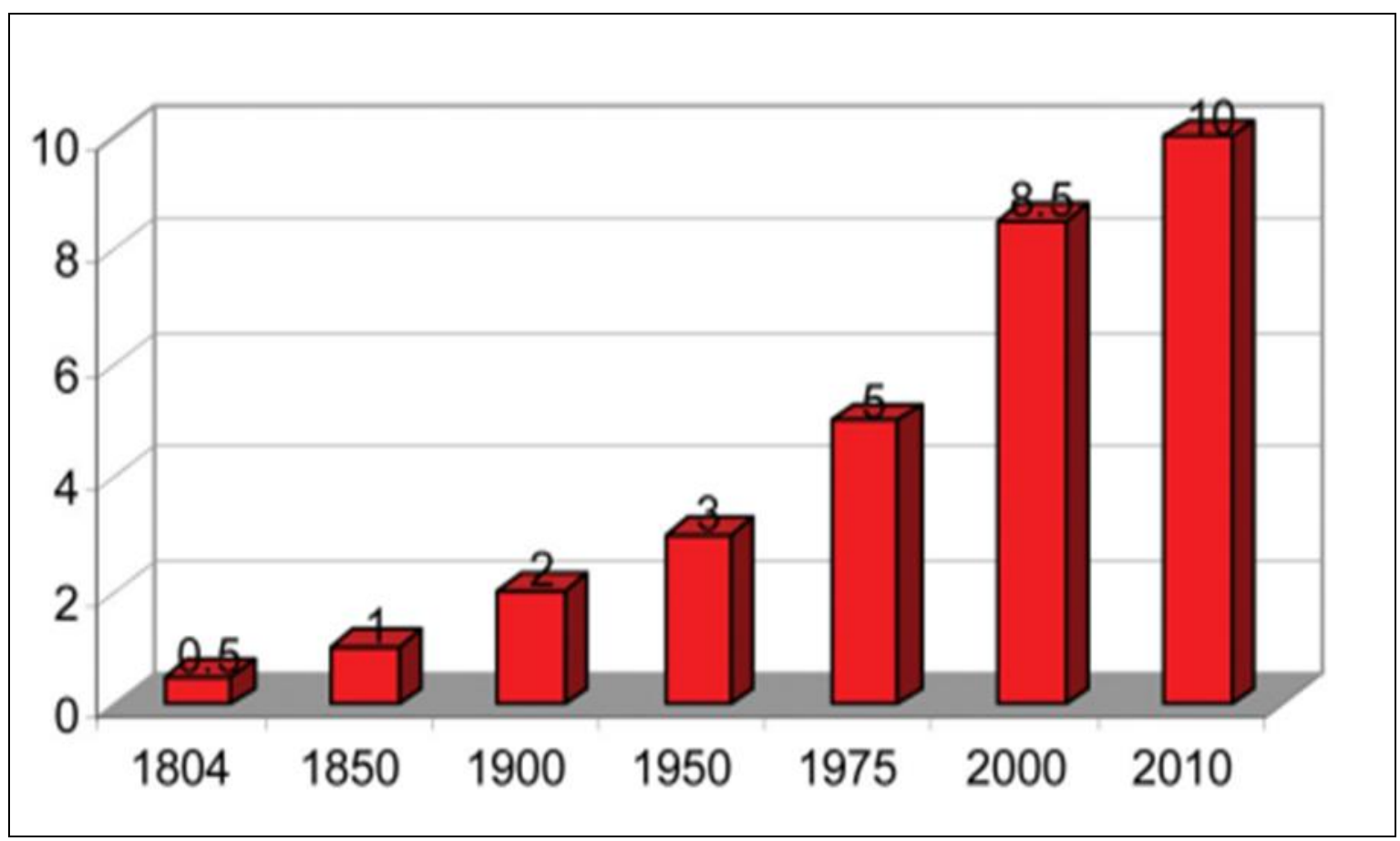

Fonte: IHSI, 2010

O gráfico 4 apresenta o crescimento da população total do Haiti entre 1804 a 2010. Mencionamos que em termos de composição étnica cerca de $95 \%$ dos haitianos é descendente de escravizados negros vindo da África durante o período do comércio triangular entre os séculos XVI e XVIII para trabalhar nas plantations da colônia 
francesa de São Domingos. Bem no momento quando o levante dos "escravos", de 1791, levou ao fim a sociedade escravocrata de São Domingos havia mais de meio milhão de negros; dois terços dos quais nascidos na África ${ }^{35}$. Naquela época, a população branca era estimada em cerca de 40.000 pessoas. A perda de vidas durante o período revolucionário (1791-1804), com emigrações e massacres que se seguiram aos primeiros meses da independência do Haiti, levou à "erradicação total dos brancos"36.

Com efeito, o referido gráfico chama atenção visto o crescimento da população haitiana que, a partir da década de 1950, cresce de forma significativa. Entretanto, em termos de distribuição da população nas cidades dentro do território nacional, isso a partir de 1990, encontramos no conjunto das cidades do Haiti 133 cidades que representava de cerca de $25 \%$ da população total. Já a região metropolitana de Porto Príncipe, concentrava $55 \%$ da população urbana, onde existe a maior parte dos investimentos públicos, privados e de infraestruturas básicas do país.

Para Prévil (2008, p. 44), a nível nacional, a taxa de urbanização foi de cerca de 47\%, em 2008. Com o aumento da população urbana, e por decisão do Estado, houve o fenômeno da fragmentação ${ }^{37}$ da cidade de Porto Príncipe (SALGUEIRO 1998). Em 1980, com a ascensão no entorno de Porto Príncipe de cidades com características rurais tiveram status de municípios, por meio da criação dos conselhos de Carrefour e de Delmas, em 1982, e de Tabarre e Cité Soleil, em 2003. Isso aumenta o número de entidades de municípios sem trazer, nessa direção, melhorias nos serviços sociais prestados aos cidadãos. Ao contrário, a iniciativa reduziu a capacidade de ação da Prefeitura do Município de Porto Príncipe (NOEL, 2012).

35 São dados obtidos nos diferentes arquivos sobre os negros que vieram dos territórios da África Ocidental e Central que eram de diferentes tribos, grupos étnicos, e de línguas diferentes (PIERRE, 2014). 36 Os raros brancos que sobreviveram a esse período foram os regimentos do General Francês, Leclerc. Ou seja, os poloneses que desistiram das fileiras da expedição militar de Bonaparte para se juntarem à guerra da independência. Desejando permanecer no Haiti após a independência, eles foram reconhecidos como cidadãos haitianos pela Constituição Imperial de maio de 1805. A ligação entre estes poloneses e negros deu origem a "mestiço" cujos vestígios ainda são encontrados hoje em diferentes lugares espalhados pelo país: em Cazal, norte de Porto Príncipe; no Sudeste, no vale de Jacmel; em Fonds des Blancs, no vilarejo de Baleine; em Port-Salut e Saint Jean du Sud no Sul do país (PIERRE, 2014).

37 Salgueiro $(1998$, p.41) afirma que com a fragmentação do espaço urbano há o surgimento de uma nova configuração na lógica interna das cidades. SALGUEIRO, T, B. Cidade Pós-Moderna: espaço fragmentado. Território, Rio de Janeiro, Ano III, n. ${ }^{\text {4 }}$, p.39-54, jan-jun 1998. 
Gráfico 5 - Tendência demográfica da população haitiana entre 1950 a 2012

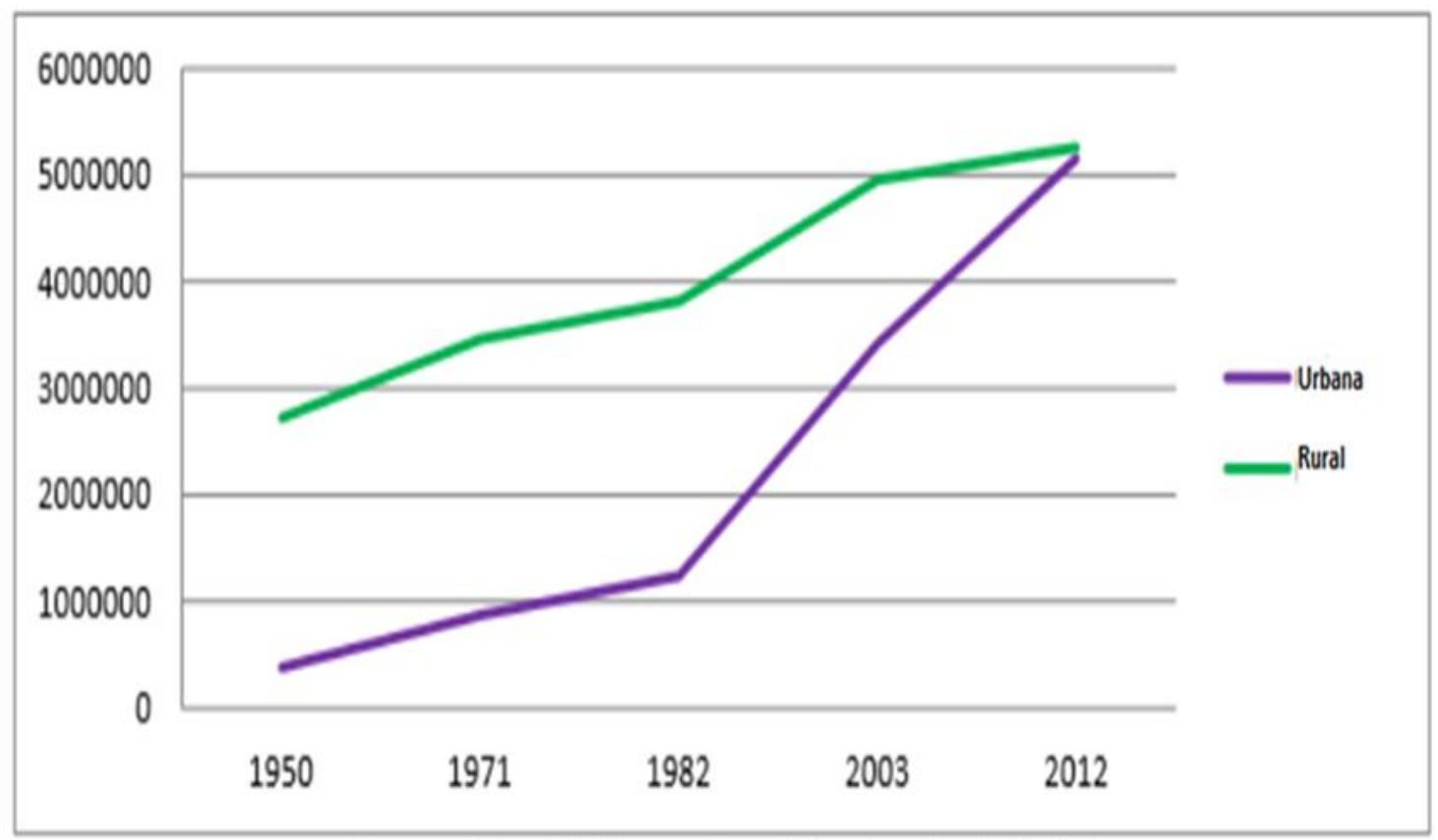

Fonte: IHSI, 2003

O gráfico 5 apresenta a tendência demográfica da população haitiana, onde se observa que a população rural cresce menos entre 1950 a 2012. Entretanto, se constata um crescimento acelerado da população urbana de 1980 até nos dias de hoje. Portanto, a população rural diminui. Isso evidencia o processo de urbanização acelerado que o país passa; de forma semelhante a alguns outros países subdesenvolvidos, em que o processo ocorre de modo rápido em comparação aos países desenvolvidos, como mostra o estudo de Santos (1980) em A Urbanização Desigual ${ }^{38}$. Dessa maneira, a cidade de Porto Príncipe e a sua região metropolitana é o espaço em que se recebe o maior fluxo de migrantes internos devido à centralização das atividades econômicas ali. Dados do IHSI mostram em 1950, cerca de $10 \%$ da população do país vivia na área urbana, mas desde essa década até 1980, o número de moradores urbanos aumentou quatro vezes a mais que a taxa da população rural. Assim, durante essa última década a população urbana cresceu a uma taxa mais rápida do que a população total, atingindo $30 \%$ de meados da década de 1990 aos anos de 2000 (IHSI, 2003).

38 Milton Santos. Urbanização Desigual: A Especificidade do Fenômeno Urbano nos países subdesenvolvimentos. Vozes, 1980 
Tabela 1 - Distribuição da população haitiana por região, superfície e densidade em 2010

\begin{tabular}{|c|c|c|c|c|c|}
\hline Departamento & População & $\begin{array}{l}\text { População } \\
\text { urbana }\end{array}$ & $\begin{array}{l}\text { População } \\
\text { rural }\end{array}$ & $\begin{array}{l}\text { Superfície } \\
\text { em km² }\end{array}$ & Densidade $/ \mathrm{km}^{2}$ \\
\hline Oeste & 3724441 & 2887875 & 836566 & 4982,6 & 747 \\
\hline Sudeste & 584681 & 81989 & 502992 & 2034,1 & 287 \\
\hline Norte & 986334 & 458057 & 528277 & 2115,2 & 466 \\
\hline Nordeste & 364123 & 162290 & 201833 & 1622,9 & 224 \\
\hline Artibonite & 1596659 & 628839 & 967820 & 4886,9 & 327 \\
\hline Centro & 689705 & 128769 & 560936 & 3487,4 & 198 \\
\hline Sul & 716269 & 150013 & 566256 & 2653,6 & 270 \\
\hline Grand'Anse & 432826 & 93916 & 338910 & 1911,9 & 226 \\
\hline Noroeste & 673599 & 173038 & 500561 & 2102,9 & 320 \\
\hline Nippes & 316577 & 52880 & 263697 & 1267,8 & 250 \\
\hline Total & 10085214 & 4817666 & 5267548 & 27750,3 & 373 \\
\hline
\end{tabular}

Fonte: IHSI, 2010. Organização dos dados: Ismane Desrosiers, 2019.

A tabela 1 evidencia a distribuição da população haitiana por Departamento (região), tanto a nível urbano como rural; nela se vê o tecido geográfico do território haitiano. Além da densidade demográfica dos habitantes por quilômetros quadrados observamos, de um lado, que o Departamento Oeste concentra maior população, sem dúvida. Isso se deve à localização da cidade de Porto Príncipe, que historicamente tem papel preponderante no contexto urbano junto ao território nacional. Por outro lado, o Departamento dos Nippes possui a menor população em 2010. Portanto, é uma distribuição desigual da população através do território nacional. Constatamos, ainda, que a densidade demográfica varia consideravelmente de acordo com os Departamentos. Por exemplo, $747 \mathrm{hab} / \mathrm{km}^{2}$ no Departamento de Oeste diante de 224 hab $/ \mathrm{km}^{2}$ do Departamento do Nordeste (IHSI, 2010). 
Tabela 2 - Dados demográficos dos municípios da RMPP em 2009.

\begin{tabular}{llll}
\hline Municípios & População & Superfície & Densidade demográfica de ha $/ \mathrm{km}^{2}$ \\
\hline Porto Príncipe & 850.000 & $36.04 \mathrm{~km}^{2}$ & 34637 \\
\hline Petion-Ville & 415.000 & $165.5 \mathrm{~km}^{2}$ & 8260 \\
\hline Delmas & 354.000 & $27.74 \mathrm{~km}^{2}$ & 12958 \\
\hline Carrefour & 275.000 & $165.2 \mathrm{~km}^{2}$ & 19691 \\
\hline Cité Soleil & 237.000 & $21.81 \mathrm{~km}^{2}$ & 11052 \\
\hline Tabarre & 117.000 & $24.47 \mathrm{~km}^{2}$ & 4391 \\
\hline Total & 2.248 .000 & $440.76 \mathrm{~km}^{2}$ & 15106 \\
\hline
\end{tabular}

Fonte: IHSI, 2009. Organização dos dados: Ismane Desrosiers, 2019.

A tabela 2 faz ver os dados demográficos dos municípios que constituem a região metropolitana de Porto Príncipe, em que se observa que Porto Príncipe possuiu uma alta densidade demográfica em 2009. Porém, essas municipalidades da região metropolitana não têm estruturas para controlar seu desenvolvimento espacial e atender as demandas de serviços básicos da maior parte de seus habitantes. Isso leva a efeitos negativos, tais como: alta concentração da população urbana, predominância de bairros pobres, insegurança, congestionamento das redes de transporte urbano, ambiente degradado e insalubre, problemas de saneamento básico. Pode-se dizer, de alguma forma, que com o processo de urbanização do país as oportunidades e os serviços básicos que se desenvolvem não correspondem às pressões da população, sendo que as cidades, nesse sentido, não conseguem atender às demandas dos recém-chegados. Entretanto, dentro dessa dinâmica de dados do IHSI assinalou que em 2008, a taxa de urbanização das cidades da região metropolitana de Porto Príncipe é maior em relação ao resto do país.

Com efeito, buscando entender o crescimento populacional na cidade através da mobilidade espacial. Para isso, baseamos em uma amostra de 112 moradores que entrevistamos, durante o nosso trabalho de campo em 2017. Nesse sentido, as entrevistas têm como objetivo em saber a origem (lugar de nascimento) desses moradores, em que os resultados mostram que o Departamento Oeste apresenta, onde se localize a metrópole tem maior porcentagem em nível se senso, alcançando $19 \%$ por cento da população entrevistada. Por outro lado, o Departamento do Centro conta com a 
menor porcentagem, $4 \%$ por cento vivem na cidade, mas, que nasce no interior do país como indica o gráfico 6.

\section{Gráfico 6 - Origem dos moradores entrevistados na RMPP}

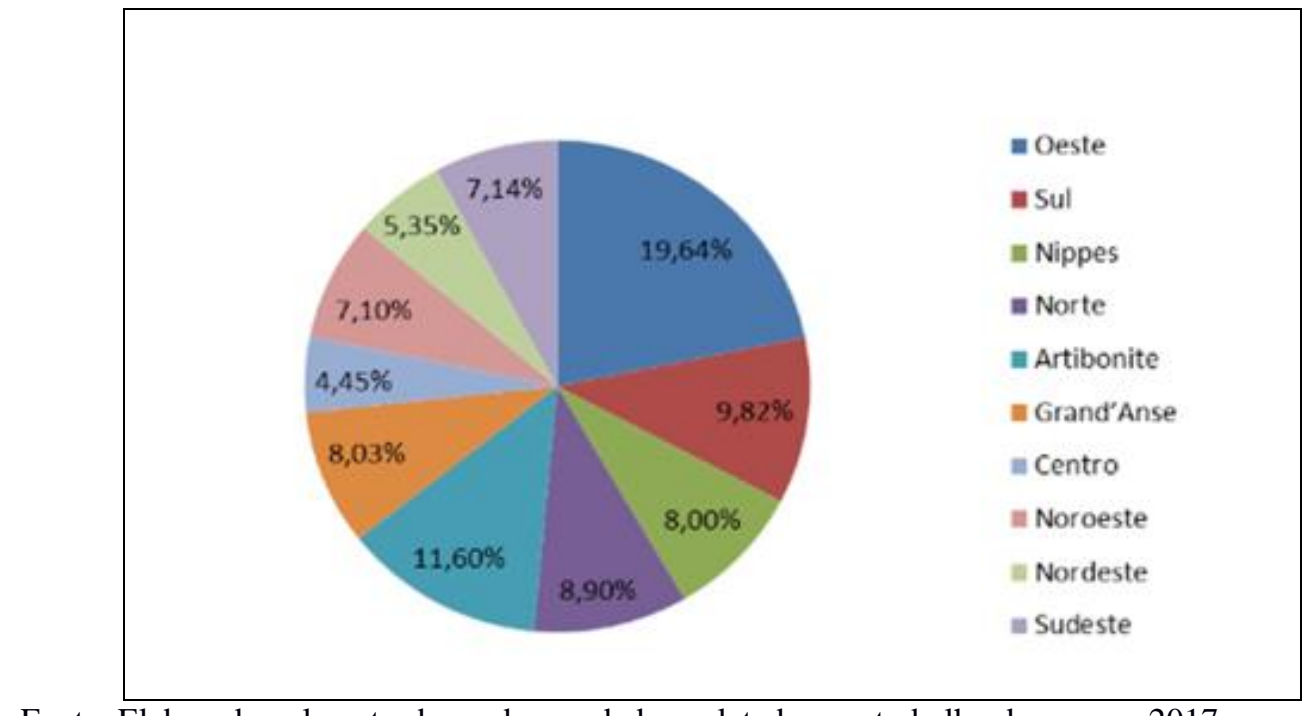

Fonte: Elaborado pelo autor baseado nos dados coletados em trabalho de campo, 2017.

\section{Gráfico 7 - População total entrevistada na RMPP}

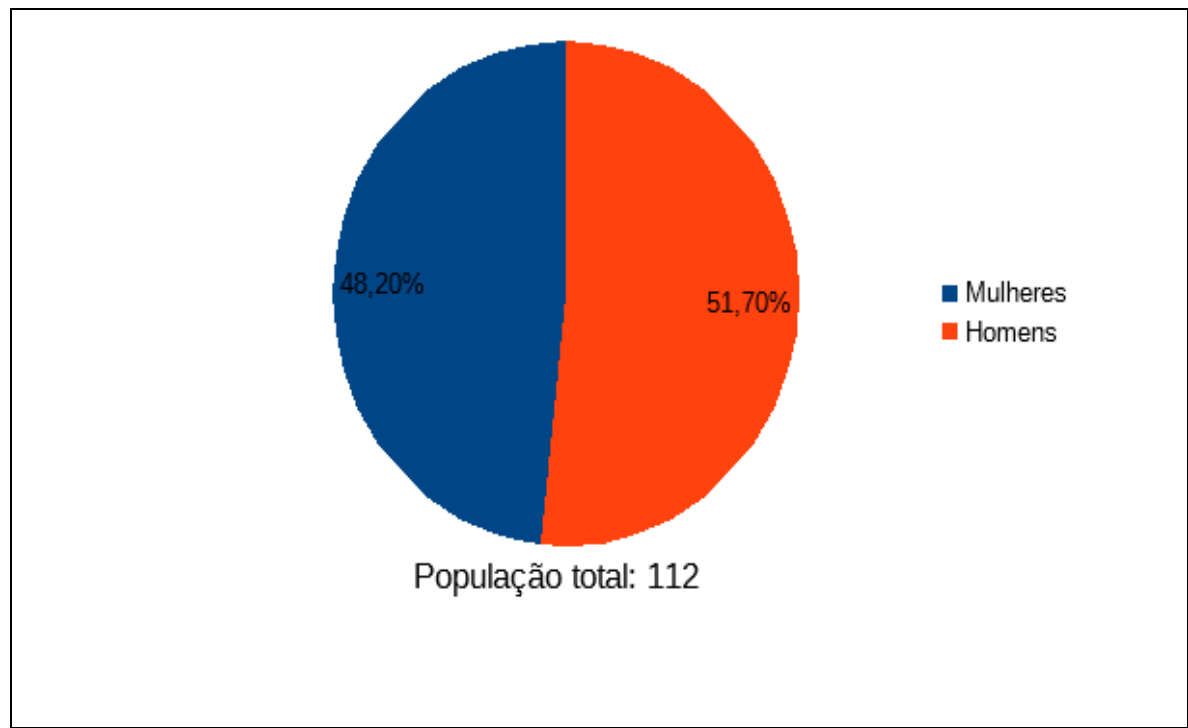

Fonte: Elaborado pelo autor baseado nos dados coletados em trabalho de campo, 2017.

O gráfico 6 indica a origem dos moradores entrevistados na cidade de Porto Príncipe no âmbito da realização do trabalho de campo em 2017. O gráfico 7, por sua vez, apresenta o número de pessoas entrevistadas na região metropolitana de Porto Príncipe. A porcentagem de homens foi ligeiramente maior, na medida em que os homens apresentam 51,70\%, por cento dos entrevistados enquanto que as mulheres apresentaram 48,20\%; sendo que nessas variantes os chefes de famílias margeiam o percentual de idade entre 35 e 60 anos. 


\section{Gráfico 8 - Crescimento da populacional da RMPP de 1950 a 2005}

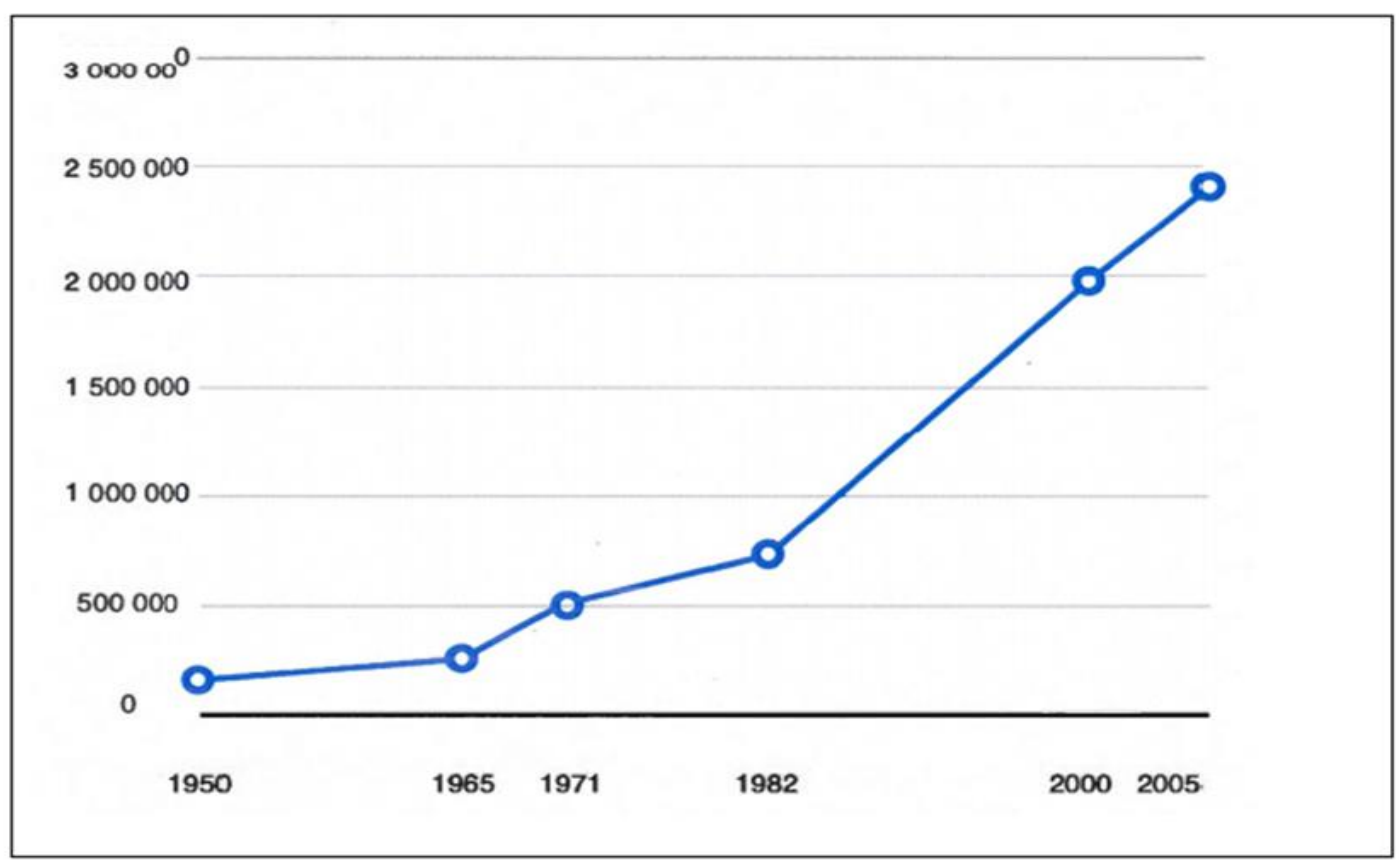

Fonte: IHSI, 2003 apud CEPAL, 2008.

O gráfico 8 apresenta o crescimento da população na região metropolitana de Porto Príncipe, em que se observa que a população cresce substancialmente de 1950 a 2005. Essa tendência continua até ao presente momento. Isso evidencia o fenômeno da urbanização acelerado que o país, em que uma percentagem elevada da população vive na cidade, embora os serviços básicos de saneamento, de transportes e de acesso à habitação de qualidade não acompanhem o mesmo ritmo da taxa de crescimento da população urbana. No entanto, segundo Milton Santos (1979):

As explicações do fenômeno da urbanização variam. Todas, porém, giram em torno de fatores como o comportamento demográfico, o grau de modernização e de organização dos transportes, o nível da industrialização, os tipos de atividades e relações que mantêm com os grupos sociais envolvidos, a criação e retenção local do valor adicionado, a capacidade local para guardar uma maior ou menor parcela da mais valia gerado, o grau de redistribuição da renda entre os produtores, os efeitos diretos ou indiretos da modernização sobre a política, a sociedade, a cultura e a ideologia (SANTOS, 1979, p.38).

Para Georges Anglade (1982, 1990), a urbanização em escala nacional no Haiti não é devedora, tão somente, da industrialização a que suas cidades, especialmente Porto Príncipe, por conta do deliberado processo de importação de produtos e serviços, em particular, dos EUA por uma parte da sua elite econômica. Estamos de acordo com as reflexões desse autor a respeito das consequências do neoliberalismo. No entanto, as 
contradições entre a urbanização e industrialização no Haiti são mais profundas se considerarmos as transformações processuais histórico-sociais da formação socioespacial do país ocorridas em Porto Príncipe, onde cerca de 3/4 dos bairros pobres e periféricos da sua região metropolitana em vias de expansão como indica mapa 6.

Mapa 6 - A expansão urbana da cidade de Porto Príncipe entre de 1982 a 2012

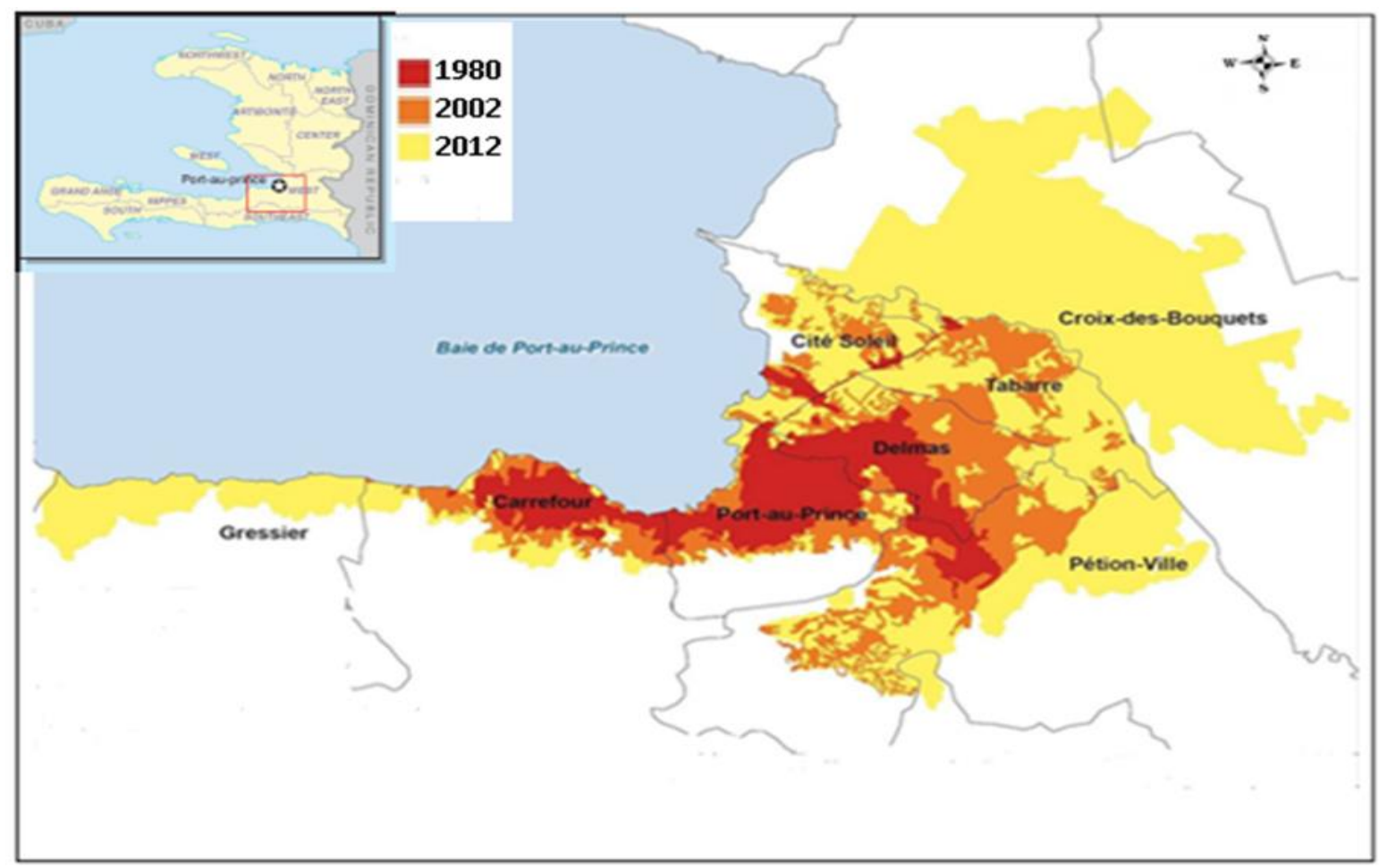

Fonte: CNIGS, 2012. Adaptação: Ismane Desrosiers, 2018

O mapa 6 evidencia a expansão da mancha urbana de Porto Príncipe no período compreendido entre 1980 a 2012, em que é possível observar o crescimento da cidade, principalmente, ao norte, ao nordeste e ao leste. Nesse sentido, pode-se dizer que a metrópole se organiza em torno de três áreas urbanas de características socioeconômicas e geográficas diferentes. De um lado, a área da faixa litorânea localizada em meio às áreas de descarga de esgoto conecta-se diretamente com o centro histórico da metrópole, isto é, os locais onde os habitantes desenvolvem as atividades econômicoformais e informais distribuídos ao longo de uma das principais rodovias. A área à beira-mar nos anos de 1950 e 1960 apresentou-se economicamente como um lugar estratégico para a cidade por meio da indústria do turismo, onde se realizou a Exposição Internacional de 1949, porém, agora, essa área não se mostra tão "atraente" (HOLLY, 1999). Hoje, essa zona costeira pantanosa é ocupada por populações de baixa renda. Ademais, a zona sul é caracterizada geograficamente pelas "ravinas" e por morros 
ocupados pelos moradores de baixa renda; também assinalamos que são áreas de exposição a riscos naturais importantes, como deslizamentos.

Por outro lado, na área central da cidade existem os principais eixos econômicos que são marcados por intensa atividade econômica através de comércio formal e informal. Entretanto, as infraestruturas urbanas básicas não são suficientes em vista da pressão exercida por essas atividades próprias do espaço central metropolitano. Além disso, essa área central da cidade é o local onde existem os principais prédios da administração pública haitiana (Palácio Nacional, Ministérios, Secretarias, Prefeitura Municipal de Porto Príncipe, Banco Central). É uma zona de transição. Por fim, há uma terceira área que é a parte superior da metrópole, que inclui alguns centros urbanos privilegiados (ANGLADE,1982) como Pétion-Ville, bem como muitos bairros considerados abastados que se desenvolvem a partir dessa expansão urbana da cidade.

Desse modo, considerando a expansão da mancha urbana e as características geográficas das áreas dessa metrópole, em termos de distribuição espacial da população na cidade concebemos a expansão urbana de Porto Príncipe como um exemplo do tipo de explosão urbana que Delcourt (2007) qualifica de "Urbanização desenfreada ${ }^{39}$ ", no sentido de que o crescimento populacional urbano engendra formação de favela ou bidonvillle como é conhecido no Haiti, em que as condições de vida são precárias.

Em 2003, a cidade de Porto Príncipe concentrava (e concentra ainda na atualidade) a maior parte dos investimentos públicos e de infraestrutura básicas do país. Dessa maneira, ali se encontrava $35 \%$ das escolas primárias e secundárias, $75 \%$ das escolas superiores e faculdades, mais de $50 \%$ dos hospitais, mais de $2 / 3$ dos bancos, cerca de $80 \%$ da capacidade de consumo de energia elétrica e mais de $70 \%$ das indústrias manufatureiras (IHSI, 2003). Por conseguinte, a infraestrutura criada para apoiar uma população de 100.000 habitantes na primeira metade do século XX está descompassada diante necessidades de uma população de mais de 2.5 milhões de habitantes em 2010; em que aproximadamente 68\% vivem nos chamados bairros desfavorecidos. Portanto, é esta centralização que Georges Anglade (1982) marca como o principal eixo da noção de República de Porto Príncipe.

39 A urbanização desenfreada é um tipo de urbanização constatada em alguns países africanos e asiáticos que torna a cidade quase como sinônima de "favela" A consequência mais óbvia e trágica dessa "urbanização da pobreza" é o crescimento sem precedentes das favelas nos últimos quinze anos (DELCOURT, 2007. p. 49-50). Este autor discorda com todas as teorias clássicas que previam que as cidades representariam um lugar de progresso econômico e humano que levaria de fato a uma melhoria geral nas condições de vida, assumindo uma interação positiva entre urbanização, crescimento e desenvolvimento. 
Com efeito, a ideia de "República de Porto Príncipe" no entendimento do autor é para sinalizar a centralização em Porto Príncipe. Dentro dessa dinâmica, dados do IHSI (2003) mostraram os diferentes fluxos migratórios campo-cidade, que representavam $48,7 \%$ do índice, o que foi seguido logicamente pela migração interurbana que atinge 43\%. E, finalmente, há a migração urbano-campo e inter-campo que absorve, respectivamente, $5,5 \%$ e 2,8\% dos dados coligidos. O Departamento do Oeste, onde se localiza a região metropolitana de Porto Príncipe, é a principal atração migratória. Essa peculiaridade geográfica vista no território nacional absorve $90 \%$ dos migrantes das demais regiões do país. Isso representava cerca de $25 \%$ da população que ali reside (IHSI, 2003). Em outras palavras, os migrantes das áreas rurais e centro-urbanas das cidades de outras regiões do país migram, primordialmente, para a metrópole Porto Príncipe em que a taxa de urbanização está acima da média nacional (66,9\% contra 40,4\%) em 2003. A cidade absorve dois terços (67\%) do crescimento populacional, uma concentração humana muito acentuada. Nesse sentido, o rápido processo de urbanização combinado com o problema de acesso aos serviços básicos e às aparelhagens urbanas explica a dimensão da desigualdade socioespacial no espaço urbano dessa cidade e as condições de vida daquela população. Isso tudo, particularmente, em alguns bairros pobres da cidade de Porto Príncipe em crescimento enquanto o país se urbaniza.

Mapa 7- Fluxo migratório interno entre 1980 a 2003

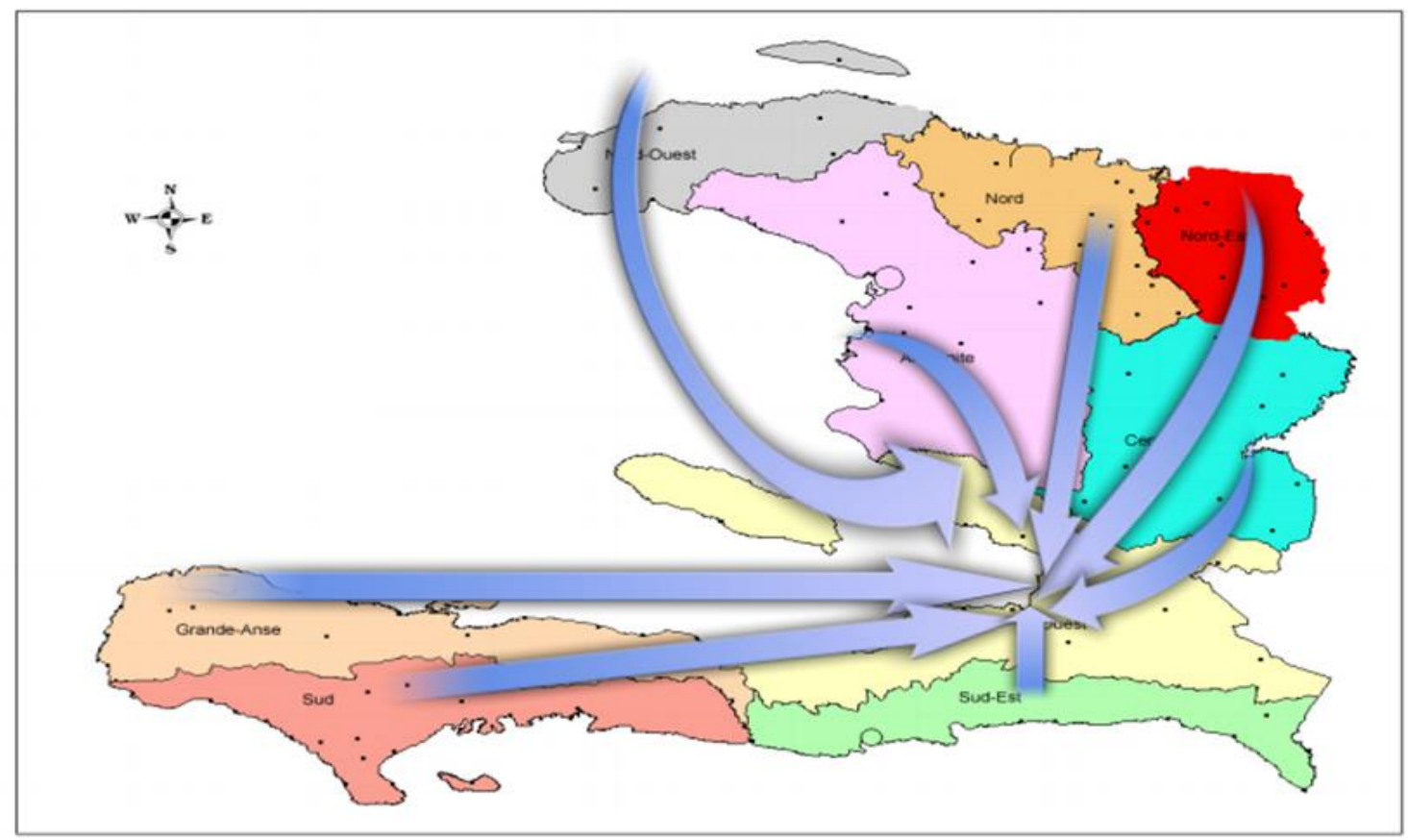

Fonte: IHSI, 2003 
O mapa 7 apresenta as setas de origem e destino que convergem para a região metropolitana de Porto Príncipe entre o período compreendido de 1980 a 2003. Esse fluxo migratório continua na atualidade, pois, segundo dados do IHSI, a metrópole Porto Príncipe conta com uma população de três (3) milhões de habitantes (IHSI, 2018). Assim, como a urbanização do país constitui um dos elementos que transforma a cidade de Porto Príncipe em uma centralidade. Segundo a geógrafa Glória da Anunciação Alves (2018, p. 109), a centralidade ${ }^{40}$ é "um dos atributos entendidos aqui como o local da concentração das atividades econômicas sociais, culturais e políticas". Concordamos com esse argumento da autora, pois a centralidade em Porto Príncipe é o resultado de centralização tanto populacional quanto econômica que conheceu a cidade no início da primeira metade do século XX. Em seguida foi reforçada, na segunda metade do século $\mathrm{XX}$, por meio de um conjunto de medidas políticas tomadas no governo ditatorial de François Duvalier (Papa Doc), entre 1957 a 1971, de fechar dos portos nas cidades provinciais que eram abertos ao comércio externo em favor de Porto Príncipe (CASTOR, 1987). Ademais, nos anos de 1980, o Haiti entra no neoliberalismo abrindo o mercado nacional à concorrência internacional, o que provoca o empobrecimento do campo, questão a ser abordada mais adiante nesta Dissertação.

Dessa maneira, a centralidade, vista enquanto categoria geográfica articula-se com a noção de intencionalidade ${ }^{41}$ que caminha em direção ao sentido da organização do território nacional pelo Estado segundo interesses normatizados (SANTOS, 1996), com ações em relação a seus investimentos intencionais. No decorrer da urbanização do Haiti as cidades provinciais perdem importância em termo de população, comércio, infraestruturas e serviços face à metrópole Porto Príncipe, centro do poder político, econômico e informacional. Todavia, a nosso ver, a decisão do fechamento dos portos nas outras cidades é uma forma "perversa" de pensar o território em termos de planejamento, na medida em que, de um lado, isso não promove a integração nacional numa perspectiva de desenvolvimento socioeconômico do país; e, por outro lado, não se encontra nesse movimento o favorecimento do desenvolvimento regional. Pelo contrário, essas medidas reforçam o desequilíbrio do ponto de vista da distribuição da

40 Utilizamos aqui a categoria de análise geográfica de centralidade apoiando nas reflexões de Alves (2018, pp.109-117) desse fenômeno recorrente no espaço urbano.

41 Consideramos nessa discussão, a noção de intencionalidade a partir da visão de Milton Santos (1996, pp. 89-94). 
população no território nacional, posto que a metrópole Porto Príncipe concentra mais de um terço da população total (IHSI, 2018).

Com efeito, a urbanização do país, a centralização da população, das atividades econômicas reforçam as desigualdades socioespaciais na metrópole Porto Príncipe. Isso em termos de acessos aos serviços básicos como saneamento, habitação digna e transporte e mobilidade urbana de qualidade. Conforme aponta Scarlato (2005) em seu estudo sobre a migração do campo para as cidades:

A presença de uma corrente migratória por si só não explica a condição de vida dos migrantes. Essa será somente a aparência de um fenômeno mais profundo, estruturado em relações socioeconômicas muitas vezes perversas. É o que podemos dizer dos indivíduos que são deslocados do campo para cidades e obrigados a viver em condições de vida culturalmente diferentes das que vivenciam em seu lugar de origem (SCARLATO, 2005, p. 384).

O autor argumenta, ainda, que a grande concentração nas regiões metropolitanas acarreta problemas para as mesmas, tais como crescimento na demanda de emprego, transportes, habitação, saneamento, atendimento de serviços de educação e saúde (Ibidem, 2005, p. 394). Isso é um fato, por exemplo, a região metropolitana de Porto Príncipe, sendo ela o maior polo de atração a que esses movimentos populacionais se orientam. Contudo, a cidade não está preparada para atender as necessidades dos fluxos migratórios. Dito isso, em termos de infraestrutura básica, de saneamento, habitação de qualidade, demanda por emprego, transporte urbano de qualidade. Essas questões são abordadas mais adiante no trabalho. 


\subsection{Transporte e mobilidade urbana em Porto Príncipe}

Com a urbanização do Haiti, o crescimento rápido da população urbana na contemporaneidade transforma a cidade de Porto Príncipe em uma metrópole de três (3) milhões de habitantes (IHSI, 2018) com dimensões absolutamente desiguais incluindo na questão do transporte e da mobilidade urbana. Nessa situação, o Estado não oferece os serviços básicos como, por exemplo, um sistema de transporte adequado à maior parte da população urbana da metrópole. Com efeito, um sistema de transporte atende, de um lado, segurança, por outro lado, eficiência, isso em nível ideal. Por conseguinte, o objetivo final de um sistema de transporte é satisfação adequada das necessidades de mobilidade e de acessibilidade num dado território, isto é, a interação em um conjunto formado em uma rede de diferentes modais de transporte.

Contudo, no que diz respeito a um sistema de transporte no Haiti, especialmente na cidade de Porto Príncipe no final do século XIX, encontramos as tentativas de modernização do sistema de transporte urbano que começou com o transporte ferroviário $^{42}$. A primeira concessão para a construção de um bonde foi concedida em 1876 a um grupo financeiro (Jackson \& Sharp Company) de Nova York, que funda a Companhia de Estrada de Ferro de Porto Príncipe (Compagnie des Chemins de Fer de Port-au-Prince-CCFPP), em 17 de janeiro de 1878. Os estudos de Georges Corvington (1991) apontam que a cidade de Porto Príncipe vivia um primeiro período de transporte que se estruturou por meio de uma rede puxada por cavalos entre 1878 e 1888, e um segundo que começa com locomotivas a vapor em 1897.

A Companhia de Estrada de Ferro de Porto Príncipe (CCFPP) inaugurou um serviço de bonde, cujos trens interurbanos dividiam as ruas de Porto Príncipe com outros meios de transporte urbanos entre 1897 a 1932 (CORVINGTON, 1991). No entanto, o país não consegue construir uma rede ferroviária. Esse idealmente é um dos modais dos transportes mais importantes dentro do âmbito do projeto da modernização da cidade e do país como um todo. Como é observado em vários países da América Latina em desenvolvimento na contemporaneidade, em que a ferrovia foi um dos modais de transportes e ainda mais importantes no transporte de carga e de pessoas. Por exemplo, no Brasil. Desse modo, por que o Haiti não desenvolveu seu sistema de transporte ferroviário no século XIX?

42 Uma estrada de ferro no Haiti Railway Review (Chicago), 15/3/1897, pp. 178-179. Descrição e duas ilustrações do projeto de Tramway de Porto Príncipe. 
Figura 12 - Meio de transporte em Porto Príncipe no final do século XIX e do início do século $\mathrm{XX}$
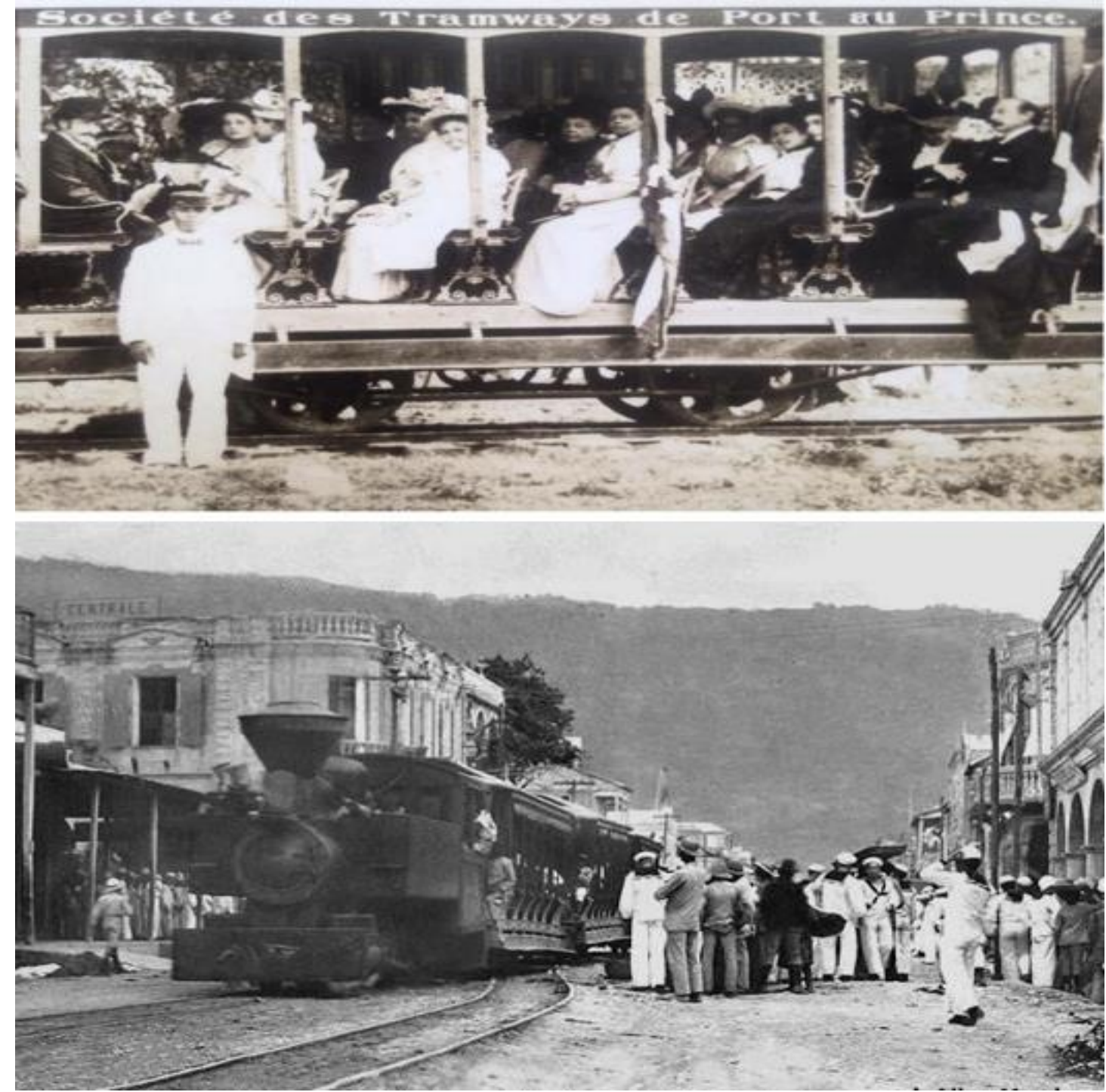

Fonte: Coleções Allen Morrisson. Acesso em: 30 de jul. de 2018.

A figura 12 mostra a circulação dos bondes a vapor no centro da cidade de Porto Príncipe no final do século XIX e no início do século passado. As últimas empresas ferroviárias pararam de operar no Haiti entre 1970 e 1980. Com o desaparecimento da ferrovia local utilizado para transportar cana-de-açúcar para a fábrica de açúcar da Haitian American Sugar Company S.A. (HASCO), o Haiti não possui mais rede ferroviária $^{43}$. Dito em outras palavras, desde a década de 1980 , a rede ferroviária foi abandonada enquanto meios de transporte no Haiti.

43 MICHEL, G. Les Chemins de Fer de l'Ile d'Hä̈ti. Presses de l'Imprimerie le Natal, Deuxième édition revue et corrigée. Port-au-Prince. 1989. 160 p 
Mapa 8 - Mapa metropolitano do transporte ferroviário em 1930

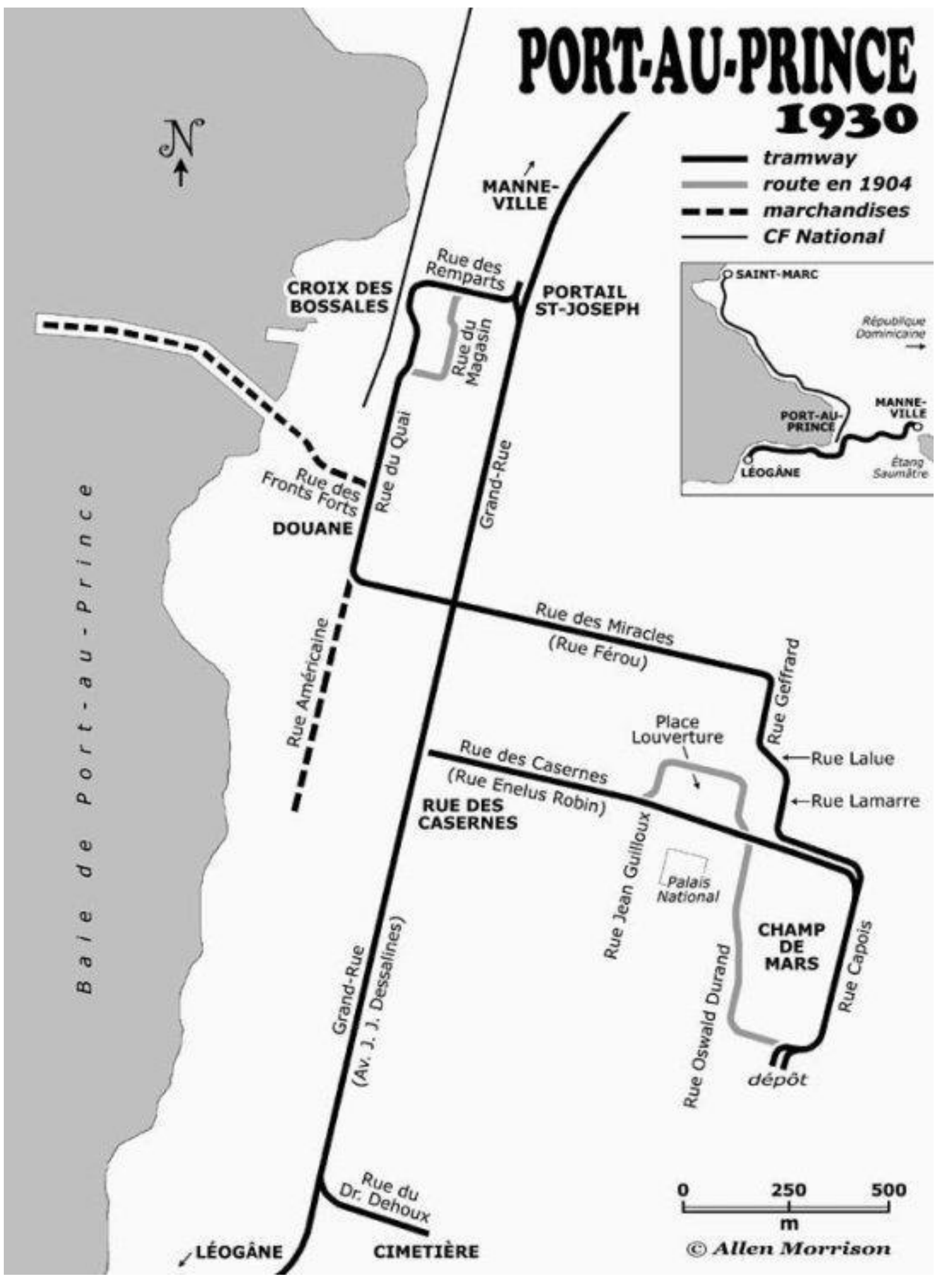

Fonte: http://www.caraibeexpress.com/la-une/article/les-tramways-de-port-au-prince Acesso em: 30 de jul. de 2018.

O mapa 8 apresenta a rede ferroviária do transporte metropolitano na cidade de Porto Príncipe entre 1897 e 1932. Em 18 de abril de 1897 a Companhia de Estrada de 
Ferro de Porto Príncipe inaugurou a primeira linha do seu bonde a vapor, do Portail Saint Joseph pelas ruas Quai e Miracles até o terminal de Champ de Mars, e depois a rua Casernes. A segunda linha compreende da Av. J. J. Dessalines, do Portail de Saint Joseph até o terminal do Cemitério de Porto Príncipe. Outra Companhia de estrada de ferro foi a da planície do Cul-de-Sac que opera as novas linhas rurais, de Porto Príncipe a Léogâne na baía em uma extensão de 36 km a oeste da cidade. Mapas topográficos da década de 1950 mostram uma fusão das linhas rurais da antiga companhia de estrada de ferro de Porto Príncipe com a rede da Companhia Nacional Ferroviária do Haiti (CORVINGTON, 1991). Com a chegada de automóvel no Haiti, apesar de que país não desenvolver a indústria automobilística, de alguma forma, esta substitui enquanto meio de transporte e que marca o fim das tentativas de consolidar uma rede ferrovia na cidade e no Haiti como o todo.

Dessa maneira, a questão do transporte e da mobilidade urbana na metrópole Porto Príncipe na atualidade é problemática no contexto de urbanização do país e da centralização em Porto Príncipe. Nota-se a dificuldade da circulação de pessoas, mercadorias e de veículos na metrópole. No entanto, a legislação haitiana relativa ao planejamento urbano e ao trânsito tornar o município de Porto Príncipe a única entidade responsável por planejar o transporte. Com efeito, salientamos que as ações do Estado no campo de planejamento urbano foram abandonadas ao longo dos anos de 1970, resultando em uma situação urbana catastrófica. Contudo desde 1937, a lei sobre planejamento urbano estabelece "regras especiais para habitação e urbanismo e paisagístico" no processo de desenvolvimento das cidades haitianas. Nesse mesmo movimento, foi publicado o Decreto de 1982, com especificidades relativas aos assentamentos urbanos, abordando, também, o aspecto da infraestrutura rodoviária no transporte urbano (HAITI, 1980).

Nesse sentido, com a urbanização do Haiti e centralização em Porto Príncipe, a demanda pelo transporte e pela mobilidade urbana cresce, apesar de que a cada ano há o aumento do número de veículos em circulação, porém, sem criar novas estradas na capital haitiana para atender a demanda do serviço do transporte público coletivo. Com efeito, o transporte público na região metropolitana é estruturado por diferentes tipos de veículos: ônibus, miniônibus e "tap-tap" como indica a figura 13. Em alguns circuitos existem veículos específicos, e em outros encontramos todos os tipos de veículos disponíveis. No entanto, todas essas categorias não são suficientes para atender a demanda crescente dos passageiros no que tange a um serviço adequado e seguro. 
Figura 13 - Os meios de transporte coletivo interurbano na RMPP em 2017

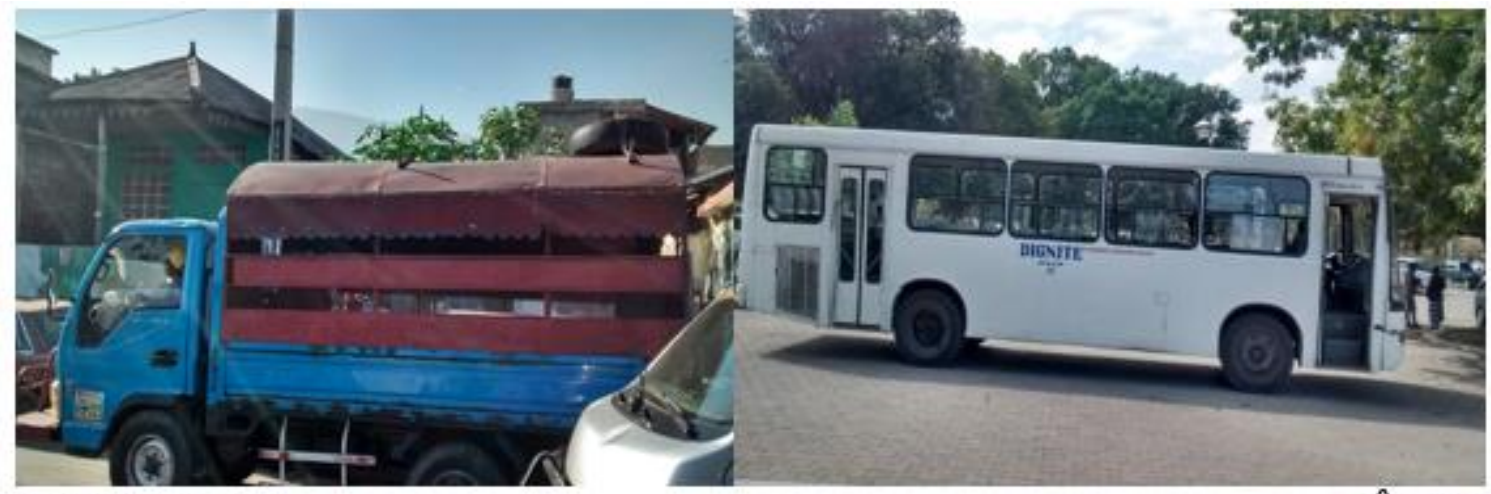

Camião ônibus

Ônibus

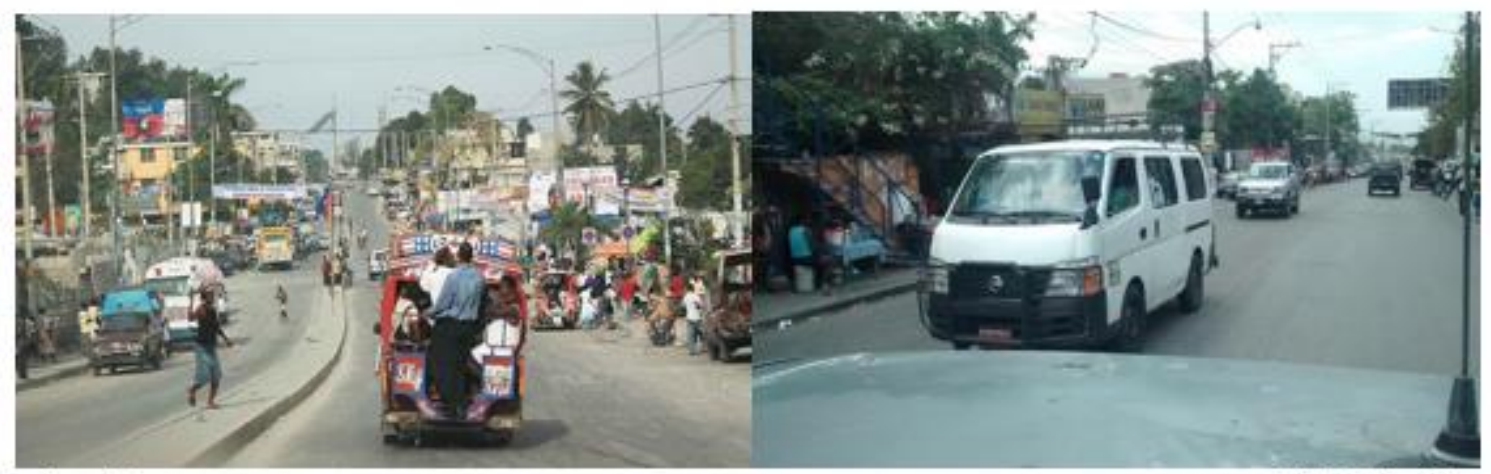

Tap Tap

Mini ônibus

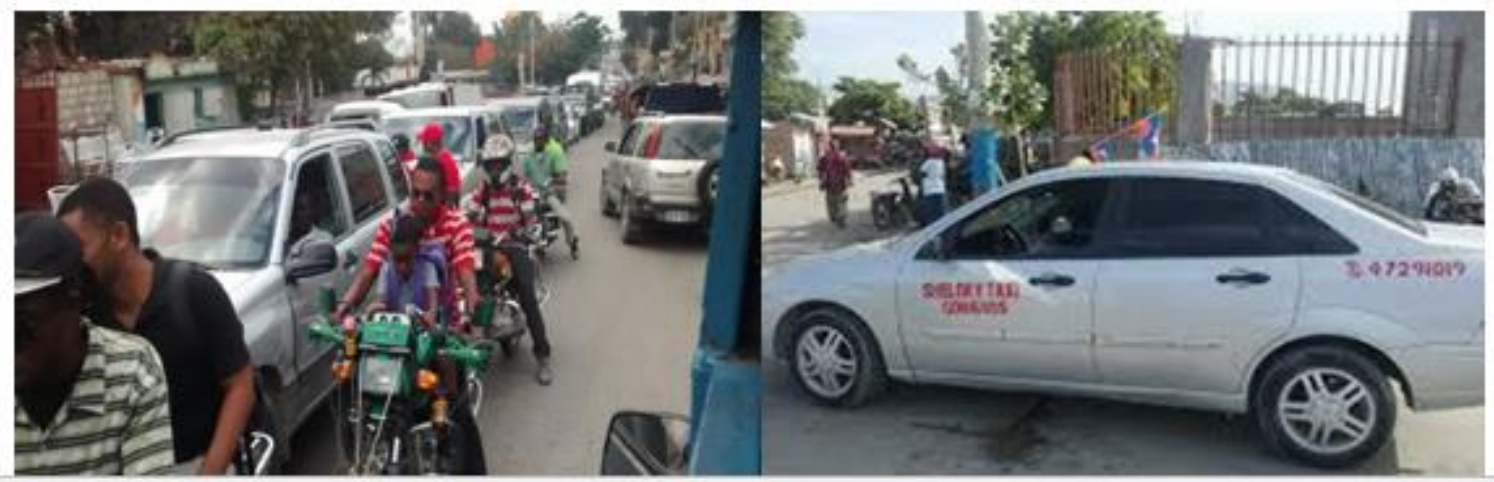

Fonte: Trabalho de campo, 2017.

A figura 13 mostra os diferentes tipos de veículos no transporte público interurbano na região metropolitana de Porto Príncipe. É possível observar que não é um sistema de transporte urbano organizado, no sentido que na cidade esse serviço é fornecido, principalmente, por dois setores. Por um lado, há o Estado que possui duas empresas Dignité e Service Plus. A empresa Service Plus operava em 2005, com uma frota de 115 ônibus fabricados nos Estados Unidos; são ônibus de média e de grande capacidade, com no máximo 5.750 assentos. Essa foi a totalidade dessa frota de 
transporte, responsável, principalmente, por atender alunos em idade escolar. Os mesmos ônibus, doravante, são usados também para o transporte de passageiros na região metropolitana de Porto Príncipe (IHSI, MEF, 2007). Por outro lado, há o setor privado informal atuando no transporte metropolitano. Nesse setor, qualquer pessoa que possui uma van, um mini ônibus ou outro tipo de veículo motorizado pode usá-lo no transporte dos passageiros na cidade. O transporte público na região metropolitana de Porto Príncipe sofre com uma série de problemas organizacionais, na medida em que não há um controle organizacional com uma política pública de transporte desenvolvida pelo Estado. Os veículos que fazem o transporte público na região metropolitana de Porto Príncipe não possuem terminais estruturados e são poucos os pontos de paradas. Portanto, os motoristas são forçados a estacionar na rua para pegar os passageiros, pois eles não se orientam por paradas programáticas. ${ }^{44}$ A distância entre os pontos de parada não é delimitada. Além disso, salientamos que os veículos não possuem horários programáticos.

O Tap-Tap é o modelo de veículo de transporte público mais utilizado na região metropolitana de Porto Príncipe. Esse veículo, de capacidade muito pequena, faz parte da história do transporte público da cidade de Porto Príncipe. Estimado em 5\% da frota de veículos de transporte metropolitano, em 1990; portanto, responsável por vários circuitos existentes na metrópole. Ele transporta aproximadamente 16 pessoas em condições precárias e representava, em 2005, 56\% dos veículos do setor privado informal segundo dados da enquete sobre os transportes de 2004 a 2005 do MEF e do IHSI (2007). De um total de 21.387 veículos estimados na região metropolitana de Porto Príncipe, em 2005, houve 13.943 Tap Tap, 7.444 ônibus e 1.199 táxis (IHSI, MEF, 2007) ${ }^{45}$. Estatísticas recentes sobre o número de veículos relacionados ao transporte público em Porto Príncipe não estão disponíveis até o momento da escrita desta Dissertação de Mestrado. No entanto, falamos de uma metrópole de três (3) milhões de habitantes em 2018 (IHSI, 2018), onde o transporte urbano deve idealmente integrar trem, metrô e ônibus oferecendo um serviço seguro e eficaz em termos de

$44 \mathrm{O}$ tempo gasto por ônibus é estimado em dobro e triplo o que devemos gastar na medida em que a distância entre os diferentes municípios da Região Metropolitana é em grande parte inadequada ao tempo de transporte. A distância entre o cruzamento e Porto Príncipe é de $8 \mathrm{~km}$, a de Delmas 73 e o centro da cidade a $3 \mathrm{~km}$ e Porto Príncipe e Pétion-Ville a $6 \mathrm{~km}$. Para sair de uma cidade para ir para outro tempo gasto de ônibus é estimado em uma média de uma hora. Mais informações disponíveis em: www.tiptopglobe.com Acesso em: 24 de jul. de 2018.

45 Enquete transporte 2004-2005: Resultados definitivos, do Ministério da Economia e das Finanças (MEF) e Instituto Haitiano de Estatística e de Informática (IHSI). Port-au-Prince, 2007. 
mobilidade e de acessibilidade população urbana, sobretudo no que diz respeito às pessoas com mobilidade reduzidas que têm dificuldades ${ }^{46}$. O deslocamento na cidade nessas condições descritas é um problema a ser considerado por meio de uma política pública do transporte urbano, pois ele aumentou na cidade após o terremoto de 2010, onde, por exemplo, muitos cidadãos tornaram-se deficientes físicos a partir dos seus membros inferiores. Ou seja, esses sujeitos passaram a depender do uso de muletas e de cadeira de rodas. Isso agravou ainda mais o problema da mobilidade e de acessibilidade dessa parte da população urbana de Porto Príncipe.

Atualmente, pouco se sabe sobre o número de ônibus e outros tipos de veículos atuando no transporte público junto à população urbana da região metropolitana de Porto Príncipe. Contudo, uma considerável porcentagem de viagens diárias é geralmente feita sem o uso de veículos, sobretudo entre os moradores dos bairros pobres; e isso devido à baixa renda per capita desses moradores. De um lado, há a proximidade geográfica das cidades da região metropolitana, por outro lado, há a questão social relacionada ao desemprego dessas pessoas. Segundo dados obtidos da enquete sobre o transporte 2004 a 2005 (IHSI, MEF, 2007), o transporte urbano é feito a partir de duas variáveis que são as seguintes: o custo da viagem e a quantidade de passageiros reduzida transportados. Nesse sentido, salientamos que desigualdades se manifestam, também, do ponto de vista da mobilidade e da acessibilidade na região metropolitana de Porto Príncipe, na medida em que de acordo com dados do MTPTC em 1996, apenas $17,20 \%$ da frota de veículos na metrópole se dedicava ao transporte público em comparação com 70,15\% de veículos particulares (MTPTC, 1997).

46 A maioria das estradas na região metropolitana não possui sinais de trânsito. Aqueles que funcionam não trabalham o tempo todo nos poucos cruzamentos das ruas onde eles existem. A ausência de sinais ou sua disfunção paralisa a circulação consideravelmente. Todos os motoristas querem passar ao mesmo tempo. Além disso, esta situação é realmente difícil para os pedestres que atravessam as ruas. Calçadas são ocupadas por comerciantes. Eles não são mais reservados para pedestres, eles são forçados a andar pelas ruas e cruzar em qualquer lugar. Isso representa um perigo real para pedestres e vendedores ambulantes em caso de acidente. Por exemplo, ocorreu em 13 de março de 2013 um acidente. Informações disponíveis em: http://hpnhaiti.com/site/index.php/societe/8945-haiti-accident-aquinplusieurs-blesses-graves-transportes-a-port-au-prince Acesso em: 25 de agosto de 2018. 


\section{Mapa 9 - Os grandes eixos da circulação na RMPP}

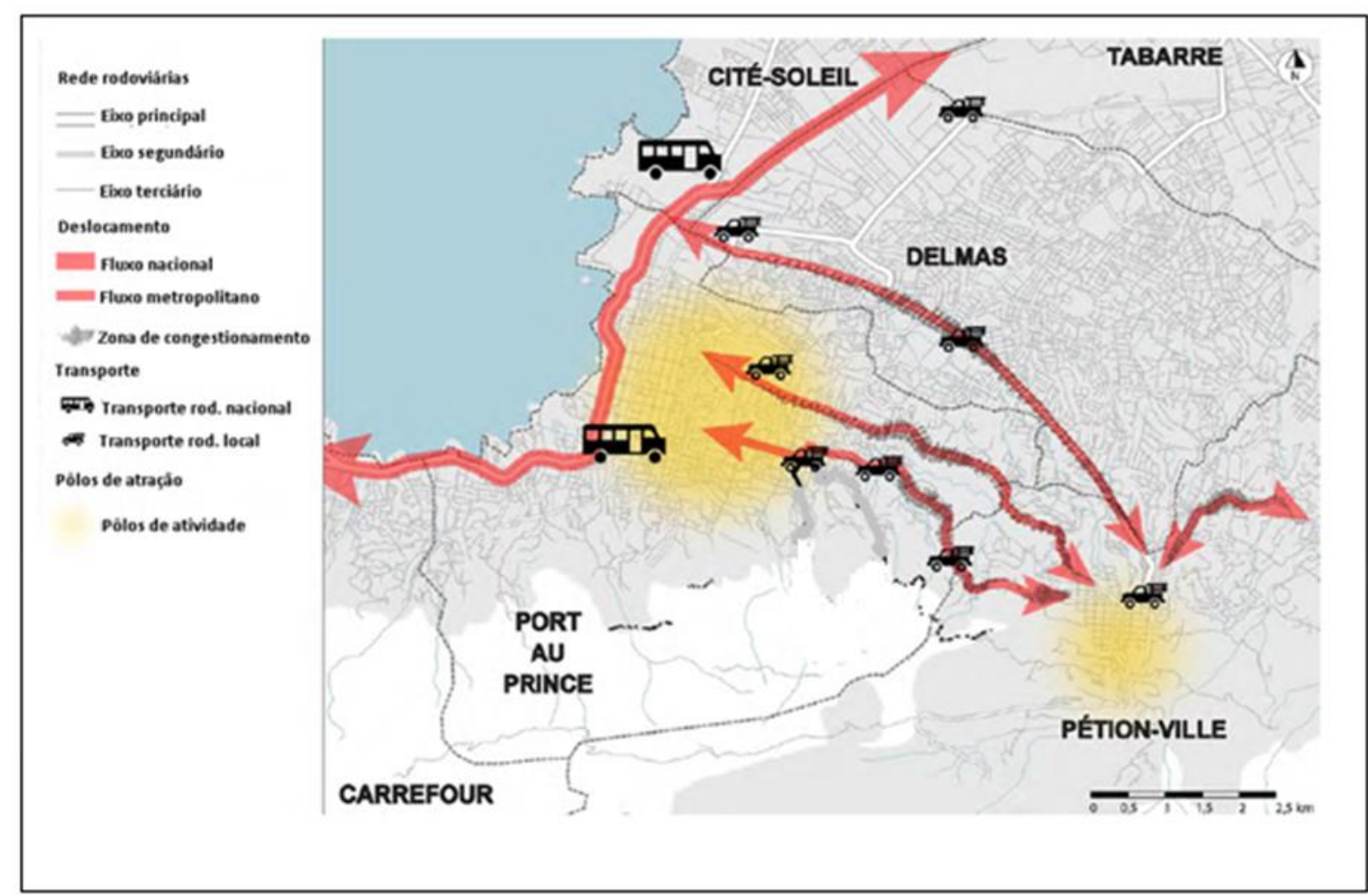

Fonte: GOAL Haiti, 2015. Adaptação: Ismane Desrosiers, 2018.

O mapa 9 apresenta a rede viária da região metropolitana de Porto Príncipe. Ela enfrenta vários problemas relacionados ao gerenciamento de tráfego, onde todas as vias da região metropolitana passam, geralmente, pelo centro histórico. A extensão atual da rede rodoviária metropolitana é insuficiente, sendo, em muitos sentidos, de má qualidade diante do volume de veículos que circulam na cidade. Dependendo das funções executadas, a infraestrutura viária metropolitana divide-se em três categorias. As rodovias que fazem ligação com outras entidades geográficas do país; as estradas secundárias; e, por fim, as ruas dos bairros. Entretanto, há ausência de um conjunto de normas de circulação como as sinalizações verticais, horizontais e a interligação dos modais de transporte.

Nesse sentido, a carência de normas básicas do planejamento urbano e do transporte metropolitano em Porto Príncipe reforça a espontaneidade dos bairros irregulares de forte densidade demográfica. Dentro dessa dinâmica urbana, o circuito, por exemplo, que vai do município de Pétion-Ville para o do Carrefour, passando pelo centro histórico da cidade, enfrente problema do engarrafamento, sobretudo nos horários de pico. Além disso, as ruas de bairros são restritas e dificultam, assim, os trajetos dos motoristas. Desta forma, muitas vezes é impossível que dois motoristas 
circulam em direção oposta entre essas ruas. À vista disso, o acordo ou o desacordo informal entre os motoristas substitui os padrões de circulação no espaço urbano, ou seja, os sinais de trânsito. Portanto, a inexistência desses pré-requisitos básicos na organização do transporte afeta a mobilidade dos fluxos de pessoas e de mercadorias na metrópole.

Com efeito, um sistema de transporte público urbano organiza-se, em tese, de modo que o tráfego que ela gera não impeça a circulação das pessoas e das mercadorias. Nesse sentido, faz-se necessário, a modificação, de algum modo, da estrutura urbana, associando-a, tanto quanto possível, aos complexos residenciais próprios da rede metropolitana de transportes urbanos. Tudo isso, acreditamos, visando atender ao maior número possível de pessoas. Essa iniciativa será benéfica, em tese, para toda a comunidade metropolitana. A organização racional dos traçados das ruas, por exemplo, independente do padrão de estrada adotado, é um dos passos básicos para que as autoridades públicas possam facilitem a mobilidade e a acessibilidade pelas vias da cidade.

\section{Gráfico 9 - Intensidade do transporte na região metropolitano}

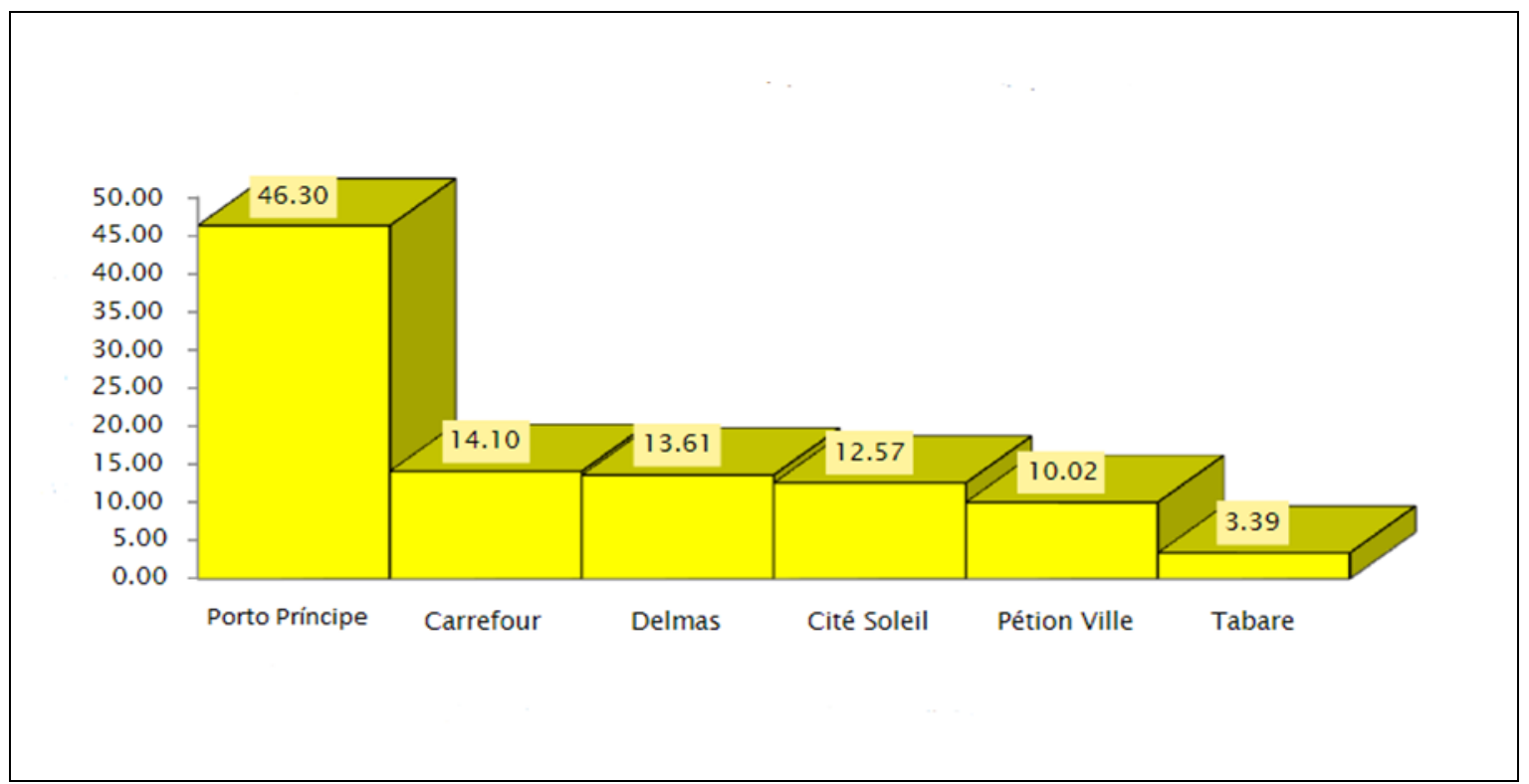

Fonte: BID, 2011. Adaptação: Ismane Desrosiers, 2018.

O gráfico 9 apresenta a intensidade do transporte metropolitano diário. Nele percebemos a grande movimentação na cidade de Porto Príncipe em termos de porcentagem. Isso é explicado pelo impacto da cidade de Porto Príncipe em relação às outras cidades metropolitanas no que se refere ao sistema de transporte e, também, junto à desordem urbana que a metrópole haitiana promove. Portanto, no que concerne o transporte intermunicipal das cinco cidades periféricas possuem ligações direto com o 
centro da cidade de Porto Príncipe (HOLLY, 1999), em que há más condições junto às vias urbanas; com veículos lotados que às vezes não são apropriados para o transporte dos passageiros. Ademais, o crescimento da frota de veículos no transporte público metropolitano apresenta um grande desafio para a mobilidade e a acessibilidade na cidade sem levar em conta as normas de trânsito (IHSI, 2007).

Enfim, como vimos o meio de transporte mais usado em Porto Príncipe é o Tap Tap. Desta forma, faz-se necessário a modernização do sistema de transporte metropolitano. Parece interessante substituir esses veículos pequenos por ônibus de maior capacidade de transporte de passageiro. Além disso, há a demanda de regras e normas mínimas de segurança que garantam um seguro código de ética de tráfego para os passageiros e transeuntes. Para uma metrópole de três (3) milhões de habitantes em 2018 (IHSI, 2018), cremos que o setor de transporte deve passar por investimentos ou inovações. Por que no projeto de requalificação urbana, "Cité Administrativa" não aborda a questão do transporte e da mobilidade urbana? Portanto, entendemos que o sistema de transporte público existente na região de Porto Príncipe não atende satisfatoriamente a crescente demanda por um transporte público minimamente eficiente. Ademais, mesmo que haja um aumento na frota de veículos de transporte urbano, a infraestrutura atual não é capaz de acompanhar esse movimento. Parece ser viável pensar esses problemas de ordem pública ou dois fatores conjugados em termos de uma parceria público-privada.

Faz-se necessário uma resposta para essa complexa situação do transporte e da mobilidade urbana em Porto Príncipe, pois ocorre não apenas a ausência de uma política pública de transporte, mas, também, a ausência e/ou o desrespeito dos padrões de planejamento urbano. Por conseguinte, a melhoria das condições de transporte e da mobilidade urbana na região metropolitana exige o desenvolvimento de um plano intermodalidade de transporte. Portanto, o papel do Estado, nesse âmbito, requer sérias reformas. Isso face à sua responsabilidade enquanto agente regulador do espaço que é a de projetar e de planejar a estrutura urbana; de implementar e construir infraestrutura urbana a fim de diminuir as desigualdades socioespaciais junto ao desenvolvimento da cidade. Ou seja, ao Estado está atribuída a capacidade de garantir o direito à mobilidade e à acessibilidade urbana por meio de um sistema de transporte público de qualidade. Dito isso, do ponto de vista socioeconômico para satisfazer, sobretudo, às populações pobres da cidade que não possuem veículos particulares e, de um modo mais geral, para todas as pessoas que não usufruem do privilégio oferecido por um veículo individual. 


\subsection{Desigualdades socioespaciais na cidade a partir da questão habitacional}

Como observamos, a urbanização do Haiti contribui para a transformação profunda da organização socioespacial da cidade de Porto Príncipe. Essa transformação ocorre devido à centralização das atividades econômicas na cidade sem aplicação ideal de um plano de desenvolvimento urbano da metrópole. No entanto, veremos mais adiante, um conjunto de planos, projetos e programas que foram desenvolvidos no campo do planejamento urbano no Haiti. Mas, estes não surtiram efeito por causa da forma e o conteúdo da atual metrópole de três (3) milhões de habitantes (IHSI, 2018). Com efeito, desde 1950 as políticas de planejamento urbano e regional foram introduzidas no Haiti com a criação do Escritório Nacional de Planejamento (BNP) por meio do Ministério das Obras Públicas, Transportes e Comunicações (MTPTC).

No seu livro intitulado Por uma geografia nova (1978), Milton Santos considera a categoria espaço como central. Para o autor, o espaço é compreendido como um conjunto de formas representativas de relações sociais do passado e do presente e por uma estrutura representada por relações que estão acontecendo e manifestam-se através de processos e funções. "Eis a razão pela qual a evolução espacial não se apresenta de igual forma em todos os lugares (SANTOS, p. 122)". Ele disse ainda que:

O espaço por suas características e por seu funcionamento, pelo que ele oferece a alguns e recusa a outros, pela seleção de localização feita entre as atividades e entre os homens, é o resultado de uma práxis coletiva que reproduz as relações sociais, (...) o espaço evolui pelo movimento da sociedade total (Ibidem, 1978, p. 171).

Conforme aponta o mesmo autor em Espaço e Sociedade (1979), a forma aparece como condição da história. Ou seja, as formas permanecem como herança das divisões do trabalho efetivadas no passado e as formas novas surgem como exigência funcional da divisão do trabalho atual. As formas que não têm as mesmas significações ao longo da história do país, da região e do lugar representam a acumulação de tempo e sua compreensão depende do que foram as divisões do trabalho:

Seria impossível pensar em evolução do espaço se o tempo não tivesse existência no tempo histórico, (...) a sociedade evolui no tempo e no espaço. O espaço é o resultado dessa associação que se desfaz e se renova continuamente, entre uma sociedade em movimento permanente e uma paisagem em evolução permanente. (...) somente a partir da unidade do espaço e do tempo, das formas e do seu conteúdo, é que se podem interpretar as diversas modalidades de organização espacial (SANTOS, 1979, pp. 42-43).

Com efeito, em termos de organização espacial, de 1974 a 2004, vários planos, projetos e programas foram produzidos para orientação do desenvolvimento urbano da 
cidade, por exemplo, o Plano de Desenvolvimento de Porto Príncipe e sua região metropolitana (PDPPRM), preparado pelo Conselho Nacional de Desenvolvimento e Planejamento (CONADEP) ${ }^{47}$ junto com o Ministério das Obras Públicas, Transporte e Transporte (MTPTC) e as Organizações das Nações Unidas (ONU). O objetivo desse estudo foi identificar várias opções disponíveis para orientar o desenvolvimento futuro da região metropolitana de Porto Príncipe entre 1976 a 1986, tendo uma visão geral para os anos de 2000 (MTPTC, 1974). Posteriormente, o plano Diretor da cidade de Porto Príncipe (PNUD, 1988); o Plano Nacional de Habitat e Habitação (UNDP, 1996); o Projeto de Apoio Municipal e Apoio ao Planejamento Espacial (PNUD, 1996); Plano Diretor de Saneamento da Região Metropolitana de Porto Príncipe (PDSRMPP).

Além disso, houve o Plano de Drenagem da Região Metropolitana de Porto Príncipe (PDRMPP), o Plano Diretor do Fundo do Mar da Cidade de Porto Príncipe (PDFMCPP) por meio do Escritório de Infraestruturas e Planejamento Urbano da Presidência da República do Haiti, através da comissão para a comemoração de $250^{\text {a }}$ da fundação da cidade de Porto Príncipe (1999). O Plano de Planejamento Urbano da região metropolitana de Porto Príncipe desenvolve por MTPTC em 2000, como parte dos programas de iniciativas urbanas para Porto Príncipe. E o mais recente plano é o projeto de requalificação urbana denominada Cité Administrative que está desde 2012, em implementação como já discutimos no primeiro capítulo do trabalho.

Esses planos, projetos e programas urbanos, principalmente, a respeito da cidade de Porto Príncipe não foram feitos idealmente para controlar o desenvolvimento da cidade e diminuir as desigualdades socioespaciais no espaço urbano da metrópole. Além do mais, fora do projeto de requalificação urbana após o terremoto de 2010, os planos e projetos anteriores não foram colocados em práticas. Esse projeto Cité Administrativa, como já foi visto, pretende valorizar somente as áreas administrativas enquanto a questão habitacional no contexto de reconstrução da cidade deixa de lado. No entanto, as desigualdades socioespaciais vistas por meio da questão habitacional são evidenciadas através da distribuição da população em bairros de poder aquisitivo alto e baixo na cidade já desde anos 1980. Tudo isso é demonstrado nos estudos de Henry Godard (1985) sobre a cidade de Porto Príncipe.

47 Disponível em http://data.bnf.fr/1213conseil_national_de_developpement_et_de_planification_haiti/ Acesso em: 31 de jul. de 2018. 


\section{Mapa 10 - A distribuição da população na RMPP em 1985}

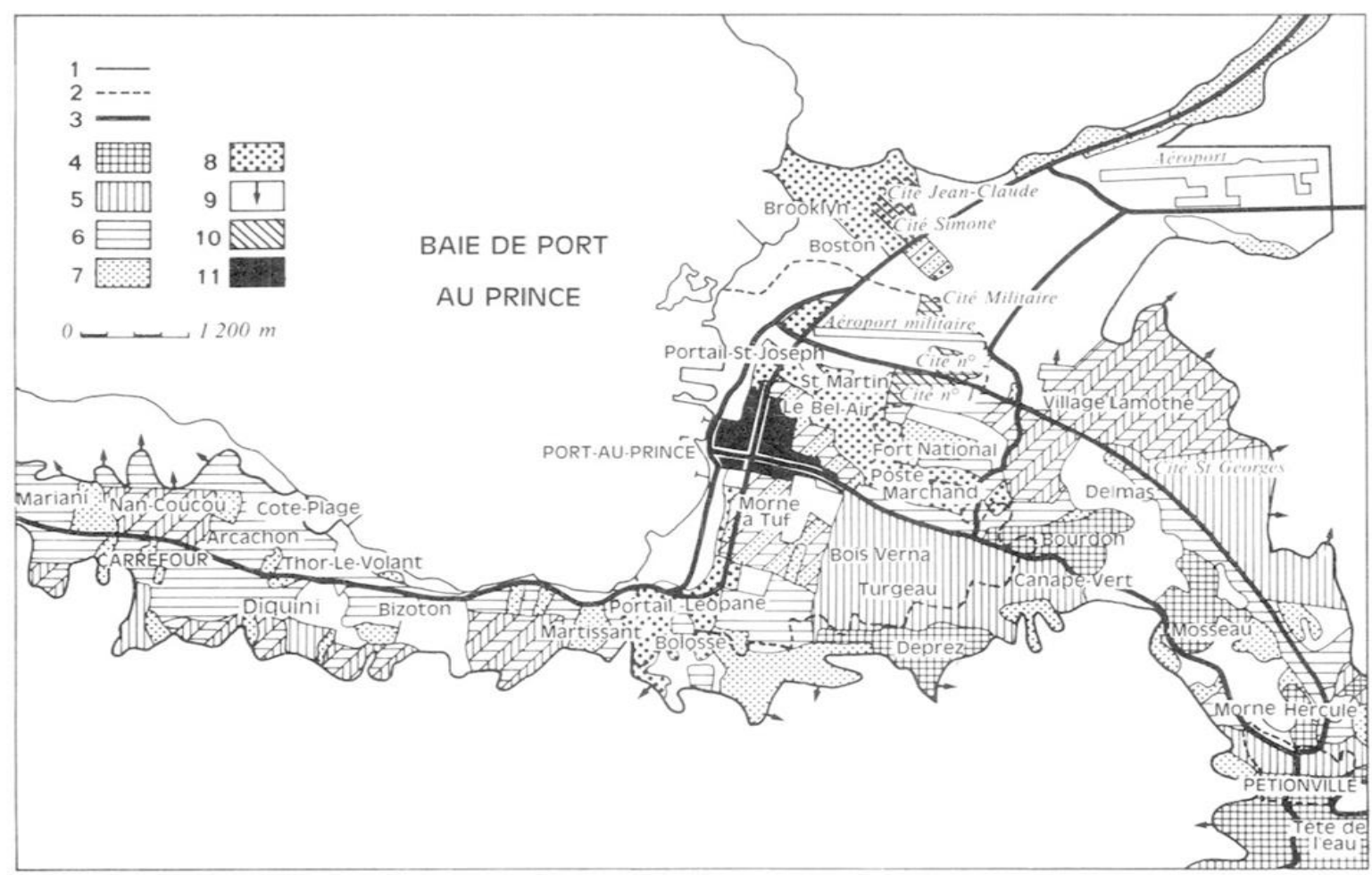

Fonte: Henry Godard (1985, p. 20). 1.- Zona urbanizada em 1982; 2.- Zona urbanizada em 1952. 3.Estrada principal. 4.- Habitação de classe média alta. 5.- Habitação de classe média. 6.- Habitação de classe média baixa. 7.- Habitação precária. 8.- Habitação de extremamente precariedade. 9.- Extensão de habitat. 10.-Cidade planejada. 11.- Centro.

O mapa 10 mostra a distribuição da população urbana em bairros na cidade de Porto Príncipe. Nele, observamos que desde os anos de 1980, as desigualdades socioespaciais já eram evidentes através da distribuição da população dos bairros de habitação de classe média alta até habitação de extrema precariedade. Nesse sentido, a questão habitacional sempre foi preocupante, sobretudo, nos bairros pobres. Em outras palavras, o problema habitacional é um dos desafios enfrentados pelos moradores da região metropolitana de Porto Príncipe, mesmo antes do terremoto de 2010. Com efeito, para compreender as condições de habitação dos moradores da região metropolitana de Porto Príncipe, devemos partir das desigualdades socioeconômicas e ambientais dos assentamentos humanos na cidade. É evidente que uma habitação decente é um dos direitos fundamentais, bem como o direito à alimentação, saúde, educação. A ideia de habitação decente foi desenvolvida gradualmente ao longo do século XX em países industrializados. Nos Estados Unidos, França, Canadá, por exemplo, este direito é integrado na constituição e previsto através de políticas públicas. Além disso, 
Por quarenta anos, as Nações Unidas estiveram preocupadas de fato com o desenvolvimento das cidades e o acesso de todos a uma habitação adequada. Com a Declaração de Vancouver em 1976 e a entrada em vigor do Pacto Internacional sobre os Direitos Econômicos, Sociais e Culturais e a Declaração de Istambul sobre os Estabelecimentos Humanos e o programa para o Habitat, em 1996, os países signatários comprometem-se a garantir a todos habitação adequada e fazer assentamentos humanos mais seguros, mais saudáveis, mais habitáveis, equitativos, sustentáveis e produtivos (ONU, 1996, p. 1)

No mesmo objetivo, a Sessão Especial da Assembleia Geral da ONU, realizada em Nova York de 6 a 8 de junho de 2001, concentrou-se na revisão geral e na avaliação dos progressos realizados na implementação dos resultados da cúpula sobre o Habitat em 1996. Após a sessão, a Assembleia Geral adotou a "Declaração sobre Cidades e Outros Assentamentos Humanos no Novo Milênio ${ }^{48 "}$. Nesse sentido, as propostas de novas medidas para alcançar as metas de moradia adequada para todos e o desenvolvimento sustentável de assentamentos humanos foram feitas (ONU, 2001). Conforme aponta a Organização das Nações Unidas, através do Programa das Nações Unidas para os Assentamentos Humanos (ONUHABITAT), a problemática habitacional nas cidades está cada vez mais se tornando preocupante na medida em que hoje, mais da metade da população mundial vive na cidade (ONU, 2014) ${ }^{49}$.

Desse modo, no caso do Haiti, a situação não é diferente devido, de um lado, à urbanização que conhece o país nas últimas três décadas e, de outro, à destruição da capital do país pelo terremoto de 2010, quando a habitação foi severamente atingida, sobretudo, nos bairros desfavorecidos na estrutura urbana da cidade. Portanto, com isso, o déficit habitacional agravou de 2010 até hoje. Contudo, salienta-se que, o artigo 22 da Constituição haitiana de 1987 estipula que o "Estado reconhece o direito de todos os cidadãos à moradia decente”. Na mesma ordem de ideia, o artigo 25 da Declaração Universal dos Direitos Humanos, que a República do Haiti é um dos quarenta e três (43) primeiros signatários, se reconhece que "toda pessoa tem direito a um padrão de vida adequado para assegurar a sua saúde, seu bem-estar e de sua família, inclusive alimentação, vestuário, habitação, [...] assistência médica e serviços sociais necessários" (ONU, 1948).

48 Disponível em: http://www.participa.br/habitat/declaracao-milenio-istambul-5-ingl-s-.pdf Acesso em: 15 de ago. de 2018.

49 Fonte https://gauchazh.clicrbs.com.br/educacao-e-emprego/noticia/2014/07/Mais-de-metade-dapopulacao-mundial-ja-vive-em-areas-urbanas-diz-ONU-4547970.html . Acesso em: 10 de nov. de 2018. 
De acordo com Henry Godard (1985), a partir dos anos de 1960, a classe de nível de renda alta de Porto Príncipe deixou o centro para se estabelecer na cidade de Pétion-Ville: $400 \mathrm{~m}$, de uma temperatura média anual de $24,7^{\circ} \mathrm{C}$. Os antigos bairros de classe média de renda alta, cuja população original foi gradualmente substituída por moradores de baixa renda. $\mathrm{O}$ autor disse que a infraestrutura urbana, os planos e projetos habitacionais não foram desenvolvidos no mesmo ritmo da urbanização, a qualidade de vida urbana no centro deteriorou-se consideravelmente (GODARD, 1985). Isso pode ser evidenciado por densidade demográfica, a pressão sobre serviços básicos e infraestruturais já limitados na cidade.

Lavalin (1988), no seu estudo, fez uma tipologia ${ }^{50}$ de zonas de habitat na região metropolitana de Porto Príncipe em que identificou as seguintes zonas de habitat: primeiro as áreas densamente habitadas de uma forma espontânea, com uma densidade populacional de $1800 \mathrm{ha} / \mathrm{km}^{2}$, geralmente precárias, localizadas nas terras baixas, que são classificadas como habitação de muito baixa qualidade. Ali, a habitação é mais frequentemente um quarto, em que pode viver uma família inteira. Essas áreas contêm claramente a população de renda bastante baixa. Mostra-se que a área onde se localiza o habitat com uma densidade demográfica de 550 a 700 ha/ $/ \mathrm{km}^{2}$ é de baixa renda nos morros com poucos equipamentos urbanos. Ele aponta as áreas de subdivisão com densidade demográfica 500 hab./ $\mathrm{km}^{2}$, de baixas condições de vida e semelhantes à categoria anterior. Ou seja, essas áreas de subdivisões apresentam densidade demográfica com $300 \mathrm{ha} / \mathrm{km}^{2}$, de padrão médio, atendidas por todas as redes de serviços urbanos. As áreas de subdivisão com densidade de demográfica de 50 a 100 ha/ $/ \mathrm{km}^{2}$ são bem equipadas em termos de infraestruturas e de equipamentos urbanos.

Desse modo, a partir da análise da tipologia habitacional na cidade feita por Levalin (1988), pode-se dizer que as desigualdades na metrópole não são apenas sociais, elas são, também, espaciais diante da distribuição e dos acessos aos equipamentos urbanos. Isso pode ser constatado pelo acesso aos centros de saúde, escolas, praças públicas, áreas verdes, lazeres, água, saneamento básico, tratamento de esgoto, via de circulação pavimentada. Ademais, as desigualdades são marcadas por meio da localização das habitações, em função do tipo de relevo. Entretanto, as desigualdades socioespaciais são mais visíveis, isto é, qualquer observador atento às múltiplas

50 Plano Diretor de Porto Príncipe de Lavalin (1988), da região metropolitana de Porto Príncipe. Estudo realizado com apoio do Ministério das Obras Públicas, Transportes e Comunicações (MTPTC) e do Programa das Nações Unidas para o Desenvolvimento (PNUD, Haiti, 1988). 
dinâmicas socioespaciais conformadoras da metrópole haitiana pode facilmente percebê-las através da distribuição da população entre os bairros de poder aquisitivo alto e baixo, em que a precariedade da vida cotidiana é evidente. Nesse sentido, na ocasião do nosso trabalho de campo na cidade em 2017, entrevistamos um morador da cidade de Deus, em um dos bairros considerados mais pobres da cidade de Porto Príncipe. Na entrevista, perguntamos o seguinte: a seu ver quais são as principais dificuldades encontradas para morar aqui? Ele respondeu assim:

\begin{abstract}
A nosso ver, as principais dificuldades encontradas aqui se relacionam aos problemas de acesso aos serviços básicos, tais como saneamento, água potável, eletricidade, o serviço de coleta de lixo, o tratamento de esgoto. Além disso, a falta de infraestrutura, que gera tráfego para automóveis, complica enormemente o trânsito de pessoas, como também a presença de mercado nas ruas do bairro. Além de tantos de tantos outros problemas (ADLET, entrevistado, 29/01/2017) ${ }^{51}$
\end{abstract}

Com efeito, a questão do acesso aos serviços públicos básicos listados por esse morador é um dos problemas enfrentados pela maioria dos moradores de bairros pobres da região metropolitana de Porto Príncipe. Além da falta de cadastro residencial (título de propriedade), de infraestrutura, de saneamento básico e de problemas ambientais. Esses moradores que possuem esses tipos de habitação não podem reivindicar o título de propriedade da terra, pois, na maioria das vezes, são terras ocupadas em áreas de riscos onde os habitantes desses bairros aspirar dias melhores. Entretanto, eles estão expostos geograficamente a todos os riscos naturais: como terremoto, inundações, deslizamentos, desabamentos. Esse é o resultado da desigualdade, da exclusão social, da ausência continuada do Estado diante sua responsabilidade republicana e das dificuldades dessas populações em ingressar no mercado de trabalho a fim de construir uma casa descente pela realização da vida com dignidade. Pelo contrário, na maioria das vezes, essas populações são culpadas pelos governos municipal e central por estar morando em áreas de risco. Enquanto, como já vimos no projeto de requalificação urbana no âmbito da reconstrução da cidade não tem uma parte relacionada à questão habitacional no centro da cidade.

51Daprè mwen, prensipal difikilte mwen rankontre isit la nan katye se pwoblèm asenisman, jwenn sèvis kòm ramase fatra, netwaye ego yo. Anplis, nou pa gen enfraestriti koze de sa machin yo bay blokis, mache piblik nan tout ri yo e lòt pwoblem ankò (Tradução livre em língua crioulo haitiano). 


\section{Mapa 11 - Distribuição populacional na RMPP em 2016}

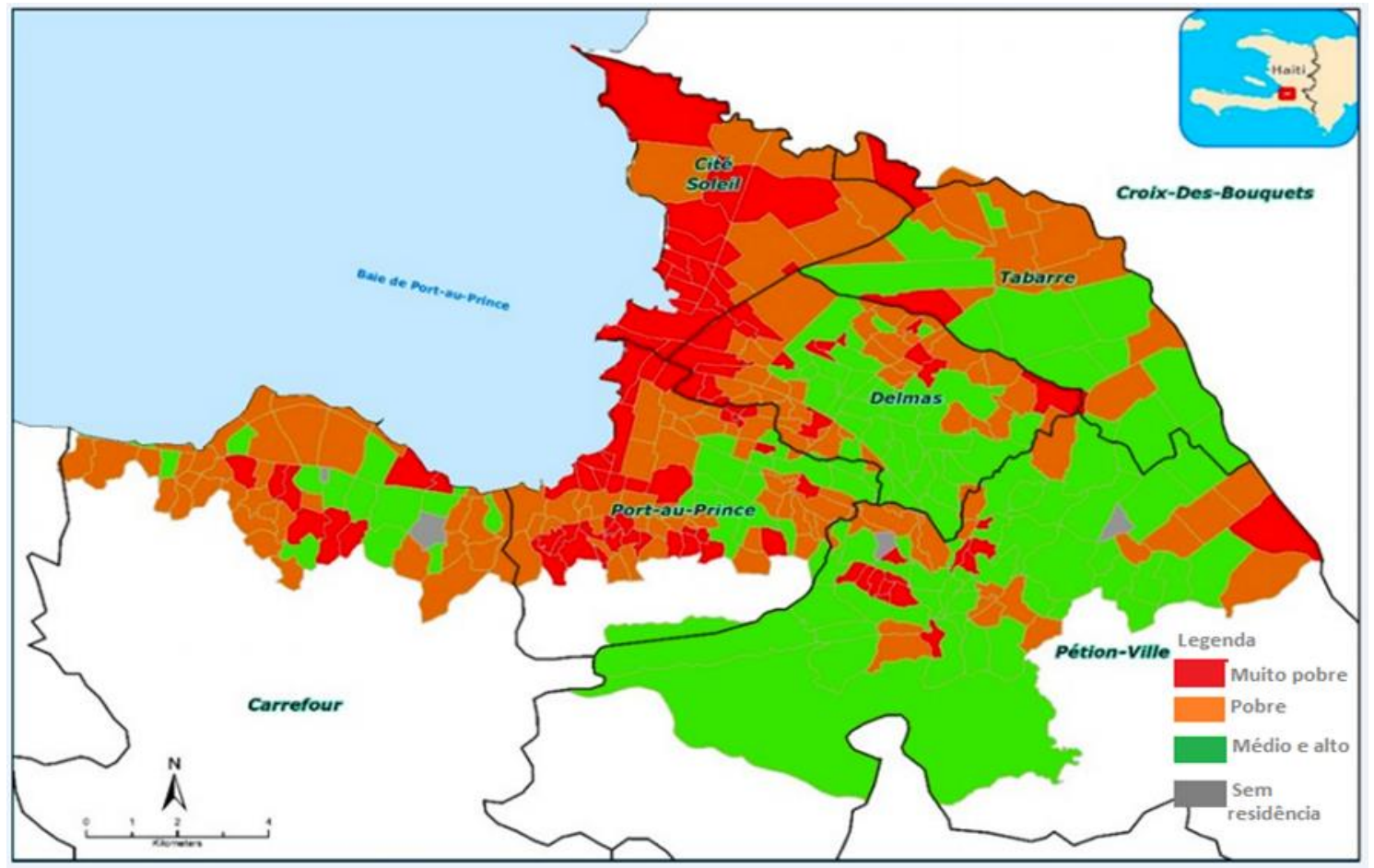

Fonte: CNSA, 2016. Adaptação: Ismane Desrosiers, 2018.

O mapa 11 apresenta desigualmente a distribuição socioespacial da população na região metropolitana de porto Príncipe em 2016. Observamos, no mapa as áreas (vermelhas) da beira do mar, principalmente, são reconhecidas como áreas onde estão localizados os bairros mais desfavorecidos em Porto Príncipe. Isso é descrito nos estudos de Lavalin (1998) e de Holly (1999) em que se vê uma alta densidade demográfica conjugada com situações de habitações precárias de telhas de ferro ondulado localizadas nessas áreas geograficamente perigosas. As famílias nesses bairros são geralmente não possuem sanitários, água potável, eletricidade, gás de cozinha. Além de não ter acesso aos serviços básicos, os bairros de habitações precárias estão situados nas ravinas, nos morros tais como: Jalousie, Jaquet Toto, (na cidade de Petion-Ville), Carrefour Feiulles, Decayette, La valée de Bourdon, Grand Ravin, entre outros, no Sul município de Porto Príncipe enfrentam problemas ambientais como deslizamento de terra no período chuvoso (ciclônico entre junho a novembro), bairros nos quais costumam ter várias vítimas nesta época do ano (HOLLY, 1999). Os mesmos tipos de bairros pobres estão situados nas áreas inundáveis como: Martissant, Cité Plus, Cité de Dieu, no oeste de Porto Príncipe.

Com efeito, o caso emblemático em termos de precariedade de habitação e de condições de vida como o todo se revela em Cité Soleil, uma das cidades da região 
metropolitana de Porto Príncipe, que é sujeita ao alagamento no período chuvoso, em que as moradias costumam ser inundadas ${ }^{52}$ e é também a mais violenta do Haiti, onde a criminalidade e a política estão intimamente interligadas. Nessas áreas são constituídos bairros, geralmente, onde as faltas de higiene, de saneamento básico, de acumulação de lixo são frequentes, problemas análogos em outros bairros pobres de todas as cidades da região metropolitana de Porto Príncipe, elas são sujeitas a todos os tipos de risco natural que sinalizaremos posteriormente.

\section{Figura 14 - Tipo de habitação nos bairros pobres na RMPP}

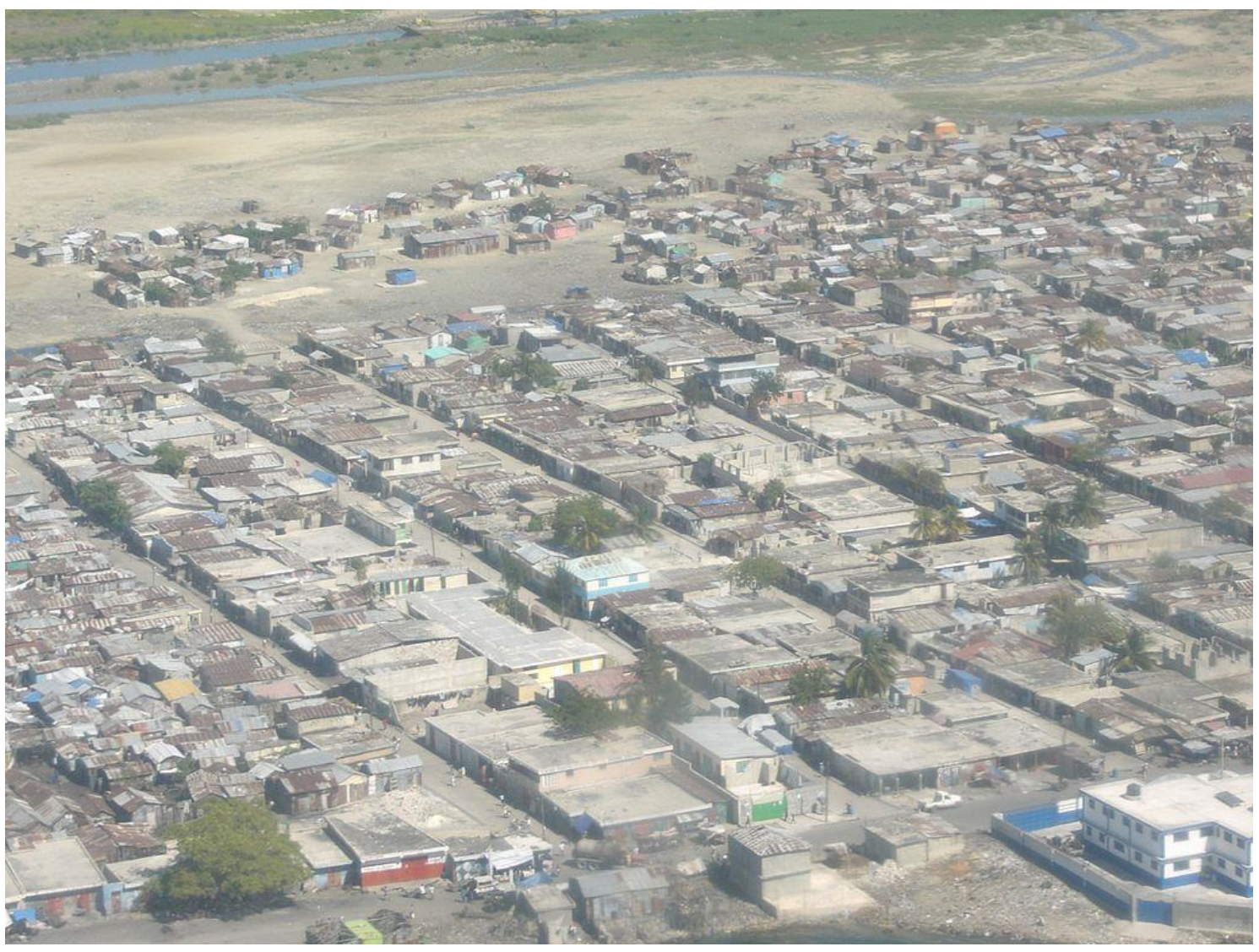

Fonte: $\quad$ https://pt.wikipedia.org/wiki/Cit\%C3\%A9_Soleil\#/media/Ficheiro:Cit\%C3\%A9_soleil.JPG. Acesso em: 31 de jul. de 2019.

A figura 14 mostra as condições de habitações em bairros desfavorecidos na região metropolitana de Porto Príncipe. Essas áreas são sujeitas aos riscos naturais

52 Os bairros da região metropolitana de Porto Príncipe estão sujeitos a uma série de riscos naturais, que os afetam de maneira diferente de acordo com sua localização geográfica e a qualidade dos edifícios. Os assentamentos nos bairros pobres são construídos em encostas íngremes nas colinas sofrem deslizamentos de terra que regularmente removem parte dos edifícios e as casas ao longo dos desfiladeiros estão expostas ao colapso das margens, erodidas pelos fluxos de água. Aqueles que vivem dentro do barranco são ameaçados pelo rápido aumento dos níveis de água e grandes depósitos de lixo. No fundo da cidade de Cité Soleil perto da costa, as casas são construídas em terrenos instáveis, consistindo no acúmulo de resíduos e sedimentos. Inundações frequentes transformaram essas áreas em áreas úmidas e insalubres. 
(terremoto, furação, enchente, deslizamento de terra) que na verdade afetam a cidade inteira. Entretanto, os habitantes da metrópole Porto Príncipe não são iguais diante desses riscos, pois a desigualdade social e a pobreza acentuam a exposição dos mais pobres. Portanto, as populações da cidade não são expostas aos mesmos graus de perigos. Isso pode ser explicado por meio da localização geográfica das habitações. Nesse sentido, essa desigualdade diante aos riscos é encontrada na escala dos bairros. Tudo isso é um dos resultados das desigualdades sociais construídas ao longo dos processos históricos, econômicos e de migrações internas perceptíveis hoje, sobre as formas de desigualdades socioespaciais. Esses processos empurram os mais pobres, os menos capazes de se protegerem contra os riscos em direção às áreas mais perigosas, mais vulneráveis, muitas vezes ao longo das margens dos barrancos (HOLLY, 1999).

Entretanto, a área verde (mapa 11) constituída de bairros, principalmente, no município de Pétion-Ville que são geralmente poucos povoados onde as classes média e média alta vivem em habitações maiores localizadas na zona leste de Porto Príncipe. Esses bairros têm melhor acesso aos serviços básicos, água, saneamento básico, ruas pavimentadas e eletricidade. Em ocasião de corte de eletricidade, por exemplo, tais bairros têm acesso à geradora de energia 24 horas em suas casas. Ali concentra uma grande parte da elite econômica haitiana. Nessa cidade considerada a mais rica do país, ficam a maioria das embaixadas, as multinacionais, os grandes comércios, os cassinos, os clubes, os hotéis e várias mansões de alto padrão. Portanto, distante (socialmente), por exemplo, dos grandes bolsões de pobreza urbana extrema como são descritos nos bairros da cidade de Cité Soleil anteriormente.

Com efeito, esses moradores abastados possuem carros de luxo importados dos Estados Unidos da América. Durante nosso trabalho de campo em 2017, a partir de observações feitas, em termos de desigualdades espaciais na região metropolitana de Porto Príncipe, podemos ilustrar estas a partir dessa hierarquia de lugares na metrópole onde a disparidade entre os grupos sociais que compartilham espaços comuns na metrópole haitiana pelas suas condições socioeconômicas é visível. Isso é evidenciada, também, de um lado, pelo grau de instrução desses moradores como mostra o gráfico (10), caracterizado pela baixa instrução que é o resultado de um processo histórico marcado pela desigualdade em termos de acesso à educação no Haiti. 


\section{Figura 15 - Centro do município de Petion-Ville}

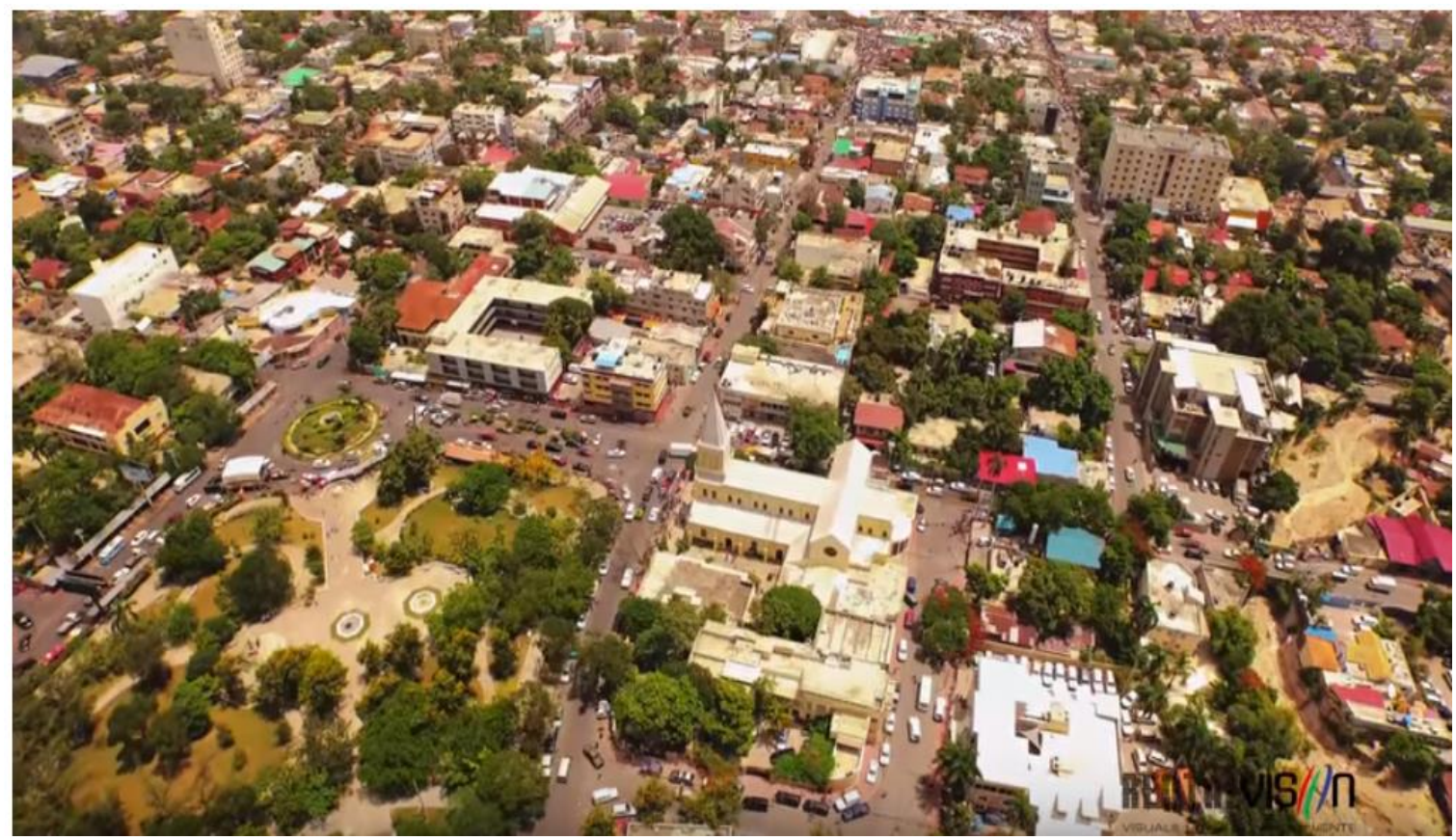

Fonte: https://www.youtube.com/watch?v=1F-LNLmQs6g. Acesso em: 30 de abr. de 2019.

\section{Gráfico 10 - Grau de instrução de moradores entrevistados em bairros}

considerados pobres da RMPP

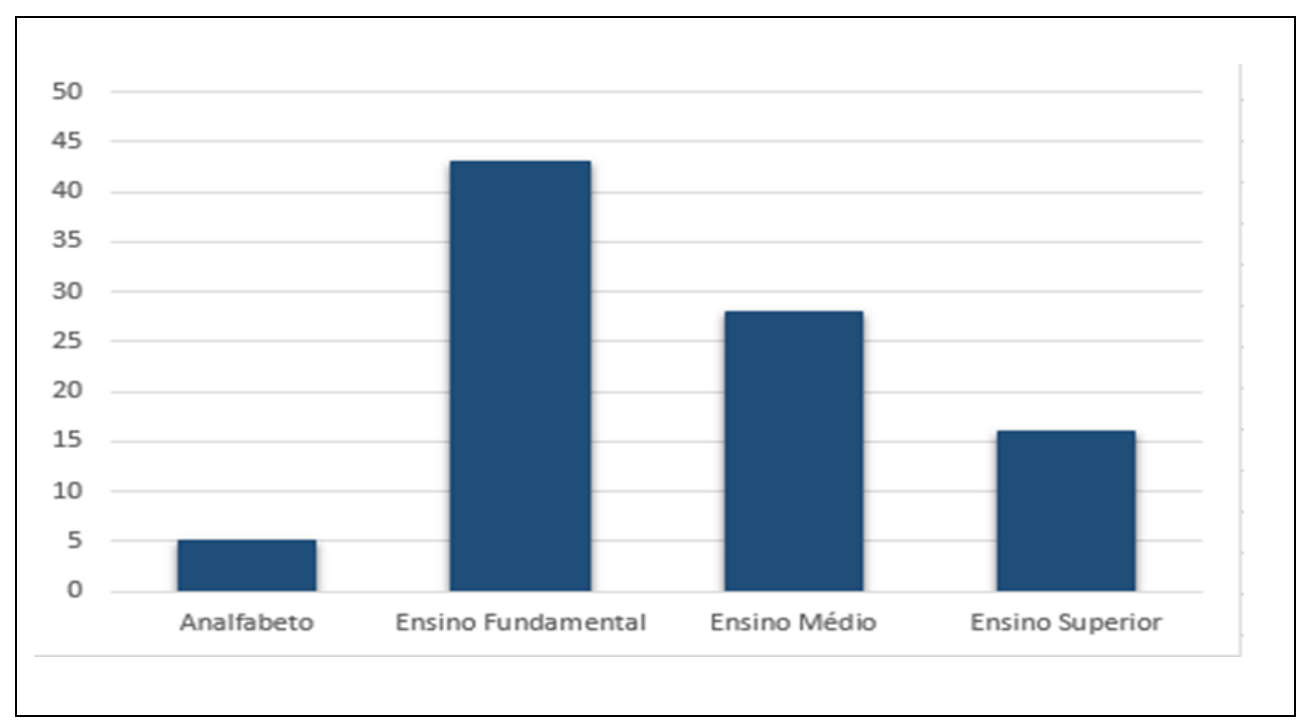

Fonte: Elaborado pelo autor baseado nos dados coletados em trabalho de campo, 2017.

Observando o gráfico (10), pode-se dizer que este é revelador de como o sistema educacional haitiano é marcado pela desigualdade entre os grupos sociais. Assim, veremos mais adiante como que, na segunda metade do século XIX, por meio do acordo do Concordat de 1860, entre o Estado haitiano e o Vaticano (a Igreja Católica), as escolas ligadas à Igreja Católica foram convidadas a ir ao Haiti para educar a juventude das elites urbanas (TROUILLOT, 1990). Isso marca a desigualdade no acesso à 
educação entre essas elites urbanas e a massa dos camponeses que vivia no campo que não está superada até hoje.

Nesse sentido, considerarmos que o nível de instrução de um indivíduo corresponde, às vezes, ao tipo da profissão praticada na sociedade. Partindo dessa ideia, durante o nosso trabalho de campo no Haiti, especialmente na cidade de Porto Príncipe entrevistamos alguns moradores de bairros considerados pobres com enfoque em suas profissões e locais de moradias. Desvendamos que esses bairros são expressão da pobreza urbana ${ }^{53}$ (SANTOS, 1978) na cidade evidenciada, pelo tipo de habitação encontrado nos diferentes partes da região metropolitana de Porto Príncipe.

\section{Gráfico 11 - Profissão de moradores entrevistados em bairros considerados pobres} da RMPP

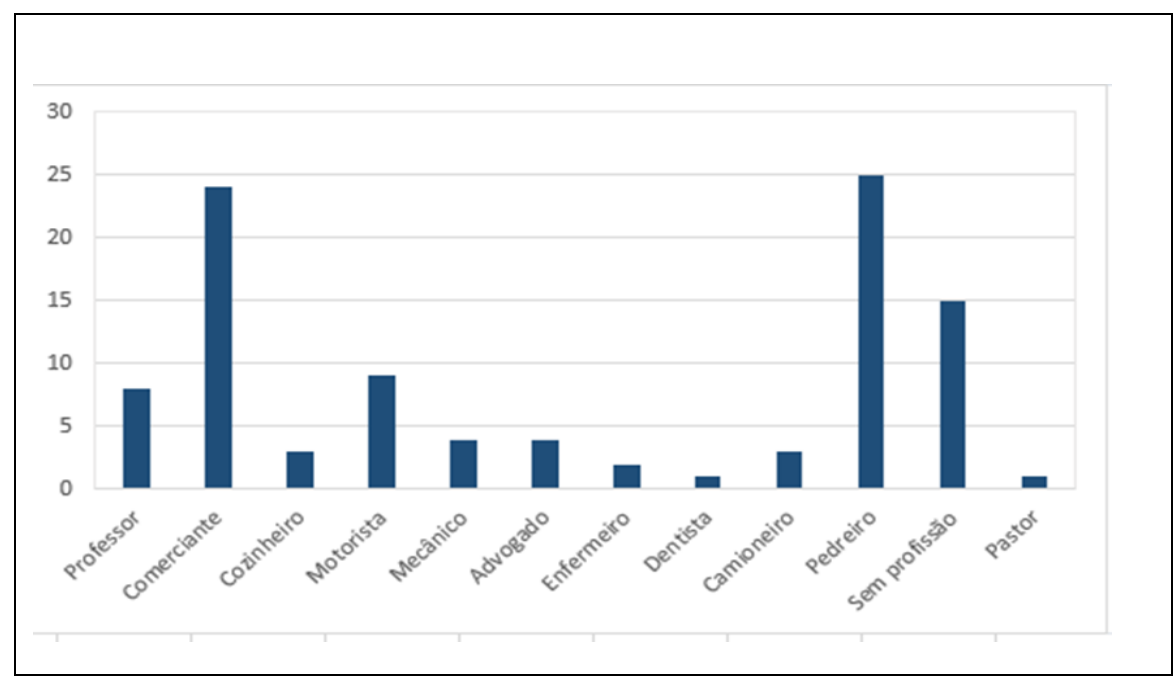

Fonte: Elaborado pelo autor baseado nos dados coletados em trabalho de campo, 2017.

O gráfico 11 apresenta tipos de profissão dos moradores entrevistados nos bairros considerados pobres da cidade. Com efeito, os bairros do grupo social de poder aquisitivo alto e médio no grande Porto Príncipe estão localizados geograficamente nas alturas de Pétion-Ville, Bel Vil, nos subúrbios da cidade de Tabarre, por exemplo, Route de Frères, Montagne Noire. Alguns desses bairros são mais antigos que outros. Eles são distinguidos, entre outras coisas, pelas casas de luxo, guardas de serviços e de segurança privada. Os moradores desses bairros de alto padrão segreguem em relação às demais populações da cidade, na medida em que se localizam em áreas de difícil acesso e cercados de muros. No nosso trabalho de campo observamos que para acessar a esses 
bairros não há transporte público coletivo. Nos bairros considerados de maior poder aquisitivo, como Bel-Vil, Vivy Mitchel e em áreas próximas ao Canapé-Vert, como Juvénat, seguranças conferem qualquer visitante por meio de câmeras de vigilância. É difícil para qualquer indivíduo acessar esses bairros nobres da região metropolitana de Porto Príncipe. Neles, existem residências que não têm nada a invejar dos bairros de alto padrão como, por exemplo, os que comportam condomínios fechados na cidade de São Paulo ou em qualquer outra metrópole de países em desenvolvimento na América Latina e no Caribe.

Figura 16 - Tipo de habitação nos bairros ricos na RMPP

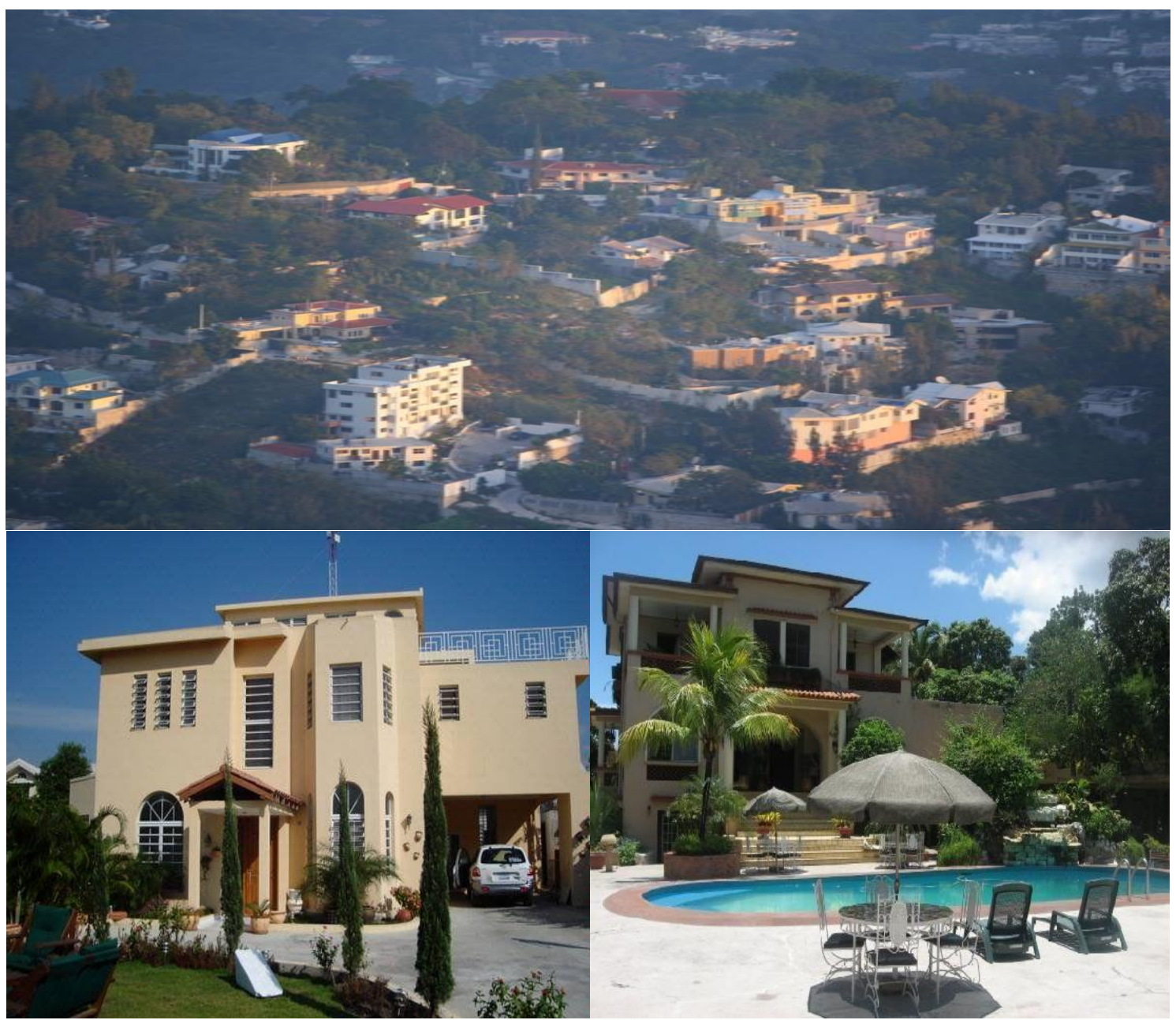

Fonte: Organização: Ismane Desrosiers, 2018.

A figura 16 mostra alguns tipos de habitação da classe média da região metropolitana de Porto Príncipe. Na ocasião do trabalho de campo entrevistamos, também, alguns moradores de bairros considerados ricos na região metropolitana de Porto Príncipe sobre seu grau de instrução por uma melhor fundamentação da nossa análise acerca das desigualdades socioespaciais na metrópole haitiana. Em qualquer sociedade, a educação como tal representa a base do desenvolvimento social. Dessa 
maneira, a educação, de algo modo, define qualquer projeto social que visa o desenvolvimento socioeconômico. A nível educacional, a teoria da reprodução está principalmente associada segundo Bourdieu (1986) $)^{54}$, citado por François $(2009)^{55}$ às estruturas sociais que evidenciam as relações de dominação existentes nas sociedades. Veremos mais adiante que no Haiti existe um sistema educacional historicamente desigual concebido pelo Estado e da Igreja Católica. Essa situação é reforçada pela inserção no Haiti de escolas internacionais como Lycée Français (da França) e a Unio School Haiti (dos Estados Unidos da América). Nessas escolas mais da metade de seus estudantes são haitianos pertencentes à classe rica onde cremos que a cultura e os valores haitianos não são ensinados, portanto são lugares da reprodução do grupo dominante.

\section{Gráfico 12 - Grau de instrução de moradores entrevistados em alguns bairros ricos} na RMPP

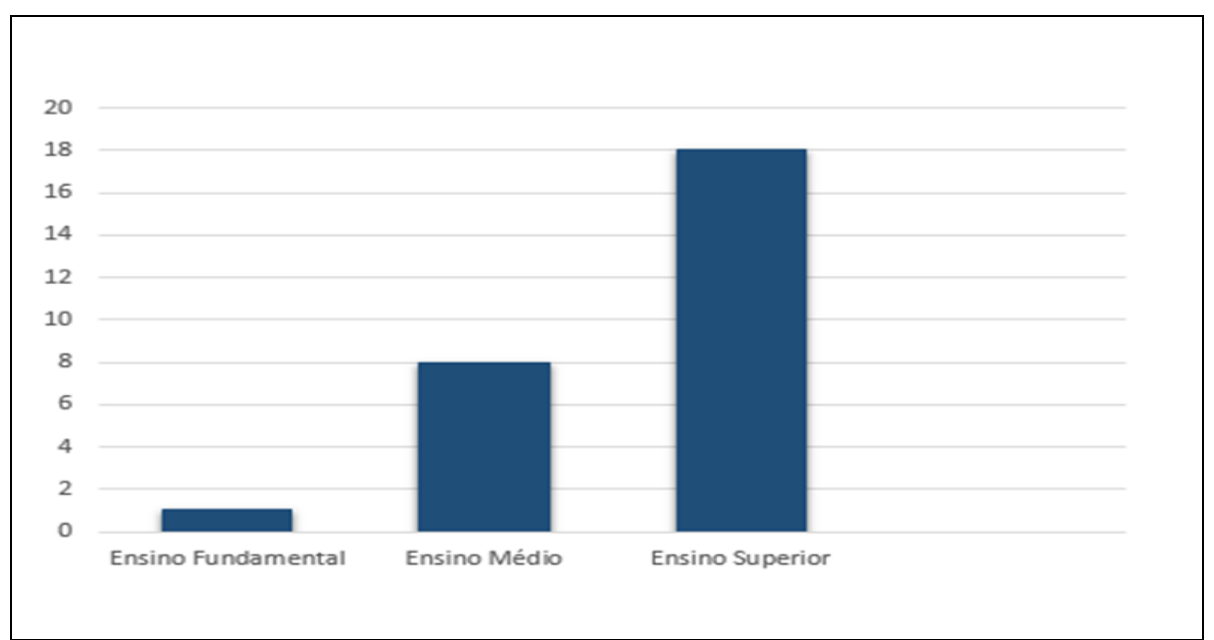

Fonte: Elaborado pelo autor baseado nos dados coletados em trabalho de campo, 2017.

Partindo da reflexão de Pierre Bourdieu (1986), a educação de qualidade a favor de uma classe em detrimento de uma outra é um dos instrumentos para manter as desigualdades sociais na sociedade. Nesse sentido, desvendamos que no Haiti há uma educação privada reservada para os filhos da classe dominante, pública e privada École borlette (loteria), parte inferior da hierarquia para os alunos da classe dominada. No entanto, a educação em um país como o nosso deveria ser o elemento de cimento social que pode promover o desenvolvimento e a emergência do homem haitiano. Nesse sentido, pode-se dizer que o acesso desigual à educação tem influência nos tipos de

54 Bourdieu, P. Habitus, code et codification, Actes de la recherche en sciences sociales. 1986, pp. 40-44. 55 François, P. E. Système éducatif et abandon social en Haïti. Cas des enfants et des jeunes de la rue. Thèse de Doctorat en Sciences de l'éducation. Paris: Université de Paris 10 Nanterre. 2009. 
profissão de moradores que entrevistamos na região metropolitana de Porto Príncipe nesses bairros favorecidos da metrópole.

\section{Gráfico 13 - Profissão de moradores entrevistados em bairros considerados ricos} da RMPP

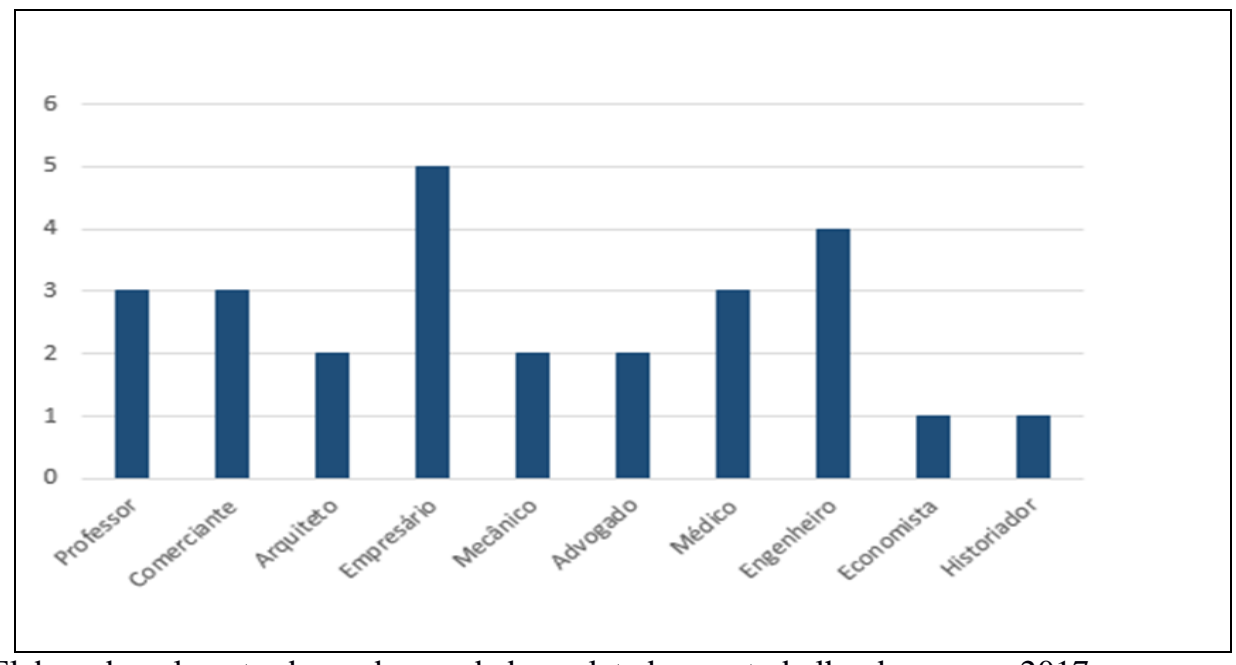

Fonte: Elaborado pelo autor baseado nos dados coletados em trabalho de campo, 2017.

Com efeito, comparando gráficos 10, 11, 12 e 13, percebemos que as desigualdades se manifestam além da distribuição da população na cidade de Porto Príncipe. Dessa maneira, o fenômeno faz presente, também, em termos de grau de instrução e de tipos de profissão de moradores que entrevistamos durante o nosso trabalho de campo em 2017. Outro dado importante no que tange às desigualdades na cidade é a distribuição de renda (CNSA, 2009) ${ }^{56}$. Segundo dados do Conselho Nacional de Segurança Alimentar (CNSA, 2009), existem seis fontes de renda básicas para a maioria dos moradores de bairros considerados pobres da região metropolitana de Porto Príncipe, tais como: trabalho de rua, mão de obra informal, emprego assalariado, pequenos negócios/pequenas empresas e média. O trabalho de rua ambulante representava os grupos sociais pobres e extremamente pobres. Em contraste ao emprego assalariado que tem segurança no emprego são, principalmente, moradores associados ao salário médio e alto cujos dados não são disponíveis. Contudo, é evidente que a renda desses moradores é muito superior do que os grupos desfavorecidos, portanto, menos qualificados. Esta disparidade em relação à renda pode ser evidenciada pela localização dos bairros, pelas más condições de vida da maioria da população que vive em bairros desfavorecidos na metrópole Porto Príncipe. 


\subsection{Dinâmica da economia urbana em Porto Príncipe desde 1980}

Por uma melhor compreensão da situação econômica urbana e de emprego na cidade de Porto Príncipe na contemporaneidade, é importante que façamos uma análise crítica da dinâmica da economia haitiana em si, nos últimos 30 anos. Com efeito, nos anos de 1950 até a da década de 1970, com o legado da Exposição Universal de 1949, realizada na cidade de Porto Príncipe, a economia do turismo foi importante na constituição do PIB do país. Isso é demostrado pelo número de visitantes que aumentou de 159.954 em 1972 para 303.414 em 1979, e as receitas aumentaram de US\$ 16,7 milhões, em 1973 para US\$ 61,8 milhões, em 1979 (ANGLADE, 1982). Além disso, milhares de empregos foram criados nas indústrias, principalmente, no setor do têxtil.

Assim, a partir de 1980, o Haiti conheceu um período de instabilidade política e de estagnação econômica, culminando em 1986 com a queda do governo ditatorial dos Duvalier e o início do processo de democratização do país. Dentro desse contexto de crise política, econômica e social dos anos de 1980, o Haiti aceita inserir-se na política neoliberal abrindo seu mercado nacional à concorrência internacional. Contudo, essa política foi imposta ao país como ao conjunto dos países da América Latina e do Caribe pelo Banco Mundial (BM) e o Fundo Monetário Internacional (FMI) em resposta à crise econômica mundial que começou em 1973 com o primeiro choque do petróleo. Tudo isso, no sentido de achar uma solução para a crise do welfare state, restaurando os postulados liberais, sob o nome do neoliberalismo com ascensão ao poder de Ronald Reagan, nos EUA (1981) e, da $1^{\text {a }}$ Ministra Margareth Thatcher, no Reino Unido (19791990). Segundo Harvey $(2008)^{57}$, o termo neoliberalismo é compreendido como uma teoria das práticas político-econômicas que propõem que o bem estar humano deve se assentar nas liberdades e capacidades empreendedoras individuais, com uma intervenção mínima do Estado na economia. Nos anos de 1980, com o Plano de Ajustamento Estrutural (PAS) imposto a toda região por meio de instituições de Bretton Woods, tais como: Banco Mundial (BM), Fundo Monetário Internacional (FMI), Banco Interamericano de Desenvolvimento (BID) promoveram receituário "prescrito" por essas instituições, os símbolos de tais políticas do neoliberalismo definido como Consenso de Washington ${ }^{58}$ no final da década de 1980.

57 O neoliberalismo: história e implicações. São Paulo, Loyola, 2008.

58Disponível em: https://mundoeducacao.bol.uol.com.br/geografia/consenso-washington.htm Acesso em: 15 de ago. de 2018. 
Além das instituições de financiamentos internacionais (IFI) mencionadas anteriormente, o Haiti tem acordos e convenções concluídas entre os países África, Caribe e Pacífico (ACP) e da União Europeia (UE). Portanto, veremos mais adiante na pesquisa como a partir da sua inserção no neoliberalismo causa uma concorrência desigual diante de outros países, em particular, Estados Unidos da América, EUA. Ademais, o empréstimo para seu "desenvolvimento" é condicionado a elevar o padrão do FMI e do Banco Mundial o que faz com que desde nos anos de 1980, o Haiti mantém a dependência econômica que impede, de alguma forma, sua capacidade de atingir um nível de crescimento das atividades produtivas compatível aos desafios que a sociedade enfrenta nos dias de hoje. De um lado, a dependência econômica, as desigualdades, os aprofundamentos da pobreza coincidem com o processo de liberalização comercial dos anos 80 com a aceitação de seguir os planos, programas e acordos com o FMI dos anos 1982/1983; 1984/1985, 1986/87; 1989/1990 (DOURA, 2002). Em 1991, através da resolução ${ }^{59}$ 46/7, a Organização dos Estados Americanos (OEA) e da Organização das Nações Unidades (ONU) decretaram embargo ${ }^{60}$ econômico contra o (Haiti) o governo militar que, por meio de um golpe de estado depôs, o presidente Jean Bertrand Aristide, eleito democraticamente, em 1990. Esse embargo terminou, em 1993, portanto, isso reforça as dificuldades socioeconômicas do país (BAZABAS, 1997, p. 32).

Contudo, cabe mencionar que até 1980, a produção nacional foi protegida por barreiras tarifárias, particularmente, elevada sobre determinados produtos estratégicos que os governos subsidiaram. Nesse sentido, a produção nacional foi capaz de satisfazer a demanda interna por vários produtos agrícolas, em particular, os mais consumidos, por exemplo, arroz, feijão, carne, açúcar e farina. Entretanto, com a aplicação das políticas do neoliberalismo e o embargo dos anos de 1990, a economia do país conhece uma situação de estagnação conjugada com o endividamento externo como indica o gráfico 15. A aplicação das políticas neoliberais contribui na "destruição" do sistema de produção nacional e a diminuição drástica de imposto sobre a importação, todo isso, sofre impacto sobre a economia urbana da cidade de Porto Príncipe.

59 Disponível em: https://digitallibrary.un.org/record/153638/files/A_47_599-FR.pdf . Acesso em: 5 de set. de 2018.

60 O embargo imposto ao Haiti pelas Nações Unidas, em 1991, era para forçar um retorno à ordem constitucional (retorno do presidente Aristide ao poder no Haiti). Durante este período, grande número de indústrias de subcontratação foram realocadas, a moeda depreciou-se significativamente, o déficit público aumentou, a inflação acelerou-se e o PIB real diminuiu. Em 1992, o Haiti experimentou uma das menores taxas de crescimento de sua história (-1,38\%). Os anos de 1991 a 1993 representam o período em que os indicadores econômicos atingiram seu nível mais baixo (BAZABAS, 1997). 
Gráfico 15 - Dívida externa do Haiti em milhões de dólares de 1970 até 2006

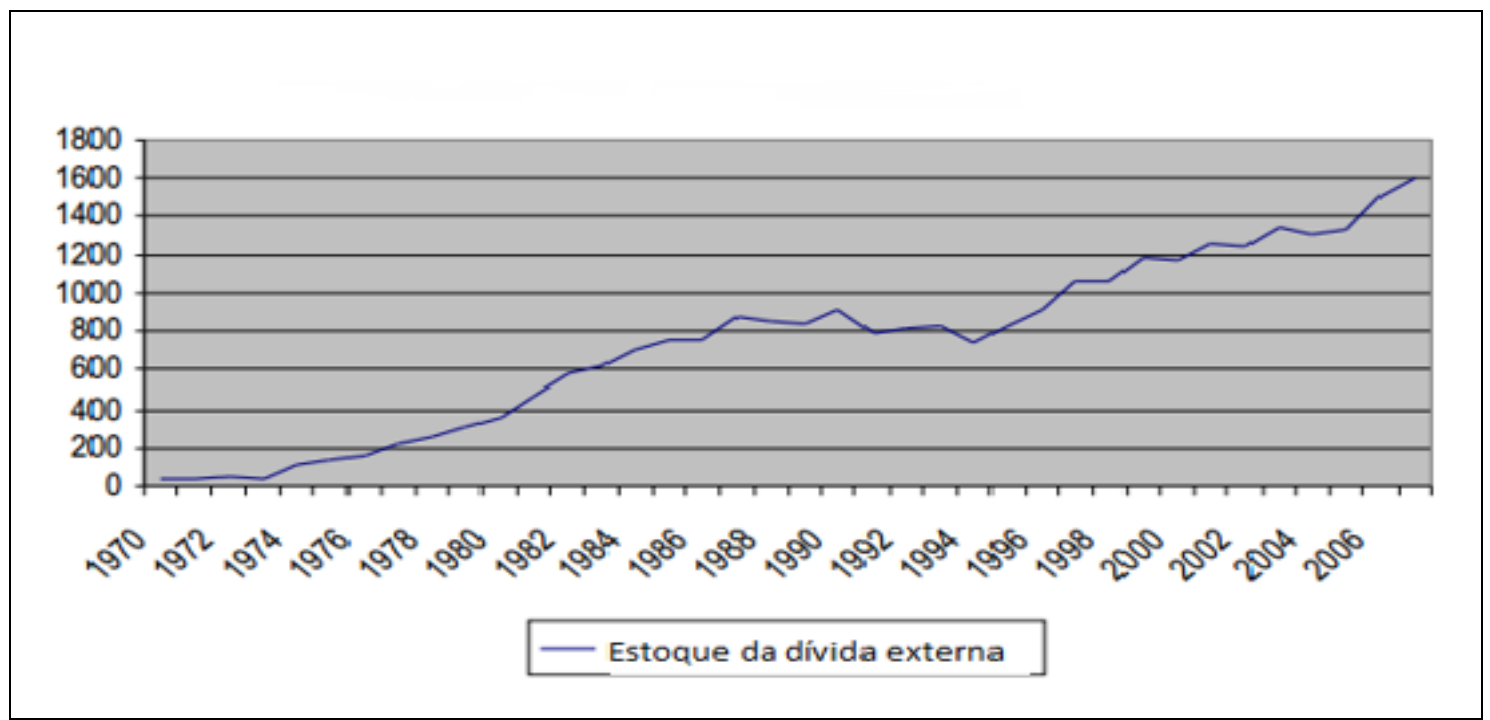

Fonte: Banco Mundial, Global Development Finance, 2009.

O gráfico 15 mostra o crescimento da dívida externa do Haiti a partir da adoção das políticas neoliberais nos anos de 1980 e o embargo econômico sobre o país no início da década de 1990. Dessa maneira, com a inserção do país no neoliberalismo entre 1986 e 1987, um plano de ajustamento estrutural, foi elaborado pelo Banco Mundial e do Fundo Monetário Internacional em que as autoridades haitianas diminuíram as tarifas alfandegárias. Assim, o mercado nacional foi rapidamente invadido por produtos estrangeiros altamente subsidiados, particularmente, dos Estados Unidos (DOURA, 2002). O caso do arroz que está na base da dieta haitiana é emblemático, pois, depois de um novo acordo de ajustamento estrutural assinado com o FMI, em 1995 e entrada do país junto à Organização Mundial do Comércio (OMC) no mesmo ano; as tarifas, por exemplo, sobre o arroz passassem de 50\% para 3\% (HENRY et al 2005). Dessa maneira, evidenciamos, como a empresa estadunidense, Miami Rice, inundou o mercado haitiano e o resultado disso é que esse país de 11 milhões de habitantes hoje ocupa $4^{\circ}$ lugar no ranking de países importadores de arroz dos EUA ${ }^{61}$. Portanto, a queda nas tarifas exigidas pela $\mathrm{OMC}$ tem como consequência a descapitalização dos pequenos agricultores, empobrecimento do campo o que, a nosso ver, acelera o fluxo migratório no processo de urbanização, ao mesmo tempo, afeta a produção nacional. Contudo, o Haiti era autossuficiente do ponto de vista alimentar até a década de 1980, passa a importar em 2008, por exemplo, 82\% de seu consumo de arroz (DOURA,2002).

61 Fonte: Disponível em http://www.cadtm.org/Le-marche-haitien-du-riz-un-cas Acesso em: 12 de ago. de 2018. 
De acordo com Henry et al (2005), a Organização Mundial de Comércio é um instrumento criado para sustentar as políticas neoliberais. No sentido de completar a dupla do Fundo Monetário Internacional e do Banco Mundial (FMI/BM). Para esses autores, essas instituições de financiamentos internacionais acentuam brutalmente a desregulamentação da economia haitiana afetando toda base da produção nacional. Tudo isso, pode ser evidenciado a partir de medidas que direcionaram as tarifas sobre os produtos agrícolas, que passaram de $200 \%$ para menos de $50 \%$, antes de ver seu nível crescente de desmantelamento, caracterizado pela redução acentuada das tarifas em meados dos anos de 1990, para seus níveis mais baixos de 0\%, 3\%, 5\%, 10\% 15\% por cento (IRAM, 1998, HENRY et al, 2005). A consolidação de 0\% por cento tarifa diz respeito a vários produtos agrícolas e pecuários, especialmente leite e iogurte. Portanto, as exigências das IFIs de abrir os mercados nacionais à livre concorrência estrangeira contribuem na estagnação da economia nacional, pois, o Haiti torna-se um dos países mais liberais da América Latina e do Caribe (DOURA, 2002).

$\mathrm{O}$ arroz dos EUA altamente subsidiado pelo governo norte-americano inundou o mercado local, por conseguinte, os preços foram puxados para baixo e, a produção local de arroz desmoronou gradualmente como mostra o Gráfico 16 . Ou seja, a redução de tarifas e a abertura do país ao comércio exterior levaram a um acesso descontrolado dos produtos alimentares importados. Em outras palavras, houve o aumento constante das importações por uma parte da elite econômica haitiana que atua no setor de importação. Por que os importadores não investem na produção dos produtos importados?

Gráfico 16 - Produção e importação de arroz proveniente dos EUA de 1985 a 1999

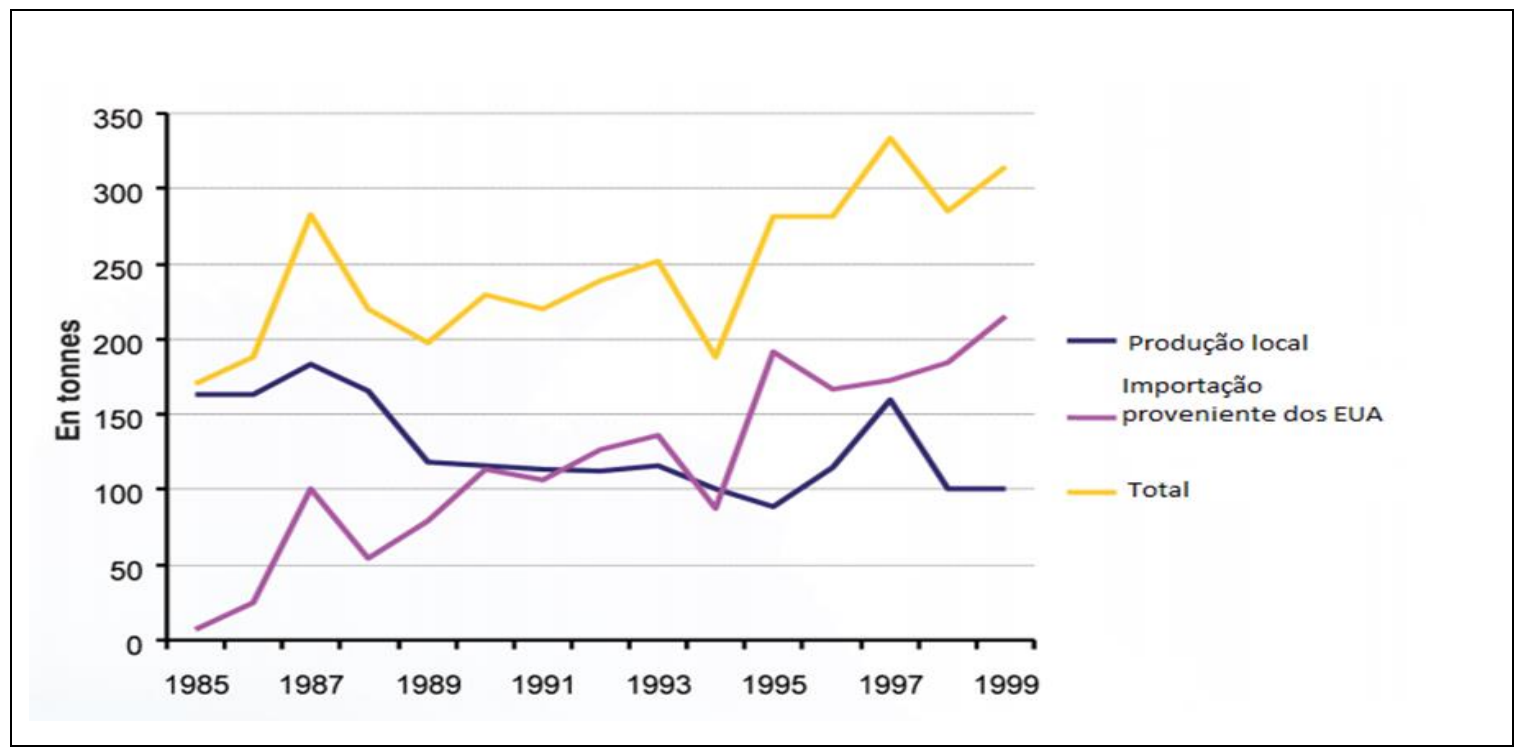

Fonte: Departamento de Comércio dos EUA, Escritório do Censo dos EUA, Estatísticas do Comércio Exterior, Ministério da Agricultura e de Desenvolvimento Rural, FAO, 2000. 
O gráfico 16 mostra o consumo de arroz no Haiti destacando a produção local desse produto e a importação em toneladas proveniente dos EUA. É possível nele observar que a quantidade de arroz importado, principalmente, de 1993 a 1999 é superior do que foi produzido localmente e a tendência continua até nos dias de hoje. As barreiras de importação permitem que o Estado proteja tanto a produção doméstica quanto a arrecadação de fundos. No entanto, as diminuições das tarifas sobre as importações dos produtos agrícolas impediam, de algo modo, o Estado de arrecadar impostos para responder às necessidades básicas da população.

Articulamos a inserção do Haiti no neoliberalismo a partir da lógica da vantagem comparativa $^{62}$ (RICARDO, 1878). Essa é uma teoria descrita pelo economista clássico David Ricardo (1772-1823) que pressupõe, em um contexto de livre comércio, que cada país, se especializa em algum produto e aumenta sua produtividade. Essa produção gera uma "vantagem comparativa". O país continua a ser um exportador de produtos de valor agregado e seus parceiros comerciais continuam sendo importadores desses produtos como os de agrícolas. Por conseguinte, dialogando com Ricardo (1878) podemos dizer que o Haiti, na sua concorrência comercial no liberalismo com outros países, principalmente com os Estados Unidos da América desde 1980, é um exemplo concreto de um país importador de produtos de valor agregado em uma dinâmica de vantagem comparativa a favor dos EUA.

Contudo, os produtos importados tiveram papeis importantes na composição do Produto Interno Bruto (PIB) do Haiti antes da sua incorporação ao neoliberalismo. Segundo IHSI (2006), o PIB do país constitui-se de um conjunto de setores de atividades econômicas, sendo estes: o setor primário que inclui agricultura, silvicultura, pecuária, pesca e mineração que por vários anos vem declinando. Sua contribuição para o PIB está encolhendo cada vez mais. Consequentemente isso é devido ao contínuo declínio da produção agrícola sob o efeito da liberalização do mercado nacional, a agricultura é espremida e não pode resistir à concorrência de produtos importados. À vista disso, a participação da agricultura no PIB passou de mais de 50\% em 1975/76 para menos de 30\% em 2006. Paradoxalmente, a agricultura é uma fileira do setor primário que empregava a maioria da população ativa no Haiti (IHSI, 2006).

62 A teoria da vantagem comparativa é uma teoria tradicional do comércio internacional modelada por David Ricardo em 1878 em seu livro: Os Princípios de Economia Política e Tributação. Em inglês: The principle of political economy and taxation". HENRY HOLT \& CO. NEW YORK, 1878. 
O setor secundário, por sua vez, incluindo as indústrias de manufatura, eletricidade, construção e obras públicas, não representa um grande componente do PIB devido ao baixo nível de investimento no Haiti, seja o investimento direto estrangeiro ou investimento local. Na última década, esse setor não contribui significativamente para o crescimento do PIB. Sua participação no PIB continua, em média, em torno de 15\%. Esse setor, também, não é um importante provedor de empregos na economia. E, por fim, o setor terciário reagrupando, comércio, restaurantes e hotéis, transporte e comunicações e serviços de mercado (IHSI, 2006). Portanto, a contribuição desse setor para o PIB está em constante crescimento como indica o gráfico 17.

A entrada no mercado de novos operadores no setor de comunicação ajuda a dinamizar o setor. A grande novidade a que assistimos na economia nacional é que, em todos os países, onde o setor terciário está mudando, tem um efeito positivo em outros setores. Mas, ironicamente, no Haiti, o setor terciário ${ }^{63}$ está em desconexão com outros setores da economia. Isso pode ser explicado, em decorrência da preponderância do comércio de produtos importados e pelo uso desses produtos como matérias-primas no setor de alimentação. As atividades comerciais de restaurante e hotéis representavam mais de 50\% das atividades econômicas do setor terciário (IHSI, MEF, 2006).

\section{Gráfico 17- Tendência e a composição setorial do PIB haitiano entre 1800 a 2009}

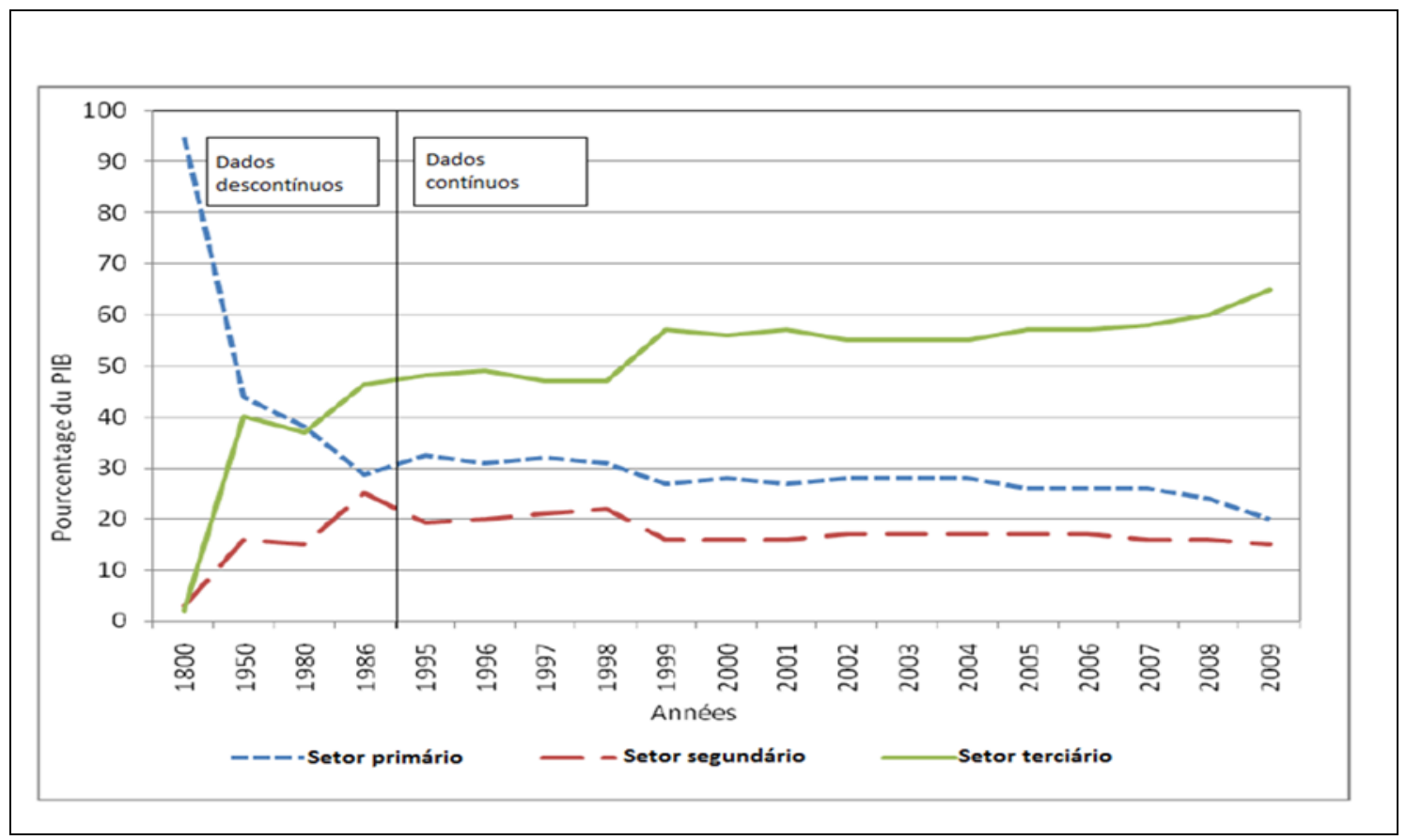

Fonte: Instituto Haitiano de Estatística e Informática (IHSI), 2010.

$63 \mathrm{O}$ setor terciário corresponde ao desenvolvimento e à expansão do setor de serviços na economia em detrimento dos demais setores de atividades econômicas no Haiti (IHSI, 2010). 
O gráfico 17 mostra a dinâmica de diferentes setores de atividades econômicas que compõem o PIB do Haiti entre 1800 a 2009. Na época da proclamação da independência, em 1804, a principal fonte da economia era a terra e, como resultado, as atividades agrícolas eram a principal ocupação da força de trabalho no século XIX. Dados estatísticos revelaram que, em 1800, a agricultura representava de cerca de $95 \%$ do PIB do país. Mais tarde, os dados do primeiro censo de 1950 apontavam que a população total do país era de 3.097.220, compreendendo uma população ativa de 1.705.139 habitantes, distribuída da seguinte forma: $85,7 \%$ na agricultura, $56 \%$ nas atividades secundárias e $8,5 \%$ no setor de serviços e $0,2 \%$ por cento ocupavam nas atividades desconhecidas (IHSI, 1950). Portanto, a economia do país evoluiu para uma rápida terceirização, passando de uma base essencialmente agrícola (café, cacau, cana de açúcar, sisal, feijão, milho e sorgo) para uma outra, de domínio do setor terciário.

Dessa maneira, o setor terciário está se tornando cada vez mais importante, passando de 49\% do PIB em 1995 para 58\% em 2014 (IHSI, MEF, 2016). Por conseguinte, esse setor tem uma contribuição significativa no PIB de 1980 até ocorrer o terremoto de 2010. Tudo isso, no contexto de urbanização acelerada e do crescimento populacional do país, pois, segundo dados do IHSI (2010), a população ativa no Haiti aumentou de 2.348.605 em 1980 para 4.246.689 em 2010, com uma taxa de crescimento anual média de 2,69\% por cento entre 1980 e 2010, em comparação com uma taxa de crescimento da população total em média de $2,5 \%$ no mesmo período.

Todavia, as atividades econômicas no setor terciário não conseguem atender à crescente demanda por emprego dos jovens à procura de trabalho cada ano. Dados mais recentes do IHSI mostram que o Haiti tem o menor nível de PIB per capita na América Latina e do caribe estimado em torno de US\$ 830/habitante com um salário mínimo $^{64}$ de cerca de 200 dólares por mês em 2017. O subemprego continua a ser a forma dominante de desemprego, como em todos os países de renda muito baixa, onde praticamente lá não existe um sistema de previdência social. Entretanto, segundo IHSI (2012), a metade da população haitiana tem menos de 21 anos de idade. Desse modo, a idade média da população é de 25,4 anos como indica a pirâmide etária em 2012.

64 O salário mínimo no Haiti é calculado de acordo com os segmentos de atividades econômicas para o ano de 2018. Mais informações sobre os salários mínimos segundo os segmentos de atividades são disponíveis em: http://www.loophaiti.com/content/haiti-entre-350-500-gdes-les-nouveaux-salairesminima-sont-connus Acesso em: 20 de fev. de 2019. 
Gráfico 18 - Pirâmide etária da população haitiana em 2012

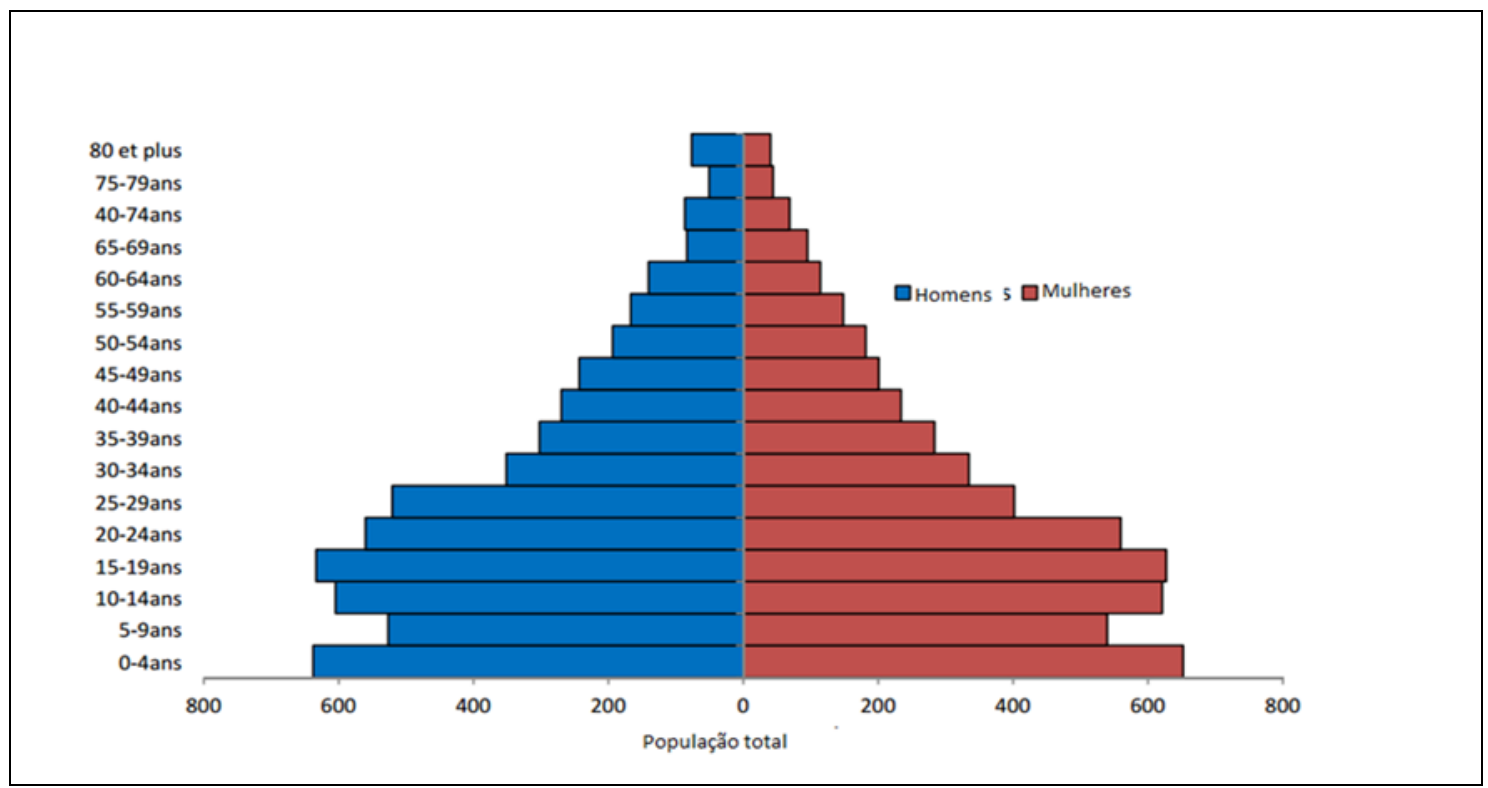

Fonte: IHSI, ECVMAS, 2012.

O gráfico 18 apresenta o comportamento demográfico da população haitiana, em 2012, em que mais de 220.000 jovens são adicionados à população em idade ativa (245.000 se considerarmos 14 anos, em vez de 10 anos), colocando, assim, uma forte pressão no mercado de trabalho para aqueles que procuram um emprego. A taxa de desemprego expandida, calculada pelo IHSI, foi de $18,3 \%$ e $34,2 \%$ na região metropolitana de Porto Príncipe, o que afetou principalmente os jovens de menos de 30 anos (70\%). Foi estimado em 1999, pela Organização Internacional do Trabalho (OIT) no Haiti, em colaboração com o Ministério do Planejamento e Cooperação Externa (MPCE), que o subemprego afetou aproximadamente $51 \%$ da população ativa (OIT, MPCE, 1999). Nos setores secundário e terciário, existiam cerca de 114.000 empregos $^{65}$ formais.

Nesse sentido, a questão de desemprego é, de alguma forma, ligada à aplicação dos planos, programas e acordos das instituições de financiamentos internacionais. Com efeito, aplicando o plano do neoliberalismo, em maio de 1998, o governo haitiano seguindo as diretrizes do FMI e do BM adotou a lei de "Despedida e Retirada Voluntária Antecipada do Serviço Público". Portanto, como parte de sua implementação do plano, 5.200 servidores públicos, ou seja, $10 \%$ dos funcionários do governo foram exonerados $^{66}$. Dessa forma, aqueles que eram empregados, a partir desta decisão foram

65 Em 1999, foram registrados 36.000 empregos no setor público e 78.000 no setor privado (IHSI, 1999). 66 A carta de intenção do governo haitiano ao Diretor, gerente do FMI, Michel Camdessus. Disponível em: http://www.imf.org. Acesso em: 22 de ago. de 2018. 
adicionados à força de trabalho desempregada em que a maioria dos quais recorrem às atividades de subsistência informal (DOURA, 2002).

Por conseguinte, se, de um lado, o plano da política neoliberal causou a remoção de $10 \%$ dos funcionários públicos, por outro, governo também privatizou várias empresas estatais, como a fábrica de farinha do Haiti Minotrie d'Haiti e a empresa de cimento do Haiti Cimentrie Nationale (CINA). Outras empresas públicas como Portos, Aeroporto Internacional de Porto Príncipe, Telecomunicações e Eletricidade do Haiti também foram objetos de privatização. Mas os movimentos sociais impediram, de algum modo, que essas instituições fossem privatizadas. A questão de desemprego é um dos desafios encontrados no Haiti, sobretudo, entre os jovens de 15 a 30 anos.

Notam-se, então, as dificuldades de inserção dos jovens no mercado de trabalho registrado e assalariado, principalmente, na metrópole Porto Príncipe enquanto maior polo de atração em termos de oferta de emprego. Entretanto, a metrópole não consegue atender a grande demanda por emprego. Isso foi mostrado na hierarquia das taxas de desemprego no país comparando entre as cidades capitais nas provinciais e a metrópole Porto Príncipe onde $52,1 \%$ da população ativa estava desempregada (IHSI, EEEI, 2007). A taxa de desemprego é duas vezes maior do que a de outras cidades provinciais do país. Bazabas (1997) descreve essa situação na cidade da seguinte forma:

Numa cidade como Porto Príncipe, o recente chegado ou o jovem urbano não têm outras escolhas que de produzir para sobreviver e esperar viver melhor. No entanto, esse polo urbano não dispõe empresas o forte potencial de mão de obra podendo empregar o não urbano e não qualificado que desembarque. Mesmo o Estado emprega pouco e desde muitos anos, os capitais privados estrangeiros não vieram mais aproveitar de custos vantajosos da mão de obra haitiana (BAZABAS, 1997, p.83).

No entanto, a taxa de crescimento da população ativa é uma oportunidade para o Haiti caso o país consiga educar essa juventude e criar as oportunidades de trabalho para aumentar o poder aquisitivo e diminuir as desigualdades sociais no Haiti. 


\section{Gráfico 19 - Taxa de crescimento da população total e da população ativa entre 1990 e 2015.}

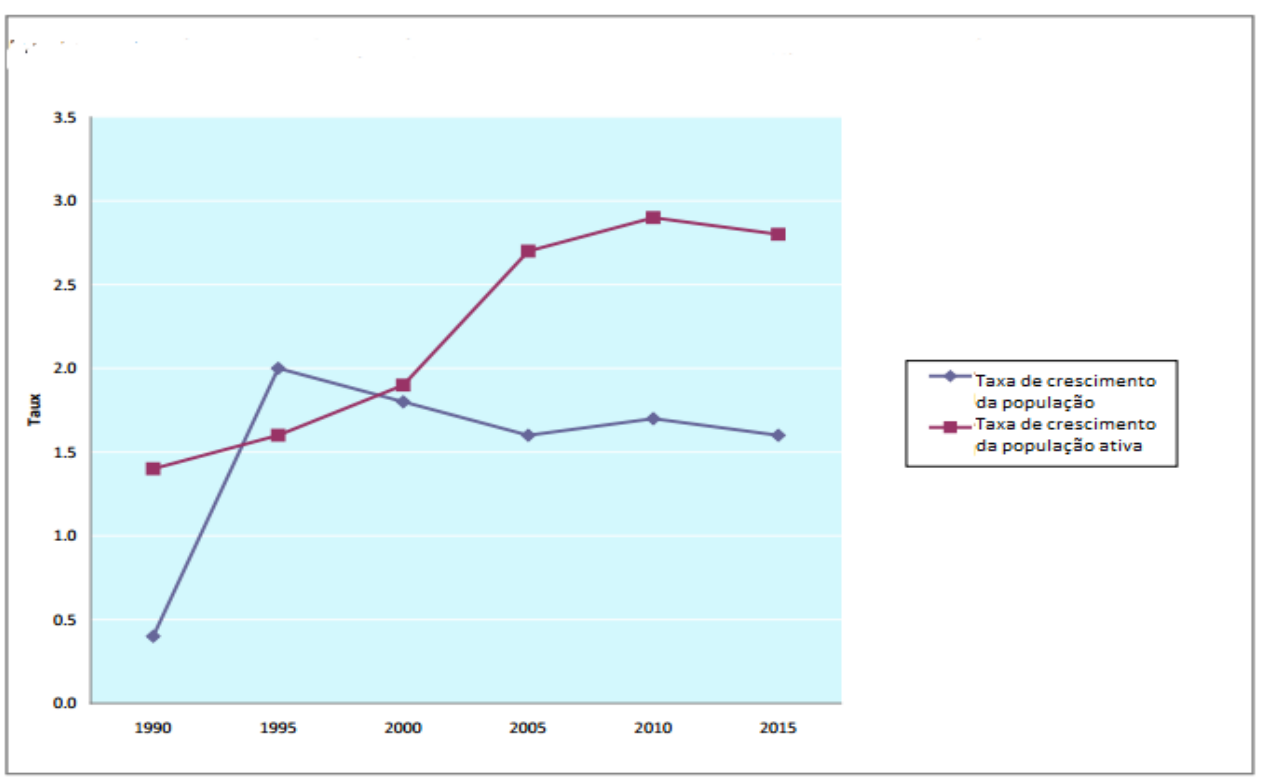

Fonte: IHSI, 2015

Como indica o gráfico 19, a taxa de crescimento da população total e da população ativa mostra que o Haiti está em condições de aproveitar um dividendo demográfico, pois a população economicamente ativa está crescendo mais rapidamente do que a população dependente ${ }^{67}$. Mas, devido à falta de produção, o país não consegue aproveitar esta força de trabalho e a metrópole Porto Príncipe que incorpora como lugar de realização de sonho e de emancipação social está atraindo um grande contingente de população migrante composto, principalmente, por jovens. Este potencial dividendo demográfico cresce a cada ano em que o país, em particular a metrópole, não oferece a esses jovens oportunidades. Por conseguinte, isso gera emigrações desses para outros países, notadamente, nos da América Latina, sobretudo, no Brasil após 2010.

A urbanização acelerada, a centralização em Porto Príncipe e a inserção do Haiti no neoliberalismo causam impactos significativos na cidade de Porto Príncipe. Desta forma, uma situação de informalidade na economia urbana "definida" claramente a partir da década de 1980. Para melhor compreensão da reprodução da desigualdade na economia urbana dos países subdesenvolvidos, geógrafos passaram a analisar as cidades através de dois subsistemas da economia urbana: o circuito superior ou "moderno" e o circuito inferior ou marginal. Nesse sentido, o geógrafo brasileiro Milton Santos, no seu

67 Proporção entre o número de membros de 0 a 14 anos e maiores de 65 anos e o número de associados entre 15 e 64 anos que representa a população ativa. 
livro intitulado O Espaço Dividido: os Dois Circuitos da Economia Urbana dos Países Subdesenvolvidos, disse que a economia urbana deve estudar como um sistema único, mas composto de dois subsistemas que ele chama de circuito superior e o circuito inferior da economia urbana (SANTOS, 2008).

O circuito inferior é constituído por forma de fabricação "não capital intensivo" pelos serviços não modernos e de pequena dimensão (SANTOS, 2008, p. 41). O circuito superior, por sua vez, pode distinguir atividades "puras", "impura" e mista, como a indústria urbana moderna, o comércio e os serviços modernos no caso das atividades "puras" do circuito superior. A indústria de exportação assim como o comércio de exportação são atividades "impuras". Além disso, ele disse que o banco poderia ser incluído nesta classificação, como traço de união entre as atividades modernas da cidade e as cidades maiores do país e o exterior. Em termos de atividade mista, Milton Santos, na sua explicação afirma que os atacadistas e transportadores têm atividades do tipo misto pelo fato de sua dupla ligação entre o circuito superior e o circuito inferior da economia urbana (Ibdem, 2008, p.41). Portanto, segundo o autor, o circuito superior utiliza uma tecnologia importada e de alto nível, uma tecnologia "capital intensivo", enquanto no circuito inferior a tecnologia é "trabalho intensivo" e frequentemente recriado. Afirma-se que:

O circuito superior emana diretamente da modernização tecnológica, mais bem representada atualmente, nos monopólios, não está ligado ao local ou regional, mas sim dentro da estrutura de um país ou de países. O circuito inferior é formado de atividades de pequena escala, servindo, principalmente, à população pobre; ao contrário do que ocorre no circuito superior, essas atividades são profundamente implantadas dentro da cidade, usufruindo de um relacionamento privilegiado com sua região (SANTOS, 2008, p. 43).

No entanto, aqui a nossa análise sobre a e economia urbana da cidade de Porto Príncipe não pretende caracterizar a economia urbana a partir de dois circuitos. Mas, de preferência uma análise inspirada na teoria de dois circuitos da economia urbana proposta por Santos (2008) respeitando a historicidade das camadas de saber, o primeiro movimento desse campo de estudos urbanos nos anos de 1970. Nessa direção, a nossa análise é demostrar quais são as atividades que movimentam a economia na cidade na atualidade. No sentido de evidenciar como as desigualdades sociais, o neoliberalismo, a urbanização levou a uma estrutura da economia urbana marcada por informalidade generalizada promovida, sobretudo, pelas camadas menos favorecidas na estrutura urbana da metrópole Porto Príncipe em busca de sobrevivência. 
Com efeito, a informalidade na economia urbana cresce à medida que o país se urbaniza, pois dados do censo ${ }^{68}$ do IHSI (1950) mostram que, por volta de 1950, a cidade Porto Príncipe e sua região metropolitana tiveram uma taxa de urbanização $8 \%$. A partir dessa década houve o movimento de êxodo rural de haitianos em busca de oportunidades de emprego na cidade, principalmente na indústria têxtil (BAZABAS, 1997). Entre 1971 e 1982, esse setor da indústria gerou dois terços do emprego formal e registrado no contexto de urbanização do Haiti, o crescimento demográfico e a centralização das atividades econômicas em Porto Príncipe. Sem desenvolver suficientemente outros ramos na indústria, a cidade não consegue atender à crescente demanda por emprego dos recém-chegados na metrópole.

Por conseguinte, diante dessa situação Porto Príncipe começa a conhecer um processo de informalidade na economia urbana com a participação do trabalho autônomo aumentando 27\% a 33,6\% (IHSI, 1982). Dessa maneira, desde 1980, há uma extensão do emprego ${ }^{69}$ na economia informal representando, em 2000, mais de 50\% dos empregos em Porto Príncipe (IHSI, 2003). Nesse sentido, cabe mencionar que a atividade econômica na cidade de Porto Príncipe não é homogênea, pois há desde microempresas que oferecem empregos sem registro até empresas "modernas" que não estão registradas na prefeitura, portanto, elas fazem parte da economia informal (IHSI, 2003). Entretanto, considerando a importância do setor financeiro na economia de um país, principalmente as contribuições do crédito ao setor privado, a falta de acesso ao crédito no Haiti contribui para a informalidade da economia urbana de Porto Príncipe. Qual é o papel do crédito na economia haitiana? Quem tem acesso ao crédito no Haiti?

Cabe salientar que existem diferentes formas de crédito: de um lado, há crédito ao consumidor, por outro, há crédito à produção. Esse último é concedido às empresas para facilitar seu desenvolvimento, financiando seus investimentos produtivos. Os estudos de Schumpeter (1912) ${ }^{70}$ mostram que os serviços financeiros são fundamentais para promover o crescimento econômico. Segundo o autor, a produção requer crédito para se materializar.

68 Disponível em: https://www.worldcat.org/title/recensement-general-de-la-republique-dhaiti-aout1950/oclc/77695452. Acesso em: 25 de mar. de 2019.

69 No Haiti, as últimas operações estatísticas que oferecem dados sobre o emprego e as condições de vida dos agregados familiares foram realizadas pelo IHSI, antes do terremoto de 2010. Sendo estes: Enquete de Orçamento e Consumo das Famílias (EBCM, 1999-2000), com o apoio técnico do Instituto Nacional de Estatística e Estudos Econômicos da França (INSEE). Enquete sobre as Condições de Vida no Haiti (ECVH, 2001), Enquete sobre as Condições de Vida no Haiti (ECVH, 2003).

70 The Theory of Economic Development, 1912. 
No entanto, no Haiti as instituições de microfinanças e cooperativas de poupança e crédito compartilham as amplas atividades econômicas do setor terciário e frequentemente trabalham no setor informal. Suas atividades concentram-se (neste caso da região metropolitana de Porto Príncipe e no comércio) $90 \%$ das atividades financiadas pelo setor como um todo. Desse modo, o acesso ao crédito é discriminatório no sentido de que não é aberta a todos, ou seja, é reservada por uma minoria de pessoas jurídicas. De acordo com dados do Banco Central, cerca de 10\% dos mutuários do sistema bancário haitiano beneficiaram-se de aproximadamente $80 \%$ do total de crédito contra 68\% por cento em 2004 (BRH, 2004). É uma expressão da concentração de acesso ao crédito dos agentes da econômica formal.

Nesse sentido, a informalidade da economia na cidade, segundo Doura (2002), conhece uma proliferação no espaço urbano da metrópole Porto Príncipe a partir de dois fatores. De um lado, as políticas macroeconômicas caóticas das oligarquias dominantes desde a independência do Haiti em 1804. Por outro lado, as políticas neoliberais da década de 1980 e 1990 que foram aplicadas em favor das minorias, destruindo a base da produção nacional. Isso contribuiu ainda mais para a exclusão social maciça, criando assim desigualdades entre ricos e pobres (Ibidem, 2002). Isso pode ser evidenciado por meio de comércio de rua generalizado na cidade de Porto Príncipe que é, a nosso ver, é uma alternativa de sobrevivência dos desfavorecidos na cidade diante das desigualdades no acesso ao crédito, problema de desemprego e subemprego. Conforme aponta Bazabas (1997), na cidade de Porto Príncipe:

Hoje o mercado de rua ocupa um espaço importante do centro histórico de Porto Príncipe e, sobre diferentes formas uma vez que, a população economicamente ativa está desempregada. Às vezes esta atividade informal é chamada de anárquica e anti-urbana, porém, esse fenômeno constitui uma componente essencial da paisagem urbana e um elemento ativo do funcionamento socioeconômico do centro histórico de Porto Príncipe, da região metropolitana e por extensão do país como todo (BAZABAS, 1997, p. 82).

De acordo com Anglade (1982), o centro de Porto Príncipe se movimenta todos os dias para servir outro subconjunto da sua região metropolitana. Isso quer dizer, as Madan sara $^{71}$, se adaptam a esse movimento organizacional do comércio para oferecer produtos agrícolas (frutas, verduras, grãos) à cidade vindo todo dia da área rural

71 Madan sara na maioria são mulheres dos pequenos agricultores e transportadores motorizados responsáveis pelos circuitos de conexão da oferta dos produtos agrícolas aos mercados de rua e das redes de supermercados na região metropolitana de Porto Príncipe. 
próxima dos municípios que constitui a região metropolitana de Porto Príncipe. Os mercados de rua abertos diariamente em Porto Príncipe completam este movimento de troca oferecendo, por sua vez, produtos manufaturados às madan sara (BAZABAS, 1997, p. 22). Os movimentos de pessoas na cidade são para uma parte significativa das viagens relacionadas com a venda e compra de alimentos; isto é facilmente concebido pela preocupação permanente da grande maioria dos habitantes na região metropolitana em desenvolver um tipo de atividade econômica para sua sobrevivência cotidianamente. Segundo Bazabas $(1997)^{72}$, os mercados abertos no centro da cidade de Porto Príncipe funcionam como um verdadeiro polo, gerando na sua periferia a emergência de uma série de atividades comerciais com armazenagem de produtos agrícolas locais e importados, principalmente, dos EUA, tais como: bananas, feijão, arroz, carne, peixe, legumes, frutas produtos agroindustriais como açúcar, farinha, óleo de cozinha. Esse movimento é muito intenso em torno do mercado municipal como indica a figura 17.

\section{Figura 17 - Mercado municipal no centro histórico de Porto Príncipe em 2011}

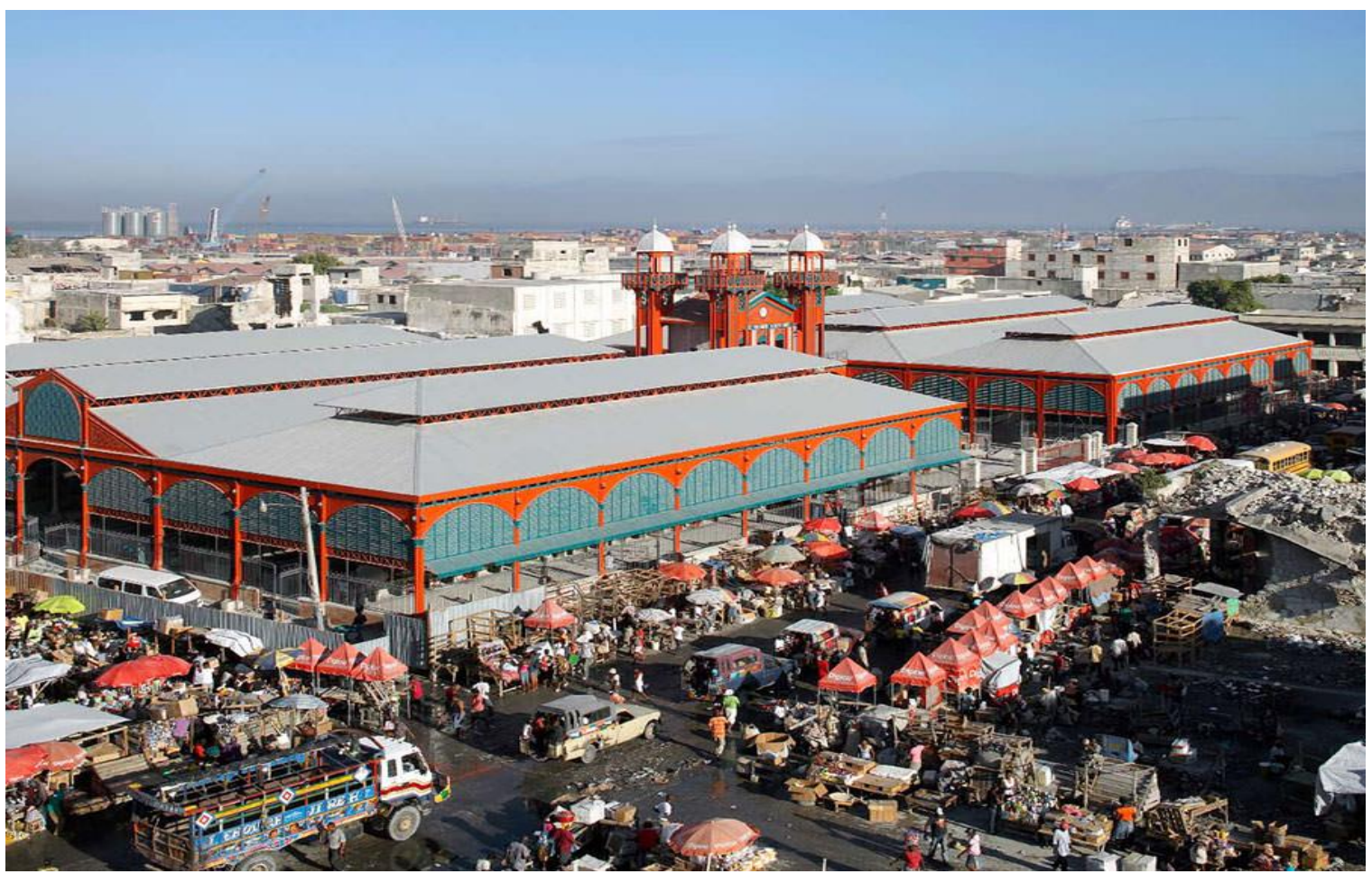

Fonte: http:///preconstruction-of-the-historic-marche-en-fer-iron-market/ Acesso em: 20 de fev. de 2019.

A figura 17 mostra o mercado municipal de Porto Príncipe. Trata-se de uma construção datada de 1890, tendo sido inaugurada em 1891, pelo então presidente Florvil Hyppolite. Esse mercado é classificado como Patrimônio Nacional e tem papel

72 Du marché de rue en Haïti. Le système urbain de Port-au-Prince face à des entreprises « d'espace rue ». L'harmattan, 1997, 124 pages. 
importante na economia urbana informal da cidade, em que comerciantes vendiam seus produtos como meio de subsistência. Fortemente danificado pelo terremoto que devastou a cidade Porto Príncipe, em 12 de janeiro de 2010, o mercado foi restaurado em 2011 graças a um investimento de US\$ 18 milhões da empresa de telecomunicação Digicel. Tudo isso, com a mesma aparência original da estrutura do ano da sua construção de 1891. Sendo a primeira obra pública reconstruída na cidade após a catástrofe de 2010. Do ponto de vista da economia urbana formal, portanto, que cria empregos formais e registrados há empresas nacionais e internacionais como as de telecomunicações, rede de hotéis, indústrias ${ }^{73}$, bancos comerciais, empresas de venda de bens e serviços; o comércio, atividades de exportação e importação, escritórios de serviços. As empresas de telecomunicações são duas: Digicel Group (Unigestion Holding S.A) empresa irlandesa funcionando no Haiti desde 2006.

\section{Figura 18 - Sede central da DIGICEL S.A em de Porto Príncipe}

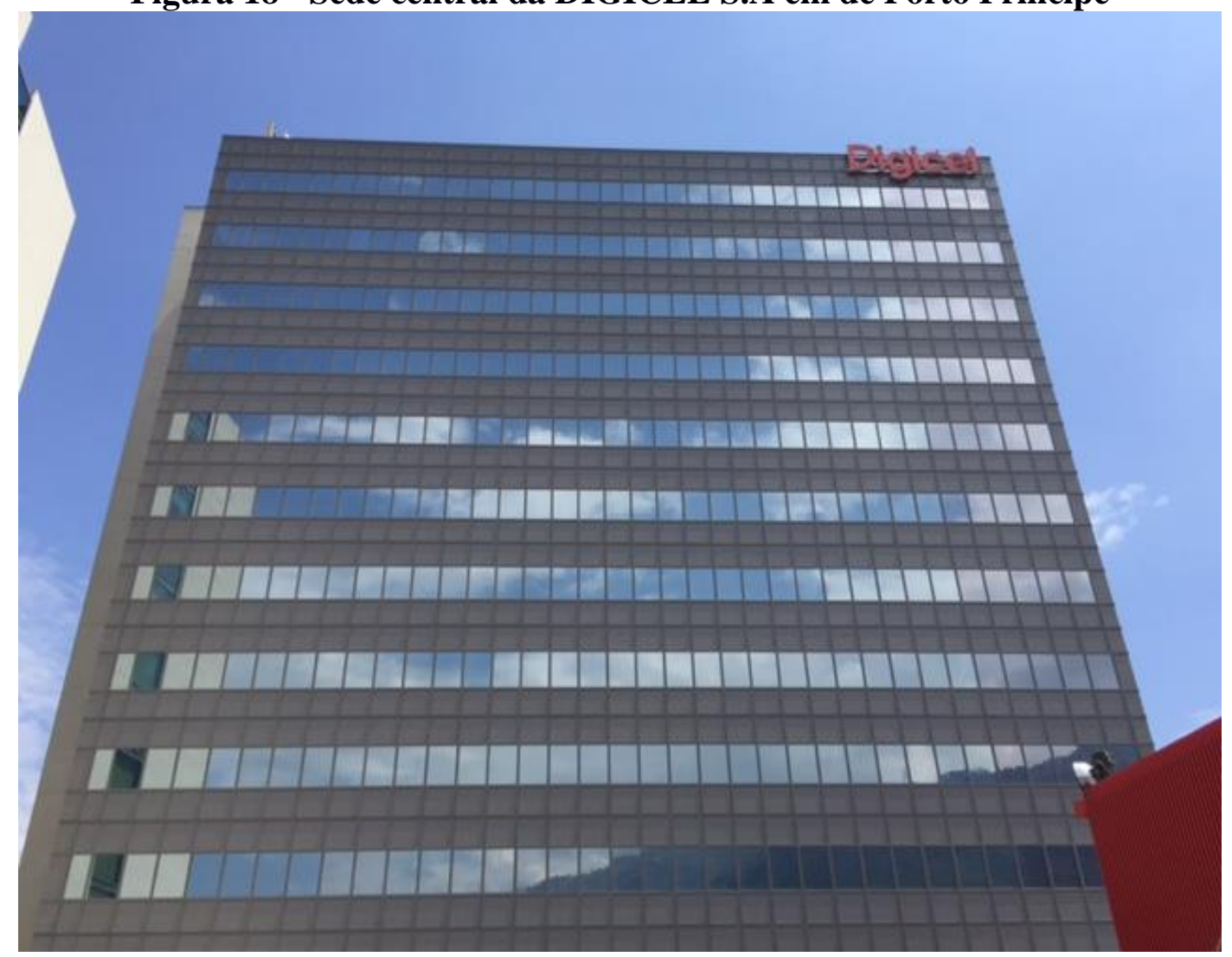

Fonte: Trabalho de campo, 2017.

73 A indústria deveria ser o setor da economia para geração de empregos na economia urbana na metrópole de Porto Príncipe, onde concentra a maior população urbana do Haiti, mas o governo haitiano se recusa a falar sobre emprego no setor industrial. Contudo, nós sabemos que as causas de não desenvolvimento da indústria nacional são mais profundas pelo próprio processo de formação socioespacial do Haiti que se agrava com a dinâmica do neoliberalismo. Como resultado, a indústria "nacional" é condicionada e orientada a uma valorização dos interesses das elites empresariais globais em detrimento da indústria nacional. 
A figura 18 mostra a sede central da companhia telefônica Digicel S.A. A outra empresa é a Companhia Nacional de Telecomunicações S.A (Natcom), um consórcio público privado criado, em abril de 2010, entre o Viettel Telecommunications Group do Vietnã (60\%), e o governo haitiano (40\%). Essas duas empresas revolucionaram o setor de telecomunicações no Haiti, sendo a primeira desde em 2006 e a segunda lançou seus serviços no Haiti, 2011.

\section{Figura 19 - Sede central da Natcom S.A em Porto Príncipe}

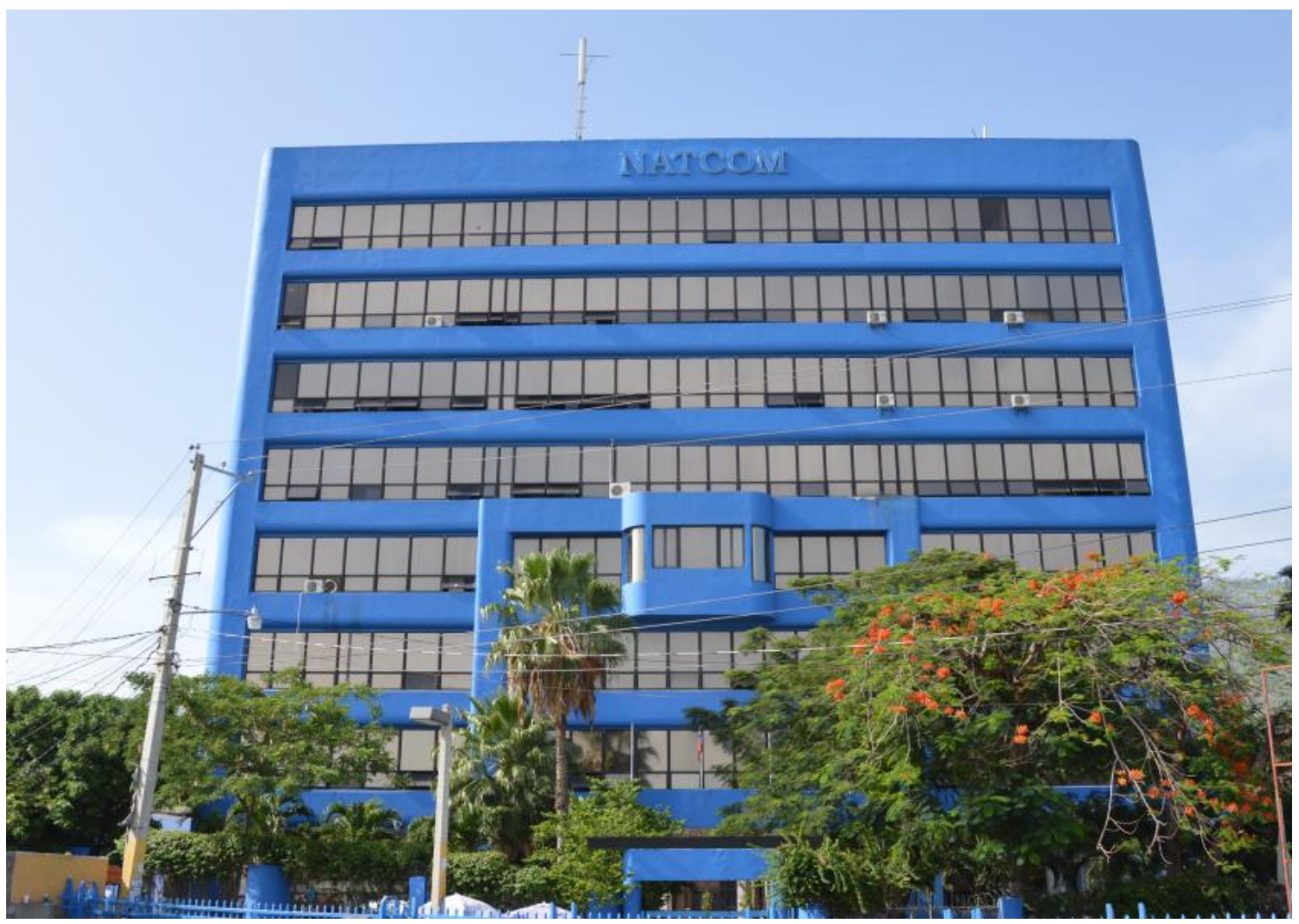

Fonte: Trabalho de campo, 2017.

A figura 19 apresenta a sede central da companhia telefônica Natcom S.A. Atualmente é o maior projeto de investimento estrangeiro pós-terremoto no Haiti que mudou fundamentalmente o panorama das telecomunicações no Haiti. Foi fornecida banda larga de alta velocidade através de sua rede de 3.500 quilômetros de cabo de fibra ótica de banda larga em todo o território haitiano, o que proporciona estabilidade de alta velocidade e conexão internet de alta qualidade. Quem tem acesso aos serviços de alta qualidade oferecidos por esta empresa na cidade?

A economia urbana da cidade de Porto Príncipe conta, também, com a indústria, por exemplo, a da manufatureira cujas atividades envolviam principalmente a 
fabricação de peças de reposição eletrônicas, produtos têxteis, bebidas. O setor têxtil, por exemplo, é responsável por mais 90\% de exportações do país (BM, 2014).

Em 2006, o parlamento dos EUA votou um acordo comercial chamado de Haiti Hemispheric Opportunity Through Partnership Encouragement Act (HOPE I), que permitia ao Haiti exportar produtos têxteis para o mercado americano. Em 2007, o HOPE I foi revisado, em o HOPE II, em seguida se tornou o HELP. Essas leis tinham como objetivo comum fornecer acesso ampliado a franquias e, ao mesmo tempo, reduzir as restrições às regras de origem e às importações de matérias-primas. Os impactos dessas políticas foram significativos uma vez que o Haiti se classifica como o $9^{\circ}$ fornecedor de vestuário nos EUA em 2009. Contudo, salientamos que as leis HOPE I e HOPE II incorporam o alinhamento neoliberal imposto ao governo haitiano em troca de assistência financeira das Instituições de Financiamentos Internacionais como o Banco Mundial, o FMI e do próprio governo dos Estados Unidos. Segundo a Associação das Indústrias do Haiti, a lei HOPE II foi destinada a promover a criação de 100.000 empregos $^{74}$ no setor da indústria têxtil em três anos com isenção de taxas alfandegárias da entrada de mercadorias nos Estados Unidos (ADIH, 2009).

\section{Figura 20 - Parque industrial metropolitano PIM}

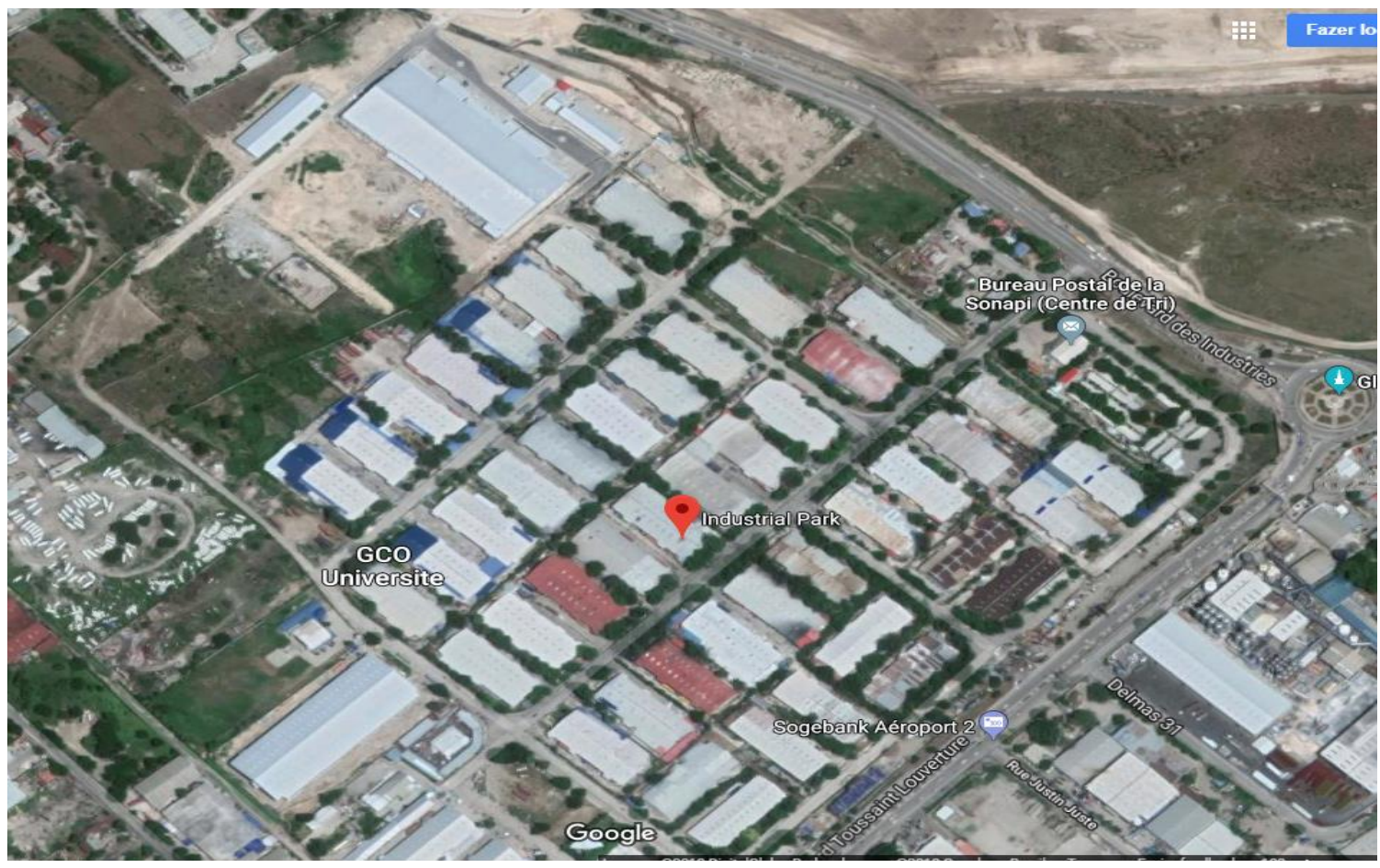

Fonte: Google Earth. Acesso em: 25 de fev. de 2019.

74 Segundo a Associação das Indústrias do Haiti (ADIH), em janeiro de 2017, esse setor representa 41 mil empregos. Mais informações disponíveis em: https://lenouvelliste.com/article/173405/le-secteurtextile-haitien-est-il-victime-dun-grand-nom. Acesso em: 15 de set. de 2018. 
A figura 20 mostra o parque industrial metropolitano em expansão após o terremoto de 2010. O setor têxtil dinamizou a economia urbana favorecida pelo aumento da demanda dos EUA e aumentou o nível de emprego, passando de 31.424, em outubro de 2013 para 41.188 em setembro de 2015, um aumento de $31 \%$. A produção na indústria têxtil está concentrada em três parques principais: o Parque Industrial Metropolitano (PIM), em Porto Príncipe, Parque Industrial Caracol (PIC) e o Parque Industrial Ouanaminthen (Nordeste do país) que constitui a Sociedade Nacional de Parques Industriais (SONAPI). Representa-se em média, 285 milhões de metros quadrados em volume, com um valor médio de US\$ 721 milhões entre 2010 e 2015 (MEF, 2016). A produção industrial haitiana neste setor é competitiva em $t$-shirt, camisetas, vestuários, uniformes, jaqueta e trajes. Essa produção é destinada às maiores marcas dos Estados Unidos da América como GAP, Wal-Mart, Levi’s. Nesse sentido, milhões de metros quadrados de produtos são encaminhados anualmente para os EUA e uma parte para a República Dominicana e para o Canadá (MEF, 2016). Nos últimos 5 anos (2010-2015), apenas no ramo têxtil, o valor médio de exportação foi de US\$ 778 milhões. Além da montagem de peças elétricas e eletrônicas, em média, US\$ 2 milhões e filiais respondem por menos de US\$ 1 milhão por ano (MEF, 2016, p. 70).

\section{Figura 21 - Projeto do Parque Industrial Digneron}

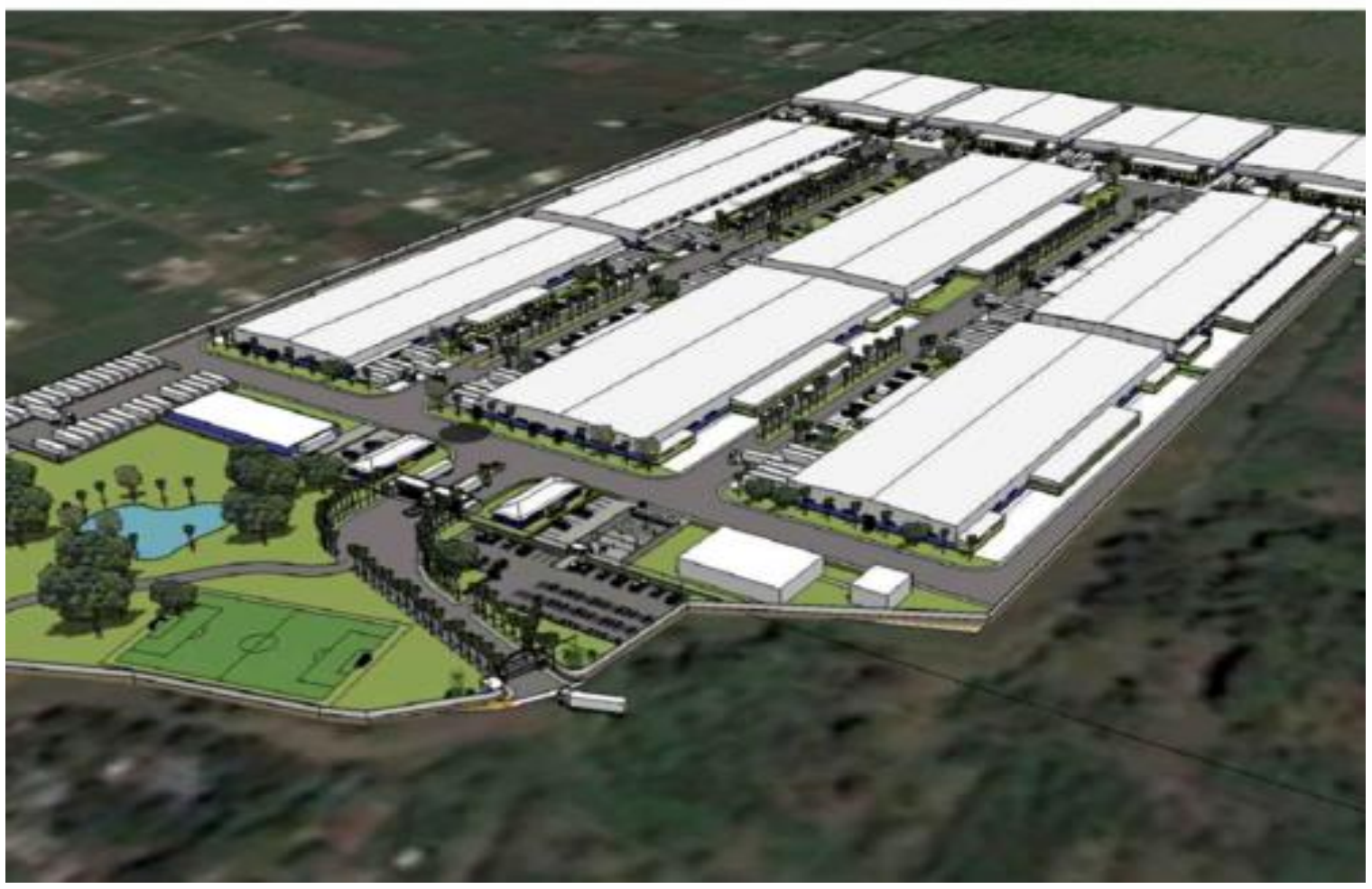

Fonte: https://www.palmapparelgroupht.com/freezones-1/ Acesso em: 20 de maio de 2019. 
A figura 21 mostra o projeto do parque industrial Palm Apparel Group Digneron, em Croix-des-Bouquets, município da região metropolitana de Porto Príncipe. Atualmente, quatro prédios industriais, dois prédios administrativos, instalações alfandegárias e infra-estrutura foram construídos. Dos 330.000 metros quadrados disponíveis, 116.000 são ocupados pela Dimax (Digneron Manufacture), que atualmente emprega mais de 1.000 pessoas, das quais $70 \%$ são mulheres, disse Roger Carrié, um dos gerentes do Palm Apparel Group. Em 2019, esse parque industrial previa gerar 15.000 novos empregos, além dos 52.000 já disponíveis no setor têxtil, segundo Georges Sassine, o presidente da Associação das Indústrias do Haiti (ADIH). Portanto, a construção de novos parques é uma estratégia para aproveitar ao máximo as vantagens competitivas oferecidas pelas leis Hope e Help, em termos de produção de produtos têxteis para exportação, principalmente, para os Estados Unidos.

Nessa dinâmica toda ligada ao liberalismo, notamos a ocorrência de uma superexploração da força de trabalho haitiana. Desta forma, não importa a situação da "classe trabalhadora" desde que os lucros aumentem, portanto a "classe capitalista do Haiti” certamente não é a única a professar esse credo, mostrando seu desprezo pela classe trabalhadora no setor têxtil. O salário mínimo atual no Haiti está entre os mais baixos do mundo, por conseguinte, mal permite a sobrevivência do trabalhador.

Como já foi mencionado, o salário mínimo no Haiti é de cerca de US\$ 200 por mês; isso não permite ao trabalhador responder às exigências do cotidiano, pois, com esse salário nenhum trabalhador haitiano, pode sair da miséria. Por conseguinte, a nossa análise sobre a situação da economia urbana ao longo desta parte da Dissertação revela que a economia haitiana está estagnada desde 1980, já que a informalidade generalizada tem tomado conta da economia urbana, revelando a desigualdade no acesso ao crédito e a sobre-exploração da mão de obra dos trabalhadores e trabalhadoras haitianos. Tudo isso, no âmbito da divisão internacional do trabalho, em que o salário mínimo é praticamente um salário de miséria numa economia em que a taxa de inflação segundo dados do Banco Central está em torno de 19\% em 2019 (BRH, 2019). Por conseguinte, essa situação só aumenta as desigualdades socioespacias na metrópole e no Haiti como o todo, fenômeno que cremos intrínseco à sua formação socioespacial, inserido na periferia dominada e explorada do capitalismo. Portanto, esse processo da formação do país é analisado e descrito no próximo capítulo desta Dissertação. 


\section{A FORMAÇÃO SOCIOESPACIAL DO HAITI}

\subsection{Sucessão e coexistência do fenômeno da desigualdade no Haiti: analise da formação do Estado haitiano}

Neste último capítulo do trabalho, apresentamos uma análise sobre o processo da formação socioespacial do Haiti do final do XVIII, ao período contemporâneo. Busca-se entender a gênese das desigualdades sociais no Haiti e as desigualdades socioespaciais em Porto Príncipe na atualidade. Partirmos da ideia de sucessão e coexistência desse fenômeno na própria formação do Estado haitiano. Tendo como referência a teoria e o método da formação socioespacial (SANTOS, 1979) como base de análise que abranja toda a problemática social no tempo e no espaço. Conforme aponta Barrios (1976, p. 20), a categoria espaço-temporal é parcialmente útil ao estudo da realidade das regiões subdesenvolvidas, pois, permite-se apreender a heterogeneidade estrutural a maneira como, em cada lugar, se articula, segundo uma lógica funcional variável ligada aos diferentes processos históricos.

Com efeito, o Haiti que conhecemos hoje, visto a partir de uma perspectiva de longa duração (BRAUDEL, 1969) ${ }^{75}$, é o resultado de vários processos inclusive como todos os países da América colonial, inseridos no processo de globalização no final do século XV. Esse processo ocorreu a partir da importância dos impactos da Revolução Científica na baliza temporal corresponde a 1500 e 1600. De acordo com Colin Ronan (1987), esse período abrange e circunscreve situações relacionadas à exploração geográfica, sofreu o impacto e o efeito da invenção da imprensa, da elaboração de mapas, do uso técnico do telescópio, bem como do manuseio da bússola. Em suma, um progresso técnico que se acelerou no final da Idade Média, especialmente, por meio do suposto progresso de invenção e de aperfeiçoamento dos navios que levaram os portugueses a uma série de viagens de exploração, seguidos pelos espanhóis, pelos ingleses e pelos franceses entre os séculos XV e XVIII.

\footnotetext{
75 Na compreensão da situação atual da cidade de Porto Príncipe e do Haiti como um todo partimos da categoria de análise longa duração descrita e discutida por Fernand Braudel. Segundo o autor, a longa duração de fato, são durações solidárias umas com as outras: não é a duração que é tanto assim criação em termo de evolução, mas as fragmentações dessa duração. Ora, cremos que os fragmentos na formação socioespacial do Haiti se reúnem ao termo da nossa temática de pesquisa em questão. No sentido que na longa duração, conjuntura, evento se encaixam sem dificuldade, pois todos se medem por uma mesma escala. Do mesmo modo, participar em espírito de um desses tempos, é participar de todos. Fernand Braudel em "Histoire et sciences sociales. La longue durée". In: Écrits sur l'histoire. Paris: Flammarion, 1969. p. 76. (1ª ed. - Annales E. S. C., nº 4, octobre-décembre 1958, Débats et Combats, p. 725-753.
} 
Esses exploradores eram comerciantes, banqueiros e governantes europeus, sendo motivados pela curiosidade do humanismo renascentista, bem como pela sede do ouro e das especiarias. Eram figuras estrutura-estruturantes dos nascentes Estados nacionais, quer dizer, cinzas da ordem feudal ligadas à expansão do cristianismo enquanto cobertura ideológica que justificou e legitimou a dinâmica fundamentada, entre outros, pela expansão do saber geográfico (geopolítica) vinculado aos EstadosMaiores nas reflexões de Lacoste (1985, p. 251), que se ligada, em concomitância, à prática do poder em relação ao espaço. Assim sendo, dentro da dinâmica da globalização os europeus se dirigiam para o leste do globo durante o século XV. Eles, no limite, acharam possível encontrar o caminho para a Ásia contornando o Chifre da África. De todo modo, existem suspeitas de que houve fundamentação técnica de caminhos para aquilo que é concebido como o Novo Mundo. É nesse contexto que em 1492, os espanhóis sob a liderança de Cristóvão Colombo, colocaram os pés na América; especialmente na ilha de Guanahani, em 12 de outubro, renomeada por eles de San Salvador, e no Ayiti (nome indígena da ilha), em 5 de dezembro do mesmo ano, que foi renomeada de Hispaniola, ou seja, pequena Espanha (PIERRE, 2014).

Destarte, após um longo período de exploração de recursos naturais e de eliminação sistemática dos nativos ${ }^{76}$, os Arawaks e Tainos, a Espanha passou a traficar seres humanos, os “escravos”. Isso se iniciou no começo do século XVI a partir do continente Africano, sendo projetado, posteriormente, para as Américas e para o Caribe, notadamente para a Hispaniola. Em 1697, sob pressão entre outros de grupos "ilegais" estabelecidos na costa noroeste da Hispaniola, a Espanha, através do Tratado de Ryswick $^{77}$, concedeu a parte ocidental da ilha à França que, por sua vez, lhe renomeia de Saint-Domingue, o Haiti atual, criando um modo de produção a partir de plantation (THOMPSON, 1935) ${ }^{78}$ e a Espanha manteve para si a parte oriental, a República Dominicana atual, (DORSAINVIL, 1934), como mostra o seguinte mapa 12.

76 Os índios Arawaks e os Taïnos foram brutalmente exterminados pelos espanhóis (JAMES, 2007). 77Disponível em: http://documentsded-TraitedeRyswick(Espagne).pdf. Acesso em: 25 de ago. de 2018. $78 \mathrm{O}$ tema plantation se refere às unidades de produção ou monocultura na colônia em termo de organização do território numa economia em expansão no mundo dos séculos XVII e XVIII; ela era de certa forma, uma importante base conceitual. Mais do que a mineração de ouro e prata nas Américas (que talvez produziu muito mais riqueza), é a plantation escravista que parece marcar o nascimento de uma nova ordem baseada em novas relações sociais. Em sua famosa publicação The Plantation, Edgar Thompson (1935, pp. 12-14) afirma que a plantation se estabeleceu nas regiões tropicais porque elas “constituem a fronteira mais importante e mais acessível da comunidade mundial". Segundo o autor, é irresistível a afirmação de que o sistema de plantation foi, portanto, um artefato da expansão e do desenvolvimento europeu dirigido para o exterior. 


\section{Mapa 12 - Ilha de Hispaniola em 1750}

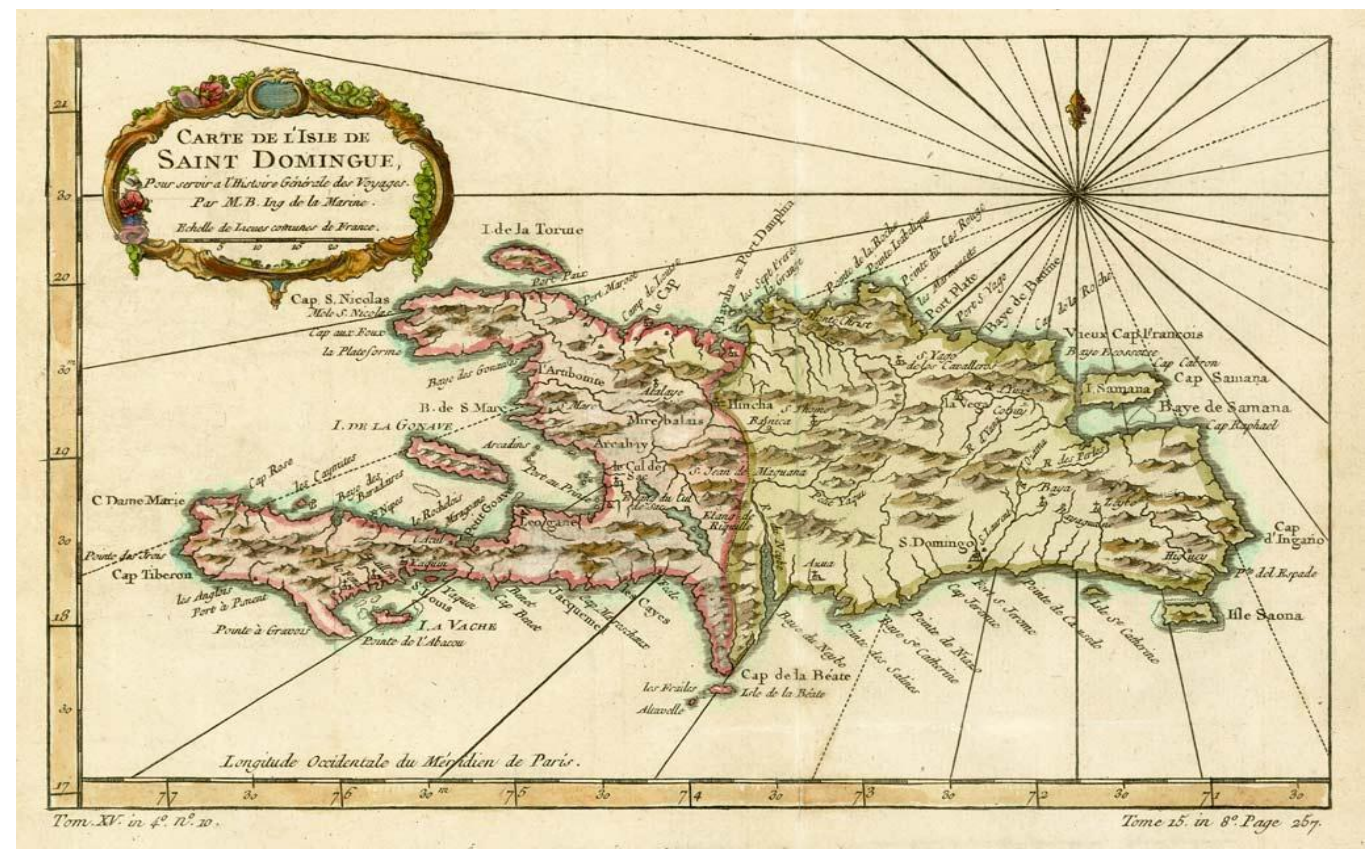

Fonte: http://www.printsellers.com/1750-bellin-dominique-p-732.html Acesso em: 20 de maio de 2018.

O mapa 12 apresenta a Hispaniola que foi dividida em duas colônias, como já vimos a partir do Tratado de Ryswrik assinado em 1697. Portanto, a partir dessa situação que a sociedade colonial escravocrata de São Domingos foi concebida sob o domínio dos colonizadores franceses, com um movimento, cabe frisar, de intensificação do tráfico de "'escravos"; como mostra Hugh (1997), em seu livro intitulado: The Slave Trade: The Story of the Atlantic Slave Trade, 1440-1870. O autor mostra como que, por meio do comércio triangular, ocorrido entre os séculos XV e XIX, o capitalismo europeu organiza o mundo entre o centro, a Europa e a periferia dominada, a África e América colonial. Portanto, a França no século XVII obteve o controle maximizado sobre a parte ocidental da ilha e lhe transformou na colônia considerada mais próspera da América no final do século XVIII por meio da exploração das suas fontes de riquezas em uma dinâmica própria à acumulação primitiva do capital (MARX, 1988) ${ }^{79}$.

79 Acumulação primitiva do capital, também conhecida como acumulação originária, foi o processo de acumulação de riquezas ocorrido na Europa entre os séculos XVI e XVIII, que possibilitou as grandes transformações econômicas da Revolução Industrial. Foi estudado e descrito por Karl Marx (1818-1883), que tomou a Inglaterra como modelo de sua teoria. A acumulação primitiva de capital segundo o autor se desenvolveu a partir de dois pressupostos: um foi a concentração de grande massa de recursos (dinheiro, ouro, prata, terras) nas mãos de um pequeno número de proprietários; outro foi a formação de um grande contingente de indivíduos despossuídos de bens e obrigados a vender sua força de trabalho aos senhores de terra e donos de manufaturas. Historicamente, isso foi possível graças às riquezas acumuladas pelos negociantes europeus com o tráfico de "escravos" africanos, com o saque colonial e a apropriação privada das terras comunais dos camponeses, com o protecionismo às manufaturas nacionais e com o confisco e venda a baixo preço das terras da Igreja por governos revolucionários. Com o advento da Revolução Industrial, conclui Marx, a acumulação primitiva foi substituída pela acumulação capitalista. 


\section{Mapa 13 - Rotas comerciais e o comércio triangular no século XVI e XVIII}

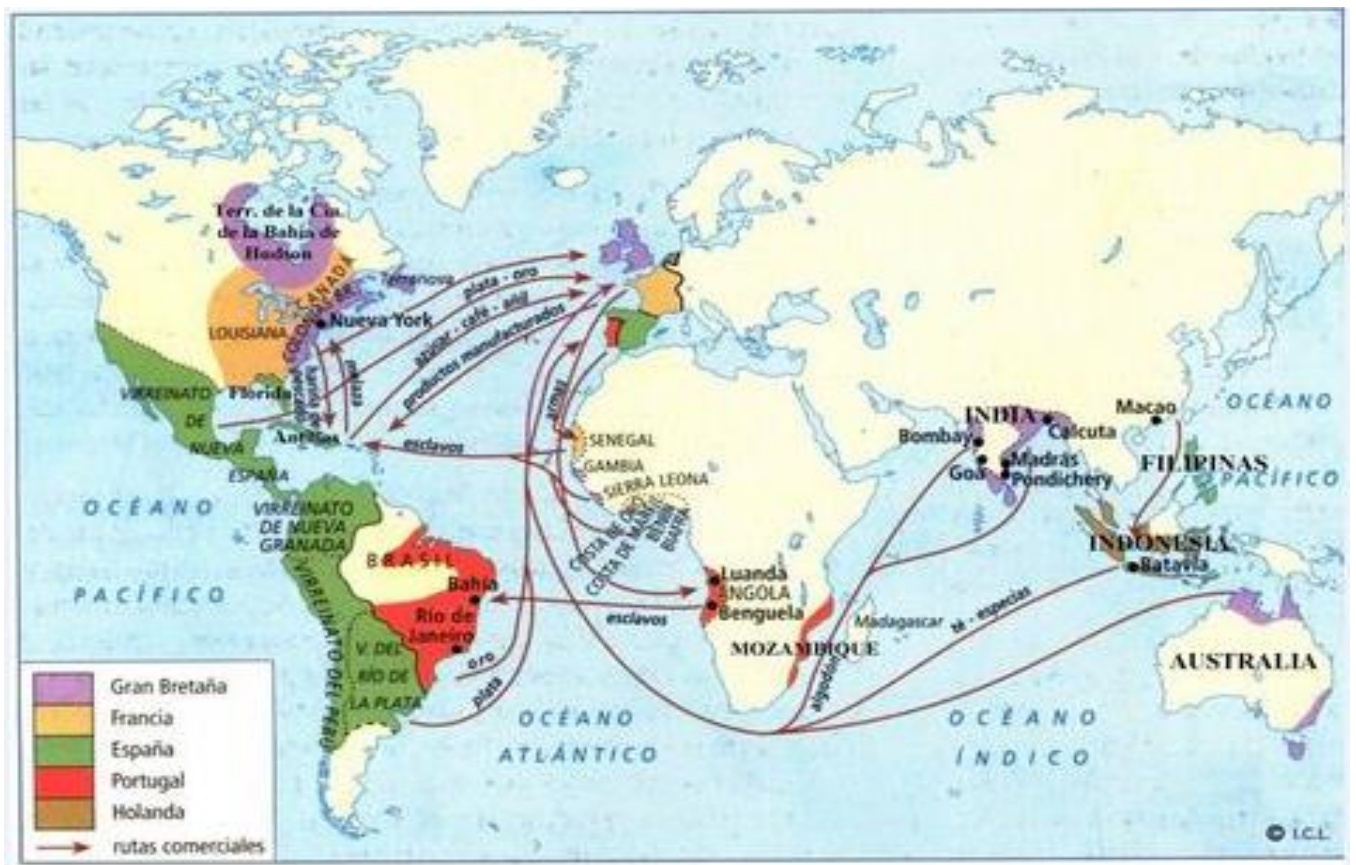

Fonte: AMILTON, 1983. Disponível em: https://br.pinterest.com/pin/631700285207635972 Acesso e adaptado pelo autor em: 5 de jun. de 2019.

O mapa 13 mostra como ocorreu o comércio triangular no Atlântico entre os séculos XVI e XVIII, considerado por Braudel (1996), como motor do sistema economia-mundo que envolve um fragmento da economia mundial. Com efeito, o comércio triangular funcionava da seguinte maneira: os navios europeus são carregados de mercadorias (roupas, armas e álcool) e deixam os portos da Europa Ocidental a caminho da costa da África Ocidental; depois os portugueses, espanhóis, franceses, ingleses e holandeses passaram a comercializar e traficar seres humanos, os "escravos". Ou seja, foram mercadorias ou foram obrigados ao trabalho e degradação por via da força. Além do mais, foram cruelmente, em um sistema "legítimo" à época, afastados e arrancados dos seus lugares de origens. Em seguida, a dinâmica colonizadora atravessava o Atlântico em direção às Américas, onde os africanos foram vendidos e escravizados em áreas coloniais. Finalmente, os navios foram carregados de produtos coloniais (ouro, prata, açúcar, tabaco, cacau, café), e regressaram à Europa Ocidental para serem comercializados no mercado europeu. Os portos da costa atlântica europeia, mas, sobretudo, o de Marselha conhecia certo boom econômico no século XVIII, graças a essa forma específica de comércio.

Segundo Michel Hector (1990), foi nesse contexto de boom econômico e de contradições sociais entre grupos que atuavam no trabalho livre pelo controle das atividades econômicas da força de trabalho escravo, que era uma forma de desigualdade 
perante o trabalho. Os sujeitos colocados em situação de escravidão alimentavam e recriaram as relações sociais de trabalho ali estabelecidas. Essa conjuntura políticaeconômica-social-cultural "deteriorou" na colônia, a tal ponto no final do século XVIII, de um lado, observou-se que o clima político em São Domingos, atual Haiti, se apresentou verdadeiramente explosivo, resultado do ressentimento mútuo e do ódio acumulados por mais três séculos, em que cada grupo social tentava, de algum modo, apresentar as suas próprias reivindicações; tanto em França quanto na colônia.

$\mathrm{Na}$ França, em 1789, a monarquia absoluta e as estruturas socioeconômicas resultantes do feudalismo estavam em contradição com a ascensão da burguesia. Desse modo, para as classes trabalhadoras, a crise econômica que estava presente há anos se reflete no aumento dos preços, do desemprego e da questão fundiária. Além disso, o Estado estava enfrentando uma grave crise financeira. Os conflitos sociais nas cidades e no campo foram aumentando, ao mesmo tempo, a burguesia esperava reformas, constituição, direitos iguais; liberdades individuais e políticas (ALEXANDRE, 1993). Basicamente, nessa direção, a burguesia francesa quis sacudir o jugo feudal para alcançar a liberdade econômica total. Para resolver o problema financeiro, os Estados Gerais foram convocados em 5 de maio de 1789. Por conseguinte, os eventos que se seguiram permitiram que a burguesia ganhasse poder político e levasse à mobilização da classe trabalhadora, levando a uma radicalização do processo revolucionário.

Na colônia de São Domingos, atual Haiti, por sua vez, circulavam as ideias da Revolução Francesa emergindo, pois, demandas que apontavam para uma valorização de sentimento de rebelião; não sendo a colônia uma simples extensão territorial da França. A colônia, arrematando a argumentação, tinha as suas dinâmicas próprias em termos de contradições entre grupos que compõem a sua pirâmide social (JEAN PIERRE, 1985). Por conseguinte, e a partir daí uma série de movimentos de revolta em São Domingos foram conduzidos pelos escravizados e descendentes de escravizados que pegaram em armas com o objetivo de destruir e transformar revolucionariamente a estrutura social da sociedade escravocrata de economia de plantation estabelecida pela França na parte ocidental da ilha. Essa movimentação político-social foi o esteio para a emergência de uma Revolução anticolonialista, antiescravagista e antirracista dentro do processo da formação socioespacial do Haiti.

Segundo Dorsainvil (1934), o ano de 1791 foi decisivo nesse processo, pois ele sintetiza a configuração do ritmo de decomposição da colônia diante dos problemas enfrentados pelos diferentes grupos sociais proprietários de bens que mantiveram o 
sistema colonial enquanto uma espécie de arcaísmo como projeto ${ }^{80}$, bem como os escravizados em busca da sua liberdade. Nessa direção, os haitianos que foram escravizados anunciaram e prefiguraram uma Revolução radical em seus horizontes. Portanto, o destino da colônia definiu-se face às desigualdades do trabalho livre e trabalho servil, que criam condições para uma situação explosiva. Dito de maneira diferente: esses sujeitos praticaram, nos mais variados eixos sociais, formas de resistência, havendo, inclusive estratégias extremamente radicais, tais como: suicídios, homicídios, conspirações contra os colonizadores e o marronnage ${ }^{81}$ (DORSAINVIL, 1934).

Há um caso significativo de resistência haitiana que achamos conveniente explorar, qual seja, a Cerimônia du Bois Caiman $^{82}$, ocorrida em 14 de agosto de 1791 sob a liderança de Boukman Dutty, que tem papel decisivo, a nosso ver, enquanto exemplo concreto do que Marx e Engels (2005) denominam em A Ideologia Alemã como a passagem de uma "consciência de si" para uma "consciência para si". Logo após essa Cerimônia o movimento de resistência antiescravista cria condições, como uma espécie de estopim, para uma revolta de natureza geral. Em 22 de agosto do mesmo ano ela se concretiza, tendo por objetivo a destruição da estrutura social da sociedade escravocrata (JAMES, 2007). Em resumo: demanda-se a transformação da realidade do ser social escravizado para um ser social livre de opressão e de desigualdade parente ao trabalho. No entanto, esse evento não consta e não é destacado, nas obras desses dois pensadores, criadores de discursividade do século XIX.

80 Articulamos a ideia do arcaísmo como projeto dentro da dinâmica colonial em São Domingos, atual Haiti, baseados em Florentino, Manolo. O arcaísmo como projeto: mercado atlântico, sociedade agrária e elite mercantil em uma economia colonial tardia, Rio de janeiro, c.1790- c.1840. Rio de Janeiro, 2001.

81 Marronnage: o movimento de resistência antiescravista, equivalente ao dos quilombolas no Brasil.

82 Esta cerimônia religiosa do "vaudou" ou congresso político (PIERRE, 2014) foi a plataforma espiritual sobre a qual foi potencializada toda revolta, foi antes de tudo uma cerimônia de aliança entre homens e mulheres recusando a escravidão, e a superação da contradição de língua entre eles para unificar seu movimento de revolta, uma aliança contra o estupefato do homem pelo homem, a aliança entre escravizados de diferentes culturas e tradições, aliança entre a terra de São Domingos [Haiti] e os deuses africanos, aliança entre homem negro humilhado e a sabedoria espiritual africana, a aliança entre as energias físicas e místicas do africano encadeado, a aliança entre o escravizado negro e o mulato, a aliança entre o sofrimento dos negros e as lembranças dos Arawaks e Tainos, os primeiros habitantes da ilha; aliança entre o interesse particular para o bem-estar coletivo. Esta aliança, este pacote ideal que tinha um alcance universal de liberdade, incitava os "escravos" a transformar suas práticas individuais como: desobediência, suicídio, complot, incêndio de plantations, aborto ou envenenamento em um vasto movimento de revolta, precursor da independência haitiana. Este movimento popular sem precedentes, que reuniu todos os "escravos" da colônia, inaugurou uma nova era que deixou atrás a escuridão da escravidão, iluminando assim, o caminho pela formação de um novo Estado independente e soberano. 
No entanto, o processo da transformação da sociedade escravocrata de São Domingos, atual Haiti, para uma sociedade livre baseada em outros tipos de relações de trabalho a partir 1804, é conduzido por escravizados ou por seus descendentes negros. Desta forma, o "escravo" como ser social pensante tem consciência da sua realidade social como tal; e recusa de ser considerado como escravo e de mercadoria coisificada que se vende e que se compra no circuito da dinâmica colonial para se tornar cidadão. Dito isso, transformando a "consciência de si" para uma "consciência para si", que se concretiza durante e após a Cerimônia político-espiritual du Bois Caiman em 1791. Esse evento $^{83}$ (SANTOS, 1996), isto é, a entrada oficial dos haitianos escravizados no cenário político na colônia impulsionou e prefigurou a Revolução Haitiana que, do ponto de vista social, culminou com a abolição da escravidão, proclamada em 29 de agosto de 1793 e ratificada pela França em 4 de fevereiro de 1794, sob a liderança de Toussaint L'Ouverture (JAMES, 2007).

Em 1799, após um golpe (o golpe de Estado do 18 Brumário), o general Napoleão Bonaparte tornou-se chefe de Estado da França e estabeleceu um regime totalitário, o conhecido Consulat (DORSAINVIL, 1934, p. 129). Objetivava-se, nesse cenário, a manutenção do sistema colonialista e escravagista. Nesse sentido, e para refratar a marcha ascendente rumo à independência da colônia, o líder francês enviou uma considerável expedição militar, contando com 22 mil homens, à São Domingos, atual Haiti (DORSAINVIL, 1934, p. 128, HECTOR, 1990). Essa expedição foi composta por soldados veteranos de guerra sob o comando dos melhores oficiais que participam da expedição militar de Bonaparte no Egito (1798-1799).

Para dar maior importância a essa operação intervencionista-militar a expedição, tamanho o seu significado geopolítico, foi comandada por seu cunhado, o General Leclerc. Em síntese, e dando credibilidade aos nossos argumentos: 'um exército que era composto de um número gigantesco de soldados de grande talento, bons estrategistas, grandes táticos, oficiais de engenharia e de artilharia, bem instruídos e cheios de recursos (PANPHILE, 1819, v. 2 p. 319 apud JAMES, 2007, p. 252) ". Tudo isso com o objetivo de deportar os principais líderes dos revoltosos para a França como foi o caso de Toussaint Louverture que foi preso, em seguida deportado para

83 Com base em Santos (1996), o evento aqui teria um sentido histórico. É o vetor das possibilidades existentes numa formação socioespacial, isto é, num país ou numa região, ou num lugar, considerado esse país, essa região, esse lugar como um conjunto circunscrito e mais limitado que o mundo. 
França e, morto lá, em 7 de abril de 1803, de demitir as tropas coloniais e desarmar os escravizados. Por fim, reestabelecer e atualizar a ordem e, o projeto colonialista, isto é, o restabelecimento e a atualização da escravidão na colônia; evidentemente devido à importância econômica dessa para a manutenção da sociedade escravocrata em São Domingos, atual Haiti (DORSAINVIL, 1934, p. 139). Todavia, desembarcando na colônia em fevereiro de 1802, os franceses encontraram formas de resistência proporcionais; até porque foram várias batalhas e enfrentamentos entre o exército metropolitano e as forças armadas nacionais comandadas por ex-escravizados ou descendentes de escravizados (DORSAINVIL, 1934). Portanto, a última é a Batalha de Verttières, ocorrida em 18 de novembro de 1803, em que definitivamente ocorreu a vitória do exército da libertação nacional, liderada pelo General Jean Jacques Dessalines que pertencia à linha-dura da Revolução Haitiana (DORSAINVIL, 1934, p. 161).

Por conseguinte, as forças de extermínio colonialista, escravista e racista francesas foram superadas, resultando, no dia $1^{\circ}$ de janeiro de 1804 , na Proclamação da Independência do Haiti. Nessa direção, acreditamos que a abolição da escravidão seguida da independência são as primeiras formas de experiência ${ }^{84}$, no sentido dado por Thompson (1987) de luta contra eixos morais e normativos advindos do projeto colonialista e escravista, levantando bandeiras do respeito da dignidade humana e de um agir moral que alcança os direitos fundamentais dos seres humanos de forma avant la lettre. Isso porque é a única revolta bem-sucedida conduzida por escravizados ou descendentes de escravizados na história da humanidade, resultando na formação de um Estado e que é mantido, de alguma forma, independente, livre e soberano até hoje.

Na ocasião desse evento, em 1804, Jean Jacques Dessalines, o General-chefe do exército de libertação nacional dirigiu-se ao povo haitiano relatando as atrocidades do regime escravocrata e as lembranças das crueldades dos opressores franceses. Dessalines, nessa situação específica, chama a atenção para os males do colonialismo em todas as suas formas e moldes. Ele fala de como o circuito de vida, do nascimento ao crescimento de um sujeito dentro do sistema da escravidão, é afetado por essa dinâmica e formas de exercício do poder; em que crianças, adolescentes, jovens, mulheres, esposas, maridos, irmãos, primos, irmãs, primas negros tornaram-se alienados e sem o reconhecimento da sua própria persona subjetivada. 
Nesse sentido, por esse discurso, ele oferece a verdadeira dimensão universal aos Diretos Humanos que antes foram reservados, por brancos atuando no trabalho livre no capitalismo comercial tanto na França como nas suas colônias, em que os negros foram considerados juridicamente por meio do Código $\mathrm{Negro}^{85}$, como escravos e mercadoria coisificada por esses mesmos sujeitos europeus. Reforçando o nosso argumento, a Declaração dos Direitos do Homem e do Cidadão promulgado na França, em1789 estipula em seu art. $1^{\circ}$ que "os homens nascem e permanecem livres e iguais em direitos $[\ldots]$ '. . Para mostrar aos europeus que esses princípios valem para todos os homens no contexto específico de tomada de pose como chef do novo Estado do Haiti Dessalines, em um ato de honra patriótica, distanciou-se radicalmente dos colonialistas franceses preferindo morrer ao invés de viver sob a sua dominação. Nisso cria-se o mito de fundação que consagra a independência da colônia Saint-Domingue, tornando mártir a figura de Dessalines. Ainda falando de mitos de fundação, recupera-se o antigo nome indígena da ilha, qual seja, Ayiti ${ }^{86}$ (JEAN PIERRE, 1985).

Portanto, do ponto de vista jurídico-político, essa Proclamação da Independência da colônia marca transformações substanciais na forma do governo instaurado pelo regime escravocrata. A data específica desse evento é $1^{\circ}$ de janeiro de 1804 que, ao mesmo tempo, significa a fundação de uma nova sociedade na qual os haitianos adquirem o direito de estabelecer seu próprio governo livre, independente e soberano no meio desse processo formativo do Estado haitiano visando, outros tipos de relações sociais de trabalho. Então, para evitar que a Revolução Haitiana sirva de modelo para as outras colônias nas Américas, o Haiti foi cercado por um "muro de silêncio" que encoberta a sua luta anticolonialista e antiescravagista. Nesse movimento os seus princípios universais são ideologicamente adulterados, posto que se quer fazer da Revolução Haitiana uma revolução local, ou uma revolta sem consciência de classe e apoio em experiências sociais partilhadas. No entanto, nesses jogos diplomáticos e geopolíticos, o Haiti apresentou-se muito generoso ao oferecer, em 1816, proteção e apoio a Simon Bolívar (considerado liderança progressista da Venezuela) na sua guerra

85 O Código Negro publicado na França, em 1685, regulamenta a economia, o comércio, o governo e administração nas colônias francesas da América. Esse código trata o ser humano, ou seja, o escravo, enquanto propriedade de seu dono. Ele foi aplicado em São Domingos, atual Haiti oficialmente até $1^{\circ}$ de janeiro de 1804 e está disponível em: http://guygiard.artbabyart.net/HTMLobj-511/codenoirtxt.pdf Acesso em: 22 de jun. de 2019.

86 O Ayiti (Haiti, na língua francesa), significa terra montanhosa ou grande terra na língua indígena dos Arawaks e dos Tainos disseminados pelos espanhóis na primeira metade do século XVI. 
de Independência contra a Espanha. Ou seja, a Revolução Haitiana ilumina e serve de magistra vitae no sentido de encontrar o caminho para a libertação total de todas as colônias da América Latina que estavam sob o jugo da colonização e da escravidão; tornando, assim, símbolo de resistência de todos os povos oprimidos e explorados pelo/na história do capitalismo. O mapa 5 mostra o processo de proclamação de independência dos países na América Latina e do Caribe.

\section{Mapa 14 - Independências dos países da América Latina e do Caribe}

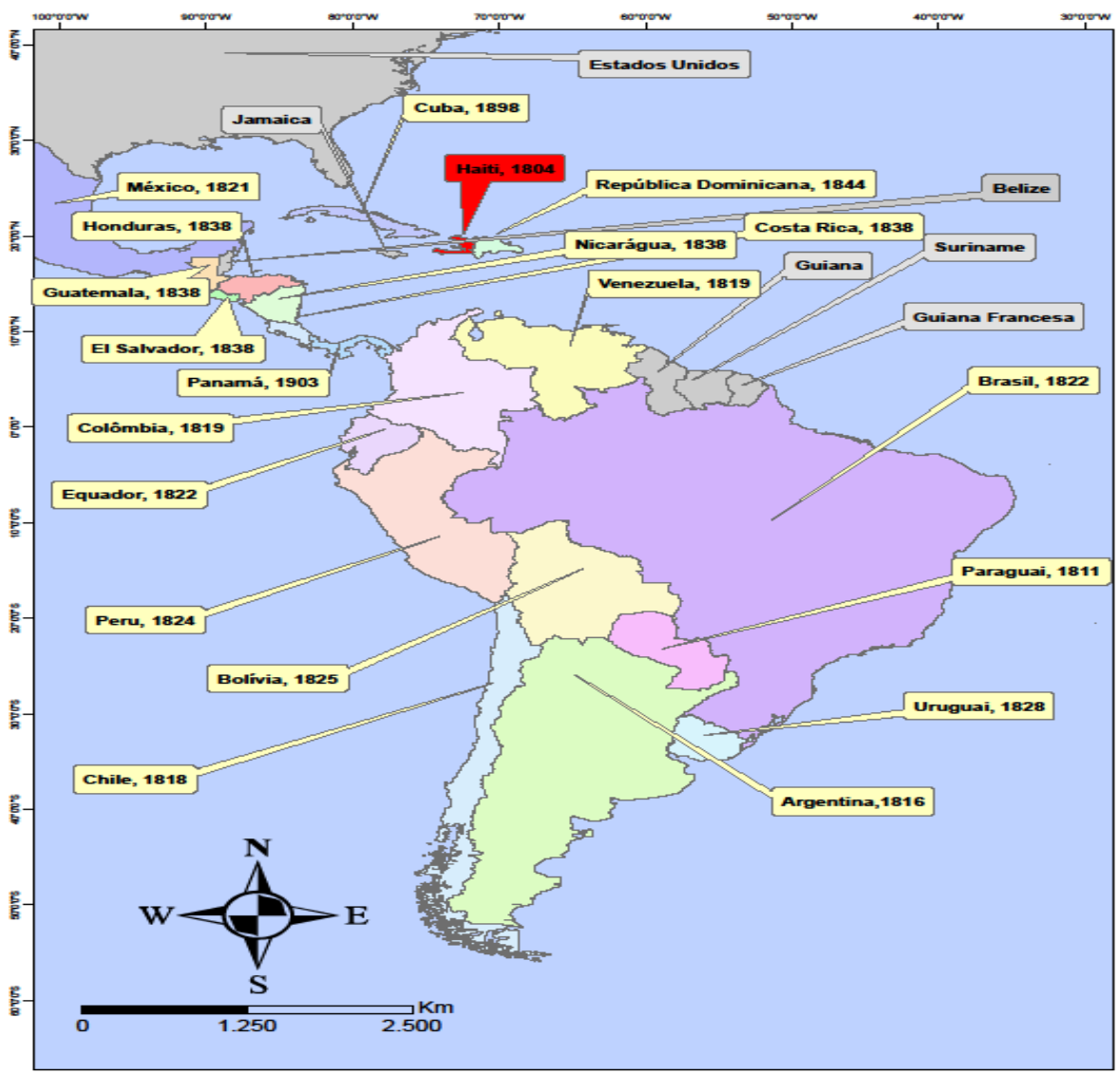

Fonte: IBGE, 2018. Organização das informações: Ismane Desrosiers. Elaboração cartográfica: Thiago Esteves Nogueira, 2018.

O mapa 14 apresenta o processo de Independência dos países da América Latina e do Caribe e a situação geopolítica do Haiti no início do século XIX como um Estado independente e soberano em relação aos territórios vizinhos colônias das potências colonialistas europeias como Espanha, França, Inglaterra. Mesmo os Estados Unidos da América que é independente desde 1776 mantem o sistema da escravidão. Diante da importância dessa prática como motor da economia-mundo (BRAUDEL, 1996) na época do capitalismo comercial pode-se dizer que a Revolução Haitiana de 1804 é vitoriosa em sua campanha moral e ética. Ademais, em termos de posicionamento Sul dominado constitui-se, de alguma forma, o fundamento do chamado pensamento 
decolonial $^{87}$ junto à produção intelectual de pensadores haitianos do século XIX como, por exemplo, Lous-Joseph Janvier (1855-1911) e Antenor Firmim (1850-1911). É a vitória dos princípios de liberdade, de autonomia e de independência contra o colonialismo, o escravagismo e o racismo; sendo, por outro lado, a vitória de um país pequeno pela sua dimensão territorial, mas portador de uma população combativa em razão da sua história singular de luta contra uma das maiores potências coloniais, a França, por intermédio de uma consciência de classe, entendida como congregação sociocoletiva de experiência (escravidão). E, recorrendo aos seus mitos de fundação e de constituição de uma comunidade imaginada ${ }^{88}$ (BENECDIT, 1991) que se vê combativa e assertiva em termos experienciais diante dos considerados invencíveis colonialistas, com as suas grandes frotas equipadas, com seu exército de infantaria invulnerável e, sobretudo, por estarem equipados ideologicamente por meio do seu arcaísmo como projeto civilizador-colonialista-excludente-genocida.

Nesse sentido, o ano de 1804 marca a primeira grande derrota europeia na América em termos materiais, políticos e, sobretudo, simbólico-ideológicos. Montesquieu (2000, p. 257), em $O$ espírito das leis afirma que "os escravos são negros desde os pés até a cabeça e tem nariz tão achatado que é quase impossível deles ter pena. Tornar-se impossível que Deus, que é um ser muito sábio, tenha posto uma alma, principalmente, uma alma boa num corpo inteiramente negro". Para mostrar o contrário a esse discurso racista e de ódio do filósofo francês, o haitiano evidencia que o negro tem uma alma boa, na medida em que se faz presente por meio da sua contribuição sociopolítica junto à história global da emancipação do Homem Negro e a Mulher Negra; enfatizando, de formas variadas, os seus direitos políticos, socioeconômicos e culturais perante a sociedade contemporânea. Mas, por seus métodos radicais e pouco usuais de luta pelo respeito da dignidade humana, sobretudo do "homem negro" e da "mulher negra", cremos que o exemplo haitiano entra em um processo de esquecimento ou de esmaecimento no continente devido ao conjunto de símbolos formadores de discursividade que ele, enquanto exempla, abalou as relações de poder prefiguradas e estabelecidas. Assim, o Haiti incomodou os interesses da burguesia agrária e comercial

87 Corrente de pensamento de oposição ao sistema colonial, contra a expansão europeia s que se iniciou, em 1492, na América. Essa linguagem teórica e epistemológica conta com contribuições de autores como Janvier (1882), Firmin (1885), Quijano (1981, 1977, 1988), Fanon (1983), Davis (2016).

88 Segundo Anderson Benecdito, uma comunidade imaginada é aquela que evoluiria para se tornar uma nação. Essa categoria de análise é descrita no seu livro Imagined Communities: Reflections on the Origins and Spread of Nationalism. Revised ed. London: Verso, 1991. 
da França e a do Ocidente como um todo, por razões econômicas, geopolíticas, ideológicas e simbólicas enquanto agenciamento da realidade daquela época.

Por conseguinte, após a ruptura com a França, suas práticas colonizadoras e simbólico-ideológicas, o jovem Estado haitiano como o mau exemplo a ser repreendido enfrentou as hostilidades diplomáticas, comerciais e geopolíticas das potências colonialistas e escravagistas da Europa Ocidental e dos Estados Unidos até pelo menos a segunda metade do século XIX. Nessa direção, elas se impõem ao país um triplo bloqueio: político, diplomático e comercial recusando a independência do Haiti. Fazendo com que o Estado haitiano, nesse sentido, mantenha relações comerciais informais com os mesmos no que refere a trocas a seu favor, sobretudo, os EUA nas palavras de Trouillot (1990).

Com efeito, entre os países que não aceitaram durante mais de meio século a reconhecer a independência do Haiti encontramos, principalmente, os seguintes centros metropolitanos: a França, os Estados Unidos da América e o Vaticano. O Haiti proclamou a sua independência em $1^{\circ}$ de janeiro de 1804 , de uma forma solitária, porque nenhum tratado e nenhum armistício foi assinado legitimando a ação haitiana, ou seja, nenhum país reconheceu a sua independência. Pelo contrário, o país permaneceu aos olhos do mundo dominante (escravocrata) uma colônia rebelde, que é uma forma de deslegitimação da ação e da atuação daqueles sujeitos. Para ser aceito no cenário internacional, em termos diplomáticos, comerciais e geopolíticos, foi preciso primeiro ter a sua independência reconhecida pela antiga metrópole, a França.

Este foi o significado das ações do presidente do Haiti, Jean Pierre Boyer, filho de um colonizador francês e de mãe haitiana que iniciou em 1821, a demanda de reconhecimento do jovem país. Boyer conduz à ordem do Rei Charles X da França em 1825. Somente a partir dessa sinalização diplomática e geopolítica a França passou a reconhecer a independência do Haiti. Para isso, se demanda à nação haitiana a redução de metade dos direitos aduaneiros para os navios franceses em seus portos, bem como exige o pagamento de uma indenização de 150 milhões de franco-ouro; renegociadas treze anos mais tarde, em 1838, para o valor de 90 milhões (WARGNY, 2004, p 54) de “indenização" por suas perdas durante a Revolução Haitiana. Ou seja, perdas do contingente de soldados, de terras, de meios de produção e do montante de homens escravizados. A independência conquistada teve que redimir-se, o que não deixa de ser uma grande ironia! O valor da indenização foi combinado para ser pago até 1886 que na verdade foi pago até 1952. Nesse sentido, a nosso ver, o século XIX para o Haiti é um 
século perdido, pois, de acordo com Wargny (2004) o valor da indenização segue um cálculo que totaliza mais de US\$ 21 bilhões, em 2003. No governo de Jean Bertrand Aristide (2001-2004), foi solicitada em vão à França essa indenização ao Haiti às vésperas do bicentenário da independência do país, em 2004 (WARGNY, 2004, p. 59). Segundo Benoit Joachim (1979), o pagamento da indemnização à França pode ser considerado um elemento do fracasso, em termos de desenvolvimento, e um equívoco diplomático e geopolítico por parte do Estado haitiano. O autor afirma que:

O pagamento da indenização à metrópole afeta o projeto de desenvolvimento do país sobre várias gerações o que faz com que o país fique em um círculo vicioso de dívida, de empobrecimento, autoritarismo e a dependência crescente de potências capitalistas, incluindo a França e os Estados Unidos (JOACHIM, 1979, p. 83).

Contudo, o objetivo de conseguir o reconhecimento da independência do país foi de habilitar a desenvolver relações comerciais e diplomáticas em pé de igualdade com as potências europeias e os Estados Unidos. Para nós, haitianos, e aqui seque um testemunho local, é provavelmente o aspecto mais importante que leva o presidente do Haiti, Jean Pierre Boyer (1818-1844), a aceitar os termos solicitados da indenização da França visando um futuro iluminado para o país, ou seja, sem ostracismo, sem isolamento político, diplomático, comercial e educacional que cintila aos olhos do governo haitiano. Além disso, o presidente acreditou que o Haiti pode pagar a compensação, pois o país era um grande produtor de café, de açúcar, de cacau, entre outros produtos agrícolas (PIERRE, 2014). Segundo Trouillot (1990), os Estados Unidos da América mantem o isolamento oficial e forçado do Haiti por uma escolha econômica e estratégica, posto almeja a obtenção de benefícios de trocas informais com o jovem Estado haitiano, dentro dos horizontes da Doutrina Monroe ${ }^{89}$. Dito isso em 1822, os Estados Unidos reconheciam formalmente a independência de todos os países da América Latina que se libertam da tutela espanhola e portuguesa (Brasil); apesar de ambos, oficialmente, em seu respectivo ato de independência (o dos Estados Unidos de 4 de julho de 1776 e o do Haiti de $1^{\circ}$ de janeiro de 1804) proclamam a liberdade e a igualdade para todos contra o status quo das antigas metrópoles europeias.

89 Doutrina Monroe é o princípio que afeta os direitos e interesses dos Estados Unidos, que o continente americano, em virtude da condição livre e independente não pode mais ser considerado, no futuro, como suscetíveis de colonização por nenhuma potência europeia [...] (Mensagem do Presidente James Monroe ao Congresso dos EUA, 1823). A sentença desse projeto geopolítico pode ser resumida também numa frase: a "América aos Americanos". Mais informações disponíveis em: http://www.historia.seed.pr.gov.br/arquivos/File/fontes\%20historicas/doutrina_monroe.pdf. 
Nesse sentido, enquanto os governos norte-americanos adotaram uma política de ostracismo em relação ao Haiti, os seus comerciantes se beneficiam enormemente do comércio desigual e informal com o país. O fato é que a proximidade geográfica do Haiti com os Estados Unidos lhe tornou uma espécie de "quintal" para a venda de seus produtos. Por exemplo, segundo Trouillot (1990, p. 87), na virada do ano de $182145 \%$ das importações do Haiti foram provenientes dos Estados Unidos. Além disso, mesmo após o reconhecimento da independência do Haiti pela França, em 1825, o jovem país esperou até 1862, ou seja, três anos antes da abolição oficial da escravidão nos Estados Unidos, ocorrida após a Guerra de Secessão de 1865.

Além dos Estados Unidos da América, o segundo Estado independente da América foi isolado pelas autoridades da Igreja Católica do Vaticano, cuja negação de reconhecimento tem forte impacto no Haiti. Apesar dos reiterados pedidos dos primeiros líderes haitianos, o Vaticano se recusou, por mais de cinquenta anos, a reconhecer a independência do país; criando um efeito diplomático considerável, por exemplo, a nível educacional. De fato, como aponta Trouillot (1990), na Europa católica as ordens religiosas constituem-se a base de um sistema de educação formal. Saindo da escravidão, e com a maioria da população analfabeta, o Haiti necessitava desesperadamente de ajuda de missionários cristãos cuja reputação no campo da educação era notória. Saint-Domingue, atual Haiti durante três séculos de colonização nunca conhecia um sistema educacional formal, sendo que apenas um pequeno número de filhos de brancos nascidos na colônia, e ainda poucos negros, entre os mais ricos, foram educados na França (TROUILLOT, 1990). Nessas condições, o reconhecimento da independência pelas autoridades da Igreja Católica do Vaticano permitia que o Haiti se beneficiasse a longa tradição de savoir-faire da Igreja, bem como o conhecimento dos missionários em vista de estabelecer um sistema educacional público e aberto a todos no país. Mas, por que a Igreja Católica demorou mais de 50 anos para reconhecer a independência do Haiti? Será que as autoridades morais da Igreja Católica foram a favor da escravidão? Capítulo trágico da nossa história ocidental de tipo capitalista e de fundo cristão moralizante. Com efeito, o Haiti esperou até 1860 para que a Igreja Católica reconhecesse formalmente a sua independência. Ao mesmo tempo assina o Concordat ${ }^{90}$ (um acordo) para criação de escolas (chamadas de escolas "congressistas"

90 Disponível em: https://www.haiti-reference.com/plan/religions/eglise catholique/concordats/concordat-de-1860/. Acesso em: 18 de abr. de 2018. 
ligadas à Igreja Católica), respondendo, portanto, às necessidades de uma educação formal. Enquanto isso as classes dominantes urbanas dirigem esse sistema educacional para atender as suas próprias necessidades (TROUILLOT, 1990, p. 51). Isso, a nosso ver, cria, assim, a desigualdade em termos de acesso à educação formal no que diz respeito ao contingente populacional que habitava o meio rural. Nesse sentido, os líderes haitianos entendem que a independência, em um mundo colonial, escravocrata e racista, não se faz possível de forma plena diante desses arranjos geopolíticos. Eles procuraram obtê-la frente às potências metropolitanas através de negociações (a indenização), lobbies, ofertas de vantagens comerciais. Ou seja, diante do vício de solidariedade internacional entre potências colonialistas e escravagistas a única opção era entrar em negociações com a antiga metrópole para chegar a um compromisso sobre o reconhecimento do país como um Estado de direito próprio. Nessa direção, cremos que o Haiti é o primeiro "laboratório" de experimentação de sanções diplomáticas e econômicas das grandes potências ocidentais. Portanto, esses instrumentos são muito eficazes até atualidade para arruinar a economia e o projeto de desenvolvimento de um país inteiro que não aceita a hegemonia dessas potências, por exemplo, os EUA versus a Venezuela.

As potências ocidentais do século XIX tiveram esse posicionamento contra o Haiti, pois a Revolução Haitiana era percebida como um perigo, um mau exemplo para seus interesses. Considerando o Haiti como um Estado que devia confinar-se, retrair-se, ensimesmar-se, ou até mesmo asfixiar-se em termos socioeconômicos e diplomáticos, era "necessário deixá-los cozinhar em seu próprio caldo", dizia Talleyrand, Ministro dos Negócios Estrangeiros de Louis XVIII, durantes os governos de Restauration (18141830). Seus líderes escreviam aos países europeus e os Estados Unidos solicitando o não reconhecimento da independência do Haiti (MANIGAT, 2004).

Portanto, esse isolamento e o caso da indenização contribuem, isso visto em uma perspectiva de longa duração, para o subdesenvolvimento e para (re)criação das desigualdades no Haiti. Marcas profundas do passado estão em questão na atualidade. Contudo, não se trata de uma questão determinista e evolucionista, mas de uma problemática experiencial que pode fazer compreender e fazer entender certas nuances dos processos da formação socioespacial do Haiti, no passado e no período atual; na medida em que além da exploração colonial o país torna-se endividado ao longo de todo o século XIX, pagando grandes montantes financeiros que deveriam ser investidos, por exemplo, em projetos e planos nacionais de desenvolvimento do país. 


\subsection{Raízes das desigualdades sociais no Haiti}

Após a proclamação da independência do Haiti, em 1804, o país herdou uma estrutura socioeconômica geradora, se visto em longa duração, de um substancial fenômeno de desigualdade. Nesse sentido, entre os desafios enfrentados pelo jovem Estado recentemente independente se refere à organização socioeconômica e política da sociedade pós-colonial e escravocrata. Na época colonial a estrutura social-econômicapolítica de São Domingos, Haiti atual foi complexa devido à divisão da sociedade em grupos sociais caracterizadas e ilustradas pela posse ou não dos meios de produção (principalmente terra e escravizados). No topo da pirâmide social havia os grandes proprietários dos meios de produção: brancos, administradores, políticos e comerciantes. Além disso, eles possuíam as normas (SANTOS, 1996) e leis, incluindo as relacionadas ao chamado Código Negro de 1685, em que os canais comerciais, de capitais e de meios de produção foram gerados para estabelecer e para aperfeiçoar as suas riquezas (MOISE, 2009 apud PIERRE, 2014).

No pós-independência os fundadores do Haiti almejam a criação de um novo país, em termos de comunidade imaginada, para livrar-se das desigualdades herdadas do período do colonialismo e do escravagismo. Porém, a estrutura socioeconômica deixada pelos colonizadores franceses fez com que dois grupos sociais dominantes se colocaram à frente das massas dos camponeses. Apresentavam-se por meio de dois vetores: os antigos livres (da escravidão) e um emergente grupo social dominante, chamado de novos livres (da escravidão). Ambos os grupos representavam 5\% da população haitiana em 1804, de um total de 500.000 habitantes (IHSI, 1950, 1971, 1982, 2003). Os antigos livres (pessoas que não conheciam a escravidão na colônia) foram constituídos, principalmente, por mulatos nascidos na colônia de pai branco e mãe negra. Os mais ricos possuam, em 1789, um terço das terras e de escravizados. Eles se aliaram aos revoltosos em 1791, contra os absentistas ( aqueles que tinham propriedades na colônia, mas que moravam na França). Com a eliminação e a expulsão desses últimos durante a Revolução Haitiana (1791-1804), a fortuna na forma de propriedade da terra dos antigos livres foi reforçada. Além disso, eles também dominavam o setor de comércio, possuíam riquezas e competência em termos de conhecimento, pois eles se formavam na Europa e ocupavam alto cargo no aparelho estatal estruturado na colônia. O novo grupo dominante forma a segunda categoria social composta, principalmente, por exsoldados, oficiais negros e veteranos da guerra da libertação nacional. 
O terceiro grupo na estrutura da sociedade haitiana, os camponeses que possuam somente a sua força de trabalho, sem terras, permaneciam nas plantations em condições análogas à da escravidão e representava quase $95 \%$ da população. Dessa forma, as terras confiscadas dos colonizadores franceses sofriam um processo de nacionalização. Isso é previsto na Constituição Imperial ${ }^{91}$, de 1805 , do governo de Jean Jacques Dessalines (1804-1806), que estipula, no seu art $12^{\circ}$, a transferência jurídica do patrimônio nacional dos bens dos colonizadores proclamando o seguinte: “Qualquer propriedade que tenha pertencido anteriormente a um branco francês é incontestável e legalmente confiscada em beneficio do Estado". Jean Jacques Dessalines, ex-escravizado e primeiro chefe de Estado do Haiti, expressava sua vontade de redistribuir as terras à massa dos camponeses. Diz ele: “Cuidado com vocês, negros e mulatos, todos vocês lutaram contra os brancos, os bens que todos nós adquirimos por derramar nosso sangue nos pertencem, quero que eles sejam compartilhados com a equidade (DESSALINES, 1758-1806) ". Pode-se considerar Jean Jacques Dessalines um percussor do socialismo, ao menos à nível de ethos, na América?

Portanto, no âmbito da distribuição dos bens expropriados dos colonizadores franceses foi empreendida uma série de medidas de verificação de títulos de propriedades privada da terra; que a meu ver é um ato decisivo na lógica de uma reforma agrária sob o governo daquele que se revoltava constantemente contra a desigualdade que reinava em São Domingos no período colonial e escravocrata. No seu discurso de tomada de posse, em $1^{\circ}$ de janeiro de 1804, nele fez o seguinte questionamento: " E os Negros, cujos os pais estão na África, eles não terão nada? Nesse sentido, em 24 de julho de 1804, Dessalines ordenou uma verificação geral dos títulos de propriedades privada da terra, tentando uma reformulação da ordem estabelecida, determinando, assim, quem foram os verdadeiros donos das terras. Como resultado, essas medidas atraíram muitos inimigos oriundos dos dois primeiros grupos dominantes da pirâmide social. A partir daí começam as tentativas de conspiração contra o vingador da "Raça Negra" e da América, tal como conhecido no imaginário haitiano, a tal ponto que, em 17 de outubro de 1806, ele sofreu uma emboscada e é assassinado na entrada norte da cidade de Porto Príncipe, Pont-Larnage. Que se tornou,

91 Disponível em http://bibnum2.bnquebec.ca/bna/rfn_ext/HT/ht_Constitution_Imperiale_1805.pdf . Acesso em: 15 de abr. de 2018. 
hoje, Pont-Rouge, Ponte vermelha; em sinal de homenagem à memória do mártir da resistência haitiana e da causa de todos os povos oprimidos na história do capitalismo.

Com efeito, para os grupos dominantes a economia de plantation foi o único modelo econômico possível para os camponeses. As plantations foram mantidas como o modelo econômico do período colonial. Mas, para os camponeses, as plantations representavam a escravidão; a sua reivindicação, portanto, era a partilha integral das terras confiscadas dos colonizadores franceses (PIERRE, 2014). Exatamente o que Dessalines tentava articular. Entretanto, estamos diante de uma estrutura social de uma sociedade em que $90 \%$ dos habitantes eram do meio rural, onde quase toda a população vivia da terra como meio de produção e de subsistência. Portanto, sem ter acesso a ela, e devido à concentração fundiária. Assim, as desigualdades entre os dois primeiros grupos (antigos e novos livres) e os camponeses se reforçaram no movimento da formação da nação haitiana. As marcas das desigualdades do passado são profundas.

Dessa maneira, pode-se dizer que as desigualdades do sistema colonialista e escravocrata que precedem à independência do Haiti influenciam a composição da estrutura social da sociedade haitiana por mais de dois séculos. Segundo o economista haitiano, Leslie Péan (2007), no rescaldo da independência a terra se encontrava como motor em torno da qual as relações econômicas, sociais e políticas foram organizadas. Para o autor, a principal desigualdade no Haiti tem sido e, continua sendo, o acesso desigual à terra. Ademais, as desigualdades são evidenciadas no acesso aos recursos estratégicos para o desenvolvimento humano de uma grande parte da população como, por exemplo, a educação de qualidade. Tudo isso, contribui para reforçar outras formas de desigualdades, tais como: desigualdades socioespaciais, econômicas e culturais.

Partimos da problemática da desigualdade apontada por Péan (2007), podemos dizer que a terra e as relações em torno dela perpetuam no Haiti por meio da reprodução da classe dominante até atualidade. Isso recapitulando produz outros tipos de desigualdades o que pode ser evidenciado através da comparação internacional de coeficiente de Gini ${ }^{92}$ da desigualdade. Baseando nesse coeficiente, o Haiti fez parte de países mais desiguais da América Latina e do Caribe. Isso pode ser evidenciado a partir

92 O Índice de Gini, também, é conhecido como coeficiente de Gini é usado para indicar o grau de concentração de renda de uma região ou país. Esse coeficiente recebe esse nome em referência ao seu desenvolvedor, o matemático italiano Conrado Gini, que criou esse cálculo no ano de 1912 sob a preocupação de mensurar o quanto um determinado país ou região pode ser igualitário ou desigual social e economicamente. 
da dinâmica da desigualdade no período compreendido entre os anos de 1986/87 e 1999/00. Porém, essa situação de desigualdade se amplia no Haiti devido ao terremoto de 2010, em que seu impacto causou a descapitalização de muitos haitianos.

Quadro 3 - dinâmica da desigualdade no Haiti 1986/1987/ e 1999/2000

\begin{tabular}{|l|l|l|l|l|}
\hline Anos & RMPP & Cidades provinciais & No campo & Total \\
\hline $\mathbf{1 9 8 6 / 1 9 8 7}$ & 0,40 & 0,36 & 0,47 & 0,50 \\
\hline $\mathbf{1 9 9 9 / 2 0 0 0}$ & 0,58 & 0,46 & 0,42 & 0,49 \\
\hline
\end{tabular}

Fontes: PNUD, EBCM, 2000. Organização dos dados: Ismane Desrosiers, 2018.

O quadro 3 apresenta a evolução da desigualdade no Haiti baseada no coeficiente de Gini. Nele observamos, especialmente na região metropolitana de Porto Príncipe (RMPP), que esse coeficiente de desigualdade passa de 0,40 nos anos de 1986/1987 para 0,58 nos anos 1999/2000; o que mostra um crescimento da desigualdade na metrópole de Porto Príncipe à medida que está se urbanizando. Mas essa desigualdade se revela no país como um todo. Entretanto, nos países onde a renda é distribuída de forma mais justa, o coeficiente varia entre 0,20 e 0,25 como, por exemplo, nos países escandinavos. Esses países são considerados relativamente igualitários no mundo ocidental, entretanto, temos que salientar que esses países fazem parte do centro do capitalismo e o Haiti e, os demais países latino-americanos, por sua vez, estão inseridos na periferia dominada deste sistema. Por isso, em termos de coeficiente de desigualdade, o país está no mesmo patamar dos países mais desiguais da América Latina ${ }^{93}$ como, por exemplo, Brasil, México, e El Salvador. Dessa maneira, segundo Baszabas (1997), a sociedade haitiana é uma sociedade dual baseada, na propriedade privada dos meios de produção, onde apenas $5 \%$ da população domina o processo de produção detentor de mais de $68 \%$ da riqueza do país. Essa minoria tornase cada vez mais rica. $\mathrm{O}$ autor argumenta que:

Numa sociedade onde $5 \%$ da população controle as empresas privadas, o comércio e as indústrias desde várias gerações, existem de fortes amplitudes de renda, e, portanto, de poder aquisitivo. Essa ínfima minoria da população é compõe da burguesia tradicional e de um número crescente de novos ricos. Ela dispõe de rendas que não são no mesmo referencial que aqueles da imensa maioria dos haitianos (BAZABAS, 1997, p. 89).

93 De acordo com o Banco Interamericano de Desenvolvimento (BID) entre 1998-99, o coeficiente de Gini dos países da América foi o segunte: Brasil: 0,59; México: 0,55; El Salvador: 0,51; Uruguai: 0,43. In BID: Facing up to inequality in Latin America. 1998-99 (BID, 1999). 
No mesmo sentido, em 2012, um relatório é publicado pelo Programa das Nações Unidas para o Desenvolvimento (PNUD). Ele é revelador acerca da distribuição de renda, que é muito desigual no Haiti; onde as famílias mais ricas têm $68 \%$ da renda (nacional) total. Portanto, pode-se dizer que essa situação desigualdade persiste como já vimos e argumentamos. Isso tende a aumentar à medida que o país se urbaniza. Esse estudo do PNUD mais recente sobre as desigualdades no Haiti e em alguns países do Caribe mostram que o país possui um coeficiente de desigualdade de 0,59; Jamaica 0,379, Barbados 0,489 a República Dominicana 0,49 (PNUD, 2012). Portanto, com esse coeficiente de concentração de renda o Haiti aparece como o país mais desigual do Caribe, e um dos países mais desiguais do mundo em relação à distribuição de renda como mostra o gráfico 20 de estimativa da distribuição de renda no Haiti, em 2006.

\section{Gráfico 20 - Distribuição de renda do Haiti, 2006}

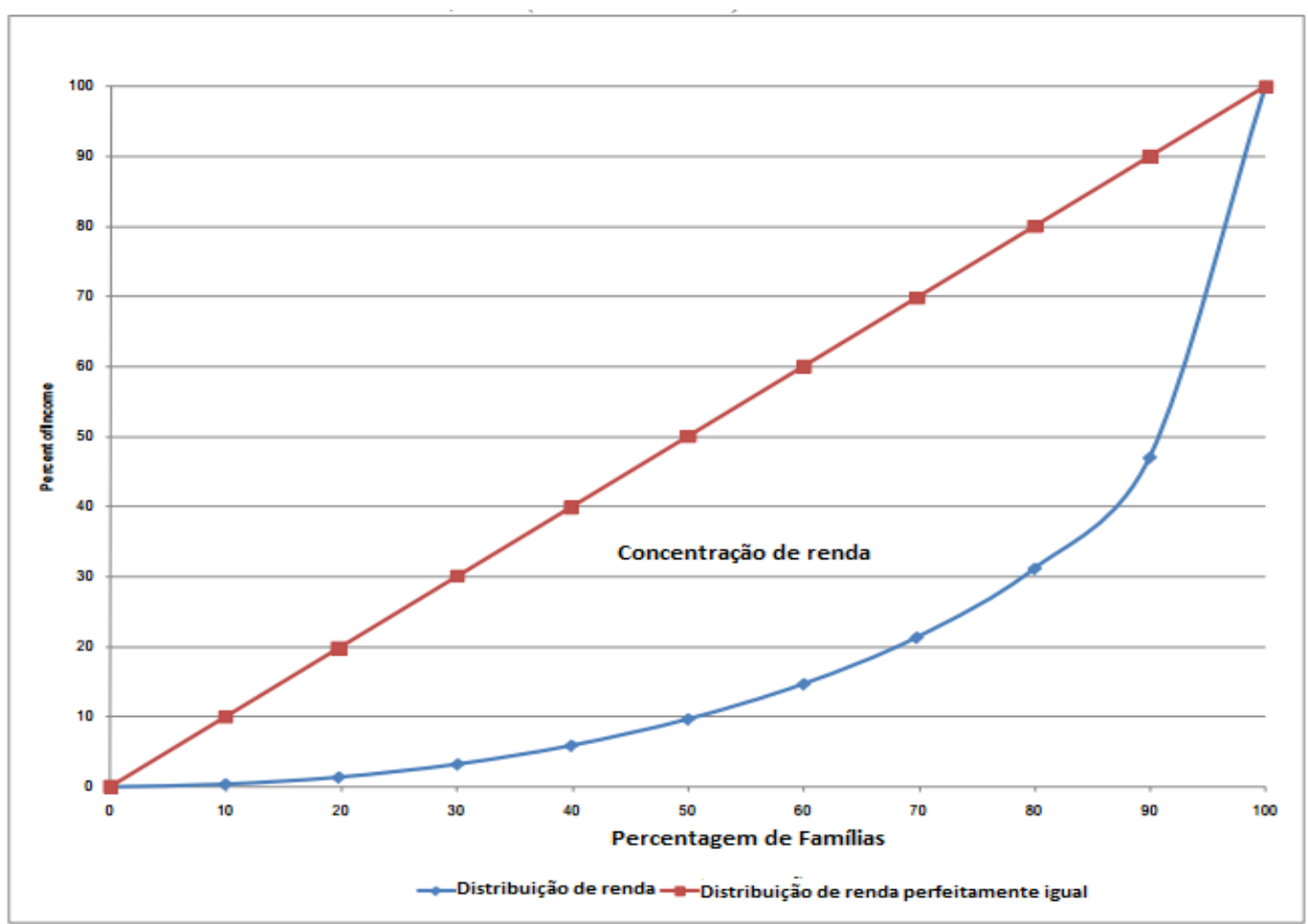

Fonte: IHSI, ECVH, 2006.

O gráfico 20 apresenta forte concentração de renda no Haiti. O coeficiente de Gini igual a zero representa o grau máximo de igualdade e só ocorre se toda cidadã e todo cidadão da sociedade apresenta a mesma renda. Por outro lado, quando o índice for igual a 1 ele representa o grau máximo de desigualdade. Isso só ocorre quando apenas um grupo na população é responsável pela concentração da totalidade dos recursos, sendo as demais populações representadas pelo valor zero. Portanto, os dois casos expostos nunca ocorrem; eles servem apenas de forma hipotética para representar a 
máxima igualdade e a máxima concentração. A partir de dados reais o Índice de Gini é sempre maior que zero e menor que 1 .

Em 2006, a análise de dados da Enquete sobre as Condições de Vida no Haiti $(\mathrm{ECVH})$ aponta, por exemplo, que o primeiro e o segundo quintil ${ }^{94}$ da população haitiana, ou seja, os $40 \%$ dos mais pobres de todas as famílias haitianas recebiam apenas cerca de $7 \%$ de toda renda anual média nacional. Enquanto isso, o quinto quintil dos $20 \%$ mais ricos da população concentrava cerca de $68,9 \%$ da renda total (IHSI, ECVH, 2006). Em 2012, dados do Instituto Haitiano Estatística e de Informática (IHSI) mostravam que a situação da distribuição de renda no Haiti continuava sendo crítica. Se dividirmos a população em cinco quintis do mesmo tamanho de $20 \%$ com a média da renda, o quintil mais pobre recebe $2 \%$ da renda, enquanto que o quintil mais rico concentra mais de $63 \%$ da renda nacional o que mostra o crescimento da desigualdade em relação à distribuição de renda como indica no gráfico 21.

Gráfico 21 - Distribuição de renda no Haiti entre 2011 e 2012

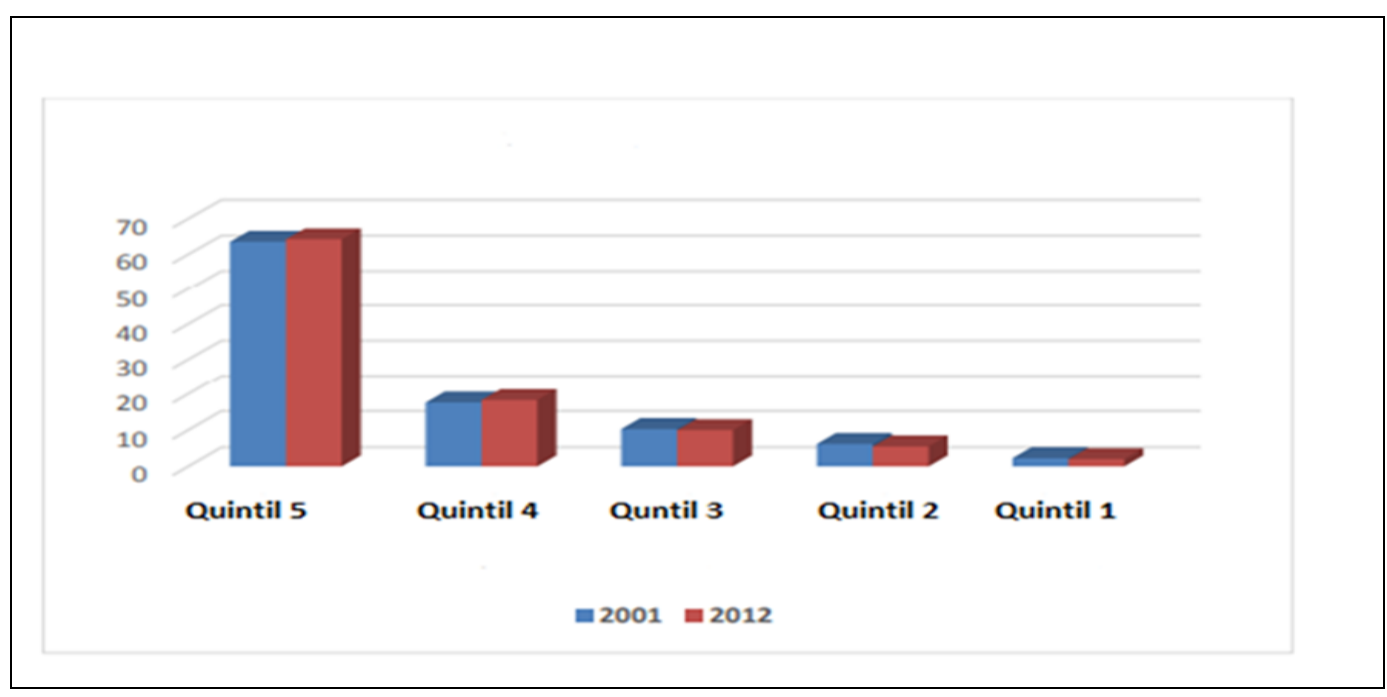

Fonte: Disponível em https://agritrop.cirad.fr/580382/1/ID580382.pdf Acesso em: 27 de agosto de 2018.

Essa distribuição de renda desigual apresentada no gráfico 21 pode ser articulada com o último estudo realizado pelo IHSI intitulado: Enquete sobre as Condições de Vida das Famílias, “Menages” Após o Sismo (ECVMAS) ${ }^{95}$ em 2012. Dados desse estudo revelam que mais de 6 milhões de haitianos vivem na pobreza, com US\$2,42

94 Um quintil representa $20 \%$ por cento de uma população num total de cinco quintis o representa, $100 \%$ da população de um país.

95 Disponível em: http://ecvmashaiti2012.e-monsite.com/medias/files/rapport-provisoire-ecvmas-mars2014.pdf Acesso em: 5 de jul. de 2019. 
por dia, e 2,5 milhões vivem abaixo da linha de pobreza extrema, com US\$1,23 por dia no Haiti (IHSI, 2012). A região metropolitana de Porto Príncipe, por sua vez, tem uma grande proporção de pobres, que são particularmente vulneráveis a choques econômicos; como no caso do aumento dos custos de alimentos. Em 2012, há na cidade cerca de 725.000 pessoas vivendo na pobreza (29\%), das quais cerca de 125.000 estão em extrema pobreza $(5 \%)^{96}$. Como aponta Corten (2011), citado por Pierre (2014) no seu estudo sobre a economia e sobre a corrupção no Haiti em que ele disse:

$\mathrm{Na}$ sociedade haitiana há uma lacuna intransponível entre os $80 \%$ da população que vive na miséria e a sobrevivência perpétua e os $20 \%$ que tentam funcionar em um modo de comportamento e consumo moderno, dos quais $7 \%$ têm renda de entre US\$ 700 e US\$ 4000 e $1 \%$ da renda acima de US\$ 4.000. Essa fratura radical resulta em uma relação constitutiva de desprezo social que não apenas se opõe ao povo, ou seja, $95 \%$ da população contra os outros $5 \%$ haitianos mais ricos, bem como estrangeiros de alta renda (CORTEN, 2011, p. 15) apud (PIERRE, 2014, p. 75).

Portanto, as desigualdades sociais são marcantes no Haiti. E, na cidade de Porto Príncipe, por sua vez, como tentamos mostrar no segundo capítulo da Dissertação, que do ponto de vista habitacional, as desigualdades socioespaciais são gritantes. A estrutura da sociedade haitiana que tentamos descrever tem uma elite econômica por conta de sua diversidade compõe de grandes famílias de latifundiários antigamente ligados e ainda aos poderes políticos. Eles monopolizam a propriedade da terra e os meios de produção resultam nas desigualdades socioeconômicas que produzem extrema pobreza, a exclusão social na metrópole Porto Príncipe e, no Haiti como o todo. Eles são os únicos atuando no setor bancário, donos de supermercados, hotéis, exportadores de produtos da indústria têxtil, de commodities nacionais como café, cacau, algodão, sisal, rhum e mangas. Essa elite é tensa em seus interesses imediatos por meio de uma economia de rentista. Além disso, revela-se bastante medíocre em suas conquistas, bem como no seu pensamento por não contribuir no desenvolvimento das forças produtivas da economia nacional. Mostra-se sua distância à grande massa por meio de suas casas de luxas que simbolizam seu poder econômico em Pétion Ville, Bel Vil e Vivi Mitchel bem como por carros novos que valem milhares de dólares, feriados na Europa, na Ásia e nos EUA enquanto a maioria dos haitianos vive numa situação de privação.

96 World Bank. Investing in people to fight poverty in Haiti. Reflections for evidence-based policymaking. Washington, 2014. Disponível em: http://documents.worldbank.org/curated/en/222901468029372321/pdf/944300v10REPLA0sment0EN0we b0version.pdf Acesso em: 29 de ago. de 2018. 


\subsection{Efeitos da corrupção na dinâmica das desigualdades no Haiti}

As desigualdades sociais no Haiti é uma construção social inerente à formação socioespacial do país, bem como ao sistema capitalista. Com efeito, dados socioeconômicos mais recentes do Instituto Haitiano de Estatística e de Informática (IHSI) em 2012 apontam a concentração de renda nas mãos de um grupo restrito da população haitiana mencionado anteriormente. No movimento da sociedade, outro elemento que alimenta as desigualdades no Haiti é a corrupção. Esse flagelo atinge desde os países ${ }^{97}$ desenvolvidos até os países mais pobres em todo o planeta em diferentes graus. A corrupção ${ }^{98}$ segundo Banco Mundial afeta o desenvolvimento socioeconômico dos países. Portanto, se o Haiti é considerado como o país mais pobre da América (BM, 2018), acreditamos que é a corrupção que contribui para esse quadro.

Com efeito, no que tange à corrupção no Haiti, os estudos de Péan (1990, 2005, 2006, 2007) mostram que os recursos financeiros que devem ser projetados junto aos projetos de desenvolvimento socioeconômicos do país como: a educação, a saúde, os programas de habitação, de infraestrutura, a geração de emprego são sujeitos a desvios. Dessa maneira, a percepção da corrupção no Haiti pode ser evidenciada, também, a partir do relatório da Transparency International (TI), em 2004 sob o tema específico da "Corrupção Política". Nesse estudo em questão, o Haiti está entre os três países mais corruptos do mundo, com a Nigéria e Bangladesh ${ }^{99}$, em que o Índice de Percepção da Corrupção (IPC) ${ }^{100}$ localiza o país na categoria de países classificados como os mais

97 Mais informações disponíveis em: http://www.doc-developpement-durable.org/documentspedagogiques-de-sensibilisation/LutteContreLaCorruption.pdf. Acesso em: 15 de setembro de 2018.

98 A definição mais comumente aceita é a utilizada pelo Banco Mundial e pela Transparência Internacional, que considera a corrupção como "o abuso do poder conferido por um serviço público para fins de enriquecimento pessoal, em detrimento da Nação e do Povo. A corrupção ativa envolve oferecer ou procurar obter dinheiro, uma garantia ou um benefício por serviços prestados. A corrupção é passiva quando um funcionário público ou funcionário recebe presentes, dinheiro, garantias ou benefícios pelos quais ele concorda em abusar de sua posição para beneficiar a pessoa que iniciou o negócio. Distingue-se A grande corrupção está presente quando políticos ou burocratas políticos de alto nível abusam do poder em que investem para enriquecer a si próprios ou a seu poder ilegalmente. A pequena corrupção está no outro extremo do espectro: é o trabalho de funcionários públicos e burocratas de baixo escalão que aproveitam sua situação para aceitar subornos, extrair dinheiro do Estado ou desviar pequenas quantias de dinheiro' colocar dinheiro em seus bolsos

99Informações disponíveis no Relatório Global sobre Corrupção 2004. Edição Karthala. Paris, 2004

100 O índice de percepção de corrupção avalia a percepção do nível de corrupção que afeta as administrações públicas e a classe política de um grupo de países. Segundo a Transparency International (TI), o Índice de Percepção da Corrupção (IPC), o índice composto com base em várias pesquisas e pesquisas realizadas por organizações independentes. Ele classifica os países em uma escala de 0 (alto grau de corrupção percebida) a 10 (baixo nível percebido de corrupção). Em 2008, por exemplo, 180 países foram envolvidos nesta pesquisa. Países como Dinamarca, Nova Zelândia e Suécia marcaram 9,3 no topo do ranking. Outros países, como Bélgica, França, Espanha e Itália, pontuaram 7,3, 6,9, 6,5 e 4,8, 
corruptos do mundo. Isso é demostrado no quadro 4 da dinâmica do índice da percepção da corrupção no Haiti de 2002 a 2014.

Quadro 4 - Índice de Percepção de Corrupção no Haiti de 2002 a 2014

\begin{tabular}{|l|l|l|l|}
\hline Anos & Ponto IPC & Ranking & Números de países \\
\hline $\mathbf{2 0 0 2}$ & 2.2 & 89 & 102 \\
\hline $\mathbf{2 0 0 3}$ & 1.5 & 131 & 133 \\
\hline $\mathbf{2 0 0 4}$ & 1.5 & 146 & 146 \\
\hline $\mathbf{2 0 0 5}$ & 1.8 & 155 & 159 \\
\hline $\mathbf{2 0 0 6}$ & 1.8 & 163 & 163 \\
\hline $\mathbf{2 0 0 7}$ & 1.6 & 177 & 180 \\
\hline $\mathbf{2 0 0 8}$ & 1.4 & 177 & 180 \\
\hline $\mathbf{2 0 0 9}$ & 1.8 & 168 & 180 \\
\hline $\mathbf{2 0 1 0}$ & 2.2 & 146 & 178 \\
\hline $\mathbf{2 0 1 1}$ & 1.8 & 175 & 183 \\
\hline $\mathbf{2 0 1 2}$ & 1.9 & 165 & 176 \\
\hline $\mathbf{2 0 1 3}$ & 1.9 & 163 & 177 \\
\hline $\mathbf{2 0 1 4}$ & 1.7 & 157 & 180 \\
\hline
\end{tabular}

Fonte: Disponível em: http://www.transparencefrance.org/ewb_pages/Acesso em: 03 de set. de 2018.

O quadro 4 mostra a dinâmica do índice da percepção de corrupção no Haiti durante as últimas duas décadas. Mas, de acordo com Leslie Péan (1990), a sociedade haitiana é historicamente arruinada pela corrupção por meio das representações sociais e instituições. Esse autor, em seu livro intitulado Haiti, Economia Política da Corrupção 1791 a 1990 (1990), faz uma análise histórica da constituição da corrupção no país. O economista haitiano propõe-se traçar uma perspectiva geral sobre a corrupção no tempo e no espaço. Para Péan, a corrupção é uma herança do período da colonização francesa que continua até nos dias de hoje. Ele afirma o seguinte:

A França decidiu desde o começo corromper o Haiti. Tudo isso, com o pagamento de subornos aos comandantes nos portos comerciais do Haiti, com a aceitação da dívida da independência pelo presidente Jean Pierre Boyer, em 1825. Essas ações arruinaram o Haiti e o deixaram em um Estado deplorável e saqueado antes de destruí-lo como um Estado independente, em 1915, com a ocupação americana do Haiti. (Grifo nosso) [...] A exclusão das massas populares foi consagrada e o desencantamento estabelecido nas relações dominadas e dominantes (PEAN, 1990, p. 59). 
De acordo com Péan (1990), a corrupção existe antes da fundação do Estado haitiano no início do século XIX. Contudo, para o autor o início da inflação das percepções associadas à corrupção no Haiti é concomitante com a queda do regime autoritário dos Duvalier em 1986. Depois de quase 30 anos no poder (1957-1986), com a perda de apoio dos Estados Unidos da América no contexto, também, de uma revolta popular, em 1986, levou à derrubada do que a historiografia haitiana contemporânea assinala como o regime político mais repressivo do século XX (PEAN, 2005). Esse regime totalitário e corrupto emerge como a própria negação dos direitos às liberdades individuais e coletivas dos haitianos no referido período. Nessa direção, foi constituído o grupo armado TonTon Macoutes (TTM), uma espécie (milícia) paralela às instituições militares e policiais que foi usado pelo ditador, Duvalier para assassinatos, queimas de arquivo e represálias contra os oponentes políticos. A elite intelectual do país, por sua vez, que constitui o fermento da oposição, é forçada ao exílio (PEAN, 2005).

Para a nossa argumentação a respeito do fenômeno da corrupção e sua relação às desigualdades sociais no Haiti, verificamos vários estudos que revelam enormes somas de dinheiro que são desviadas pelos Duvalier durante seus trinta (30) anos de reinado no poder no Haiti. Esse é o caso de estudos de Perchellet (2010), citado por Pierre (2014) que mostra entre 1957 até 1986, a dívida externa do país foi multiplicada por 17,5; o que representava US\$ 750 milhões no momento da queda regime, em 1986. Em 2009, outro estudo do Comitê Católico Contra a Fome e para o Desenvolvimento Solidário $(\mathrm{CCFD})^{101}$ menciona uma fortuna pessoal da família de Duvalier no valor de US\$ 900 milhões. Dois anos antes deste estudo, em 2007, o Banco Mundial, por meio da Transparency International, afirma que os fundos desviados por Jean Claude Duvalier (Baby Doc) são estimados entre US\$ 300 e 800 milhões (BM/ TI, 2007). Ainda mais impressionante é a estimativa do Escritório das Nações Unidas sobre Drogas e Crime dos montantes desviados: estão entre US\$ 500 milhões a dois bilhões (PIERRE, 2014, p. 86), enquanto a população haitiana enfrenta problemas em termos de acesso aos serviços básicos, desemprego, subemprego, moradia precária, desigualdades socioespaciais no meio de um processo de urbanização, principalmente, na metrópole Porto Príncipe. Quantos projetos sociais essas somas de dinheiro poderiam ser realizados com o propde diminuir as desigualdades no Haiti? 
Com efeito, estudos mostram que no Haiti a má governança e a corrupção afetam o funcionamento das instituições públicas e privadas. Dessa maneira, a extensão da corrupção nos os últimos 30 anos levanta a preocupação da sociedade civil haitiana organizada e das instituições internacionais. Nesse sentido, recapitulando um estudo publicado em 2004, pela Transparency International, sobre o Índice de Percepção da Corrupção em que o Haiti fica em $3^{\circ}$ lugar entre as nações mais corruptas do planeta (BM/TI, 2004).

Na mesma ideia em 2007, a Unidade de Luta Contra a Corrupção (ULCC) publicou, um estudo intitulado Pesquisa sobre Governança e Corrupção no Haiti ${ }^{102}$. Os resultados desse estudo ressaltam a estrutura do Estado permite a corrupção, sobretudo, na administração pública. O estudo aponta as causas da corrupção no Haiti que são as seguintes: a ausência de um sistema eficaz de denúncia de corrupção, salários inadequados de funcionários do setor público, falta de um sistema judiciário independente e efetivo, falta de um processo político transparente e responsável, falta de um mecanismo eficaz para motivar os funcionários do setor público. Tudo isso, em termos de reconhecimento de mérito, falta de meios de comunicação eficazes, razões culturais, más políticas econômicas (HAITI/ULCC, 2007, p.109). Isso mostra o grau de impunidade no Haiti. Não seria melhor falar de falta de ética e de integridade?

Gráfico 22 - Setores envolvidos em casos de corrupção no Haiti

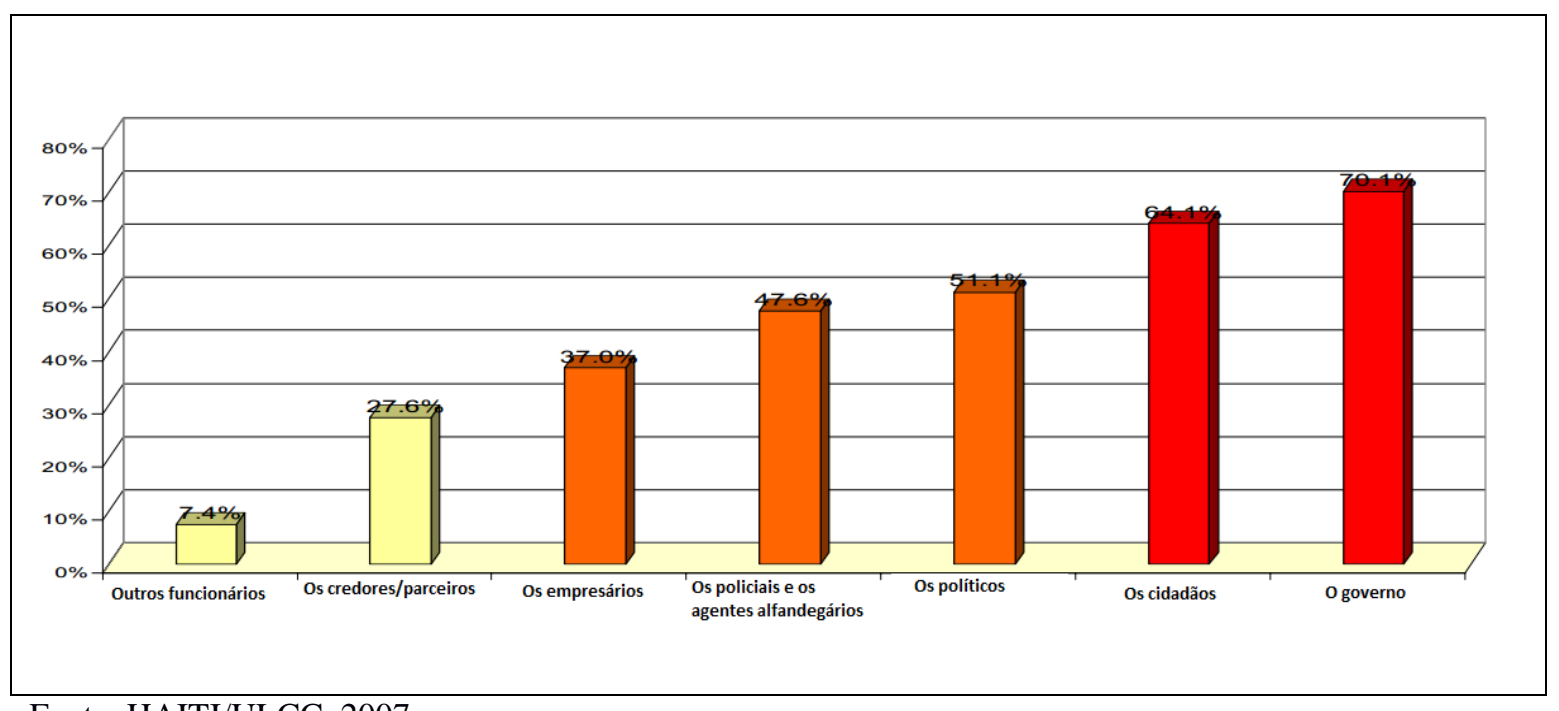

Fonte: HAITI/ULCC, 2007.

O gráfico 22 indica os principais setores que implicam na corrupção no Haiti. Isso desde as Organizações Não Governamentais (ONGs), agentes credores/parceiros

102 Disponível em: http://ulcc.gouv.ht/wp-content/uploads/2014/02/Enquete-corruption-et-gouvernance2005.pdf. Acesso em: 15 de mar. de 2019. 
financeiros internacionais até o governo. Portanto, esse último é concebi como agente supostamente mais corrupto no referido estudo sobre a corrupção publicado, em 2007. Isso mostra o grau desse fenômeno no país em que a corrupção é o meio mais fácil para emancipação socioeconômica em toda impunidade.

Mais de dez (10) anos desse estudo sobre a corrupção no Haiti que consideramos como um dos fatores que reforça as desigualdades sociais no Haiti há, na atualidade um debate no país sobre o possível desvio de US\$ 3.8 bilhões. Esses recursos financeiros são obtidos da cooperação energética denominada: PetroCaribe ${ }^{103}$ com a Venezuela, entre 2008 a 2016. O PetroCaribe é um acordo de cooperação energética assinado em 2005, com mais 14 países. Objetiva-se alcançar a integração dos povos da América Central e do Caribe por meio desse tipo de cooperação e com base em um modelo de troca justa e favorável a esses países. Ou seja, esse acordo incentiva o desenvolvimento social e econômico da região a partir de cinco princípios diretores: unidade, solidariedade, cooperação, complementaridade e visão do Sul. Desse modo, esse acordo estimula a produção local através da troca de bens e de serviços por combustíveis. À vista disso, o objetivo final é fortalecer a segurança e a soberania das nações da região e promover importantes projetos sociais e produtivos. No caso do Haiti, cabe salientar que a relação de solidariedade, diplomática e geopolítica com a Venezuela não data de hoje. Essa relação possui raízes históricas profundas, como descreve Gary Olus num artigo publicado em 2011, no AlterPresse (Haiti) sob o título o Haiti-Venezuela: sobre os traços de Pétion e Bolívar ${ }^{104}$. Assim, esse acordo PetroCaribe garantiu ao Haiti desde setembro de 2007, derivados de petróleo a preço de mercado internacional, mas em condições preferenciais de pagamento.

103 Em 29 de junho de 2005, em Puerto La Cruz, na Venezuela, os Chefes de Estados e de Governos de 14 países (Antígua e Barbuda, Bahamas, Belize, Cuba, República Dominicana, Granada, Guiana, Jamaica, St. Vicente e Granadinas, Santa Lúcia, Saint Kitts e Nevis, Suriname e Venezuela) assinam o acordo Petrocaribe, após considerarem que a crise global, a situação energética global e seus efeitos no aumento dos preços dos combustíveis afetavam negativamente e de forma crescente o desempenho econômico e a situação social dos países do Caribe, agravados pela queda dos preços de suas exportações, principalmente de produtos agrícolas. O Haiti, por sua vez, se juntou ao acordo PetroCaribe após a implementação do mesmo, em outubro e novembro de 2007. Foi assim que começou um processo de cooperação, que foi fundamental ao longo do tempo para o processo de desenvolvimento do Haiti. Os desafios do Haiti são imensos, dada sua alta vulnerabilidade a desastres naturais, como tempestades tropicais, secas, enchentes e terremotos. Como mais de dois terços dos haitianos vivem da agricultura, os desastres naturais têm um efeito devastador, pois destroem o sustento das famílias, resultando em uma grave situação de insegurança alimentar. No caso do terremoto de 2010, PetroCaribe, em solidariedade, eliminou a dívida externa do Haiti havia adquirido até essa data no contexto do acordo, continuou a enviar combustível para apoiar a geração de energia.

104 Disponível em: http://www.alterpresse.org/spip.php?article12539\#.W42SeSRKjIU Acesso em: 06 de set. de 2018. 
Nesse sentido, ressaltamos que por trás desse acordo do PetroCaribe da Venezuela com os países da América Central e do Caribe há interesse geopolítico entre a Venezuela e os Estados Unidos. Essa área da América do Norte está historicamente sob a influência norte-americana desde a aplicação de sua política intervencionista por meio da chamada Doutrina de Monroe no século XIX. Portanto, analisamos esse jogo de interesse da seguinte maneira: de um lado, o país latino-americano busca novos aliados na América Central e no Caribe contra o isolamento do império norteamericano; por outro, a maioria desses países são clientes de empresas petroleiras dos Estados Unidos, inclusive o Haiti antes do referido acordo com o país sul-americano.

No âmbito da implementação do acordo supramencionado e outro apoio externo, foi criado o Escritório de Monetização de Programas de Assistência ao Desenvolvimento (BMPAD). Essa instituição é responsável pela implementação deste acordo que serve, nessa direção, como uma interface entre o fornecedor Petróleos de Venezuela S.A. (PDVSA) e as companhias petrolíferas locais. Essa instituição estatal adquire derivados de petróleo venezuelanos e os vende para empresas nacionais. Essas últimas tem um prazo de 30 dias para pagar 100\% à BMPAD em vista dos valores faturados. No entanto, com relação ao pagamento venezuelano, o acordo PetroCaribe define os seguintes termos: uma parcela à vista deve ser paga dentro de 90 dias da data do conhecimento de embarque dos produtos sem juros para os 30 primeiros dias, e com juros de $2 \%$, a partir do dia 31 até 90 . A parcela financiada é maior quando o preço dos derivados de petróleo está alto. O restante é pagável dentro de um período de 25 anos com uma porcentagem de $1 \%$ de juros anuais. A parte financiada (lucros) gerada através do acordo PetroCaribe, deve ser usada para financiar projetos de desenvolvimento (infraestrutura, educação, saúde, agricultura, habitação social, infraestruturas esportivas) como ocorre em outros países signatários desse acordo.

Mas, um inquérito ${ }^{105}$ parlamentar sobre a utilização dos recursos financeiros do PetroCaribe entre 2008 a 2016, feito pelo Senado da República do Haiti, e publicado em 2017, mostra que os recursos projetados para ser investidos nos projetos de desenvolvimentos listados anteriormente são supostamente desviados no valor de US\$ 3.8 bilhões. Esse inquérito foi entregue à Corte Supremo de Contas e de Contencioso Administrativo (CSC/CA) para aprofundamento da investigação fornecendo, portanto 
uma descrição detalhada do uso de fundos pelos governos que serviram o país de 2008 a 2016. O tribunal, por sua vez, apresenta, em 31 de maio de 2019, seu relatório final ${ }^{106}$ de 612 páginas sobre o uso dos fundos PetroCaribe que revela o valor supostamente desviado no referido período é estimado a US\$ 4.2 bilhões. Nesse relatório, vários ministros, diretores gerais, empresas e inclusive o atual presidente da República, Jovenel Moïse são acusados de corrupção. Com efeito, no relatório o tribunal de contas relata uma "descoberta preocupante", pois, em 2014, para o mesmo projeto de reabilitação da rodoviária de Borgne-Petit Bourg de Borgne, no Norte do país, o Estado assinou dois contratos idênticos no valor de mais US\$ 4 milhões de (GTH 39 milhões) com empresa AGRITRANS S.A e a empresa BETEXS com mais de US\$ 3 milhões (GTH 34 milhões) separadas, das quais Jovenel Moïse foi presidente em 2014, antes de ser eleito presidente do Haiti, em 2016 (CSC/CA, 2019, p. 157 a 182). Essas duas empresas apresentam os mesmos documentos separadamente nas mesmas datas e referem-se a "um esquema de apropriação indébita" nas palavras do Tribunal de Contas. A mais alta jurisdição financeira e administrativa do Haiti aponta a responsabilidade do Presidente Jovenel Moïse no esquema de corrupção (CSC/CA, p. 169).

Em suma, nesse relatório, o tribunal demonstra que as principais etapas relacionadas com a boa gestão dos projetos de desenvolvimento do Haiti no âmbito do acordo PetroCaribe entre 2008 e 2016 não foram seguidas e, ao fazê-lo, os projetos de investimentos e os contratos relacionados com os fundos PetroCaribe não foram geridos de forma eficiente e econômica. Portanto nenhuma preocupação com as gerações futuras foi levada em consideração. Contudo, reivindicado por várias organizações da sociedade civil, cujo, PetroChallengers ${ }^{107}$ e membros da oposição política cremos que, o relatório final da Corte deve marcar a principal etapa no processo de julgamento dos principais corruptores e corruptos dos fundos PetroCaribe. Já que desde no final do mês de agosto de 2018 observamos, no Haiti uma onda de protestos; principalmente na cidade de Porto Príncipe para que os prováveis corruptos sejam julgados inclusive a renúncia do presidente da República para se colocar à disposição da justiça haitiana. A população nesses protestos perguntando: Cadê o dinheiro do PetroCaribe? Kote kòb PetroCaribe a? em língua crioulo haitiano.

106 Disponível em: https://constanthaiti.info/rapport-final-2-cscca-petrocaribe-612-pages/ . Acesso em: 03 de jun. de 2019.

107 Movimento que emerge por meio das redes sociais liderado, especialmente, por jovens desde 2018 que se transformou em numerosas manifestações de rua contra a corrupção, principalmente, contra supostamente o desvio de US\$ 4.2 bilhões entre 2008 a 2016 do programa PetroCaribe. 
Cremos para que haja o julgamento do PetroCaribe, as manifestações de rua devem continuar e ampliar para forçar mais haitianos a perceberem o enorme desperdício orquestrado com o fundo PetroCaribe no contexto pós-terremoto. Longe do Haiti há 8 anos, porém, consciente da situação socioeconômica em que vive a população haitiana. Por isso, queremos saber, também onde está o dinheiro PetroCaribe?

Figura 22 - Manifestação contra a corrupção em Porto Príncipe, 2018

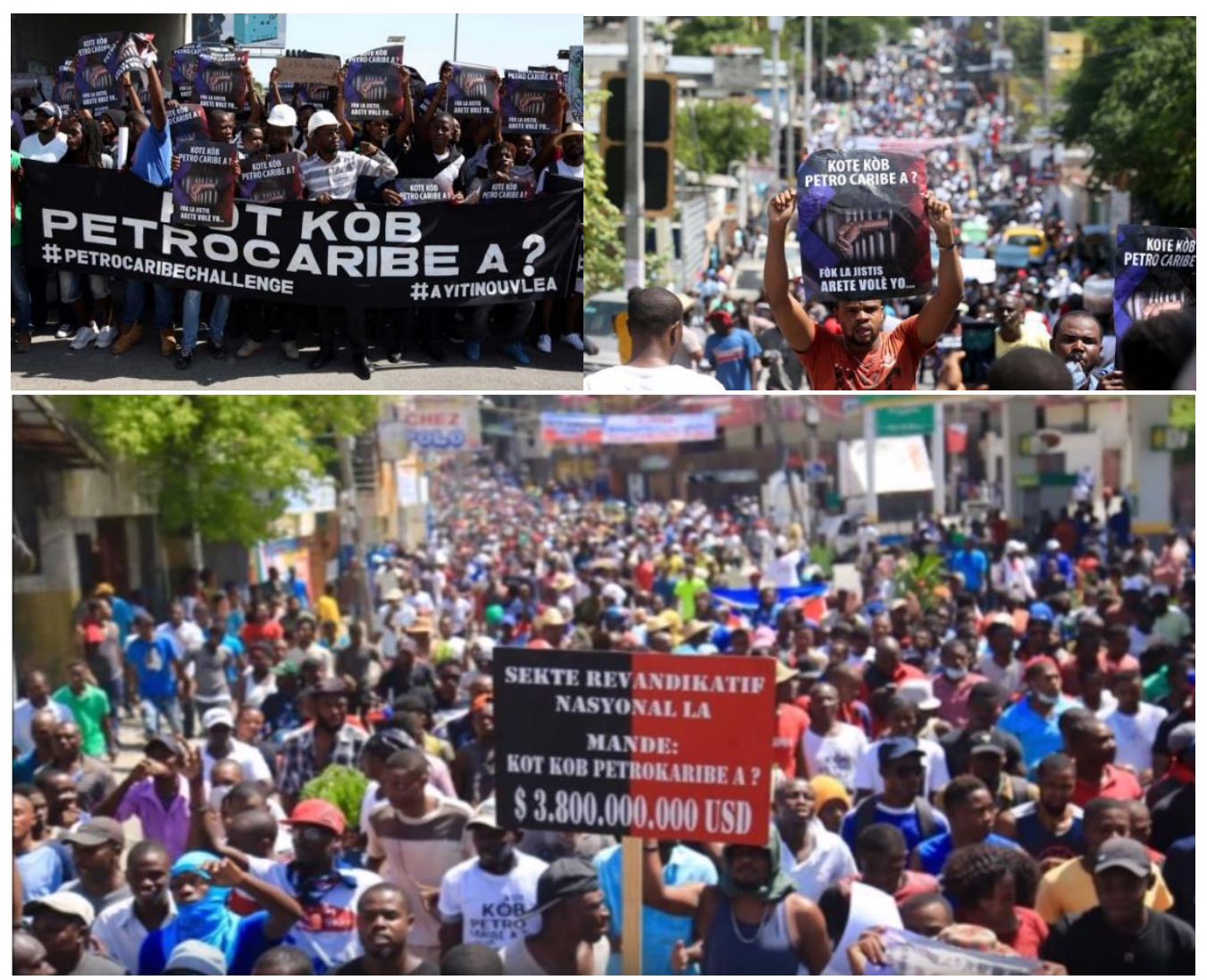

Fonte: Organização: Ismane Desrosiers, 2019.

Essa quantia de dinheiro que foi prevista para ser investida nos projetos de desenvolvimento do Haiti está em contradição com a realidade, sobretudo, no contexto da reconstrução do Haiti no pós-terremoto de 2010. Uma reconstrução como foi mencionando no primeiro capítulo desta Dissertação que está em um impasse devido, principalmente, aos problemas de financiamentos, especialmente, o chamado projeto de requalificação urbana de Porto Príncipe, a Cidade Administrativa. Esse, também, não propõe uma melhoria das condições de vida da população urbana na cidade, especialmente, para os mais pobres. Portanto, pode-se dizer que os montantes supostamente desviados durante esses últimos dez (10) anos potencializam as desigualdades sociais no Haiti e amplia as desigualdades socioespaciais na metrópole de Porto Príncipe. 


\section{CONSIDERAÇÕES FINAIS}

Esta Dissertação de Mestrado teve como objetivo analisar as desigualdades sociais no Haiti, bem como as desigualdades socioespaciais na metrópole Porto Príncipe na atualidade. Nesse sentido, a partir da nossa problemática de pesquisa podemos dizer que a situação atual da cidade e do Haiti como um todo tem vindo de três fatores principais: a dominação externa do país inserido na periferia do capitalismo, a concentração fundiária e a corrupção. Como foi demostrado no trabalho, a dominação externa privou o país da capacidade de desenvolvimento socioeconômico ao longo do século XIX por meio de bloqueio diplomático, comercial e de indenização injusta à França. Isso impediu, de alguma forma, o Estado haitiano de desenvolver as infraestruturas básicas do país no decorrer do século supramencionado.

Na mesma ideia de dominação externa, com a emergência do neoliberalismo nos anos de 1980, o Haiti foi obrigado, assim como vários países da América Latina e do Caribe, a assinar acordos, planos e programas com as instituições de financiamentos internacionais. Tudo isso por meio de políticas de ajustamento estrutural que defendem a intervenção mínima do Estado na economia reforçaram assim medidas liberalizantes. Constatamos que as estratégias neoliberais enfraqueceram o Estado haitiano e os governos, privando-os dos recursos necessários para assumir sua responsabilidade republicana. Portanto, aceitando os planos neoliberais, o Estado haitiano hipotecou, assim, toda a sua autonomia econômica impedindo, de alguma forma, impulsionar o desenvolvimento socioeconômico do país visando o bem-estar coletivo na atualidade.

Nesse sentido, a liberalização comercial contribui na "destruição" da base da produção nacional pela concorrência desigual entre os produtos importados e produtos nacionais agravaram as desigualdades sociais no nosso país. Assim, o Haiti está se tornando cada vez mais dependente do financiamento externo que vem, principalmente, das Instituições de Financiamentos Internacionais. Ao organizar essa situação de dependência, as IFI a impor as suas condições. Isso significa na prática o congelamento ou uma queda nos investimentos públicos para pagar uma dívida ilegítima e obedecer às injunções desses credores. Dessa maneira, infelizmente é a população que paga o preço já que os empréstimos são sujeitos a desvios por meio da corrupção. Nessa direção, observamos, principalmente que desde a década de 1980, prevalecem os interesses de uma elite capitalista local e estrangeira em detrimento da produção nacional reforçando as desigualdades sociais no Haiti. Salientamos que os principais culpados disso, primeiro são as elites políticas e econômicas que estão à frente do país desde 1804 . 
A urbanização ocorre por várias razões que evidenciamos ao longo do trabalho sem o processo de industrialização do Haiti. Diante disso, a urbanização acelerada vista no Haiti, principalmente na cidade Porto Príncipe, a nosso ver é um deslocamento populacional simplesmente caracterizado por uma mudança de ocupação em termos de atividades agrícolas precárias no campo para atividades econômicas de subsistências nas cidades, em particular, na metrópole Porto Príncipe. Portanto, essa mudança não evidencia uma melhor condição de vida na cidade. Isso tudo, uma vez que a elite econômica, melhor dizendo, os mercadores haitianos, representados por descendentes europeus sírio-libaneses ${ }^{108}$ que controlem a economia do país não investirem de forma adequada para desenvolver as forças produtivas da economia nacional. Portanto, a escolha das elites econômica e política, especialmente desde 1980, não contribuem a desencadear o desenvolvimento industrial do país, mas, preferem incorporar com as elites globais que nunca têm interesses considerar necessário impulsionar a produção industrial nacional, para o aumento do produto interno bruto e a diversificação da economia do nosso país. Pelo contrário, a pouca riqueza socialmente produzida no Haiti, está sendo apropriada por esta elite parasitária.

Neste contexto de estagnação econômica e de desigualdades sociais historicamente construídas no Haiti ocorre o terremoto de 2010, em que os impactos do evento pioraram a situação socioeconômica e infrraestrutural do país. Nessa direção, a pesquisa faz ver, um aumento das desigualdades socioespaciais evidenciado pala urbanização de novas áreas no grande Porto Príncipe em que as condições de vida são precárias. Portanto, são situações análogas em vários bairros já consolidados antes de 2010. Isso mostra, de alguma maneira, que a demanda excessiva da justiça espacial das massas urbanas que vivem nesses bairros em relação aos grupos abastados têm suas explicações na concentração da riqueza do país na mão dessa elite econômica e a elite política supostamente envolvida em casos de corrupção, principalmente nos últimos 30 anos.

108 Atualmente, uma grande parte do monopólio da economia é controlada por descentes sírio-libaneses no Haiti. Eles chegaram ao país na virada do século XX. Durante este período, cerca de 15.000 síriolibaneses, a maioria é dos territórios do Oriente Médio controlados pela França. Nessa época eles fugiram de guerra e de miséria em busca de uma vida melhor no Haiti. Logo eles prosperaram como comerciantes e mercadores. Muitas dessas famílias estão agora envolvidas na importação e exportação e estão entre as principais figuras da economia haitiana (PIERRE, 2014). Eles estão frequentemente em competição econômica com outros grupos influentes, incluindo o grupo de mulatos, nascidos no Haiti do vínculo dos brancos e escravizadas negras, eles representavam na época da Revolução Haitiana cerca de 5\% da população. Hoje, dados estatísticos sobre sua porcentagem na sociedade haitiana não são disponíveis. 
No contexto pós-terremoto, como vimos o Haiti, em particular, a metrópole Porto Príncipe faz objeto de vários planos, programas e projeto de reconstrução. Entre eles destacamos o projeto de requalificação urbana proposto pela Fundação Príncipe Charles, do Reino Unido, sobretudo, o projeto articulado pelo governo haitiano, a chamada Cidade Administrativa. Desvendamos que esse referido projeto é excludente. Ademais, leva-se em conta somente a função administrativa da cidade. Nessa direção, o setor habitacional que nunca acompanha o crescimento populacional no Haiti e que foi severamente afetado pelo terremoto está sendo deixado de lado nos planos de reconstrução da cidade pós-catástrofe. Desta forma, desvendamos ainda que na reconstrução do Haiti, em particular, a cidade de Porto Príncipe, a realização de projetos habitacionais pelas Organizações Não Governamentais (ONGs) no período emergencial pós-desastre de 2010 não tem um impacto importante. Pelo contrário, suas intervenções até contribuem no aumento da problemática urbana com a criação e a expansão urbana no norte da cidade. Portanto, é improvável que as iniciativas tomadas pelas ONGs possam gerar as transformações substanciais e estruturantes capazes de melhorar as condições de vida no Haiti, notadamente, as de habitacionais.

Nesse sentido, cremos que a reconstrução do Haiti, especialmente, a da metrópole Porto Príncipe não se realiza com base na caridade internacional. É um projeto nacional, difícil e longo da comunidade haitiana, em que residem as capacidades virtuais de transformação como era uma vez, reduzida à escravidão e se levantou contra as desigualdades perante o trabalho livre e escravo, contra a injustiça social. Desta maneira, o Haiti promove no mundo inteiro o respeito da dignidade humana e dos direitos fundamentais dos seres humanos. Infelizmente, há mais de duzentos (200) anos desse agir haitiano por um mundo mais justo, por várias razões explicadas ao longo da Dissertação, os direitos básicos da maioria dos haitianos não são respeitados.

Dentro desse projeto de reconstrução nacional a questão da modernização do Haiti, especialmente, da metrópole Porto Príncipe tem que ser levada em conta. Tudo isso, por meio da modernização da agricultura, a industrialização da economia, uma política de substituição das importações, modernização dos meios de transportes. Para que isso acontece, é necessária a conjugação de esforços entres as elites econômicas e políticas engajadas a sair o Haiti do subdesenvolvimento visando uma melhor distribuição da riqueza do país. Isso, a partir de uma consciência coletiva da realidade socioeconômica atual tendo em vista - desta vez uma "Revolução Tranquila" podendo transformar radicalmente o sistema social desigual existente no Haiti. 


\section{BIBLIOGRAFIA}

ALEXANDRE, S, W. Haïti au XVIII siècle Richesse et esclavage dans une colonie française. Editions Karthala, Paris, 1993.

ALVES, G, A. As centralidades periféricas: da segregação socioespacial ao direito à cidade. In: CARLOS A. F. A et al. de (ogrs). Geografia Urbana Crítica: teoria e método. São Paulo: Contexto, 2018; pp. 109-123.

ANGLADE, G. L'Espace haitien. Les presses de l'Université du Québec. Montréal, 1974.

Atlas critique d'Haiti. ERCE \& CRC. Groupe d'Études et de Recherches

Critiques d'Espace Département de Géographie, Université du Québec à Montréal.

Centre de Recherches Caraïbes de l'Université de Montréal. Montréal, 1982.

Cartes sur Table, Port-au-Prince, Haiti; New York, USA; Montréal, Québec:

Coédition Éditions Henri Deschamps/Études et Recherches critiques d'espace, 1990.

BAZABAS D. Du marché de rue en Haïti. Le système urbain de Port-au-Prince face à des entreprises «d'espace rue». L'harmattan, 1997, $124 \mathrm{p}$.

Banco da República do Haiti- BRH. Rapports annuels 1986 à 2005

Barrios, S. Prediagnostico Espacial: El Marco Teórico. Caracas, Cendes, Universidad Central de Venezuela, 1976.

La planification régionale en Haïti 1995. Port-au-Prince, 1995

BRAUDEL, F. Civilização material, economia e capitalismo: séculos XV-XVIII - os jogos das trocas. WMF Martins Fontes, São Paulo, 1996.

CASTELLS, M. (1972). A questão urbana. Rio de Janeiro: Paz e Terra, 1983.

CASTOR, S. L'Occupation Américaine d'Haiti 1915-1934. CHIDIAC, Port-auPrince, 1987.

CADET R. Dix-neuf ans d'Occupation américaine d'Haïti 1915-1943. La confiscation du territoire. Imprimerie Deschamp. Port-au-Prince, 2010.

CORVINGTON, G. Port-au-Prince au cours des ans. Port-au-Prince, 1972-1993.Grande oeuvre illustrée de six volumes avec des passages extraordinaires sur les tramways: v. 3, pp. 231-2, 283-5; v. 4, pp. 20-1, 71-4, 127-8, 184-5; v. 5, pp.

Port-au-Prince au cours des ans: la ville contemporaine 1934-1950. Henri

Deschamps, Port-au-Prince, 1991 b.

Port-au-Prince au cours des ans: La capital d'Haïti sous l'Occupation (1915-

1922). Henri Deschamps, Port-au-Prince, 1991a. 
COLIN, A. R. História ilustrada da Ciência da Universidade de Cambridge: Da Renascença à Revolução Científica. Volume III. Jorge Zahar. Rio de Janeiro, 1987.

CEPAL. Pauvreté et strategies de survie dans les quartiers précaires de l'aire metropolitaine de Port-au-Prince, 2005

CARLOS, A, F, A (et. al). A produção do espaço urbano: agentes e processos, escalas e desafios, São Paulo: Contexto, 2011. Os Caminhos da Reflexão sobre a Cidade e o Urbano. São Paulo: Editora USP, 1994.

A Cidade. São Paulo: Contexto, 2015.

Justiça Espacial e o Direito à Cidade. São Paulo: Contexto, 2017.

COMITÊ Interministerial de l'Aménagement Territoriale- CIAT. Haïti demain. Objectifs et stratégies territoriales pour la reconstruction, Port-au-Prince, 2014.

CORRÊA, R, L. O espaço urbano. $4^{\mathrm{a}}$ edição, $2^{\mathrm{a}}$ reimpressão. São Paulo: Editora Ática, 2000

DAMIANI, A, L. A Urbanização crítica na metrópole de São Paulo a partir de fundamentos da geografia urbana. Anais do $12{ }^{\circ}$ Encontro de Geógrafos de América Latina. Montevidéu: EGAL, 2009.

DEVIS, A. Mulheres. Raça e Classe. Boitempo, São Paulo, 2016.

DESROSIERS, I. Do Imperialismo de Estado ao domínio das Organizações Não Governamentais (ONGs): o Haiti após o terremoto de 2010. Monografia. Instituto de Geociências, Universidade Estadual de Campinas, 2016.

Haiti: um olhar crítico sobre o processo de urbanização de Canaan após

2010. Boletim Campineiro de Geografia/Associação dos Geógrafos Brasileiros AGBCampinas. v. 7, n 2, 2017. p. 383-404. Disponível em:

http://agbcampinas.com.br/bcg/index.php/boletim-campineiro/article/view/351. Acesso em: 10 de set. de 2018 .

DEVAUGES, R. Une capitale antillaise: Port-au-Prince (Haïti). Les Cahiers d'OutreMer Bordeaux, 1954, pp. 105-136.

DUPERVAL J, V. Les Implications socio-économiques de la concentration démographique dans l'aire métropolitaine de Port-au-Prince. Port-auPríncipe, 1992

DOURA, F. Économie d'Haïti. Dépendance, crises et développement. Les 
éditions Dami, tome II. Montréal, 2002.

DORSAINVIL, J,C. Manuel d'Histoire d'Haiti. Fères de l'Instruction Crétienne. Portau-Prince, $1934 . \quad$ Disponível em: http://www.manioc.org/gsdl/collect/patrimon/archives/PAP11077.dir/PAP11077.p df Acesso em: 20 de out. de 2018.

DIRENY, T. Prospective de la demande de transport en commun à Port-au-Prince. Université d'Etat d'Haiti - Maîtrise en Développement urbain et régional. 2014, Disponível em : http://www.memoireonline Acesso em: 24 de ago. de 2018.

ENGELS, F. A situação da classe trabalhadora na Inglaterra. Boitempo, São Paulo, 2008.

FRANÇA. Declaração dos Direitos do Homem e do Cidadão, Paris, 1789. Disponível em: https://www.quelsdroitsfacealapolice.be/IMG/pdf/ddhc_1789-08-26_fr.pdf. Acesso em: 8 de jun. de 2019.

FIRMIN, A. De l'égalité des races humaines. Librairie-Contillon F. Picchon, Successeur, Imprimeur-Editeur. Paeis, 1885.

FANON, F. Pele negra, máscaras brancas. Ed. Fator, Rio de Janeiro, 1983

FREIRE, P. Consciência e história: a práxis educativa de Paulo Freire (antologia). São Paulo: Loyola, 1979

HARVEY, D. A Justiça Social e a Cidade. São Paulo: Editora Hucitec. 1980.

HOLLY G. Les problèmes environnementaux de la Région Métropolitaine de Portau-Prince. Commission pour la commémoration du 250 ème anniversaire de la Fondation de la ville de Port-au-Prince. Imprimerie Henri Deschamps, 1999, 250 pages.

HECTOR, M et al. Colonisation et Esclavage en Haïti: Le régime colonial français à Saint-Domingue (1625-1789). Port-au-Prince et Montréal ed. CIDIHCA, 1990

HUGH, T. The Slave Trade: The Story of the Atlantic Slave Trade, 1440-1870. London, 1997.

HENRY A, S, et al. L'agriculture haïtienne dans l'impasse des nouvelles négociations commerciales à l'OMC , 52 pages. Port-au-Prince, 2005.

HAÏTI. Direction générale des travaux publics. Documents relatifs au service des tramways de la capitale et du Chemin de Fer de la Plaine du Cul-de-Sac. Port-auPrince, 1906. Compte rendu de textes de 1897, 1898 et 1904. Des descriptions détaillées du matériel roulant.

Constituição haitiana de 1987, Port -au-Prince, 1987. 
Politique National de Logement Et de l'Habitat, Port-au-Prince, 2013.

Document de strategie nationale pour la croissance et la réduction de la pauvreté DSNCRP (2008-2010), Port-au-Prince, 2007.

Ministère de l'Economie et des Finances (MEF): Rapport annuel 2014-2015.

Port-au-Prince, $2016 . \quad$ Disponível em:

http://www.mef.gouv.ht/upload/doc/DeeSituationEcFinSocHaitirev_20septembre2014.p

df . Acesso em: 20 de set. de 2018.

GOAL Haïti. Menm Katye, Lòt Vizaj, Schéma d'aménagement des quartiers de

Haut-Turgeau et Debussy. Port-au-Prince, 2015

GEOGES-PIERRE, A. Dumarsais Estimé, l'homme, l'œuvre et les idées. Port-au-

Prince, L'Imprimeur S.A. 2012.

GEORGE, P. Os métodos da Geografia. Rio de Janeiro: Difusão Editorial S.A., 1978.

. Panorama do Mundo Atual. $3^{\text {a }}$ ed. São Paulo: Difusão Europeias, 1970.

Geografia Industrial do Mundo. São Paulo: Difusão Editorial S.A., 1975.

GRAFMEYER, Y, J, I. L'École de Chicago. Naissance d'écologie urbaine. Aubier, Paris: 2000.

GODARD, H, R. Port-au-Prince, les mutations urbaines dans le cadre d'une croissance rapide et incontrôlée. Thèse Doctorat en Géographie soutenue à 1'Université de Bordeaux III-UER. Bordeaux, 1985.

IHSI-Instituto Haitiano de Estatística e de Informática. Analyse de quelques indicateurs Démographiques tirés des recensements de 1950, 1971, 1982 et 2003, Port- au-Prince, Vol. 2. 1983.

EPPLS. Recensements de La population et du logement, 1950, 1971, 1982, 2003, Port-au-Prince, 2012.

Étude des relations entre l'exode rural et la planification urbaine en Haïti, Port-au-Prince, 1990.

Enquête socio-économique dans les quartiers populeux, de l'aire métropolitaine de Port-au-Prince, 1988, 284 pages.

Enquête Budget Consommation des Ménages (EBCM 1999-2000). Volume 1, Population, ménages et emploi. Port- au-Prince, 2000.

Enquête sur les conditions de vie en Haïti -ECVH. Port-au-Prince, 2001.

Enquête sur les conditions de vie en Haïti - ECVH. Port-au-Prince, 2003.

L'évolution des conditions de vie en Haïti entre 2007 et 2012. La réplique sociale du séisme. Port-au-Prince, 2014. 
Ministère de l'économie et des finances \& l'Institut haïtien de statistiques et d'informatiques (2004-2005), Enquête sur le transport. 2007.

Enquete sur les Conditions de Vie des Menages Après le Seosme (ECVMAS).

2012. Disponível em: http://ecvmashaiti2012.e-monsite.com/medias/files/rapportprovisoire-ecvmas-mars-2014.pdf . Acesso em: 21 de set. de 2018.

IRAM. La tarification des principaux produits agricoles d'Haïti. Port-au-Prince, 1998.

JANVIER, L, J. Les detracteurs de la race noitre et de la République d'Haiti. Marpon et Flammarion Libraires-Éditeurs. Paris, 1882.

JOACHIM, B. Les racines du sous-développement en Haïti. Port-au-Prince, Imprimerie Deschamps, 1979.

JAMES, C, L, R. Os Jacobinos Negros: Toussaint L'Ouverture e a revolução de São Domingos. São Paulo: Boitempo, 2007. Tradução Afonso Teixeira Filho

JEAN PIERRE, J, R. La Révolution anti-esclavagiste et anti-colonialiste de SaintDomingue (1791-1804). Éd. Imprimerie Dechamps. Port-au-Prince, 1985.

LACOSTE, Y. A geografia ativa. 2 ed. São Paulo: Difusão Européia do Livro, 1968.

A geografia - isso serve, em primeiro lugar para fazer guerra. Campinas, SP: Papirus, 1985.

LEFEBVRE, H. A Reprodução das relações de produção. Porto, Edições Escorpião, 1973.

A Vida cotidiana no mundo moderno. São Paulo, Editora Ática, 1991.

O Direito à cidade. São Paulo, Centauro, 2001.

A Revolução urbana. Belo Horizonte, Editora UFMG, 2002.

Espaço e política. Belo Horizonte, Editora UFMG, 2008.

O Fim da História. Lisboa, Publicações Dom Quixote, 1971.

LOUIS, I. Haïti: combattre le déboisement ou les inégalités sociales? Alternatives sud, volume, 15-2008.

LAVALIN. Plan directeur de Port-au-Prince. MTPTC, PNUD, Haïti, 1988. Dossier no 49834

LOUIS, J, M. L'Invention d'Haiti comme société pauvre: L'herméneutique de la société pauvre haitienne. Thése de doutorat em Science Politique defendue à l' Université du Québec Montréal, 2010.

MANIGAT, L. Da hegemonia francesa ao imperialismo americano: 243-253, In Marc Ferro (org.). O livro negro do colonialismo. Rio de Janeiro: Ediouro, 2004. 
MARCONI, M, A \& LAKATOS, M, E. Fundamentos de Metodologia Científica. 5. ed. - São Paulo: Atlas 2003.

MARX, K. O Capital: Crítica da Economia Política. 3 livros, 5 volumes. São Paulo, Abril Cultural, 1988.

. O $18^{\circ}$ Brumário de Louis Bonaparte. $2^{\text {a }}$ Ed. Avante. Lisboa, 1852/2003

- Manuscritos econômico-filosóficos. (Tradução Jesus Ranieri). São Paulo:

Biotempo. 1844/2004.

MARX, K \& ENGELS, F. A ideologia alemã. (Tradução Silvio Donizete Chagas). São Paulo: Centauro, 2005.

MONTESQUIEU. O espírito das leis. Tradução: Cristina Muchaco. São Paulo. Martins Fontes, 2000.

NOËL, R. Migration et gouvernance urbaine: deux thématiques fondamentales et indissociables dans le cadre de la reconstruction de la ville de Port-au-Prince. 2012.

ONU. Declaração de Istambul sobre assentamentos humanos, 1996. Disponível em https://www.google.com.br/?gws. Acesso em 30 de jul. de 2018.

Declaração Universal dos Direitos Humanos, 1948. Disponível em:

http://www.onu.org.br/img/2014/09/DUDH.pdf .Acesso em: 22 de ago. de 2018.

PRÉVIL, C. Chronique d'une espérance. L'hebdo de Georges Anglade (2007-

2008), Port-au-Prince, L'Imprimeur II, Collection Livres en folie, 2008.

Pierre-Etienne, S. Haïti, la république dominicaine et Cuba: état, économie et société (1492-2009), Paris, L'Harmattan, 2012.

PEAN, L. Haïti, économie politique de la corruption. Tome I, Paris, Maisonneuve et Larose, 2003.

Haïti, économie politique de la corruption: L'État marron (1871-1915).

Tome II, Paris, Maisonneuve et Larose, 2005.

Haïti, économie politique de la corruption: Le saccage (1915-1956). Tome

III, Paris, Maisonneuve et Larose, 2006

. Haïti, économie politique de la corruption: L'ensauvagement macoute et ses conséquences (1957-1990). Tome IV, Paris, Maisonneuve et Larose, 2007.

PIERRE, J. A. Sociologie Économique de la corruption vers une étude de l'implémentation des politiques publiques de lutte contre la corruption en Haïti. Thèse Doctorat en Sociologie, soutenue à Université de sorbonne. Paris. 2014. 
RAFESTIN, C. Por uma Geografia do Poder. Tradução de Maria Cecília França. São Paulo. Ática, 1993.

SANTOS, M. Espaço e Sociedade. Petrópolis: Vozes, 1979.

- O Espaço Dividido. Os Dois Circuitos da Economia Urbana dos Países Subdesenvolvidos. $2^{\text {a }}$ ed. São Paulo: Edusp, 2008.

. Por uma Geografia Nova. São Paulo: Hucitec, Edusp, 1978.

. Pensando o espaço do homem. São Paulo: Hucitec, 1982.

. Espaço e método. São Paulo: Nobel, 1985.

. A Natureza do Espaço. São Paulo: Hucitec, 1996.

. O espaço do cidadão. São Paulo: Nobel, 2000.

. A urbanização brasileira. 5. ed. São Paulo: Edusp, 2005.

SCARLATO, F, C. População e Urbanização brasileira. In: Jurandyr L. Sanches Ross (orgs) Geografia do Brasil. -5. ed. ver e ampl.-São Paulo: Edusp, 2005.

SEITENFUS, R. «Haïti est la preuve de leéchec de l'eaide internationale», 2010.

Disponível em: http://www.letemps.ch/Page/Uuid/2a1b8ad0-0bb8-11e0- 91f4 Acesso em: 20 de maio de 2019.

QUIJANO, A. Imperialismo y Marginalidad en América Latina. Lima: Mosca Azul, 1977.

Modernidad, identidad y utopía en América Latina (Lima: Ediciones Sociedad y Política), 1988.

TROUILLOT, M, R. Haiti state against nation. The origins and legacy of duvalierism,

New York, Monthly Review Press, 1990.

THOMPSON, E, The Plantation. Chicago. 1935.

THÉOPHILE R, L'organisation interne et les caractéristiques socio-économiques et physiques des zones marginales de Port-au-Prince. Port-au-Prince, 1990. 80 p.

WARGNY, C. Haiti n'existe pas: 1804-2004 deux cents ans de solitude. Éditions Autrement, Paris, 2004. 


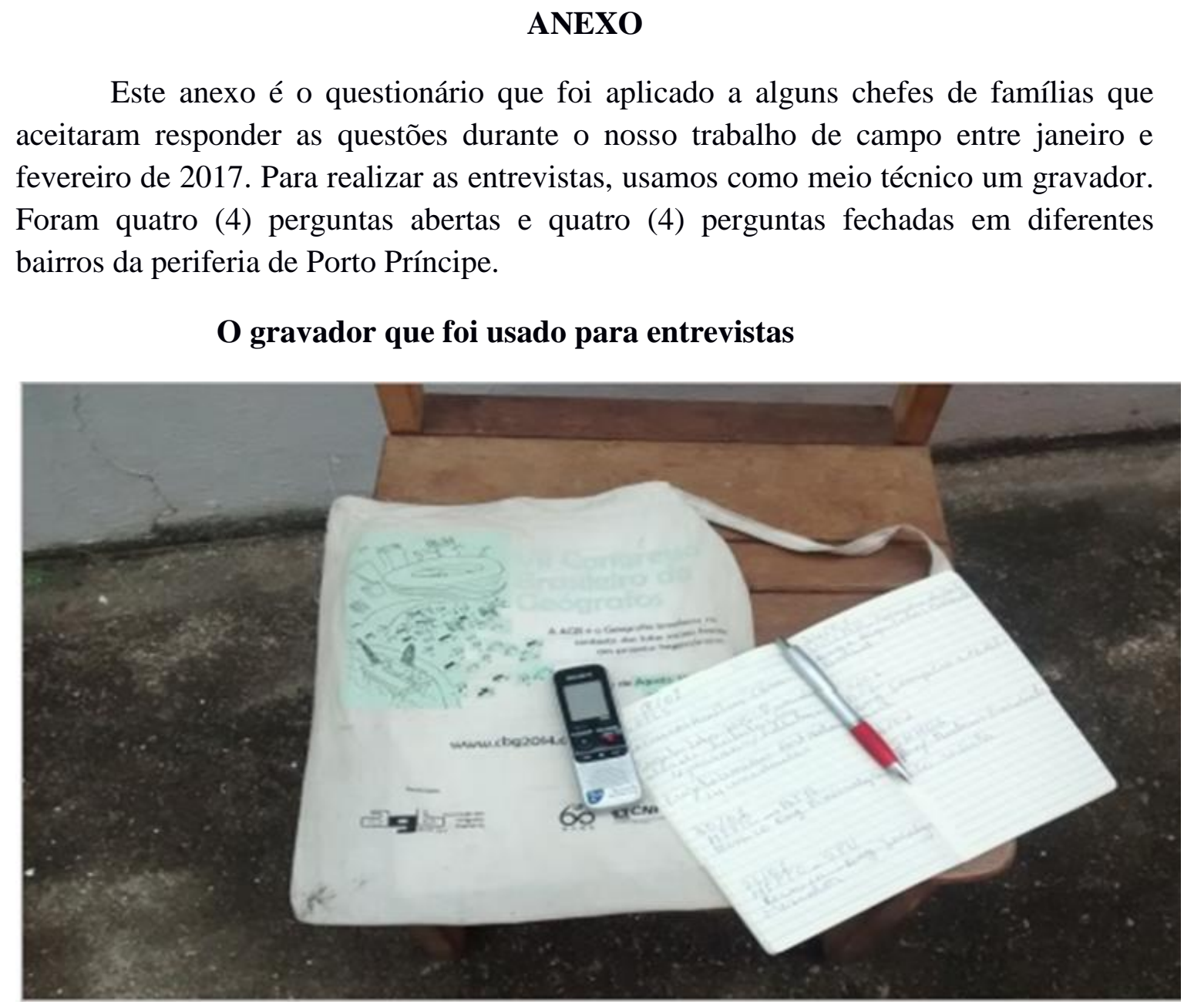

Fonte: fotografado pelo autor, 2017.

\section{Respostas às perguntas abertas}

\section{Respostas de Sergo}

1.Por que escolheu morar aqui na periferia sul de Porto Príncipe?

R: Escolhi morar aqui no alto Carrefour-Feuilles porque minhas condições econômicas não me permitiram morar num bairro, onde o acesso aos serviços básicos tais como: uma moradia decente, água, coleta de lixo, saneamento básico, entre outros.

2. Na sua opinião, quais são as principais dificuldades encontradas para morar aqui?

R: As principais dificuldades encontradas para morar neste bairro, é o acesso aos serviços básicos, principalmente água. Este bem comum que temos que andar por cerca de $1 \mathrm{~km}$ e meio para buscar água usando balde. Após água deve ser levada em cima de cabeça para quem que mora no alto Carrefour-Feuilles e que não tem uma camionete. Além disso, a falta de eletricidade com interrupção de eletricidade por período entre 5 horas a 10 horas durante o dia. 
3.O que mudou em suas condições de habitação antes e no pós-terremoto de 2010 ?

R: Após o terremoto minhas condições de habitação pioraram, devido à destruição da minha casa que trabalhei durante 30 anos para construí-la, e eu tive que passar meses vivendo em barracos. Isso foi a realidade para muitos moradores aqui no bairro, graças a Deus não tive ninguém que morreu na minha família.

4.Quais foram suas expectativas quando migrou para a cidade de Porto Príncipe?

R: Não migrei para Porto Príncipe, pois nasci e cresci aqui em Carrefour-feuilles, mas meus pais são do Departamento do Sudeste que vieram em Porto Príncipe durante o governo de Paul Magloire na década de 1950.

\section{Respostas de Marie}

1. Por que escolheu morar aqui na periferia sul de Porto Príncipe?

R: Não escolhi morar aqui, moro neste bairro devido as minhas condições econômicas, aqui falta tudo no que diz respeito às necessidades sociais, tais como água, eletricidade, entre outros, ainda tenho medo de deslizamento de terra nos períodos chuvosos.

2. Na sua opinião, quais são as principais dificuldades encontradas para morar aqui?

$\mathrm{R}$ : Na minha opinião as principais dificuldades encontradas para morar aqui em Carrefour-feilles são os serviços socais básicos sobretudo, o acesso à água que é um pouco longe daqui, no entanto, a água é uma necessidade vital pelos diversos usos.

3. O que mudou em suas condições de habitação antes e no pós-terremoto de 2010 ?

R: Não mudou nada nas minhas condições de habitação, pois, graças a Deus tive sorte na medida em que, a minha casa não foi destruída pelo terremoto e foi avaliada pelos técnicos do Ministério das Obras Públicas, Transportes e comunicações (MTPTC). Agora, só preciso arrumar um emprego para colocar um andar em cima dela.

4. Quais foram suas expectativas quando migrou para a cidade de Porto Príncipe?

R: Não tinha perspectivas porque, naquela época, saí no Departamento do Sul com meus pais, ainda eu era adolescente para vir estudar aqui em Porto Príncipe.

\section{Respostas de Adlet}

1. Por que escolheu morar aqui na periferia sul de Porto Príncipe?

R: Escolhi morar aqui porque desde que deixei o Departamento do Nordeste e entrei em Porto Príncipe nos anos de 1970, durante o governo de Papa Doc (ditador François Duvalier), meus parentes moravam aqui. Assim, após muito tempo de trabalho consegui construir minha própria casa; infelizmente o terremoto de janeiro danificou uma grande parte que não precisa ser demolida segundo o (MTPTC, 2011) e, ainda hoje, não tenho condições econômicas para fazer as reparações necessárias. 
2. Na sua opinião, quais são as principais dificuldades encontradas para morar aqui?

$\mathrm{R}$ : Na minha opinião, as principais dificuldades encontradas aqui são, o problema de acesso aos serviços básicos (saneamento, água potável, eletricidade); o serviço de coleta de lixo; o tratamento de esgoto. Além disso, a falta de infraestruturas; que gera tráfego para automóveis que complica enormemente o trânsito de pessoas; presença de mercado nas ruas do bairro entre outros.

3. O que mudou em suas condições de habitação antes e no pós-terremoto de 2010 ?

R: Bom, minhas condições de habitação eram bem melhores antes do terremoto de 12 de janeiro de 2010. Como já disse para você que a minha casa foi danificada e até o presente momento que estou te falando não tenho condições econômicas para comprar os materiais e pagar um pedreiro para fazer as reparações, mas, Deus sabe tudo.

4. Quais foram suas expectativas quando migrou para a cidade de Porto Príncipe?

R: Quando migrei para cidade de Porto Príncipe, especificamente aqui em Fort National, minhas expectativas eram primeiramente estudar e depois trabalhar na cidade com o propósito de construir uma vida melhor. Só que não aconteceu como eu pensava porque meus estudos foram interrompidos devido às responsabilidades familiares, a situação política, socioeconômica do Haiti, nos últimos 30 anos, entre outros.

\section{Resposta de Walner}

1. Por que escolheu morar aqui na periferia norte de Porto Príncipe?

R: A opção de morar aqui neste bairro foi da minha esposa que já tinha comprado a casa, em seguida fizemos uma grande reparação nela. Assim, desde 2006, estamos morando aqui. Posso dizer que graças a Deus ela não foi destruída pelo terremoto de 2010, no entanto, uma grande parte dela foi danificada.

2. Na sua opinião, quais são as principais dificuldades encontradas para morar aqui?

R: Na minha opinião, os principais problemas encontrados para morar aqui são o acesso aos serviços sociais básicos, como água potável, eletricidade, saneamento básico, acumulação de lixo nos cantos de ruas. Estes para mim, os problemas crônicos não apenas aqui em Fort National, mas, em quase toda região metropolitana de Porto Príncipe.

3. O que mudou em suas condições de habitação antes e no pós-terremoto de 2010 ?

$\mathrm{R}$ : A respeito das minhas condições de moradia, antes do terremoto morava melhor devido ao aumento da família e depois do terremoto tinha perdido meu emprego, portanto, estou sem condições econômicas para acrescentar a casa, para que a família tenha morada decente.

4. Quais foram suas expectativas quando migrou para a cidade de Porto Príncipe? 
R: Migrei em Porto Príncipe por motivos de estudos e após era ter um bom emprego só que não aconteceu como eu imaginava, mas, Deus sabe tudo.

\section{Respostas de Cénatus}

1. Por que escolheu morar aqui na periferia norte de Porto Príncipe?

R: Escolhi morar aqui porque a casa era dos meus pais; eles compraram a terra e construí a casa nos anos de 1960, assim quando entrei em Porto Príncipe nos anos na década de 1970.Vim morar com eles e após o falecimento deles a casa ficou para mim, mas, se eu tiver condições econômicas, além de vender a casa para ir morar no outro bairro com menos problemas eu faria, pois, aqui é complicado em todos os sentidos.

2.Na sua opinião, quais são as principais dificuldades encontradas para morar aqui?

R: A meu ver, as principais dificuldades encontradas para morar aqui são acumulação de lixos nos diferentes canais que atravessaram o bairro, salubridade, inundação nos períodos chuvosos, falta de saneamento básico, violência entre grupos armados que são manipulados pelos políticos que fazem com que, no momento de crise política eu e minha família ficamos com muito medo.

3. O que mudou em suas condições de habitação antes e no pós-terremoto de 2010?

R: Minha condição de habitação não mudou muito após o terremoto de 12 de janeiro de 2010. Contrariamente com outras pessoas, graças a Deus minha casa não foi destruída pelo terremoto; porém, em outubro de 2016, minha casa foi inundada perdi tudo que tinha e uma parte da casa desabou. Nesse sentido, posso dizer que minha situação de habitação piorou não por causa do (goudou goudou, nome popular do terremoto em Crioulo haitiano) mas, sim devido à inundação que conheceu esta parte de Porto Príncipe onde moro.

4: Quais foram suas expectativas quando migrou para a cidade de Porto Príncipe?

R: Quando migrei para cidade de Porto Príncipe eu era adolescente. Então, minhas expectativas eram continuar meus estudos, após conseguir um trabalho em Porto Príncipe e criar uma família, mas não tive a oportunidade de chegar longe quanto ao meus estudos devido à incapacidade dos meus pais de pagar uma boa escola para mim e de cuidar uma família 7 pessoas naquela época.

\section{Respostas de Jacqueline}

1. Por que escolheu morar aqui na periferia norte de Porto Príncipe?

R: Escolhi morar aqui na Cidade de Deus, porque a casa que aluguei antes do terremoto foi destruída pelo desastre de janeiro de 2010. Após dois anos, morando numa barraca em Champs de Mars (a maior praça pública no centro da cidade), eu estava buscando onde morar assim; vim morar na cidade de Deus, mas, a escolha foi feita em razão das 
minhas condições econômicas, por que aqui neste bairro a situação de vida é muito difícil.

2. Na sua opinião, quais são as principais dificuldades encontradas para morar aqui?

R: Pelo tempo que moro neste bairro, as principais dificuldades encontradas para morar aqui neste bairro são: a inundação, os canais cheios de lixo, insegurança, conflito entre grupos armados, interrupção da eletricidade entre outros: então, aqui não era para morar seres humanos e governos não tem nenhum um plano para nos tira nesta condição, eles só vieram por aqui quando tiver campanha eleitoral e quando houver inundação com muitos mortos, para fazer todas promessas.

3. O que mudou em suas condições de habitação antes e no pós-terremoto de 2010 ?

R: Bom, apesar de que nunca tive minha casa própria, posso dizer que a minha condição de habitação piorou após 2010. Como já contei, após o terremoto tive que passa 2 anos em baixo de uma barraca em Champs de Mars, junto com meu marido e meus três filhos, isso foi muito horrível, mas, Deus sabe tudo. Agora, se eu tiver condições econômicas de alugar uma casa melhor num outro bairro, eu alugaria, devido a todos os problemas que existem aqui neste bairro.

4. Quais foram suas expectativas quando migrou para a cidade de Porto Príncipe?

R: Quando sai no Departamento da Grand'Anse, nos anos de 1980, para cidade de Porto Príncipe, minhas expectativas eram fazer comércio (ambulante) no centro da cidade, criar meus filhos e mandar eles numa boa escola para que eles posaram ingressar na universidade que eu não tive sorte de fazer. Ou seja, em busca de uma vida melhor.

\section{Respostas de Morpeau}

1. Por que escolheu morar aqui periferia leste de Porto Príncipe?

R: A escolha de morar aqui em Turgeau é da minha família que morava no centro na década de 60, para nossa segurança eles vieram de morar neste bairro no final dos anos de 1970, durante o governo do ditador François Duvalier, é assim, que tive oportunidade de comprar um pedaço de terra e construir a minha casa.

2. Na sua opinião, quais são as principais dificuldades encontradas para morar aqui?

R: Desde que vim morar aqui não encontrei nenhuma dificuldade, somente nos períodos chuvosos com ventos fortes porque podem cair arvores em cima das casas, de carros, corte de elétrica, as vezes demorar um pouco para reconcertar a rede elétrica. Além desses problemas, é tranquilo morar aqui neste bairro.

3. O que mudou em suas condições de habitação antes e no pós-terremoto de 2010 ?

R: Em relação as minhas condições de habitação, tanto antes como depois do terremoto de 2010, não mudou na medida em que tive sorte, quando o terremoto ocorreu no dia 
12 de janeiro a minha casa não teve nenhum problema, porém, o muro em torno da casa desabou, aí tive que montar o muro de novo.

4. Quais foram suas expectativas quando migrou para a cidade de Porto Príncipe?

R: Não tinha expectativas porque nasci e cresci em Porto Príncipe, e eu vi tudo que aconteceu e vem acontecendo em Porto Príncipe, desde a queda do poder dos Duvalier em 1986, que deu o início ao colapso da sociedade haitiana, do ponto de vista político, econômica, social. Sem esquecer a vulnerabilidade do Haiti diante aos fenômenos naturais, tais como: terremotos, furacões entre outros.

\section{Respostas de Sandra}

1. Por que escolheu morar aqui periferia leste de Porto Príncipe?

R: Escolhi morar em Turgeau porque durante a passagem do terremoto de 12 de janeiro de 2010, a casa onde morei foi destruída, assim encontrei esta casa aqui neste bairro que estou morando desde 2012. Mas, penso sair no ano que vem, pois, cada ano o preço de aluguel não para de aumentar devido, segundo o proprietário da casa, à procura de estrangeiros que trabalham nas Organizações Não Governamentais Internacionais (ONGI) e que têm condições de pagar em dólares americanos.

2. Na sua opinião, quais são as principais dificuldades encontradas para morar aqui?

R: Bom, na minha opinião, as principais dificuldades encontradas aqui é que não tem um circuito de transporte em comum que faz, por exemplo, a ligação entre Turgeau e o centro. Além disso, nos períodos chuvosos caem muitas árvores em cima de casas; a interrupção de energia elétrica devido à queda de arvores na maioria das vezes demora um tempo para que os técnicos da Eletricidade Do Haiti (EDH) vierem arrumar a rede elétrica.

3. O que mudou em suas condições de habitação antes e no pós-terremoto de 2010 ?

R: Em relação a minhas condições de habitação, se eu quiser fazer uma diferença, entre antes e depois do terremoto de 2010, eu diria que no pós-terremoto minha condição de habitação não mudou muito. No entanto, agora, estou pagando o aluguel no valor que é quase o dobro do que pagava antes da tragédia de 2010.

4. Quais foram suas expectativas quando migrou para a cidade de Porto Príncipe?

R: Nasci e fui criada aqui em Porto Príncipe, então, não posso fala nada a respeito. 


\section{Respostas relativas às perguntas fechadas}

Você sabia que uma moradia decente é um dos seus direitos garantidos pela Constituição Haitiana de 1987 ?

Sim: 14

Não: 22

Na casa onde mora, você é o proprietário?

Sim: 14

Não: 16

A gestão do governo (2011-2016), em relação à política habitacional foi:

Ótima: 1

Boa: 4

Péssima: 23

Qual é seu grau de satisfação em relação aos serviços públicos (infraestruturas, coleta de lixo, tratamento de esgoto entre outros) prestados pela Prefeitura Municipal de Porto Príncipe?

Muito satisfeito: 0

Satisfeito: 2

Insatisfeito: 16

Fonte: Elaborado pelo autor baseado nos dados coletados em trabalho de campo, 2017. 